\title{
Representing Justice:
}

Architecture and the New Zealand Supreme Court

by

Matthew Thomas Watson

A thesis

submitted to the Victoria University of Wellington

in fulfilment of the requirements for the degree of

Master of Architecture

Victoria University of Wellington 
Justice is an abstract ideal. To administer it is a concrete problem.

William S. Fort, Facilities for the Administration of Justice 


\begin{abstract}
This thesis investigates the architectural significance of a recent exemplar of judicial architecture, the New Zealand Supreme Court complex (2010), in order to assess the complex's design as an embodiment of judicial aspirations. The underlying assumption of this study (based on the works of Goodsell, Edelman, Garapon and others) is that the architecture of the Supreme Court complex legibly responds to its layered (but not always publicly accessible) briefing process, a process which expresses the aspirations of the New Zealand justice system at the beginning of the $21^{\text {st }}$ century. By way of background, the study describes the history of the New Zealand judicial system, outlining the evolution of New Zealand's court hierarchy (including the genesis of the Supreme Court as New Zealand's court of final appeal) and of New Zealand's judicial architecture. The role of the Supreme Court within New Zealand's constitutional and legal framework is also examined, particularly in relation to recognising and supporting the rule of law and Treaty of Waitangi in New Zealand jurisprudence. The judicial aspirations of the Supreme Court are evinced through analyses of the Supreme Court Act 2003 and the Supreme Court project's briefing process. These aspirations are coupled with an analysis of the Supreme Court complex's built form to enable an assessment of architectural expressions in the Supreme Court complex of concepts of judicial independence, history and tradition; the indigenous nature of the Supreme Court; and the Court's role in upholding the rule of law and sovereignty of Parliament. The outcome of this research is a greater understanding of the function of the Supreme Court complex as a symbol of the judicial values and aspirations for New Zealand's justice system in the early $21^{\text {st }}$ century. The significant findings of this study are that the Supreme Court
\end{abstract}


complex is legibly successful in terms of its architectural engagement with New Zealand's judicial heritage and the contemporary approaches of openness, transparency and access in the judicial system, but that the architecture the Supreme Court fails to appropriately engage with the significance of the on-going $\mathrm{M}$ ori-Crown constitutional relationship embodied in the Treaty of Waitangi, evincing a disconnect between the judicial aspirations expressed at the establishment of the institution and those expressed in the Court's built form. It is suggested that this discrepancy highlights a layering of aspirations that occurred in the Supreme Court complex's briefing process. 


\section{Acknowledgements}

Acknowledgements and thanks are due to-

My supervisor, Dr Robin Skinner, for his guidance, insight, patience and humour, and for applying just the right amount of pressure at just the right times;

Roy Wilson, principal of Warren and Mahoney, for his invaluable assistance in providing me insight into the Supreme Court project;

Staff at the Ministry of Justice, particularly Lois Ward, Andrew Hampton and Joanne Jeppesen, for graciously dealing with my numerous requests for information and assistance;

Sir Kenneth Keith, former judge of the Supreme Court, Chris Cochran, conservation architect and advisor on the Supreme Court project, and Gordon Thatcher, Registrar of the Supreme Court, for their advice and assistance;

Paul McCredie, for permitting my use of his superb collection of Supreme Court complex photographs; and

My family, friends and colleagues, and the staff of Victoria University of Wellington Faculty of Architecture and Design, for all their support throughout this long process. 


\begin{tabular}{ll} 
& \multicolumn{1}{c}{ Abbreviations } \\
The following abbreviations are used in passing throughout thi & Ministerial Advisory Group \\
MAG & Ministry of Justice, Wellington, New Zealand \\
MoJ & New Zealand Historic Places Trust \\
NZHPT & Old High Court building \\
OHCB & Project Steering Group \\
PSG & Supreme Court Act 2003 \\
SCA & Warren and Mahoney, Architects, New Zealand \\
&
\end{tabular}




\section{Contents}

$\begin{array}{ll}\text { Abstract } & 5\end{array}$

$\begin{array}{lr}\text { Acknowledgements } & 7\end{array}$

$\begin{array}{lr}\text { Abbreviations } & 8\end{array}$

$\begin{array}{lr}\text { Contents } & 9\end{array}$

$\begin{array}{ll}\text { Illustrations } & 11\end{array}$

$\begin{array}{ll}\text { I. Introduction } & 15\end{array}$

$\begin{array}{lr}\text { A Note on Legal Terminology } & 17\end{array}$

$\begin{array}{lr}\text { Research Design } & 19\end{array}$

$\begin{array}{ll}\text { Thesis Structure } & 20\end{array}$

$\begin{array}{lr}\text { II. The New Zealand Judicial System } & 23\end{array}$

$\begin{array}{lr}\text { The New Zealand Court System } & 23\end{array}$

New Zealand Judicial Architecture $\quad 49$

$\begin{array}{lr}\text { III. Expressive Meaning in Judicial Architecture } & 71\end{array}$

$\begin{array}{lr}\text { IV. Briefing the Supreme Court Project } & 83\end{array}$

The Judicial Aspirations of the Supreme Court 83

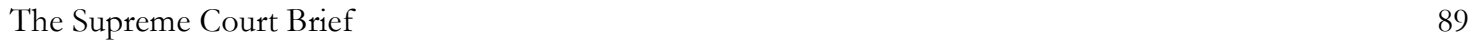

$\begin{array}{lr}\text { V. The Architecture of the Supreme Court Complex } & 97\end{array}$

$\begin{array}{ll}\text { The Supreme Court Building } & 97\end{array}$

$\begin{array}{lr}\text { The Old High Court Building } & 125\end{array}$ 
An Indigenous Court

VII. Conclusion

Error! Bookmark not defined.

Appendix IV Supreme Court Complex - Architectural Drawings

Appendix IV Supreme Court Complex - Selected Credits and Awards

Bibliography 8 4 (1) 


\section{Illustrations}

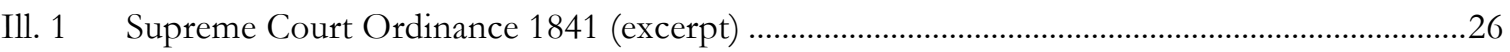

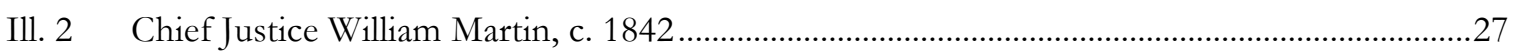

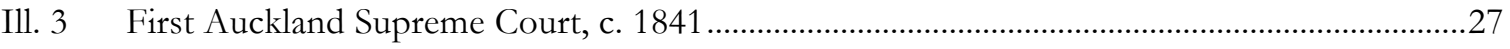

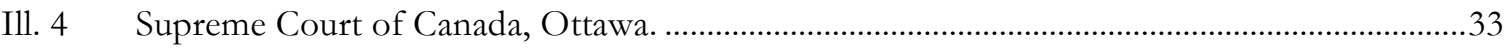

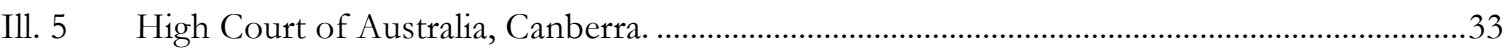

Ill. 6 The New Zealand Court Hierarchy since 1 July 2004 ................................................................

Ill. $7 \quad$ Former Wellington Supreme Court, c. 1865 ……………………….........................................

Ill. $8 \quad$ Former Dunedin Supreme Court, c. 1850 .............................................................................

Ill. 9 Former Queenstown Courthouse and Library …………………………………........................52

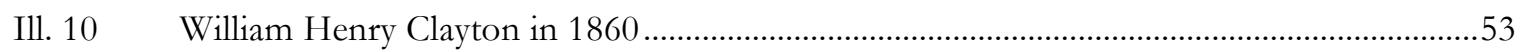

Ill. 11 Former Coromandel Courthouse and Post Office ……………………….............................53

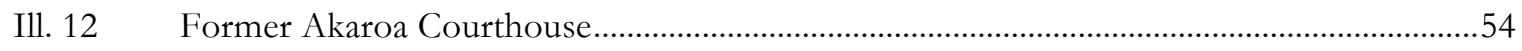

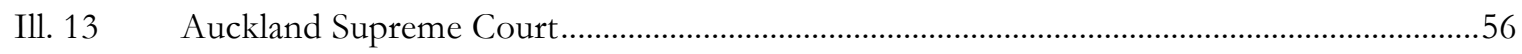

Ill. $14 \quad$ W. H. Clayton’s Government Building ..................................................................................

Ill. 15 P. F. M. Burrow's Wellington Supreme Court...........................................................................

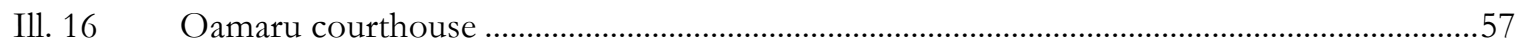

Ill. 17 Dunedin courthouse ……………………………………………………………….....

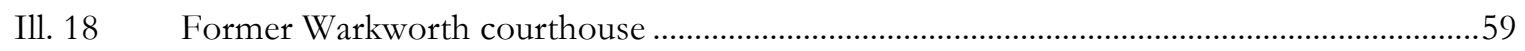

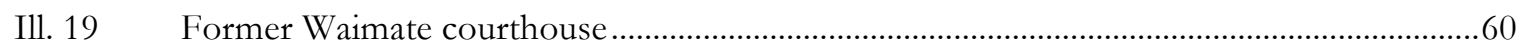

Ill. $20 \quad$ Former Hamilton Courthouse

Ill. $21 \quad$ John Campbell ........................................................................................................... 62

Ill. 22 Former Auckland Magistrates Court........................................................................................ 62

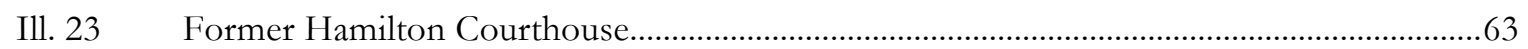

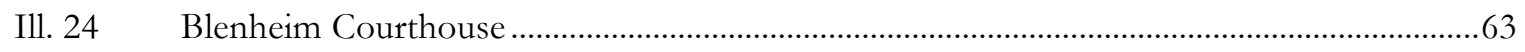

Ill. $25 \quad$ Nelson Courthouse (original) ……………………………………………………….....6 
Ill. 26 Christchurch Courthouse

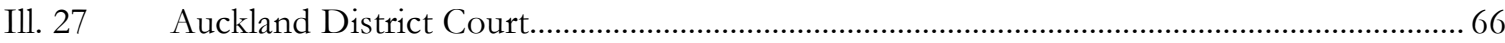

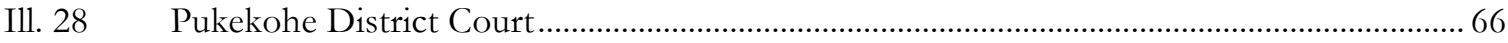

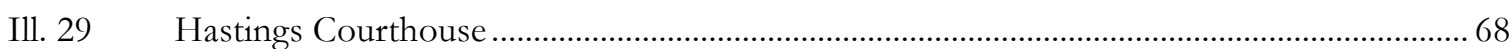

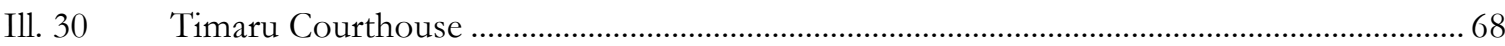

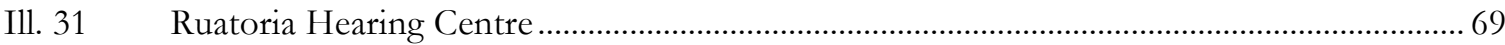

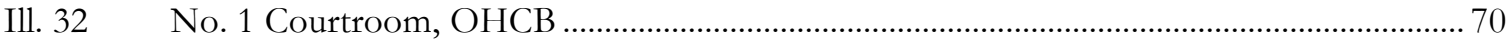

Ill. 33 Courtroom, Timaru Courthouse ….................................................................................... 70

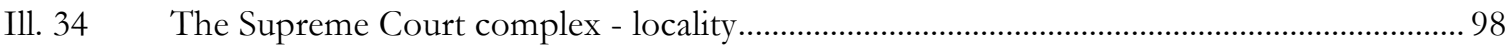

Ill. 35 The Supreme Court complex - aerial view ...................................................................... 98

Ill. 36 Supreme Court viewed from intersection of Lambton Quay and Whitmore Street......... 101

Ill. 37 Supreme Court complex with Stout and Ballance Street buildings beyond ...................... 101

Ill. 38 Supreme Court, bronze screen and reflecting pool .......................................................... 104

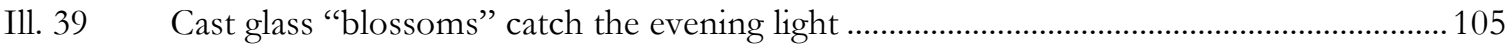

Ill. $40 \quad$ Supreme Court entrance on Lambton Quay ................................................................... 106

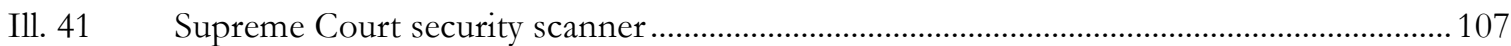

Ill. 42 Concierge's desk in the Supreme Court lobby ….............................................................. 108

Ill. 43 Exterior of the Supreme Court courtroom........................................................................ 109

Ill. 44 Information screens in the Supreme Court lobby …....................................................... 109

Ill. 45 Supreme Court library viewed from the lobby............................................................. 110

Ill. $46 \quad$ Supreme Court Registry counter ..................................................................................... 110

Ill. $47 \quad$ Supreme Court spiral staircase …................................................................................. 111

Ill. $48 \quad$ Visual access from lobby to Supreme Court bench ........................................................ 112

Ill. 49 An entry to the Supreme Court courtroom ................................................................. 113

Ill. $50 \quad$ Beech panels lining the Supreme Court courtroom …...................................................... 114

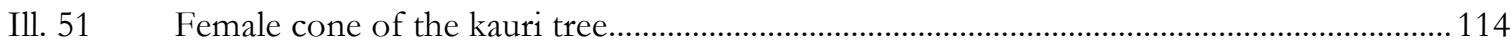


Ill. 52 Moiré effect in brickwork.

Ill. $53 \quad$ Courtroom wall penetrations (interior) …........................................................................116

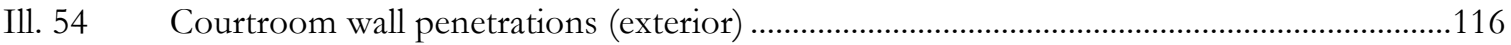

Ill. 55 Courtroom skylight with louvres closed behind the acoustic reflector .............................117

Ill. 56 Tukutuku panel-inspired acoustic screens .....................................................................118

Ill. 57 Curved bench, New Zealand coat of arms, and glass cabinets ........................................120

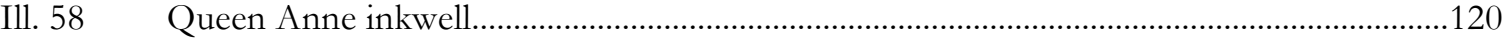

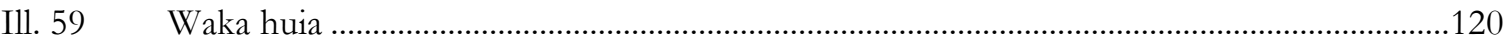

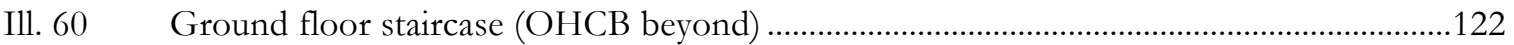

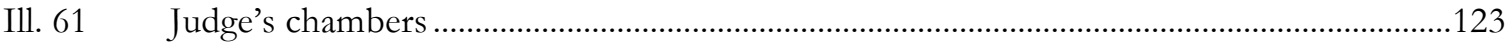

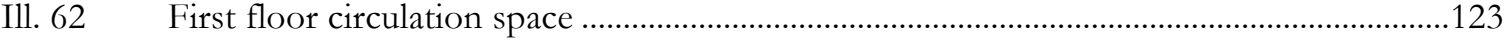

Ill. 63 Light reflected off the courtroom into the first floor circulation space ............................124

Ill. 64 Access between the Supreme Court and OHCB (former judge's chamber) .....................124

Ill. 65 OHCB (left) viewed from Thordon reclamation (c. 1881) ...............................................127

Ill. 66 OHCB lobby (entrance to No. 1 Courtroom on left) ….................................................131

Ill. $67 \quad$ Former Chief Justice’s chamber, OHCB ..........................................................................132

Ill. 68 Graffiti on press desk, No. 1 Courtroom, OHCB ...............................................................132

Ill. 69 Floor lights surrounding No. 1 Courtroom, OHCB .........................................................133

Ill. 70 Link between Supreme Court and OHCB, view from Supreme Court.............................134

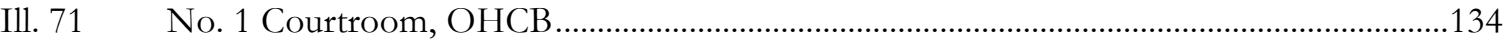

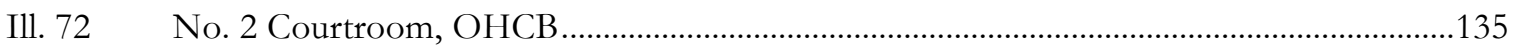

Ill. 73 HRH Prince William opening the New Zealand Supreme Court, 18 January 2010 ..........135

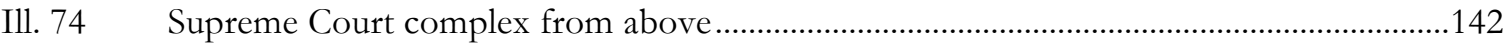

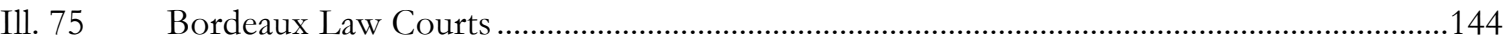

Ill. 76 Bordeaux Law Courts (transverse section) .......................................................................144

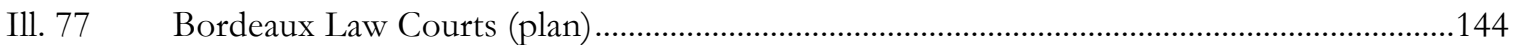


Ill. 78 Senior members of the judiciary (in red gowns) attend the opening of Parliament..........146

Ill. 79 Baldacchino with British Royal Arms, No. 1 Courtroom, OHCB .......................................148

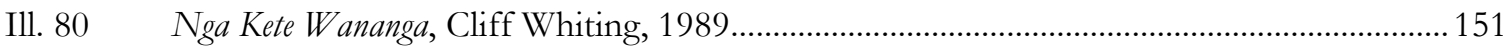

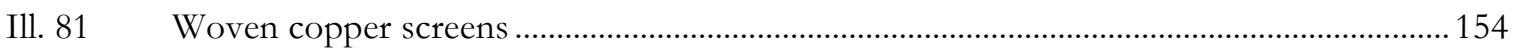

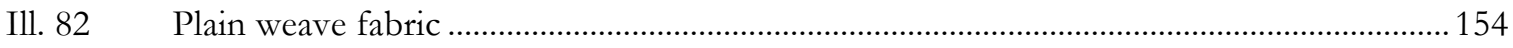

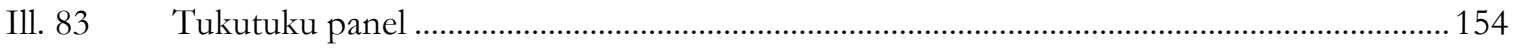

Ill. 84 Te Hono ki Hawaiki, Cliff Whiting, 1989............................................................................. 155

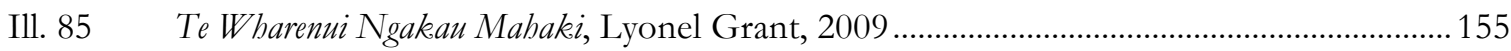

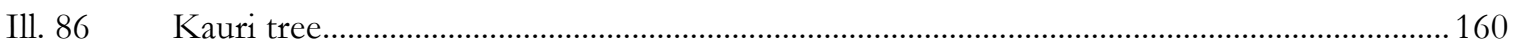

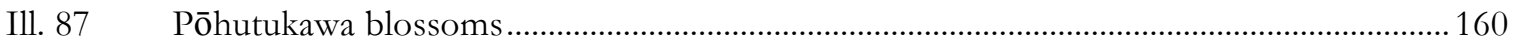

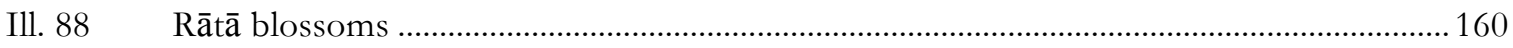

Ill. 89 Pōhutukawa planted on Whitmore Street frontage ................................................................ 161

Ill. 90 An advertisement relying on pōhutukawa's links with the New Zealand summer ...........162

Ill. 91 Pōhutukawa on a New Zealand postage stamp …………………………………………..... 162

Ill. 92 "Govt to Replace Privy Council with NZ Appointed Court" (16 April 2002)..............Error!

Bookmark not defined. 


\section{Introduction}

To address fundamental democratic principles, the citizen needs to be confident that the civic infrastructure contains an adequate courthouse where a dispute against another citizen may be taken for determination. The citizen also needs to know that there is a courthouse where that citizen's dispute with the government of the day, the state, may be addressed. In other words, court buildings are places where justice is played out. The courthouse lies at the heart of democratic government structures. [...] In democratic societies, courthouses are symbolic of the power of the courts and the rule of law over all citizens and, significantly, governments. ${ }^{1}$

As the Hon. Marilyn Warren AC, Chief Justice of the Supreme Court of Victoria, impassionedly identifies in the above quotation, courthouses are essential infrastructure in societies that embrace democracy and the rule of law. They are sites of great constitutional and social importance, manifestations of the judicial branch of our system of government, and symbols of the value and importance in our societies of that intangible ideal we call "Justice." Community faith in the justice system is essential to the operation of the rule of law; as one New Zealand High Court judge has stated: "Lawyers and judges know that the law only works for the community because most of the community obeys the law, and traditionally, a courthouse had been built as a statement of the importance of the law." ${ }^{2}$ It is judicial architecture's fundamental role in enabling and supporting the rituals of public justice

\footnotetext{
${ }^{1}$ Marilyn Warren, The Politics of Court Architecture. Paper presented at the Third Justice Environments Conference, University of Western Sydney, Sydney, Australia, May 2010. http://www.uws.edu.au/_data/assets/pdf_file/0010/138295/The_Politics_of_Court_Architecture.pdf.

2 Clare Allison, "High Court sits for last time in old building" The Timaru Herald (8 April 2009). http://www.stuff.co.nz/timaru-herald/news/2322073/High-Court-sits-for-last-time-in-old-building
} 
that makes the investigation and understanding of the courthouse typology so important. As Chief Justice Warren identifies above, courthouses are a requisite component of a justice system. Justice systems are constantly evolving, motivated by political, social, cultural, economic, and judicial aspirations to develop in a certain direction, to take on a certain form, or evolve at a certain rate. Judicial architecture expresses the judicial aspirations of a justice system in order that those aspirations are communicated to the public at large. In this way judicial architecture plays a significant role in influencing public perceptions of (and confidence in) the justice system.

The Supreme Court Act 2003 (SCA) determined that the court of final appeal should be a New Zealand institution situated in New Zealand. Internationally New Zealand is thus in the very rare position of having recently instituted a Supreme Court as the court of final appeal within an existing judicial hierarchy. Moreover, this evolution of New Zealand's judicial system has taken place within a post-colonial and bicultural social, political and legal context and with the benefit of substantial political and public debate concerning the desirability and constitutional, legal, and political ramifications of establishing a new court. Prominently sited in Wellington, the Warren and Mahoney (WaM) designed Supreme Court complex is singular, and not without controversy. In light of Chief Justice Warren's comment above, the Supreme Court courthouse is necessarily a statement of the importance of the law. In addition, it is an expression of the importance of the role of the court to the state, to the judiciary, and to the community at large. This situation provides a unique opportunity to assess an important work of judicial architecture against the express aspirations of the judicial system it represents and contains, thus providing a better understanding of how judicial architecture is mobilised to such ends. This is possible as the 
aspirations of the institution which informed the design are enshrined in the Court's constituting legislation, supplemented by formal and verbal briefings, and responsive critique from within the architects' practice and the project's judicial and political advisors.

The aim of this study is to assess the design of the New Zealand Supreme Court complex as the embodiment of judicial aspirations. The study's underlying assumption is that the architecture of the Supreme Court complex legibly responds to its layered (but not always publicly accessible) briefing process, a process which expresses the aspirations of the New Zealand justice system at the beginning of the $21^{\text {st }}$ century. This study analyses the New Zealand Supreme Court complex through legislation, briefing documents, archival research, interviews and built form in order to assess the judicial aspirations legible in the design.

\section{A Note on Legal Terminology}

As readers may not have a detailed understanding of the New Zealand judicial system, an explanation some of the legal terms used throughout this thesis is provided.

This study engages with judicial architecture, that is, the built environment that supports the functioning of the judicial system, particularly courthouses and their courtrooms. A courthouse is a building which houses one or more courtrooms and judges' chambers, and administrative and support functions. Within a courthouse, a courtroom is the physical space in which judges hear evidence and legal arguments and deliver judgments, while a judge's chamber is her or his private office. This study is concerned particularly with judicial aspirations expressed in the architecture of the New Zealand Supreme Court complex, which comprises the Supreme Court building (i.e. the Supreme Court courthouse) and its ancillary building, the restored Old High Court building (OHCB) (i.e. the former Wellington High 
Court courthouse), as an example of judicial architecture within the context of the New Zealand judicial system. Judicial aspirations are aspirations promoted by those responsible for the maintenance of the judicial system (including the judiciary, the executive, Parliament, and legal community) for that system. The legal or justice system is the broad system of law making and enforcement within a jurisdiction, of which the judicial system is a part, comprising the judiciary and hierarchy of courts that is empowered (inherently or by statute) to justiciate on legal matters. A statute or Act is a law enacted by Parliament, as opposed to the common law, which is that body of law declared by the courts in the course of deciding disputes before them. Common law jurisdictions such as the United Kingdom, Australia, Canada, the United States and New Zealand all have the common law as a part of their legal systems (via their common English legal heritage); civil law jurisdictions such as Germany and France do not. The judiciary is the branch of government responsible for administering justice and is made up of judges appointed by the Queen on the recommendation of the Attorney-General. The Chief Justice is the head of the judiciary (and the most senior of the New Zealand Supreme Court judges). The other two branches of government are the legislature (Parliament) and the executive, being the monarch and ministers of the Crown in respect of New Zealand, commonly called the government. At the apex of the New Zealand court hierarchy is the Supreme Court (M ori: Te K ti Matua o Aotearoa), the court of final appeal. The Supreme Court only hears appeals from decisions of the Court of Appeal to which it has granted its leave to appeal. A court of final appeal is the final forum for legal redress within a judicial system. The Privy Council (formally: the Judicial Committee of the Privy Council, established pursuant to the Judicial Committee Act 1833 (UK) to hear legal petitions to the Monarch in Council) served as New Zealand's court of final appeal from the assumption of sovereignty 
over New Zealand by the British Crown until 1 July 2004, when (pursuant to the SCA) the Supreme Court replaced the Privy Council as New Zealand's court of final appeal.

\section{Research Design}

As stated above, the aim of this study is to assess the design of the New Zealand Supreme Court complex as an embodiment of judicial aspirations. This aim is based on the assumption that, in response to its briefing process, the architecture of the Supreme Court complex is a legible expression of the aspirations of the New Zealand judicial system at the beginning of the $21^{\text {st }}$ century, an assumption based in turn on the theories of Goodsell, Edelman, Lasswell, Arnheim and Gusfield. Accordingly, this study's predominant mode of investigation is a qualitative case study of the Court's architecture. The Supreme Court complex provides a valuable opportunity to evaluate this study's underlying assumption given the clear expression of the judicial aspirations for the Court within the SCA, the court's recent design and construction, and the accessibility of documentation and persons connected with the briefing and design of the project. This approach has been chosen due to the following salient characteristics of case studies:

1. A focus on a single case in its real-life context;

2. A capacity to explain (possibly multiple) causal links leading to a particular outcome;

3. The importance of theory development in the framing of the study;

4. The use of multiple sources of information in order to investigate the study's aim from a number of angles; and 
5. The ability for findings from the case study to inform a more generalised theoretical position. $^{3}$

The strategy employed in this research is qualitative in nature in that it seeks to interpret information gathered via the case study analysis together with archival documentation and interviews with key informants in order to assess the expression of judicial aspirations in the Court's architecture. However, given the nature and dynamic complexity of the institution and building studied, there are a number of limitations on the information available to the researcher and thus the extent to which conclusions can be drawn. For example, the impacts of personal design preferences, confidential security considerations, budgetary constraints, and matters of political expediency on the design of the Court were not able to be explored.

\section{Thesis Structure}

This thesis is divided into seven chapters.

\section{Chapter I - Introduction}

Chapter I introduces the problem of understanding judicial architecture's role in communicating the aspirations of the justice system. It identifies the New Zealand Supreme Court complex as the object of study, the assumption the aspirations of the New Zealand justice system at the beginning of the $21^{\text {st }}$ can be discerned through an analysis of the Supreme Court's briefing process and built form, and the design of the research undertaken.

\section{Chapter II - The New Zealand Judicial System}

Chapter II provides a brief history of the New Zealand judicial system, outlining New Zealand's judicial growth from a colony with one court and one judge to a fully independent

\footnotetext{
${ }^{3}$ See Linda Groat \& David Wang, Architectural Research Methods (New York: Wiley, 2002), 346.
} 
state with a mature and complex judicial system. The genesis of the Supreme Court as New Zealand's court of final appeal is described in detail before briefly examining the role of the Supreme Court in New Zealand's constitutional and legal framework, particularly in relation to the rule of law and Treaty of Waitangi/Te Tiriti o Waitangi in New Zealand jurisprudence.

\section{Chapter III - Expressive Meaning in Judicial Arcbitecture}

Chapter III introduces a number of concepts and theoretical positions relating to the study of judicial architecture which support the assumption that judicial architecture communicates judicial aspirations, including Goodsell's study of the social meaning of civic architecture, the work of Edelman, Lasswell, Arnheim and Gusfield on the use of symbolism in architecture, and studies on the role judicial architecture plays within the justice system by Garapon and the Law Reform Commission of Western Australia.

\section{Chapter IV - Briefing the Supreme Court Project}

The aim of Chapter IV is to assess the judicial aspirations of the Supreme Court as these are evinced through the SCA and the translation of the judicial aspirations expressed in that legislation into requirements within the Supreme Court complex's briefing documents.

\section{Chapter $V-$ The Architecture of the Supreme Court Complex}

Chapter V describes the architecture of the Supreme Court complex, drawing on the built form, archival research, and interviews with the complex's architects, Warren and Mahoney.

\section{Chapter VI - Representing Justice}

With the understanding of the role judicial architecture plays in communicating judicial aspirations garnered in Chapters II and III, drawing on the understanding of the Supreme Court's judicial aspirations expressed in the SCA and ancillary documentation gathered in 
Chapter IV, and utilising the Supreme Court complex case study described in Chapter V, Chapter VI of this thesis assesses the Supreme Court complex as embodiment of judicial aspirations. The works of a number of theorists assist in understanding the Supreme Court complex's architectural expressions of concepts of judicial independence, history and tradition; the indigenous nature of the Supreme Court; and the Court's role in upholding the rule of law and sovereignty of Parliament, including:

- Trapeznik \& McLean (in relation to built heritage conservation and national identity);

- Bell \& Lyall (landscape and national identity);

- Pati, Bose \& Zimring (“openness" in judicial architecture); and

- Barnstone and Resnik \& Curtis (both relating to transparency in architecture).

\section{Chapter VII - Conclusion}

Chapter VII concludes this work, drawing together the study's key findings and identifying areas warranting further investigation. 


\section{The New Zealand Judicial System}

In a study aiming to better understand how judicial aspirations are expressed in judicial architecture, some knowledge of the New Zealand judicial system and its architecture is necessary. The aim of Chapter II is to provide that background by sketching the history of New Zealand's judicial system and describing in detail the establishment of the Supreme Court as New Zealand's court of final appeal. A brief explanation of the role of the Supreme Court in New Zealand's constitutional and legal framework follows, particularly in relation to the rule of law and Treaty of Waitangi in New Zealand jurisprudence. A summary of the extant knowledge relating to judicial architecture in New Zealand is provided, illustrating the parallels between the development of the hierarchy of courts and the architecture of courthouses in New Zealand.

\section{The New Zealand Court System}

The model for New Zealand's judicial system was part of the system of government imported directly from England with the cession of sovereignty to the British Crown under the Treaty of Waitangi. The New Zealand judicial system is, for the most part, a creature of statute; although the High Court enjoys what is known as an inherent jurisdiction, the balance of the court hierarchy was created by Parliament to fulfil subservient and appellate roles within the constitutional separation of powers. ${ }^{4}$ While the British Crown initially sought to regulate and police the activities of European settlers from its New South Wales

\footnotetext{
${ }^{4}$ See the discussion regarding the constitutional role of the Supreme Court beginning on page 40.
} 
colony, the challenges of distance and time involved in doing so precluded the efficient administration of justice in New Zealand. As early as 1841 New Zealand's first permanent sitting court, the Supreme Court (forerunner to today's High Court), was created by colonial Government ordinance (Ill. 1) with Chief Justice William Martin being New Zealand's first (and at that time only) appointed judge (Ill. 2). A second judge, Mr Justice Henry Chapman, was appointed in 1844. The Supreme Court sat initially only in Auckland (Ill. 3), travelling to other settlements on circuit, but Supreme Courts were later established in other significant settler locales. From the very beginning, the Privy Council sat at the apex of our judicial system as court of final appeal to hear appeals from the Supreme Court.

Courts inferior to the Supreme Court were established by the colonial Legislative Council as they became necessary. The Court of Requests and Court of Petty Sessions were established in 1842 and a temporary Court of Appeals (comprising the Governor and members of the Executive Council sitting on an ad hoc basis) was established in 1846. Resident Magistrates' Courts (the forerunners to today's District Courts) were also established in 1846, being the first New Zealand courts with permanent seats in the nascent provinces. Within 20 years of the signing of the Treaty of Waitangi the legal landscape had evolved considerably. In 1858 the Court of Requests and Court of Petty Sessions were dissolved and replaced by District Courts pursuant to the District Courts Act 1858. A Court of Appeal comprised of Supreme Court judges replaced the Court of Appeals in 1862 but was still convened only when the case load required. Residents Magistrates' Courts became known simply as Magistrates’ Courts in 1893 and District Courts (which became redundant due to jurisdictional overlaps with the Supreme Court and Magistrates' Courts) were abolished in 1909. 
This court structure served New Zealand until 1957 when the Judicature Amendment Act 1957 created the first permanent Court of Appeal with dedicated judges independent of the Supreme Court. In 1978 the question of whether New Zealand ought to retain rights of appeal to the Privy Council was considered by a Royal Commission on the Courts ${ }^{5}$ which recommended that domestic reforms to the judicial system be made before any move to end those rights be initiated. The recommendations of the Royal Commission that the Magistrates' Courts be renamed District Courts and the Supreme Court be renamed the High Court were adopted by Parliament in $1980 .^{6}$ Over the years a number of other courts and tribunals were created to deal with specialised jurisdictions, such as the Maori Land Court in 1865 (originally called the Native Land Court), the Waitangi Tribunal in 1975, the Planning Tribunal in 1977 (renamed the Environment Court in 1996), the Family Court in 1981, and the Employment Court in 1991.

\section{The Genesis of the New Zealand Supreme Court}

The patriation of New Zealand's court of final appeal became official government policy in 1987 under the $4^{\text {th }}$ Labour government, spearheaded by the Minister of Justice, Geoffrey Palmer. The Law Commission considered alternatives to appeals to the Privy Council in its 1989 report The Structure of the Courts, ${ }^{7}$ recommending that a Supreme Court be established above the High Court, with the extinguishment of rights of appeal to the Privy Council. A change of government after the 1990 general election heralded a change in government policy, with the $4^{\text {th }}$ National government moving the idea of abolishing rights of appeal to

\footnotetext{
5 D. S. Beattie, et al., Report of Royal Commission on the Courts, AJHR, H.2. (Wellington, New Zealand: 1978).

${ }^{6}$ See Judicature Amendment Act 1980.

${ }^{7}$ New Zealand Law Commission, The Structure of the Courts, NZLC R7, AJHR E.31D (Wellington, New Zealand: 1989).
} 


\section{VICTORIAE REGIN正.}

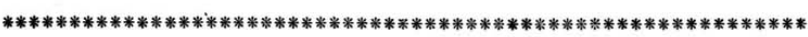

\section{Session II. No. I.}

AN ORdinance for establishing a Supreme Court.

SUPRBMr CovrT.

[2 2nd December, 1841.]

$\mathrm{B}^{\mathrm{E}}$ IT ENACTED by the Governor of New Zealand, with the advice Preamblo.

I.-CREATION OF COURT.

1. There shall be within the Colony of New Zealand a Court of Creation and stylo of record for the administration of justice throughout the Colony, which court. Court shall be called the Supreme Court of New Zealand.

$$
\text { II.-JURISDICTION OF COURT. }
$$

2. The Court shall have jurisdiction in all cases as fully as Her Legal Majesty's Courts of Queen's Bench Common Pleas and Exchequer at Westminster have in England, and shall be a Court of oyer and terminer and gaol delivery and assize and nisi prins.

3. The Court shall also have all such equitable jurisdiction as the Equitable Lord High Chancellor of Great Britain hath in England.

4. The Court shall also have exclusive jurisdiction in all questions Ecclesiastical. respecting the validity of wills of personal property.

5. The Court shall also have power to appoint and control guar- Lunacy. dians of infants and their estates, and also keepers of the persons and estates of idiots, lunatics, and such as being of unsound mind are unable to govern themselves and their estates.

6. The Court shall not take cognizance of any criminal case where Jursidiction the offence shall have been committed previous to the fourteenth day of January, one thousand eight hundred and forty.

7. There shall be made a Seal of the Court, and all writs and other seal. process issuing out of the Court shall be sealed therewith: Provided that until such Seal can be procured such writs and process shall be valid if signed by the Registrar.

$$
\text { III.-CONSTitution OF COURT. }
$$

8. The Court shall be holden before one Judge, who shall be Judges. called the Chief Justice of New Zealand, and such other Judges as Her Majesty or the Governor shall from time to time be pleased to appoint.

9. Every Judge before entering on his office shall take an oath in oath of office. the form in the Schedule hereunto annexed faithfully to execute the duties thereof.

10. There shall belong to the Court a Registrar and such inferior oficers of the Court. officers as to the Chief Justice shall appear necessary.

11. The

\section{Ill. 1 Supreme Court Ordinance 1841 (excerpt)}




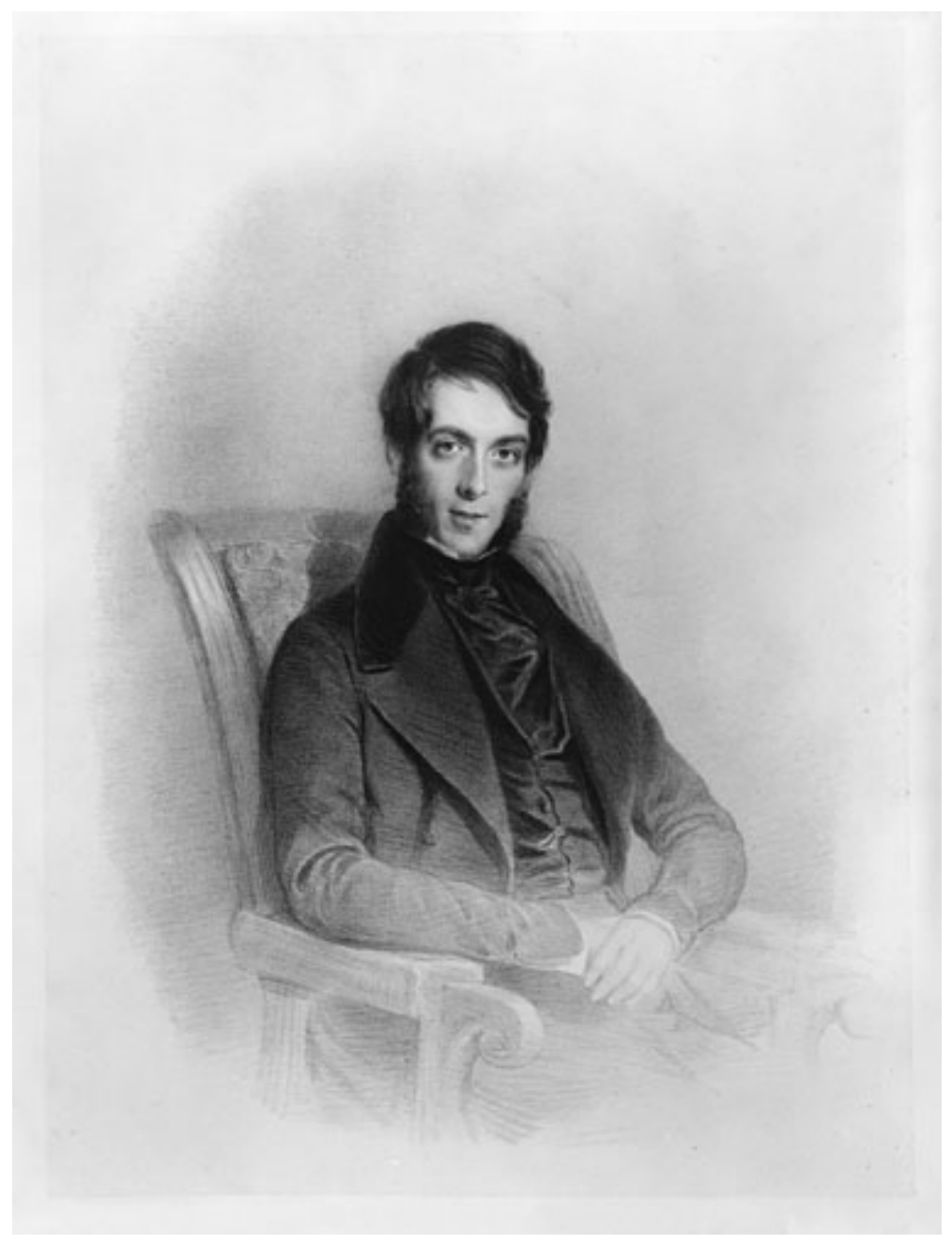

Ill. 2 Chief Justice William Martin, c. 1842

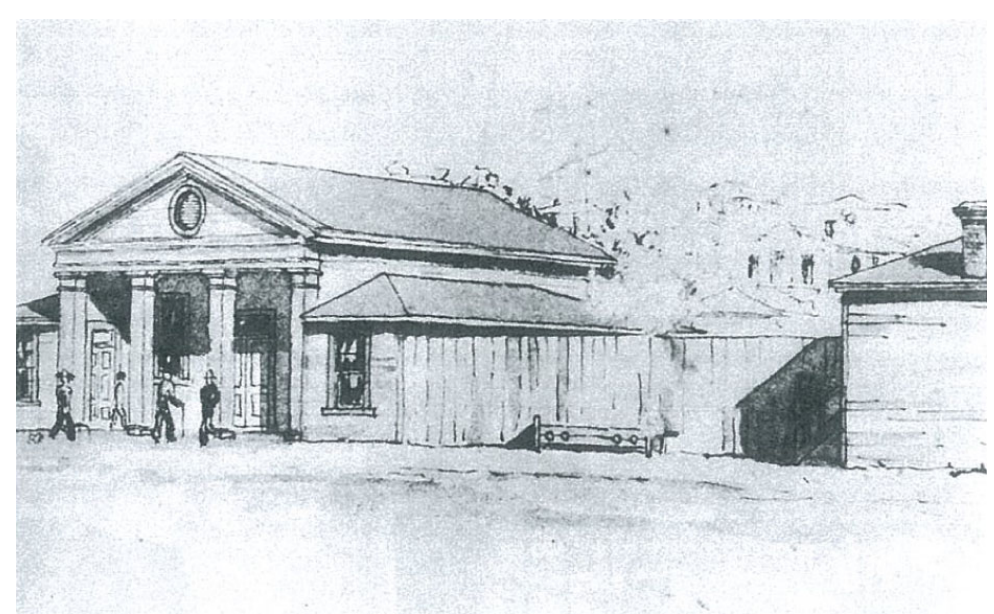

Ill. 3 First Auckland Supreme Court, c. 1841 
the Privy Council to the back burner, suggesting that such constitutional change might be possible, but only once New Zealand's appellate court structure were strengthened and then only if to do so would be fiscally neutral. A return to power in 1999 saw the $5^{\text {th }}$ Labour government revive discussion around the desirability of continued appeals to the Privy Council. The Solicitor-General, John McGrath, ${ }^{8}$ issued a report entitled Appeals to the Privy Council: Report of the Solicitor-General to the Cabinet Strategy Committee on Issues of Termination and Court Structure ${ }^{9}$ which recommended abolishing rights of appeal to Privy Council and replacing them with a single right of appeal from the High Court to the Court of Appeal. This report was followed in April 1996 by the introduction of the New Zealand Court Structure Bill, which included provisions abolishing appeals to the Privy Council.

\section{Reshaping New Zealand's Appellate Structure}

While the New Zealand Court Structure Bill did not proceed, by the late 1990s the push to patriate our court of final appeal had gained momentum. In December 2000 the AttorneyGeneral and Associate Minister of Justice, the Hon. Margaret Wilson, issued a discussion document on the matter, Reshaping New Zealand's Appeal Structure. ${ }^{10}$ The introduction to the report recognised New Zealand's long-standing reliance on the Privy Council, noting that, while historically appropriate while New Zealand had been a British colony governed directly from London, New Zealand had come a long way since and was by that point in time a

\footnotetext{
${ }^{8}$ Hon. Justice Sir John McGrath became a member of the Supreme Court bench on 4 May 2005.

${ }^{9}$ Office of the Solicitor-General, Appeals to the Privy Council: Report of the Solicitor-General to the Cabinet Strategy Committee on Issues of Termination and Court Structure (Wellington: Government Printer, 1995).

10 Office of the Attorney-General, Discussion Paper: Reshaping New Zealand's Appeal Structure (Wellington: Government Printer, 2000).
} 
"fully independent nation with a unique national identity."11 Ending appeals to the Privy Council seemed, in the Attorney-General's view, "inevitable" and necessary for creating an indigenous justice system which truly represented the nation's values and provided an inclusive and enduring appeal structure providing access to justice for all New Zealanders. ${ }^{12}$

The discussion paper suggested a number of reasons for ending rights of appeal to Privy Council: $:^{13}$

1. In terms of New Zealand's national identity and independence, ending appeals to the Privy Council would recognise New Zealand's constitutional status as an independent nation, reinforce New Zealand's confidence in its judiciary, and ensure final appeals were made by New Zealand-resident judges conversant with New Zealand society;

2. Many Commonwealth countries had already abolished links with the Privy Council (Ill. 4 \& 5$)^{14}$

3. Few New Zealand cases were heard by the Privy Council; ${ }^{15}$

4. New Zealand's changing international relationships meant that New Zealand's social and economic focus had shifted from Europe to Asia and the Pacific so ending

\footnotetext{
11 Attorney-General, Reshaping New Zealand's Appeal Structure, Introduction.

${ }^{12}$ Attorney-General, Reshaping New Zealand's Appeal Structure, Introduction. This view echoed that of Sir Robin Cooke (as he then was) in his address delivered at the 1987 New Zealand Law Conference, The New Zealand Legal Identity, published in (1987) 3 Canterbury Law Review 171, 182-3, quoted at ibid., para 2.

13 Attorney-General, Reshaping New Zealand's Appeal Structure, paras 5-14

${ }^{14}$ For example Canada (1933 and 1949), South Africa (1950), Australia (1975-1986), and Hong Kong (1997). Pakistan, Ireland, India, Malaysia, and Singapore had also already abolished appeals to the Privy Council, and Caribbean nations were at the time discussing replacing appeals to PC with a Regional Court of Appeal. Ibid., para 8.

15 Only 81 New Zealand cases were heard by the Privy Council between 1990 and 1999. Ibid., para 9.
} 
appeals would be unlikely to have a significant impact on business, nor isolate New Zealand from the international legal scene given New Zealand's active participation in international legal organisations; and

5. Although the Privy Council was essentially paid for by the United Kingdom taxpayer, the physical distance to London made taking appeals to the Privy Council prohibitively costly and therefore practicably inaccessible.

The paper also identified a number of arguments in support of retention, principally that the Privy Council remained a cost-effective way of providing an extra level of appeal in the NZ court hierarchy given that the costs associated were primarily borne by the United Kingdom and that the Privy Council provided better quality decisions and important detachment from local influences. ${ }^{16}$

A number of issues of specific concern to Māori were identified by Reshaping New Zealand's Appeal Structure, including the symbolic link to the Sovereign afforded by the Privy Council and the perception by some Māori that they received a more favourable hearing from the Privy Council than the Court of Appeal. ${ }^{17}$ However, the paper suggested that the number of appeals to the Privy Council concerning Māori interests was actually very limited, suggesting that the importance of the right of appeal to the Privy Council was of largely symbolic rather than practical value. ${ }^{18}$ That said, the discussion paper noted that any move to abolish rights

\footnotetext{
${ }^{16}$ Ibid., paras 15-18. The discussion paper noted that no qualitative evidence supported a view of better quality of decision making by the Privy Council and that detachment from the influences of local environment was seen by some to be detrimental as judges making decisions were largely unfamiliar with New Zealand society.

17 Ibid., paras 19-24.

18 The discussion paper noted that in the $20^{\text {th }}$ century there were approximately 13 appeals to the Privy Council which were of relevance to $\mathrm{M}$ ori. Most appeals affecting $\mathrm{M}$ ori rights and interests were dealt with by the New Zealand courts. Ibid., para 22.
} 
of appeal to the Privy Council would require the incorporation of recognition of Māori interests and values, suggesting that cognisance be taken of how Māori interests and values might be recognised and provided for within the New Zealand legal system (including greater representation of Māori within the justice system); how Māori values might be acknowledged within the substantive law; how processes might be incorporated to give the court of appeal access to expert advice on Māori values; and whether overseas judges might sit on the bench of the court of final appeal.

At this point in time, the Government's intention seems to have been that the Court of Appeal would fulfil the role of court of final appeal when rights of appeal to the Privy Council ended. The guiding principles ultimately suggested by the Attorney-General in considering the reshaping of the appeal structure were:

- Recognising the Court of Appeal as the New Zealand's final appellate court;

- Promoting reflective development of the law;

- Recognising $M$ ori values and the interests of $M$ ori under the Treaty of $W$ aitangi;

- Reflecting the nature of New Zealand society;

- Economic viability

- Meeting the needs of the community;

- Maintaining the independence of the judiciary;

- The effective use of resources;

- Simplicity;

- Efficient administration; and 
- Access to justice. $^{19}$

A number of these principles (indicated in emphasis above) bear direct importance to this study as expressions of judicial aspiration which resurface time and again in the development of the Supreme Court.

The discussion paper outlined three options for reshaping New Zealand's appeal structure based on a presumption of one level of appeal above the High Court, ${ }^{20}$ but public submissions on the report highlighted the desirability of maintaining two tiers of appeal above that level. ${ }^{21}$ Policy attention therefore moved to the possibility of a New Zealand Supreme Court.

Replacing the Privy Council: A New Supreme Court

In November 2001, Attorney-General Margaret Wilson established a Ministerial Advisory Group (MAG) on the potential purpose, structure, composition and role of a New Zealand court of final appeal. The MAG was chaired by the Solicitor-General, Terence Arnold QC, and included in its membership Christine Grice (President of the New Zealand Law Society), Shane Jones (chairperson of Te Ohu Kai Moana/Treaty of Waitangi Fisheries Commission), Dr Ngata Love (member of the Law Commission and Professor of $\mathrm{M}$ ori Business

\footnotetext{
${ }^{19}$ Ibid., para 25 and Appendix 1.

20 The three options were one level of appeal to the Court of Appeal; two levels of appeal within the Court of Appeal; or an appeal division within the High Court. Ibid., paras 27-41

${ }^{21}$ Office of the Attorney-General, Report of the Advisory Group. Replacing the Privy Council: A New Supreme Court. (Wellington: Government Printer, 2002), para 64.
} 


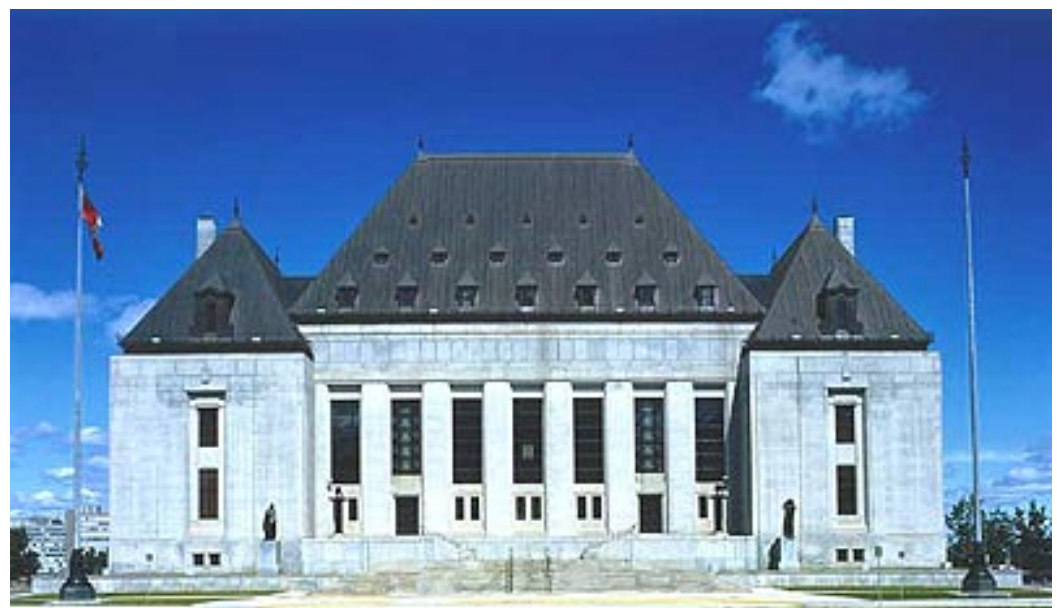

Ill. 4 Supreme Court of Canada, Ottawa.

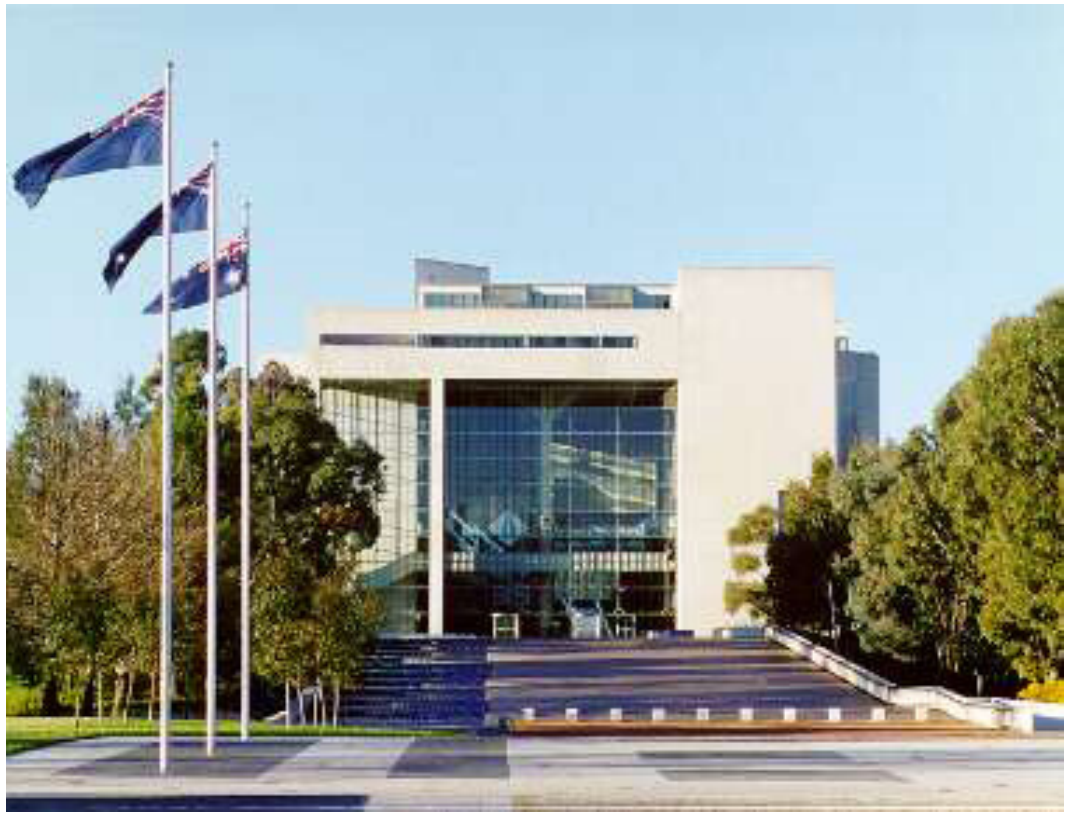

Ill. 5

High Court of Australia, Canberra. 
Victoria University of Wellington) and Hon Justice Bruce Robertson (President of the Law Commission). The President of the Court of Appeal, Rt. Hon Sir Ivor Richardson, acted as a special advisor to the Group. ${ }^{22}$ Given the earlier discussion document's identification of M ori as having specific issues to be addressed in any reform of the appellate structure, it is worth noting that five of the 14 standing members of the Group had backgrounds representing significant $\mathrm{M}$ ori interests, including the Waitangi Tribunal, Te Ohu Kai Moana/Treaty of Waitangi Fisheries Commission, and the M ori Congress. The MAG's terms of reference were seven-fold, the first two of which are directly relevant to the present discussion:

1. The purpose and role of the Final Appeal Court in New Zealand;

2. How the Court will reflect te ao M ori in its establishment, structure and processes;

3. The jurisdiction of the Court;

4. The composition and number of judges appointed to the Court, including whether judges from different jurisdictions should be appointed;

5. The role and responsibilities of the Head of the Final Appeal Court;

6. Where the Court should be located; and

7. Any other matter that was relevant to advise on the model for the Final Appeal Court. $^{23}$

The Group was not asked to comment on the desirability or otherwise of abolishing appeals to the Privy Council, only how an appellate court above the Court of Appeal might be

\footnotetext{
22 Ibid., Appendix A.

${ }^{23}$ Ibid., Appendix B.
} 
structured. ${ }^{24}$ The MAG reported back to the Attorney-General in April 2002. The AttorneyGeneral's Foreword to the published report noted the Group's conclusion that replacing the Privy Council with a Supreme Court should improve accessibility to New Zealand's highest court (physically and jurisdictionally) and improve the understanding of local conditions by judges on that court. ${ }^{25}$ Replacing the Privy Council: A New Supreme Court made a number of detailed recommendations for a New Zealand Supreme Court, including the following:

1. The highest court in New Zealand's justice system should be called the Supreme Court of New Zealand. ${ }^{26}$

2. A New Zealand-based Supreme Court would be an important, visible and relatively accessible institution $^{27}$ and should better reflect the diversity of New Zealand society than the Privy Council, with the composition of the Court being such as to ensure a wide range of skills and experience, including a sound knowledge of tikanga $\mathrm{M}$ ori. ${ }^{28}$

3. The Supreme Court should perform a traditional appellate court role - error correction and clarification and development of the law. ${ }^{29}$ The statutory criteria for leave to appeal to the Supreme Court should allow an appeal on a matter that raises a significant issue concerning the Treaty of Waitangi or tikanga $\mathrm{M}$ ori. ${ }^{30}$

\footnotetext{
${ }^{24}$ Ibid., para 1.1.

${ }^{25}$ Ibid., 'Foreword' and para 1.2.

${ }^{26}$ Ibid., para 1.3.

27 Ibid., para 39.

${ }^{28}$ Ibid., para 58.

${ }^{29}$ Ibid., para 41.

${ }^{30}$ Ibid., paras 62 and 152.
} 
4. In terms of physical accommodation, the Supreme Court should be located in Wellington, which would reflect the symbolic importance of the Court by situating it in the capital city and close to the centre of government. ${ }^{31}$ There is a preference for the Court to be located in the former High Court premises in Ballance Street, although the principal consideration should be providing a suitable work environment. $^{32}$

5. Consideration could be given to a different layout for the Supreme Court, for example, along the lines of the current layout of the Privy Council, which is semicircular and with judges and counsel at the same level. The layout should reflect that it is a New Zealand Court. ${ }^{33}$

Like the Attorney-General's guiding principles for judicial system reform in Reshaping New Zealand's Appeal Structure, the MAG's recommendations are significant expressions of judicial aspiration of the Supreme Court.

The Supreme Court Act 2003

Constitutional change, usually a glacial process, came relatively quickly after the release of the MAG's report. The Group's recommendations were considered by Cabinet and directly informed the Supreme Court Bill, which was introduced to Parliament on 9 December

\footnotetext{
${ }^{31}$ Ibid., para 166.

32 Ibid., para 167.

33 Ibid., para 168.
} 
2002. ${ }^{34}$ The Supreme Court Bill adopted as its overarching objective the improvement of access to justice through:

- Improving the accessibility of New Zealand's highest court; and

- Broadening the range, and increasing the volume, of appeals considered by New Zealand's highest court; and

- Using the greater understanding of local conditions of the judges of New Zealand's highest court. ${ }^{35}$

These aspirations found direct expression in the legislative purpose of the Supreme Court, found in section 3 of the SCA:

3 Purpose

(1) The purpose of this Act is-

(a) to establish within New Zealand a new court of final appeal comprising New Zealand judges-

(i) to recognise that New Zealand is an independent nation with its own history and traditions; and

(ii) to enable important legal matters, including legal matters relating to the Treaty of Waitangi, to be resolved with an understanding of New Zealand conditions, history, and traditions; and

(iii) to improve access to justice; and

(b) to provide for the court's jurisdiction and related matters; and

(c) to end appeals to the Judicial Committee of the Privy Council from decisions of New Zealand courts; and

(d) to make related amendments to certain enactments relating to courts or judicial proceedings.

\footnotetext{
${ }^{34}$ Supreme Court Bill 2002 (16-1), Explanatory Note, p 2; Supreme Court Bill 2002 (16-2), Commentary, p 3.

${ }^{35}$ Supreme Court Bill 2002 (16-1), Explanatory Note, p 1.
} 
(2) Nothing in this Act affects New Zealand's continuing commitment to the rule of law and the sovereignty of Parliament.

As it is suggested that section 3 is a key expression of the judicial aspirations of the Supreme Court, an in-depth understanding section 3 is of fundamental importance to the present study and so will form part of Chapter IV, Briefing the Supreme Court Project.

The New Zealand Supreme Court sat (ceremonially) for first time on 1 July 2004, in temporary accommodation within the Wellington High Court premises. ${ }^{36}$ In his commemoratory speech, Chris Dalow, President of the New Zealand Law Society, expressed the key roles of the Court in valuing and safeguarding the rule of law, recognising judicially the cultural values of $\mathrm{M}$ ori and other ethnic minorities, preserving the concept of open justice, and in ensuring that every citizen has an educated understanding of the role of the judiciary, the relationships between the courts and other organs of government, and an understanding of the courts and other processes. ${ }^{37}$ The Chief Justice's speech was perhaps illustrative of the mood of the judiciary on the dawn of what the Attorney-General called “our legal 'coming of age" ". ${ }^{38}$ As head and representative of the judiciary, Her Honour noted that the institution of the Supreme Court was "greater than the sum of its parts" and

\footnotetext{
36 The Supreme Court continued to sit in the temporary premises in the Wellington High Court building until the opening of the new Supreme Court building on 18 January 2010.

${ }^{37}$ Chris Dalow, "New Zealand Law Society President's Address on the Ceremonial Sitting of the Supreme Court” (1 July 2004). http://www.courtsofnz.govt.nz/from/speeches-and-papers/\#speechpaper-list-firstsitting

38 Margaret Wilson, “Address of the Attorney-General of the First Sitting of the Supreme Court” (1 July 2004). http://www.courtsofnz.govt.nz/from/speeches-and-papers/\#speechpaper-list-first-sitting
} 
that the judges' role was to serve an idea "much bigger than all of us." 39 The Chief Justice went on to say:

What we should celebrate is the aspiration for the delivery of justice which has prompted the creation of the Court. Those aspirations have been with us from the very beginning. In February 1840 at Waitangi much of the debate was about law and its administration. I doubt whether any country was founded with such expectations of law as ours. The creation of a final court of appeal in New Zealand furthers those aspirations for justice. ${ }^{40}$

\section{The Constitutional Role of the Supreme Court}

In order to fully understand the constitutional role of the Supreme Court, one must understand the nature of New Zealand's constitutional arrangements. As Palmer points out, "[a] nation's constitution is the set of rules that governs the exercise of public power. It determines who exercises power and how they do it." ${ }^{41}$ Palmer contends that "[p]ublic power is still the most awesome human force in the nation state of New Zealand," ${ }^{42}$ a force that strongly influences the shape of New Zealand society:

$[\mathrm{T}]$ he views of a government can still exert a powerful pull, or push, on the values and beliefs of New Zealanders - on our social identities, relationships and cultures. Our constitution, in governing the behaviour of the branches of New Zealand government that exercise public power, significantly affects the economy, polity, society and culture that constitutes New Zealand collectively. ${ }^{43}$

\footnotetext{
${ }^{39}$ Sian Elias, "Speech at the Special Sitting of the New Zealand Supreme Court" (1 July 2004). http://www.courtsofnz.govt.nz/from/speeches-and-papers/\#speechpaper-list-first-sitting

${ }^{40}$ Elias, "Supreme Court Special Sitting Speech."

${ }^{41}$ Matthew S. R. Palmer, The Treaty of Waitangi in New Zealand's Law and Constitution. (Wellington: Victoria University Press, 2008), 234.

42 Ibid., 234.

43 Ibid.
} 
New Zealand's constitution is found not in one all-encompassing document but rather in a variety of sources, some codified, others not, including the Constitution, Electoral and Judicature Acts; ${ }^{44}$ the prerogative powers of the Queen; ${ }^{45}$ decisions of the courts (especially those of the Supreme Court on constitutional matters); and constitutional conventions such as the rule of law and the doctrine of Parliamentary sovereignty. The Treaty of Waitangi is also recognised as being of constitutional significance as "a basic constitutional document," being of the "highest constitutional significance," and a "founding document of government in New Zealand.",48

Under the doctrine of the separation of powers, the judiciary is one of the three branches of constitutional government, working alongside but independently of the legislature and the executive. As New Zealand's court of final appeal, the Supreme Court sits at the apex of the judiciary with the Chief Justice as its head (Ill. O). The constitutional function of the New Zealand judicial system is to administer justice by interpreting and applying the law, including enforcing the criminal law, resolving civil disputes amongst citizens, upholding the rights of the individual, and ensuring that government agencies stay within the law; the disputes resolved by the judiciary affect virtually every aspect of New Zealand life. The Supreme

\footnotetext{
${ }^{44}$ See Judicature Act 1908, Constitution Act 1986, and Electoral Act 1993.

45 See 'Governor-General' in Cabinet Office, Cabinet Manual 2008 (Wellington: Government Printer, 2008) http://www.cabinetmanual.cabinetoffice.govt.nz/node/22\#1.8

46 Waitangi Tribunal, Ngai Tabu Report (Wai 27) (Wellington: Government Printer, 1991) 4.4.4, cited in Palmer, The Treaty of Waitangi, 234.

47 New Zealand M ori Council v Attorney-General [1994] 1 NZLR 513, 516 (per Lord Woolf), cited in Palmer, The Treaty of Waitangi, 234.

48 Sir Kenneth Keith, 'On the Constitution of New Zealand: An Introduction to the Foundations of the Current Form of Government', in Cabinet Office, Cabinet Manual 2008 (Wellington: Government Printer, 2008) http://www.cabinetmanual.cabinetoffice.govt.nz/
} 
Court is not concerned with the day-to-day administration of justice per se, but rather is reserved for correcting errors in the judgments of inferior courts and in the clarification and development of the law. Thus it maintains a supervisory watch over the judicial system as a whole. For this reason, leave to appeal to the Supreme Court may only be granted where the appeal raises issues that involve matters of general or public importance, general commercial significance, or the occurrence (or possible occurrence) of substantial miscarriages of justice. ${ }^{49}$ Significantly, the Act specifically recognises a significant issue relating to the Treaty of Waitangi as a matter of general or public importance per $s e^{50}$

Looking back at the purposes of the Supreme Court as stated in section 3 of the SCA, ${ }^{51}$ there are two aspects of New Zealand's constitution that must be explained in order to fully comprehend the role of the Supreme Court within it: the doctrines of the rule of law and

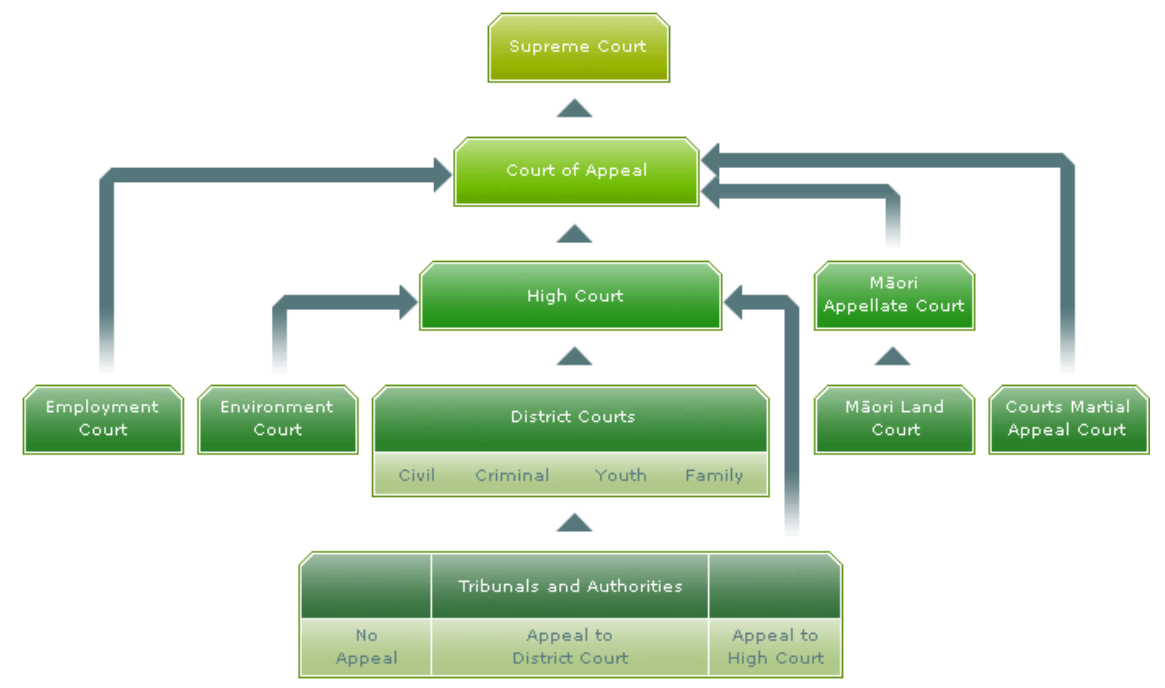

Ill. 6 The New Zealand Court Hierarchy since 1 July 2004

\footnotetext{
49 Supreme Court Act 2003, s 13(2).

50 Supreme Court Act 2003, s 13(3).

51 See p 37.
} 
Parliamentary sovereignty, and the constitutional status of the Treaty of Waitangi.

Understanding these two fundamental matters is essential to understanding the reasons

Parliament saw fit to expressly incorporate them into the purpose section of the Supreme

Court's enabling legislation.

\section{The Rule of Law}

An essential function of the judicial system (and of the Supreme Court in particular) is that it is responsible for upholding a fundamental tenet of our constitution, the rule of law. A narrow definition of the rule of law requires that a state (acting through government officials) and its citizens are bound by and must act consistently with the law. ${ }^{52}$ Tamanaha identifies two functions of the rule of law: 1) to impose legal restraints on government officials; and 2) to maintain order and co-ordinate behaviour and transactions between citizens. ${ }^{53}$ Inherently problematic in part 1 of this formulation of the rule of law is that the state makes the very laws to which it is required to adhere. Indeed in New Zealand the state (through Parliament, its body of elected representatives) is the sole and supreme law maker. ${ }^{54}$ This situation is ameliorated through the separation of powers - the institutionalised distance between law maker (the legislature), law enforcer (the executive) and arbitrator of the law (the judiciary). It is crucial to the operation of the rule of law that there be an institutionalised body with ultimate say over the interpretation and application of the law independent from the bodies

\footnotetext{
52 Brian Z. Tamanaha, A Concise Guide to the Rule of Law. St. John's University School of Law Legal Studies Paper \#07-0082. (New York: St John's University, 2007) 3. http://ssrn.com/abstract=1012051

${ }^{53}$ Ibid.

${ }^{54}$ The sovereignty of Parliament is expressed in s 15 of the Constitution Act 1986 and recognised in s 3(2) of the Supreme Court Act 2003. The inclusion of this provision was recommended by the Justice and Electoral Select Committee in its report on the Supreme Court Bill in order to reinforce that the Supreme Court would have no ability to review the legislature's power to enact laws such as that the US Supreme Court holds.
} 
making and enforcing the same. In New Zealand this body is the judicial system, from the most specialised of tribunals to the Supreme Court.

Judicial independence is a cornerstone of the separation of powers. Under the Constitution Act 1986 judges are independent from the legislature and executive, holding office at the will of the sovereign (as opposed to that of the executive) with security of tenure and remuneration. ${ }^{55}$ Judges are appointed by the sovereign on the recommendation of the Attorney-General (acting independently of political considerations) and can only be removed from office through function of age or by the Sovereign following an address from Parliament (on grounds of incapacity or misconduct). Constitutional conventions prevent the executive interfering with the judiciary, either directly or indirectly by, for example, adverse comment on case outcomes; judges can only be directed by Parliament through duly enacted legislation. Immunity from being sued in their private capacity in respect of actions taken against them in their professional role protects judges from civilian interference.

A principal benefit of the rule of law is that it creates a level of certainty, predictability and security in interactions between citizens and the state and citizens inter se, enabling people to know in advance the extents of actions they may freely undertake without fear of legal sanction or restriction, restricting arbitrary or wilful actions by government officials, facilitating economic development, and enabling a sense of justice in that the law is seen to be applicable to everyone equally. However, the rule of law does not exist per se. Tamanaha explains that for the rule of law to exist the state and its citizens must share an orientation that believes in and is committed to the rule of law, taking it for granted as a necessary,

\footnotetext{
55 See s 23 and s 24 Constitution Act 1986.
} 
proper and existing part of their political-legal system. Further, it requires the presence of an institutionalised and independent judiciary and existence of a robust legal profession and legal tradition committed to upholding the rule of law. ${ }^{56}$ This is significant in appreciating the crucial role of the Supreme Court in upholding the rule of law: it sits at the apex of the judicial branch of the separation of powers; it provides physical access to the machinery of justice; it hears cases in open court and delivers publicly available judgments providing transparency in the administration of the law; and its courthouse provides a physical, concrete representation of notions of "Justice" to the other branches of government and the community at large.

\section{The Treaty of Waitangi}

As noted above, the Treaty of Waitangi is now considered by many to be New Zealand's founding document and a living text within New Zealand's constitutional framework. ${ }^{57}$ This is significant because, as discussed in Chapter I, one the judicial aspirations of the Supreme Court is to resolve New Zealand legal disputes with an understanding of their context, including the Treaty of Waitangi. It is suggested that, as the Treaty is one facet of the constitutional lens through which all Crown exercise of public power must be viewed, an understanding of the status and force of the Treaty in the New Zealand legal system is essential in order to fully understand this aspect of the Supreme Court's purpose.

\footnotetext{
56 Tamanaha, The Rule of Law, 13-15.

${ }^{57}$ See, for example, Sir Robin Cooke, 'Introduction' (1990) 14 New Zealand Universities Law Review 1, where Cooke describes the Treaty as being "simply the most important document in New Zealand's history."
} 
The British Crown assumed sovereignty over New Zealand through the signing of the Treaty of Waitangi. ${ }^{58}$ At first the Treaty did not make much difference to the status quo, however with the steady influx of settlers the Crown asserted its sovereignty more and more and it became clear that Treaty rights and protections would be relied upon by $\mathrm{M}$ ori to protect their interests. One rule of international law (then and now) which probably escaped the $\mathrm{M}$ ori signatories is that a treaty has no legal effect within a domestic jurisdiction unless and until it is incorporated into domestic law; thus the Treaty did not have the force of law in the new New Zealand legal system. While M ori may not have understood the limited justiciability of the Treaty of Waitangi due to its legal status, they nevertheless sought the assistance of the early New Zealand courts to resolve alleged breaches of the Crown's Treaty promises. The Treaty first came before the New Zealand Courts in 1847 where the first Chief Justice of the colony Justice Chapman noted that the Treaty "does not assert either in doctrine or precedent anything new and unsettled," ${ }^{59}$ that is to say, the rights of $\mathrm{M}$ ori in relation to their lands were not affected by the Treaty, the Treaty simply explicated the common law status quo. This view did not persist however. Recognition of the extant nature of $\mathrm{M}$ ori rights and the protection of the same by the Treaty was subsequently eroded by the courts until Chief Justice James Prendergast infamously declared in his Wi Parata v Bishop of Wellington (1877) judgment that the Treaty, "so far as it purported to cede the sovereignty of New Zealand, it was a simple nullity for no body politic existed capable of making cession

\footnotetext{
${ }^{58}$ The background to the signing of the Treaty and the semantic differences between the English and M ori texts of the Treaty are constitutionally significant, but not of present concern. Three seminal texts may assist readers unfamiliar with the history of the Treaty of Waitangi: Claudia Orange's The Treaty of Waitangi $2^{\text {nd }}$ ed. (Wellington: Bridget Williams Books, 2011); Michael King's The Penguin History of New Zealand (Wellington: Penguin, 2003); and Palmer's The Treaty of Waitangi.

${ }^{59} \mathrm{R} v$ Symonds (1847) NZPCC 388, 390.
} 
of sovereignty." ${ }^{60}$ Prendergast CJ's views on the legal status of the Treaty permeated the New Zealand legal system for the next century, during which time a number of significant decisions of the courts eroded or outright rejected the legal status and force of the Treaty. ${ }^{61}$

For M ori, however, decades of denial (or avoidance) of the Treaty's force at law by judges and the Crown did not stop repeated attempts to gain redress from the Crown via the courts. Access to the courts (including the Privy Council) remained important as a means of obtaining audience with and relief from the Crown with whom they had signed the Treaty. ${ }^{62}$ In the 1970s a political shift in New Zealand became evident with protests by $\mathrm{M}$ ori and P keh alike demanding that the Treaty be honoured, an attitudinal shift to which legislators responded. ${ }^{63}$ In 1975 the 3rd Labour government established the Waitangi Tribunal. A significant step was taken when, in 1986, Parliament enacted the State-Owned Enterprises Act 1986, which for the first time in New Zealand legislation referred to the "principles" of the Treaty of Waitangi, requiring those acting under the Act to perform their duties in accordance with those principles. ${ }^{64}$ Similar provisions were incorporated into subsequent legislation, for example, the Conservation Act 1987, the Education Act 1989, the

${ }^{60}$ Wi Parata v The Bishop of Wellington (1877) 3 NZ Jur (NS) SC 72.

${ }^{61}$ See, for example, Nireaha Tamaki v Baker (1901) NZPCC 371; (1902) AC 561; Hohepa Wi Neera v Bishop of Wellington (1902) 21 NZLR 655 (CA); Baldick v Jackson (1911) 13 GLR 398; Tamihana Korokai v Solicitor-General (1912) 32 NZLR 321; W aipapakura v Hempton (1914) 33 NZLR 1065; Hoani Te Heubeu Tukino v Aotea District Maori Land Court (1941) AC 308; Re the Bed of the Wanganui River [1963] NZLR 673; and In re the Ninety Mile Beach [1955] NZLR 419.

${ }^{62}$ The notion of "the Crown" is complex. At first the Crown meant "the British Crown" i.e. Queen Victoria and her Ministers; as New Zealand gained responsible government it came to mean "the Crown in respect of New Zealand" i.e. the Monarch and his or her New Zealand executive. See Janine A. D. Hayward, "In Search of a Treaty Partner: Who, or What, is the Crown?” (PhD diss., Victoria University of Wellington, 1995). http://hdl.handle.net/10063/744

${ }^{63}$ Dame Whina Cooper's 1975 hikoi (land march) and the 1978 Bastion Point occupation are but two largescale examples of this shift.

${ }^{64}$ State-Owned Enterprises Act 1986, s 9. 
Crown Minerals Act 1991 and the Public Records Act 2005. After a century of dismissal, these provisions opened the floodgates for fresh consideration of the Treaty by the New Zealand courts, albeit consideration based on the essence of the Treaty rather than its strict legal status. The first case to consider the principles of the Treaty was New Zealand M ori Councilv Attorney-General" (the "Lands Case"), a case which turned on the interpretation of section 9 of the State-Owned Enterprises Act 1986. The Court of Appeal's judgments ${ }^{66}$ in this case identified a number of Treaty principles based on the "spirit" rather than the strict text of the Treaty. Significant for the present discussion were the principles of partnership and active protection; the Court found that the Treaty established a partnership which imposed on the partners a duty to act reasonably and in good faith, ${ }^{67}$ and which required the Crown to actively protect those interests of $\mathrm{M}$ ori guaranteed by the Treaty. ${ }^{68}$ Although they have each articulated the principles of the Treaty in their own ways, the Crown, Parliament and the Waitangi Tribunal have all consistently endorsed these two principles. ${ }^{69}$

What though is the force of the Treaty in the $21^{\text {st }}$ century? Palmer suggests that it remains fundamental to our constitution and:

\footnotetext{
${ }^{65}[1987] 1$ NZLR 641.
}

${ }^{66}$ Such was the significance of the Lands case that, while the Court of Appeal reached a unanimous decision, each of the five judges who heard the case - Cooke P, Richardson J, Somers J, Casey J, and Bisson J - issued separate judgments with the reasons for their decision.

${ }^{67}[1987] 1$ NZLR 641, 667 (per Cooke P)

${ }^{68}$ [1987] 1 NZLR 641, 664 (per Cooke P)

${ }^{69}$ See, for example, Te Puni Kokiri and Ministry of Justice, Te Whanaungatanga a te Karauna me te $M$ ori: $\mathrm{Ng}$ tohutobu mo te kawanatanga me ng tari kawanatanga/Crown-M ori Relationship Instruments: Guidelines and Advice for Government and State Sector Agencies (Wellington: Government Printer, 2006), Appendix 3 (Cabinet Approved Treaty Statements); Te Ture Whenua M ori Act 1993 (Preamble) and Ng ti T rangitukua Claims Settlement Act 2006 (s 5); and Waitangi Tribunal, Report of the Waitangi Tribunal on the Orakei Claim (Wai 9) (Wellington: Government Printer, 1987) 11.10.1 (partnership) and Waitangi Tribunal, Report of the Waitangi Tribunal on the Manukau Claim (Wai 8) (2 $2^{\text {nd }}$ ed., Wellington: Government Printer, 1989) 8.3 (active protection). 
$[\ldots .$.$] is best understood as representing an explicit commitment to the health of the relationships$ between the Crown, M ori and other New Zealanders. This is the common re-interpretation of the general meaning of the Treaty that has emerged from constitutional dialogue between the Waitangi Tribunal, the Court of Appeal, Parliament and the executive branch of government since the early 1970 s. ${ }^{70}$

Palmer's view reinforces a long-held view of many $\mathrm{M}$ ori that, through the Treaty, there exists a direct relationship with the Crown, a relationship accessible through the courts. For many $\mathrm{M}$ ori, the ability to take cases to the Privy Council was a key aspect of this accessibility. Although very few appeals of significance to $\mathrm{M}$ ori interests were heard by the Privy Council between 1840 and the end of the $20^{\text {th }}$ century, the Privy Council represented to many M ori a direct link to the Monarch, removed from the influence of daily New Zealand life. It was understandable, therefore, that many groups representing $M$ ori interests were concerned when the Government announced its intention to remove rights of appeal to the Privy Council. This situation was clearly in the Government's mind when creating the Supreme Court; as noted in the preceding subsection, the fundamental role of the Treaty in New Zealand's legal system was expressly referenced in the Supreme Court's enabling legislation.

This section indicates that a purely legalistic analysis of the Treaty gives an incomplete understanding of the status and force of the Treaty in New Zealand's constitutional framework. As Palmer suggests, the key on-going constitutional issue surrounding the Treaty is the $\mathrm{M}$ ori-Crown relationship established by the Treaty and recognised and affirmed by the Waitangi Tribunal, the courts, Parliament and the Crown. The inclusion of

\footnotetext{
${ }^{70}$ Palmer, The Treaty of Waitangi, 24.
} 
references to the Treaty in the purpose and leave to appeal criteria sections of the Supreme Court Act are express reminders of the role the Supreme Court as the apex of the judicial branch of government must play in upholding the Treaty's constitutional position. ${ }^{71}$ This is significant. On replacing the Privy Council, the Supreme Court stepped into its shoes judicially and symbolically; $\mathrm{M}$ ori will continue to look to the courts to clarify and reinforce the Treaty principles and the importance of Supreme Court as judicial arbiter of the special relationship between $\mathrm{M}$ ori and the Crown should not be underestimated.

\section{New Zealand Judicial Architecture}

Unfortunately, the architectural history of New Zealand's courthouses is relatively poorly understood at present. Many early New Zealand courthouses are all but lost to the public record (particularly in the main commercial centres, for example the original Auckland (1841), Wellington (1865) (Ill. 7) and Dunedin (c. 1850) (Ill. 8) Supreme Courts), having been replaced and demolished within a decade or two of their openings. Together with the wealth of published information on the early work of government architects, ${ }^{72}$ the entry of many historic courthouses onto the New Zealand Historic Places Trust (NZHPT) Register means a great deal of information is available on early courthouses, many of which remain in operation today. However, such focused attention has not been given to later examples of the typology. This section gives a brief overview of New Zealand's judicial architecture from

\footnotetext{
${ }^{71}$ See pp. 44 and $82 f$.

72 See for example Peter Richardson, "Building the Dominion: Government Architecture in New Zealand, 1840 - 1922” (Ph.D. diss., University of Canterbury, 1997); Lewis E. Martin, Built for Us. The Work of Government and Colonial Architects, 1860s to 1960s (Dunedin: University of Otago Press, 2004); John Stacpoole, Colonial Architecture in New Zealand (Wellington: Reed, 1976); and Rosslyn J. Noonan, By Design: A Brief History of the Public Works Department, Ministry of Works 1870 - 1970 (Wellington: Government Printer, 1975).
} 
1840 to 2010 based on information currently available, but illustrates that large gaps in knowledge exist and further investigation is warranted.

The stories of the development of the New Zealand justice system and that of New Zealand architecture are very similar. They are both tales of building on what has been handed down from a colonial parent in order to find an indigenous way of doing things. Like the judicial system, the New Zealand courthouse typology has its origin in the English legal system. The first New Zealand courthouses were established in areas of high concentration of European settlers, particularly in early commercial centres such as Auckland, but also on the Coromandel Peninsula and in Central Otago areas where the discovery of gold had led to an influx of settler prospectors keen to make their fortunes in the new colony. ${ }^{73}$ Indeed the establishment of courthouses maps the early economic development of the nation - where prosperity arose, so did the need for law and order.

New Zealand's early courthouses were small, often jointly serving as offices for the administrators of the goldfields, regional police barracks and gaols, and post offices, for example the former Queenstown courthouse (1880)(Ill. 9). This multi-purpose functionality was borne of necessity in the new colony, but also had its precedents in the combined town hall/law court complexes of England and continental Europe found from the Middle Ages to the $19^{\text {th }}$ century. ${ }^{74}$

\footnotetext{
${ }^{73}$ For example, the first courthouse in Clyde was a calico and scantling building constructed in 1862, the year Clyde was legally proclaimed a goldfield. See NZHTP "Clyde Courthouse (Former)" http://www.historic.org.nz/TheRegister/RegisterSearch/RegisterResults.aspx?RID=2379

${ }^{74}$ For example the Amsterdam Town Hall (since 1808, Royal Palace of the Netherlands) and the English Royal Courts of Justice which originally sat in Westminster Hall, part of Westminster Palace. A dedicated Royal Courts of Justice building opened in London in 1882. See Judith Resnik \& Dennis E. Curtis "Representing Justice: From Renaissance Iconography to Twenty-First-Century Courthouses" Proceedings of the American
} 


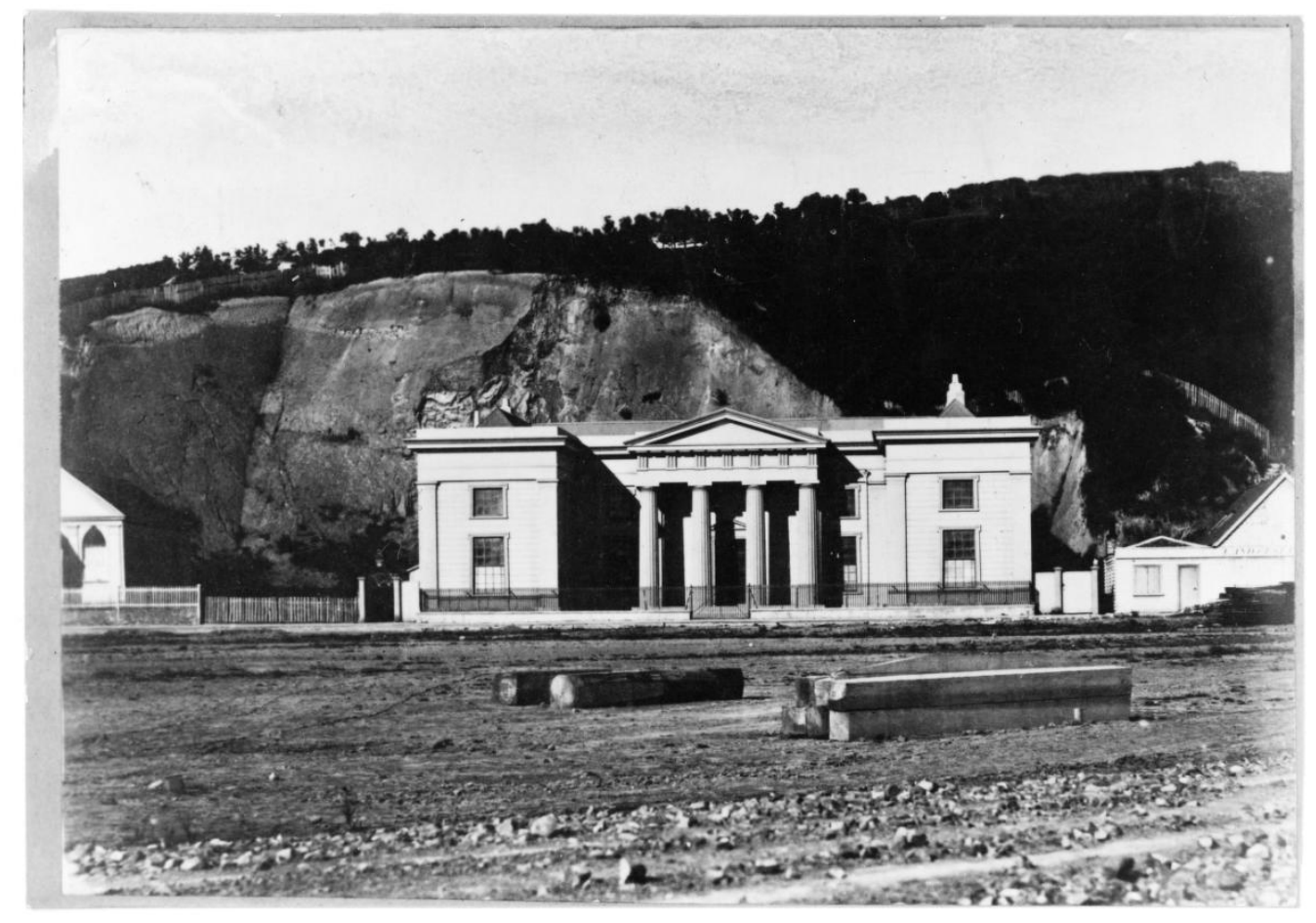

Ill. 7 Former Wellington Supreme Court, c. 1865

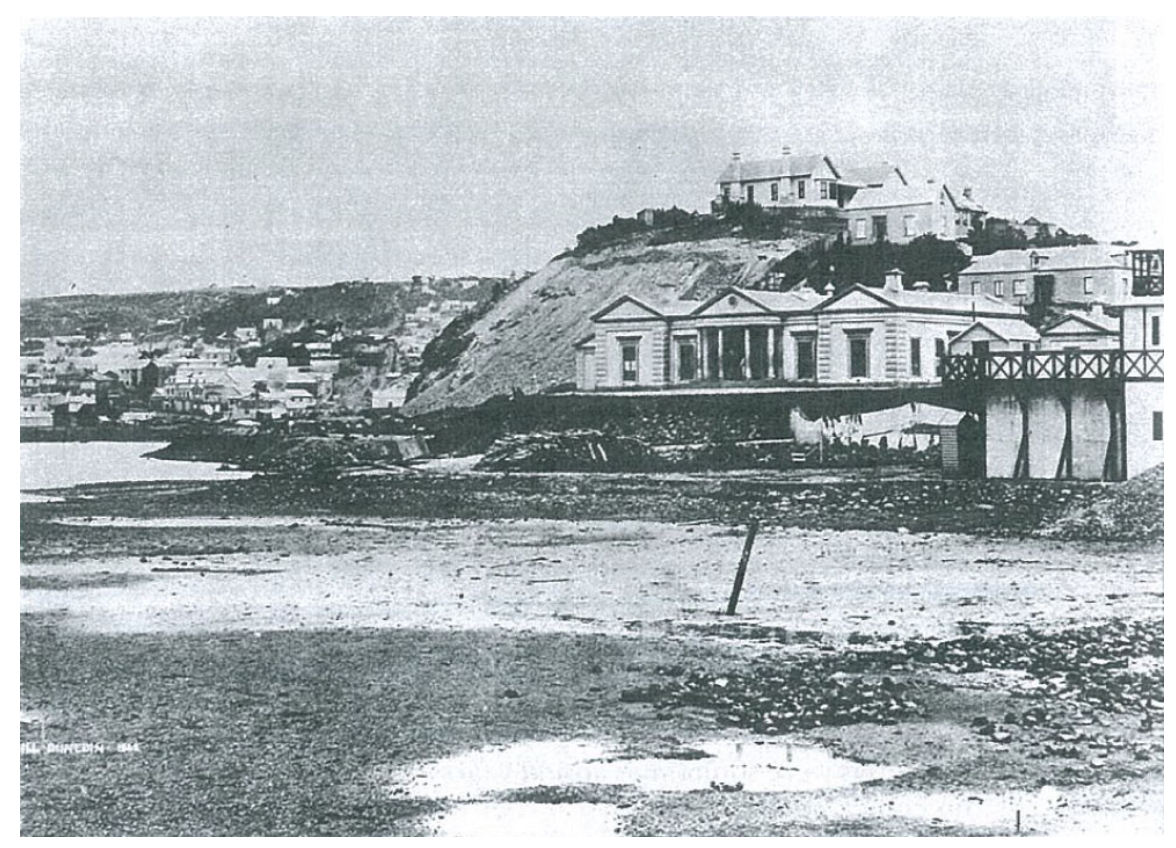

Ill. 8 Former Dunedin Supreme Court, c. 1850

Philosophical Society (2007) 151(2): 139-183, 155 and Nikolaus Pevsner, A History of Building Types (London: Thames and Hudson, 1976) 53. 
The early New Zealand courts were of varied construction, predominantly making use of readily available local materials such as kauri in the Coromandel and stone in Central Otago. The designs of the early courthouses were relatively consistent however, a consistency most easily explained by the near monopoly of the colonial and government architects on the design of courthouses. Henry William Clayton (1823 - 1877) (Ill. 10), appointed New Zealand's first Colonial Architect in 1869, was a prolific designer of early courthouses, including the former Reefton (1872), Coromandel (1873)(Ill. 11), Naseby (1875), Napier (1875), Rawene (1876) and Akaroa (1878)(Ill. 12) courthouses. ${ }^{75}$ Martin notes that Clayton found little precedent for buildings so small and yet so prestigious, and that, while they were mostly constructed in local timber, they were designed to be more formal than other "standard plan" buildings he designed, emphasising the "iconic power of simple shapes.,"76

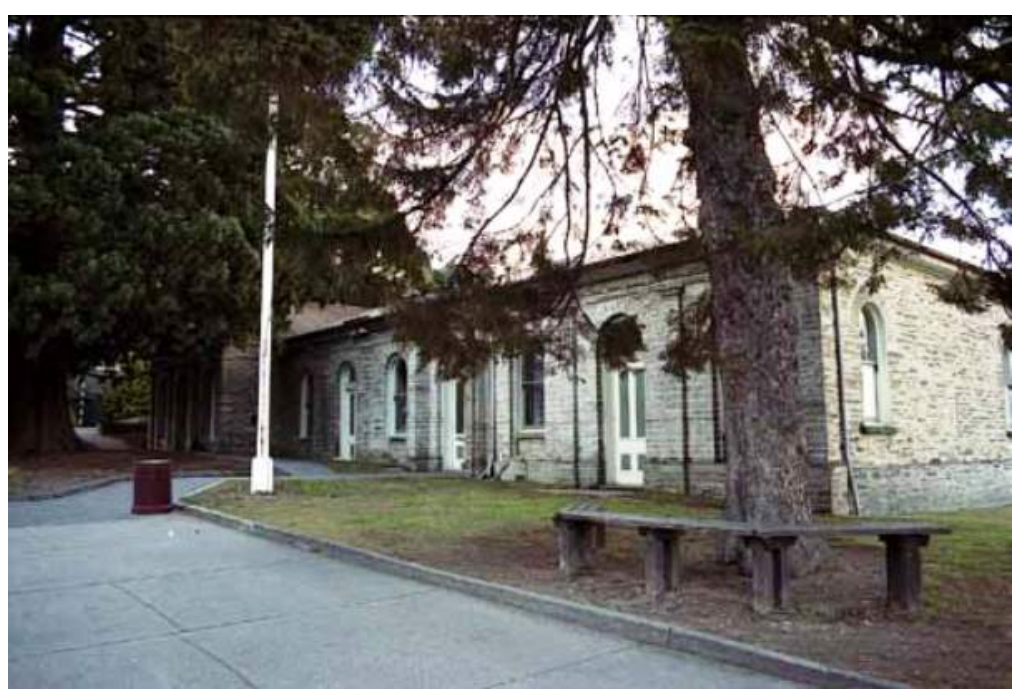

I11. 9 Former Queenstown Courthouse and Library

\footnotetext{
${ }^{75}$ Stacpoole reports Clayton was the author of at least 16 courthouses during his tenure as Colonial Architect. See Stacpoole, Colonial Architecture, 131.

${ }^{76}$ Martin, Built for Us, 16.
} 


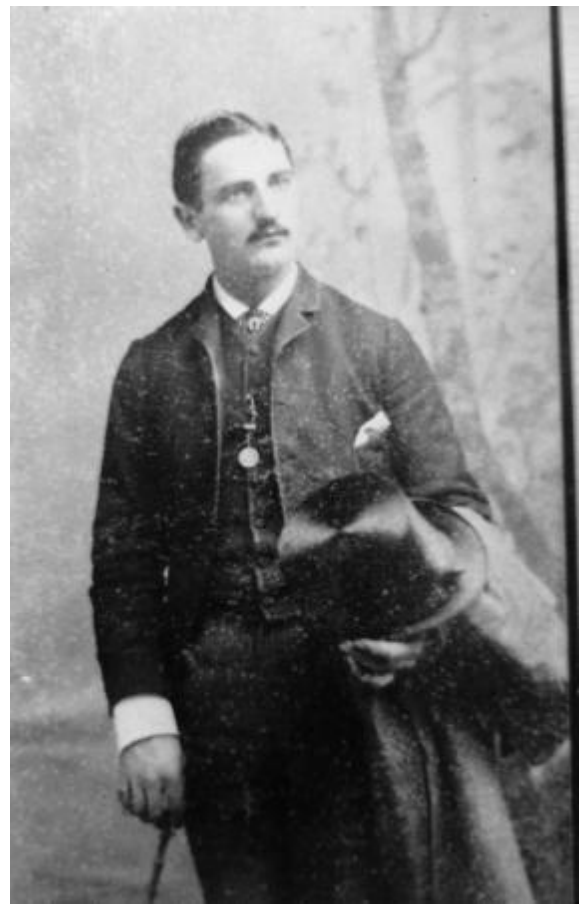

Ill. 10 William Henry Clayton in $\mathbf{1 8 6 0}$

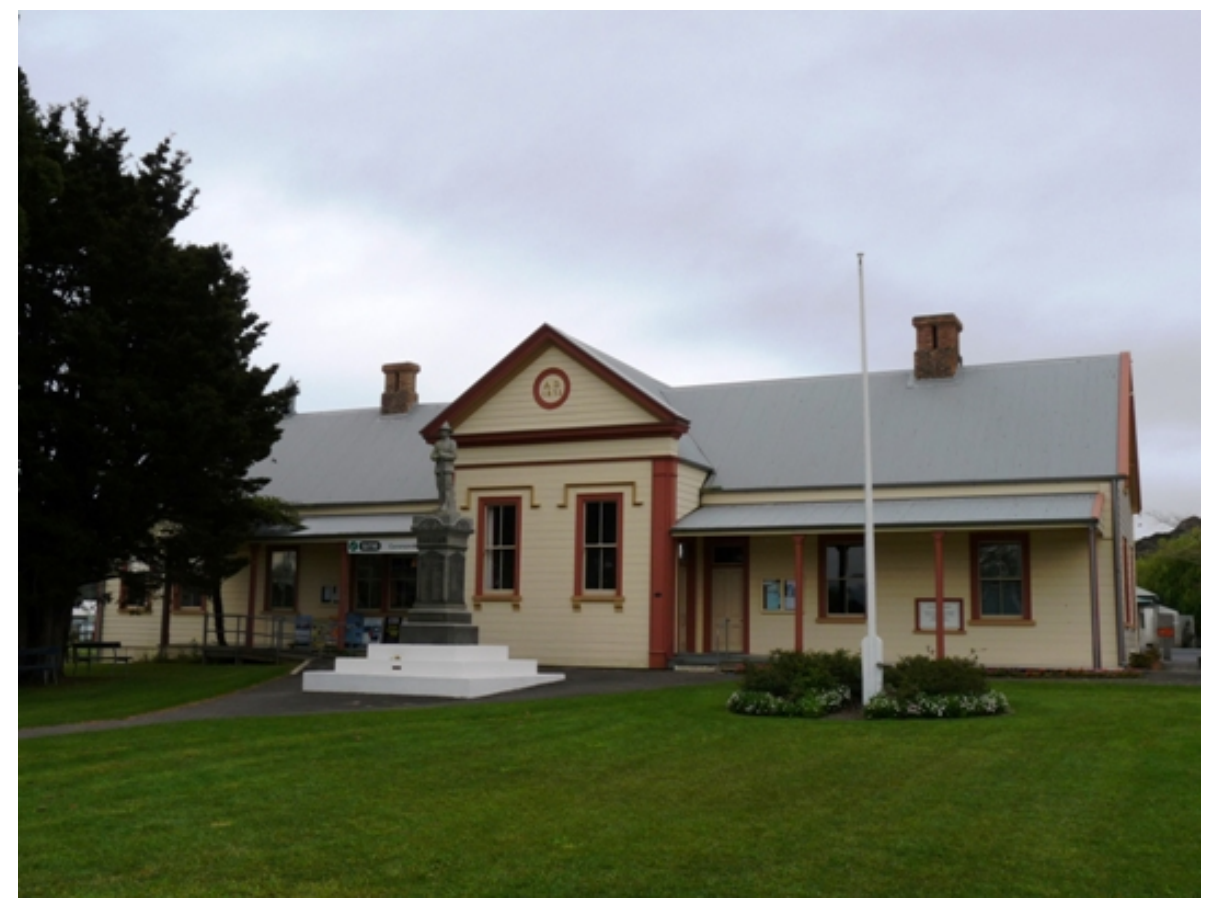

Ill. 11 Former Coromandel Courthouse and Post Office 


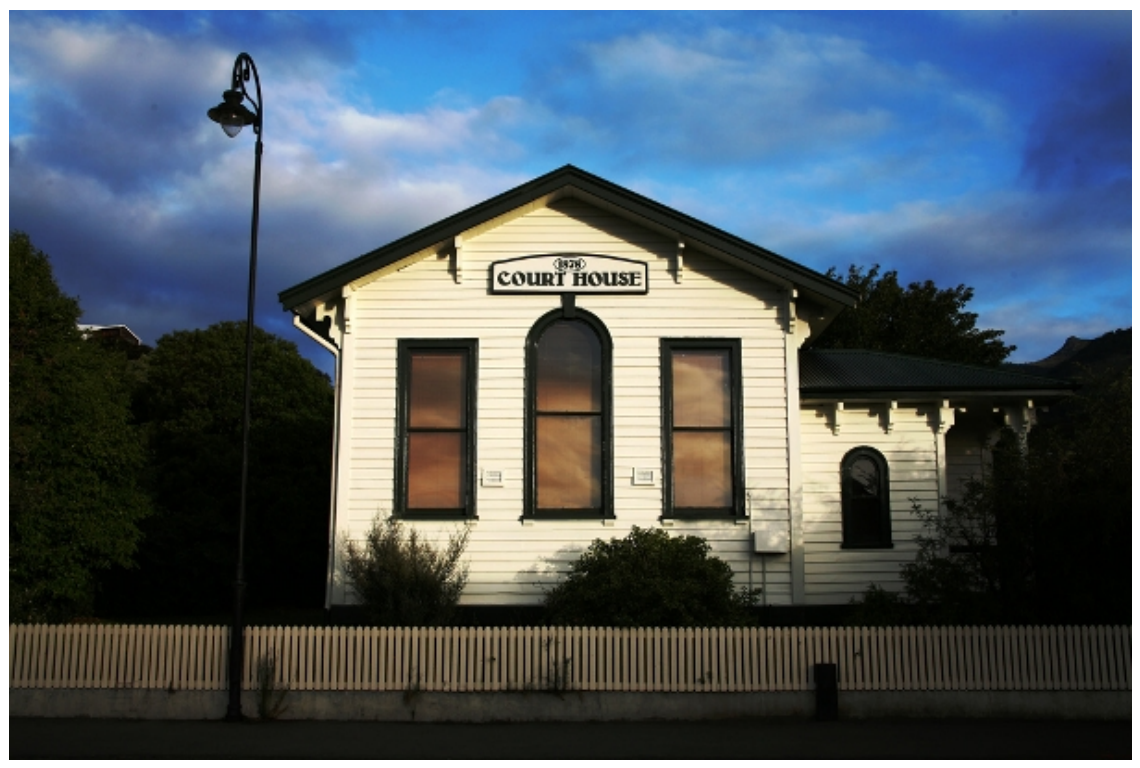

Ill. 12 Former Akaroa Courthouse

During this era courthouses were also designed by private architects, notably Edward Rumsey's Auckland High (formerly Supreme) Court (1865), a courthouse which remains in use today (Ill. 13). The significance of the Auckland High Court building in the evolution of New Zealand's judicial system and its architecture is evident in its NZHPT Register citation:

The High Court is nationally significant as an early public building of Gothic Revival style, unusual in its scale and level of decoration in 1860s New Zealand. It graphically demonstrates the growing power of the state and legal system on a national level, as well as the local importance placed on law and order as Auckland was undergoing transformation soon after the third New Zealand - or Waikato War (1863-1864). [...] The building reveals much about nineteenth-century life through its appearance and layout, including attitudes to justice, the organisation of legal affairs and relationships between the public and the state. The preserved interiors also demonstrate prevailing fashions for decor and nineteenth-century craft techniques. [...] The significance of the building is enhanced by its imposing 
landmark qualities, and by being one of several structures on their original sites in the Waterloo

Quadrant and Symonds Street area. ${ }^{77}$

Pierre Finch Martineau Burrows $(1842$ - 1920) paid tribute to his predecessor William Clayton's Government Building (1876) (Ill. 14) in the former Wellington Supreme Court building (1880) (Ill. 15) by "repeating the use of arched windows in a rusticated ground floor and rectangular windows topped by triangular pediments."778 Burrows' courthouse employed a Victorian neo-classical style, which, compared with Rumsey's Auckland courthouse, parallels the contemporaneous competition in English architecture between advocates of Neo-classical and Gothic Revival styles as the most appropriate for civic architecture. ${ }^{79}$ The Neo-classical Oamaru District Court (1883, designed by local architects Forrester \& Lemon) (Ill. 10) and Gothic Revival Dunedin High/District Court (1902, designed by John Campbell) (Ill. 17) (both still in use as courthouses) also evince this stylistic tension.

Then, as now, there was a marked difference between the architecture of provincial versus urban courthouses. In the late $19^{\text {th }}$ and early $20^{\text {th }}$ centuries provincial courthouses tended to be simple in style and modest in scale and constructed using local materials, particular timber (e.g. Warkworth District Court (1880) (Ill. 18)) while (as noted in relation to the Auckland High Court above) city courthouses tended to make more of a statement about the imposition of colonial government over the fledgling colony.

\footnotetext{
${ }^{77}$ New Zealand Historic Places Trust, "High Court Building, Auckland", http://www.historic.org.nz/TheRegister/RegisterSearch/RegisterResults.aspx?RID=17

${ }^{78}$ Martin, Built for Us, p. 36.

${ }^{79}$ See Paul Jones, "Architecturing Modern Nations: Architecture and the State" in Gerard Delanty and Engin F. Isin (eds.), Handbook of Historical Sociology, London: Sage, 2003, pp. 301-311.
} 


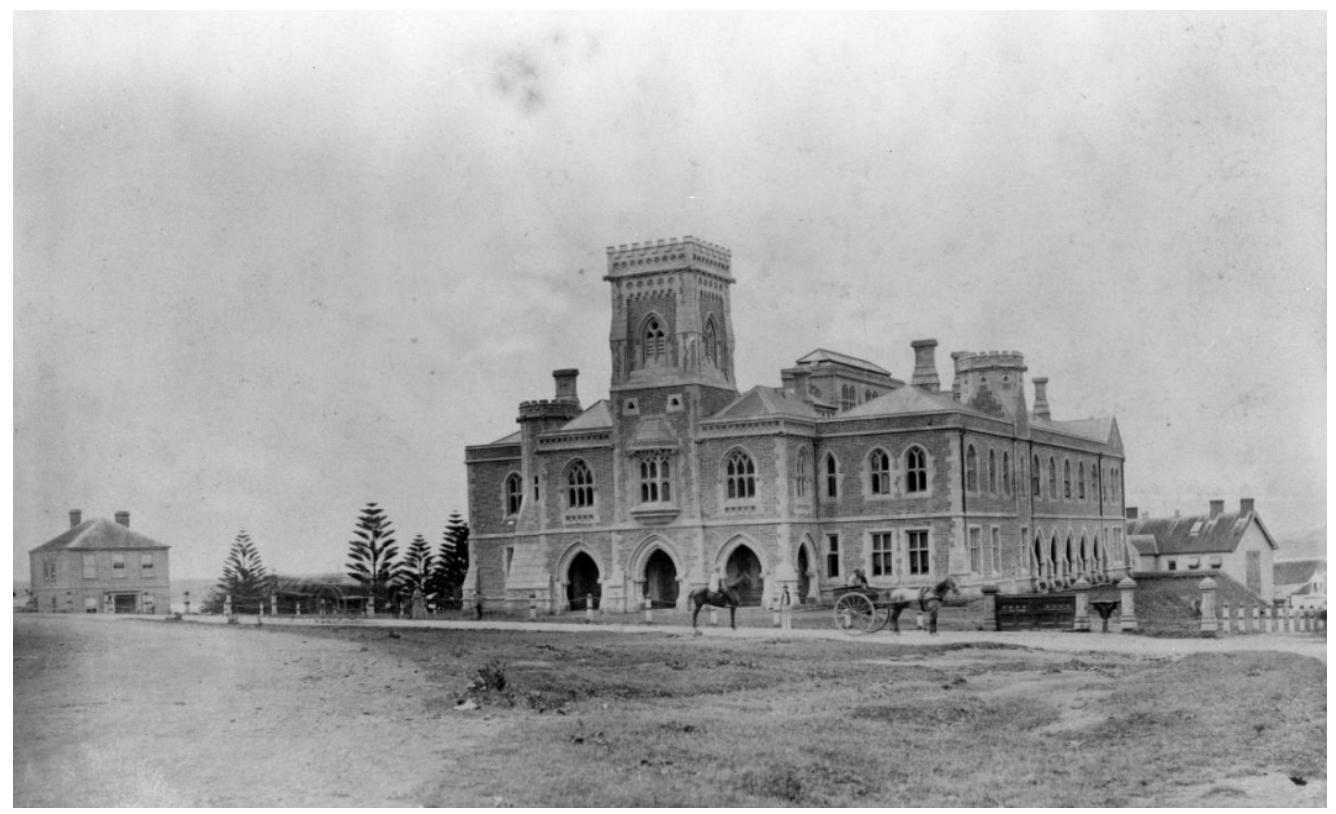

Ill. 13 Auckland Supreme Court

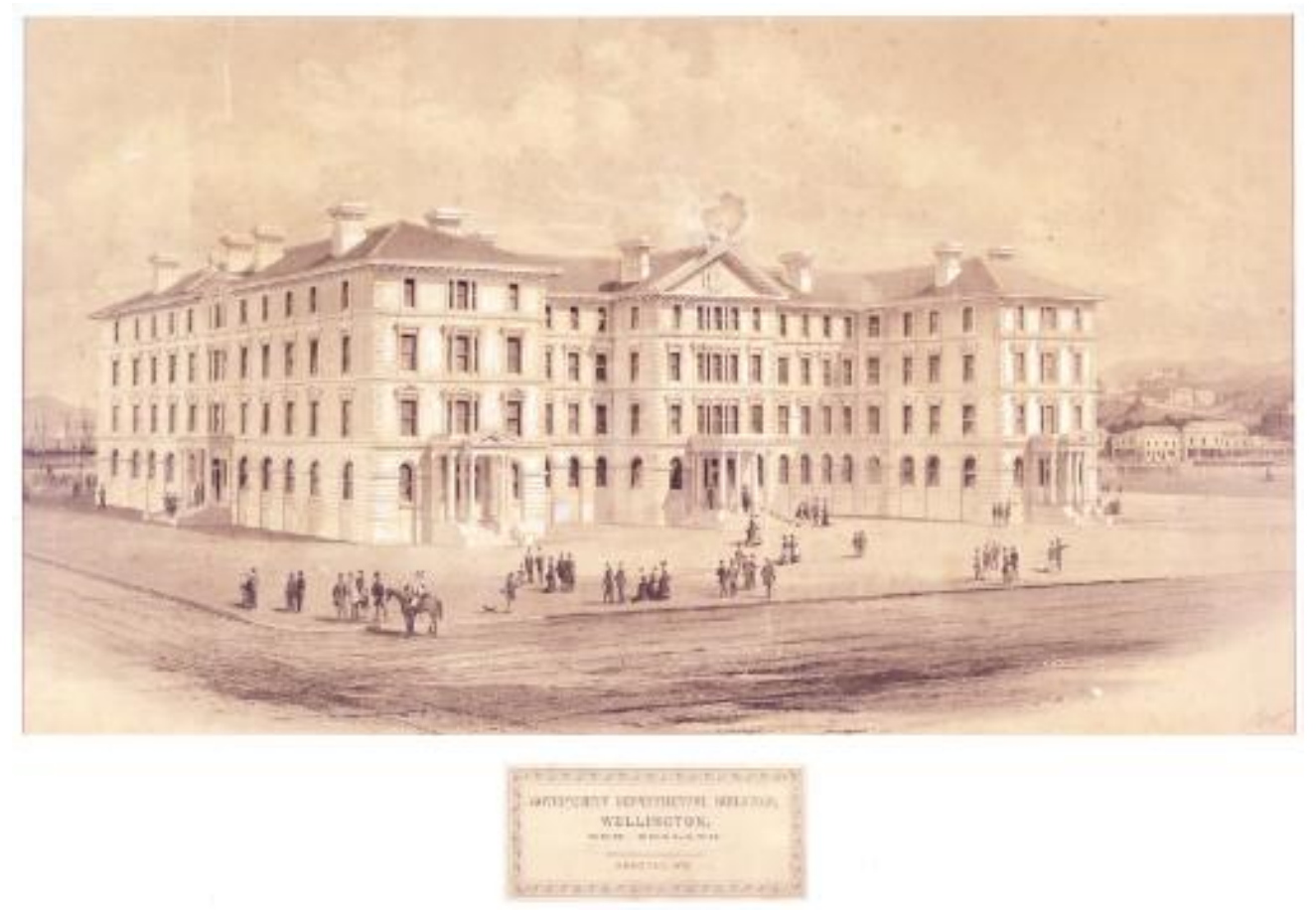

Ill. 14 W. H. Clayton's Government Building 


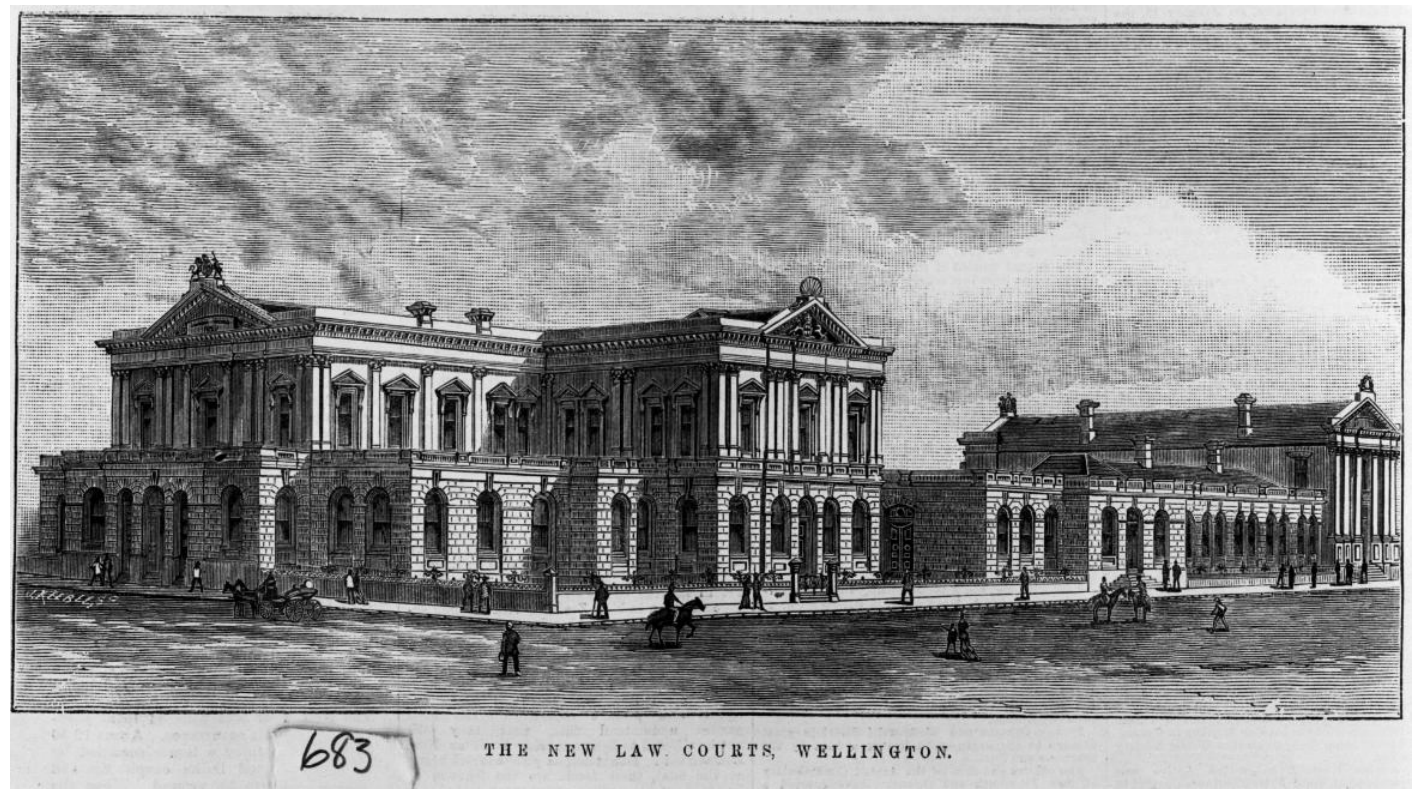

Ill. 15 P. F. M. Burrow's Wellington Supreme Court

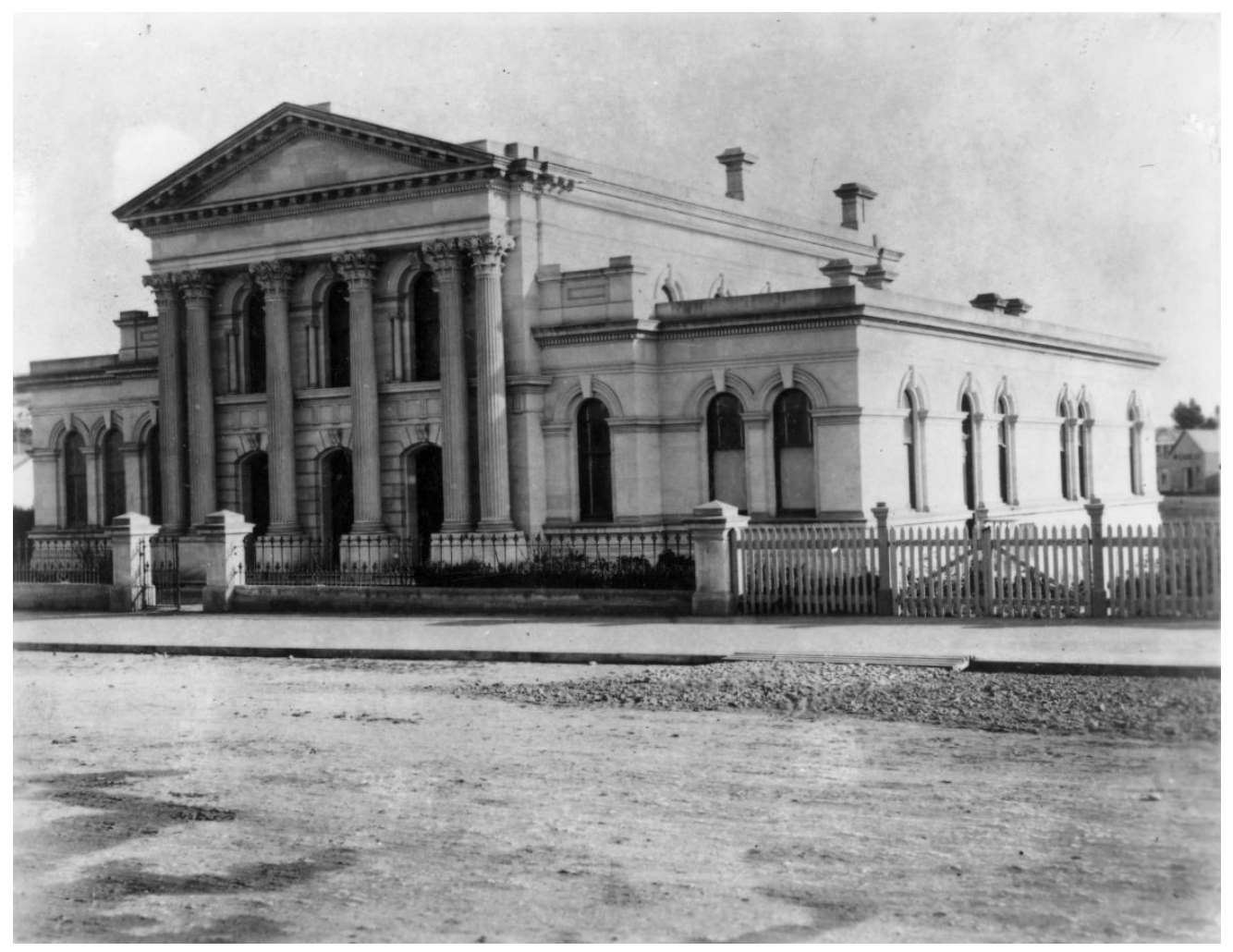

Ill. 16 Oamaru courthouse 
There would appear to be exceptions to that rule, however, for example the grand Waimate (Ill. 19) and Oamaru District Courts (1880 and 1883 respectively) or the original Hamilton District Court (1903) (Ill. 20). An assumption that could use further investigation is that the relative grandeur or simplicity of these courthouses vis-à-vis their present-day operational significance is likely a function of the rise and fall of the districts' economic and political fortunes.

The mix of architectural styles of courthouses up to the turn of the century gave way to a fairly consistent Edwardian Baroque style in the public architecture designed within the Public Works Department under the direction of John Campbell (Government Architect 1909 - 1922) (Ill. 21). Like Clayton, Campbell is credited with the design of a large number of courthouses, both provincial courthouses in either timber or masonry (e.g. the Marton (1897) and Otorohanga (1913) courthouses), and larger, more ornate urban courthouses in stone or plaster-rendered masonry (e.g. the Auckland Magistrates' Court (1913) (Ill. 22)), predominantly in an Edwardian style, with the exception already noted of the Dunedin courthouse. John Mair (1876 - 1959), the first New Zealand-born Government Architect, designed the Hamilton courthouse (1930) (Ill. 23), which was executed in his customary “severely restrained 'stripped classical' manner, with precisely controlled Art Deco ornamentation." ${ }^{\prime 0}$ This approach is also evident in Mair's Blenheim (1937) (Ill. 24), Ashburton (1938) and Invercargill (1941) courthouses, all of which evince architectural influences that extend for the first time in New Zealand judicial architecture beyond the English frame to continental Europe and America.

${ }^{80}$ Martin, Built for Us, 115, 128. 


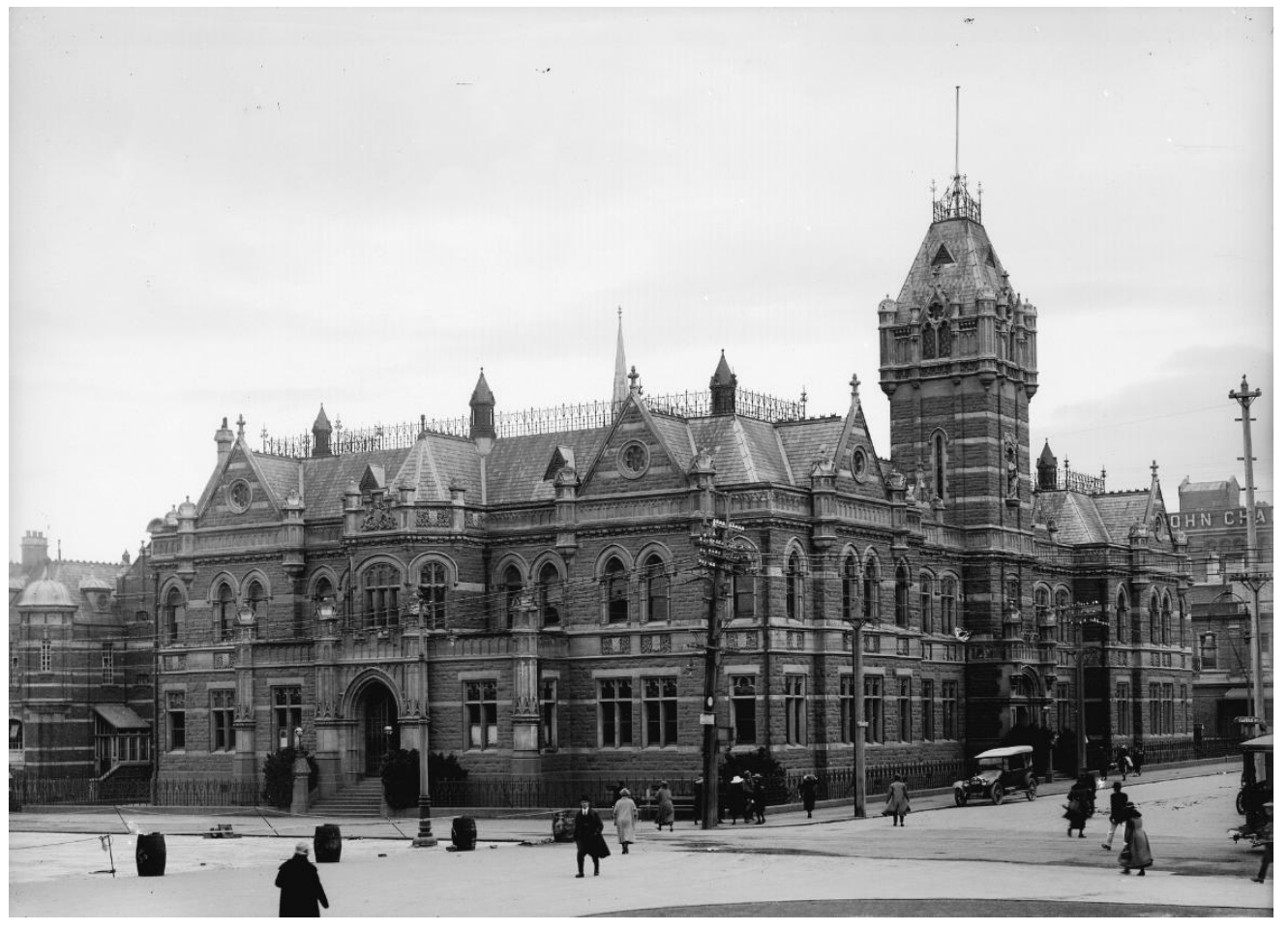

Ill. 17 Dunedin courthouse

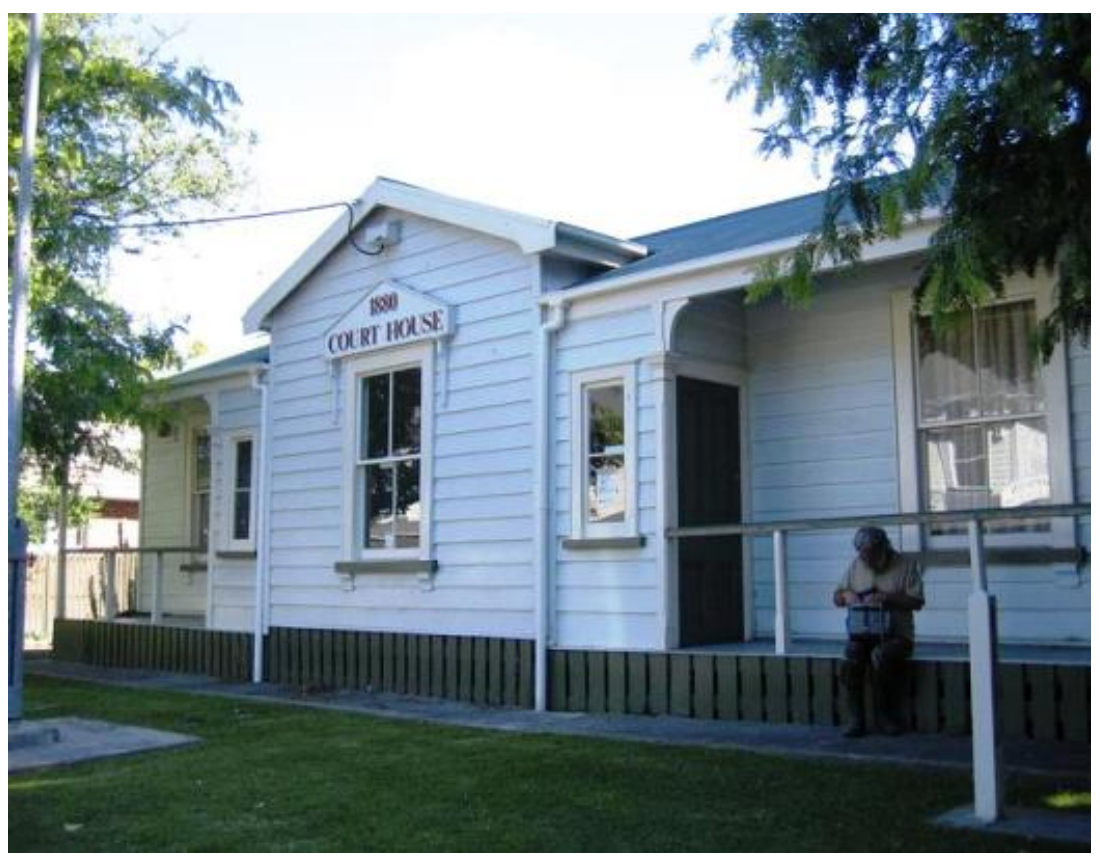

Ill. 18 Former Warkworth courthouse 


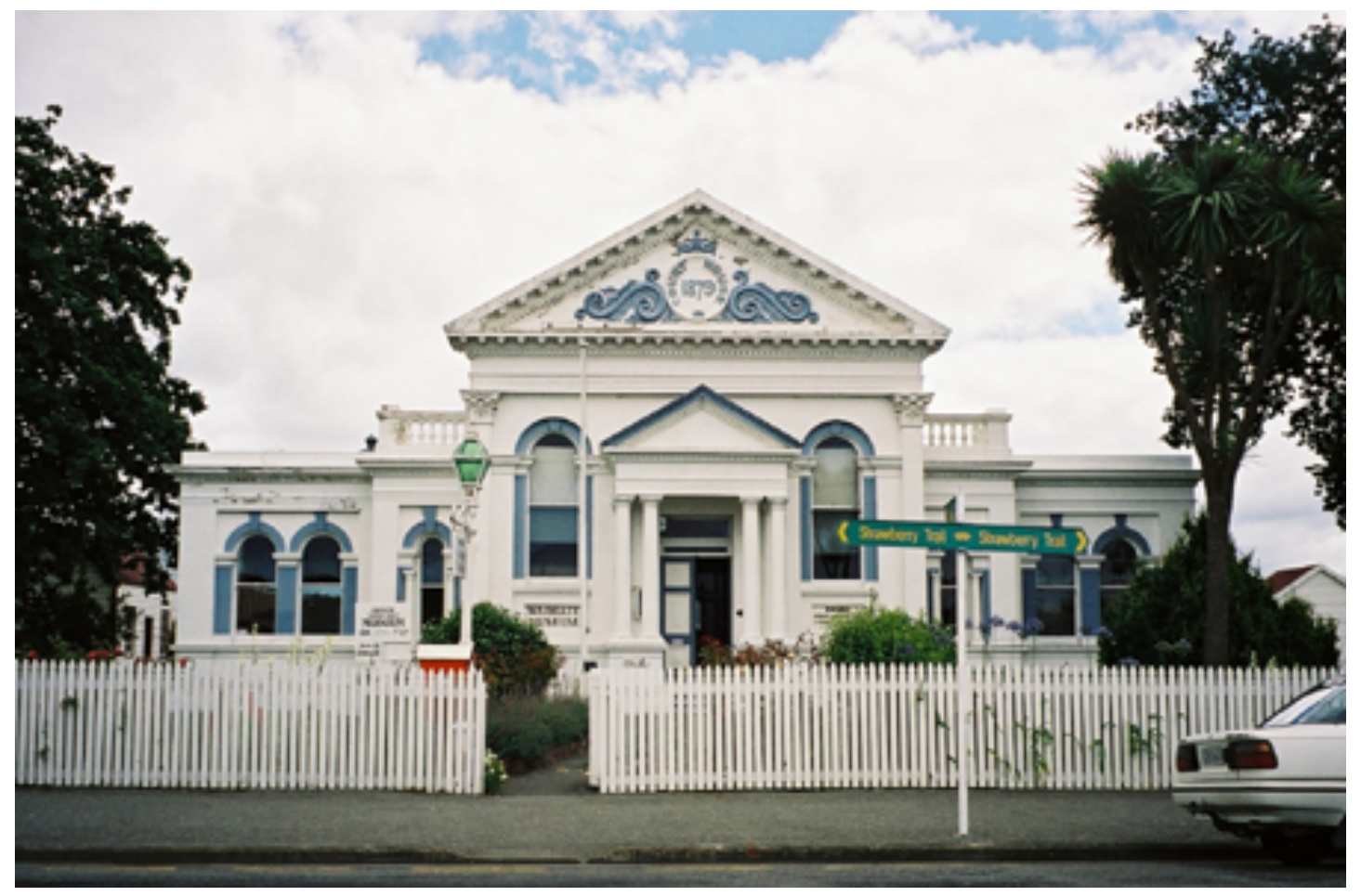

Ill. 19 Former Waimate courthouse

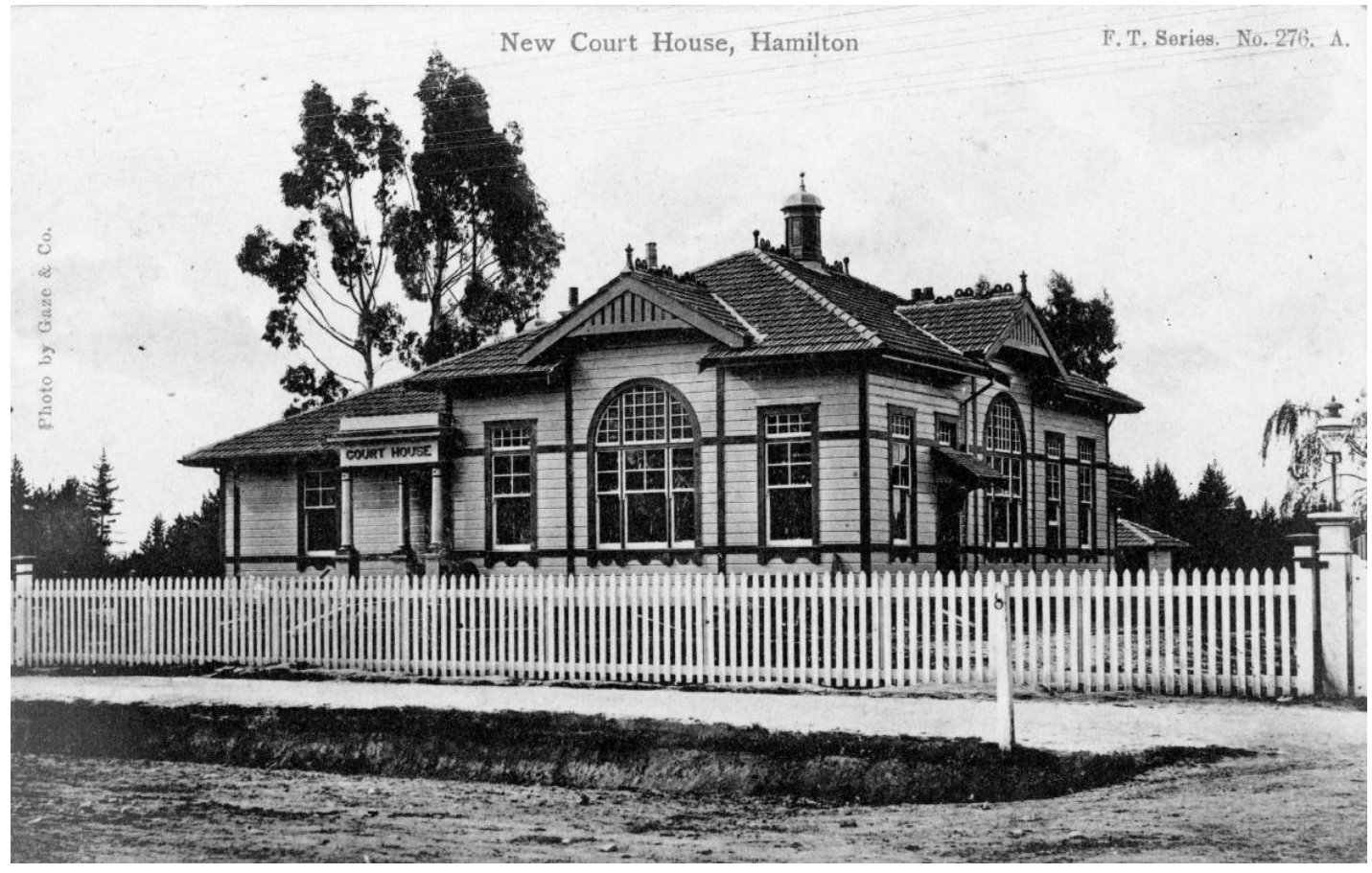

Ill. 20 Former Hamilton Courthouse

60 
By distinct contrast with the pre-WWII period, there is a dearth of knowledge relating to New Zealand judicial architecture after the 1940s. There was an explicable lull in the design and construction of new courthouses in New Zealand during the war era while the immediate post-war period saw construction activities restricted to the renovation and expansion of existing courthouses to meet contemporary operational requirements. It wasn't until the 1960s that new courthouses were opened, predominantly in reinforced concrete, steel and glass, stylistically investigative of moment-frame structural expressionism and architectural functionalism. ${ }^{81}$ Despite recent attention in New Zealand architectural historiography surrounding modernist influences, courthouses which identifiably respond to such influences do not appear to have received much consideration. ${ }^{82}$ Gatley's Long Live the Modern gives passing mention to the Rotorua M ori Land Court (1963), Nelson (1974) (Ill. 25) and Palmerston North courthouses (1988). ${ }^{83}$

These references make note of the influence of Ministry of Works architects on courthouse design, an influence which Stacpoole and Beaven note

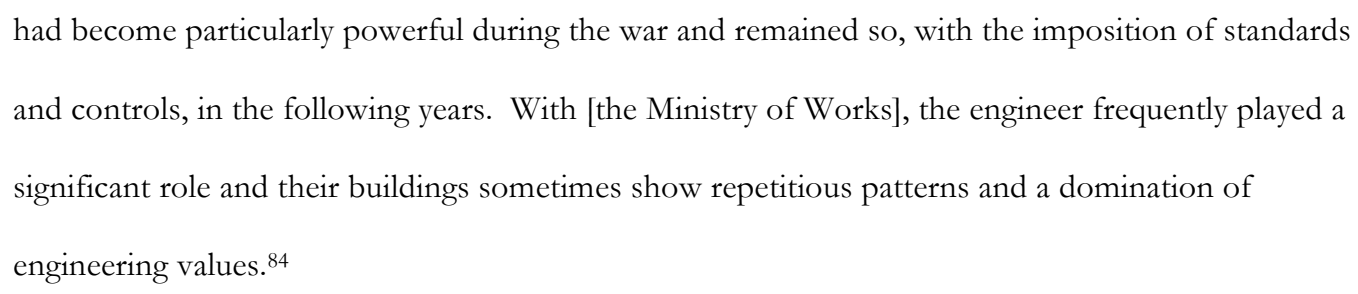

\footnotetext{
${ }^{81}$ See John Stacpoole \& Peter Beaven, Architecture 1820 - 1970 (Wellington: Reed, 1972), 75.

${ }^{82}$ See for example Julia Gatley (ed.), Long Live the Modern: New Zealand's New Architecture 1904 - 1984 (Auckland: Auckland University Press, 2008) and Justine Clark and Paul Walker, Looking for the Local: Architecture and the New Zealand Modern (Wellington: Victoria University Press, 2000).

${ }^{83}$ See Gatley, Long Live the Modern, 126, 154, and 216.

${ }^{84}$ Stacpoole \& Beaven, Architecture 1820 - 1970, 75-6.
} 


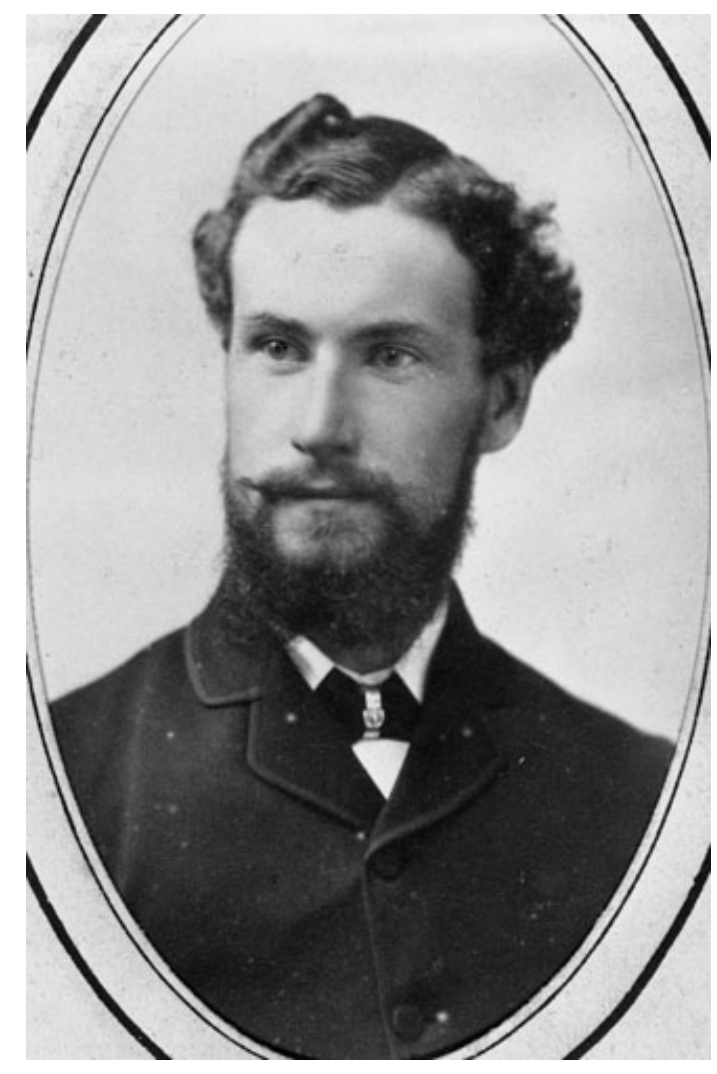

Ill. 21 John Campbell

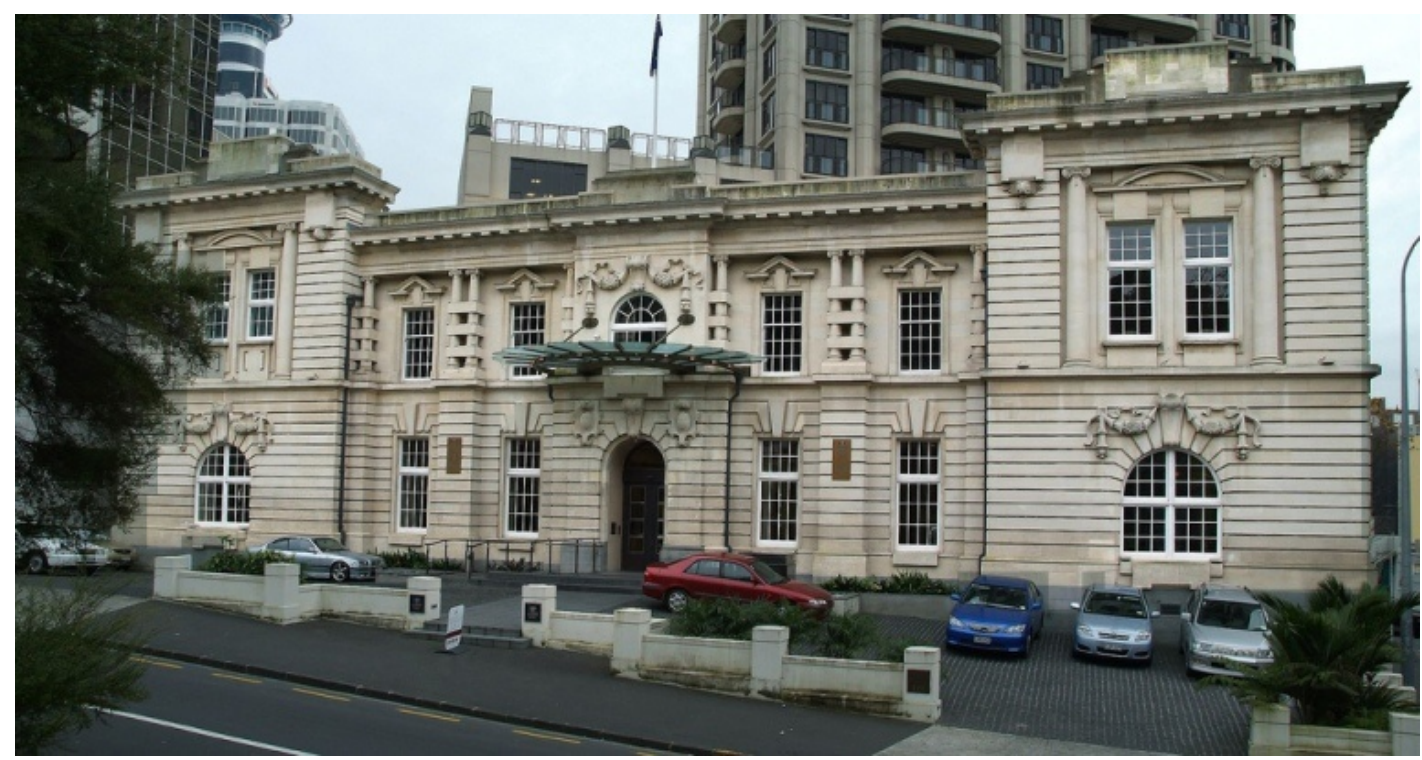

Ill. 22 Former Auckland Magistrates Court 


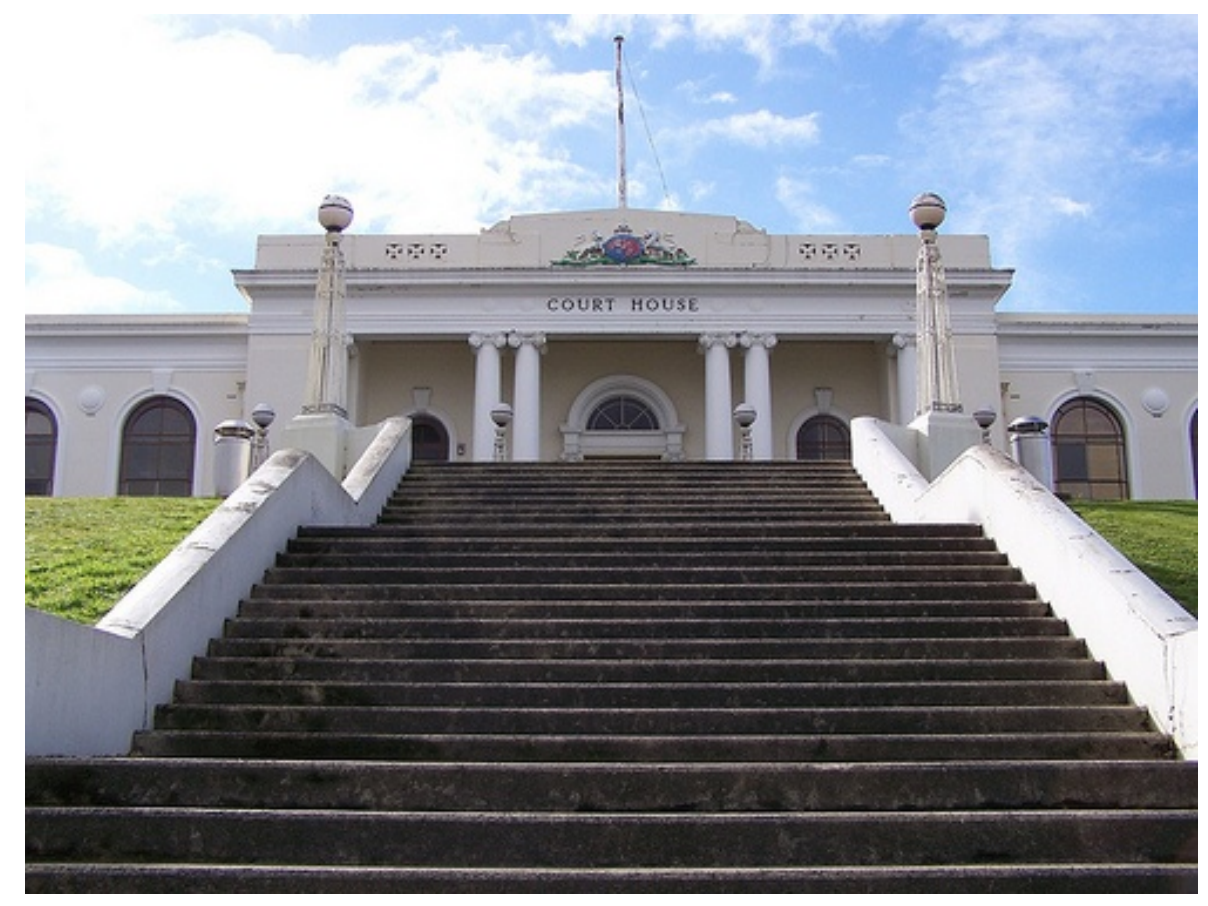

Ill. 23 Former Hamilton Courthouse

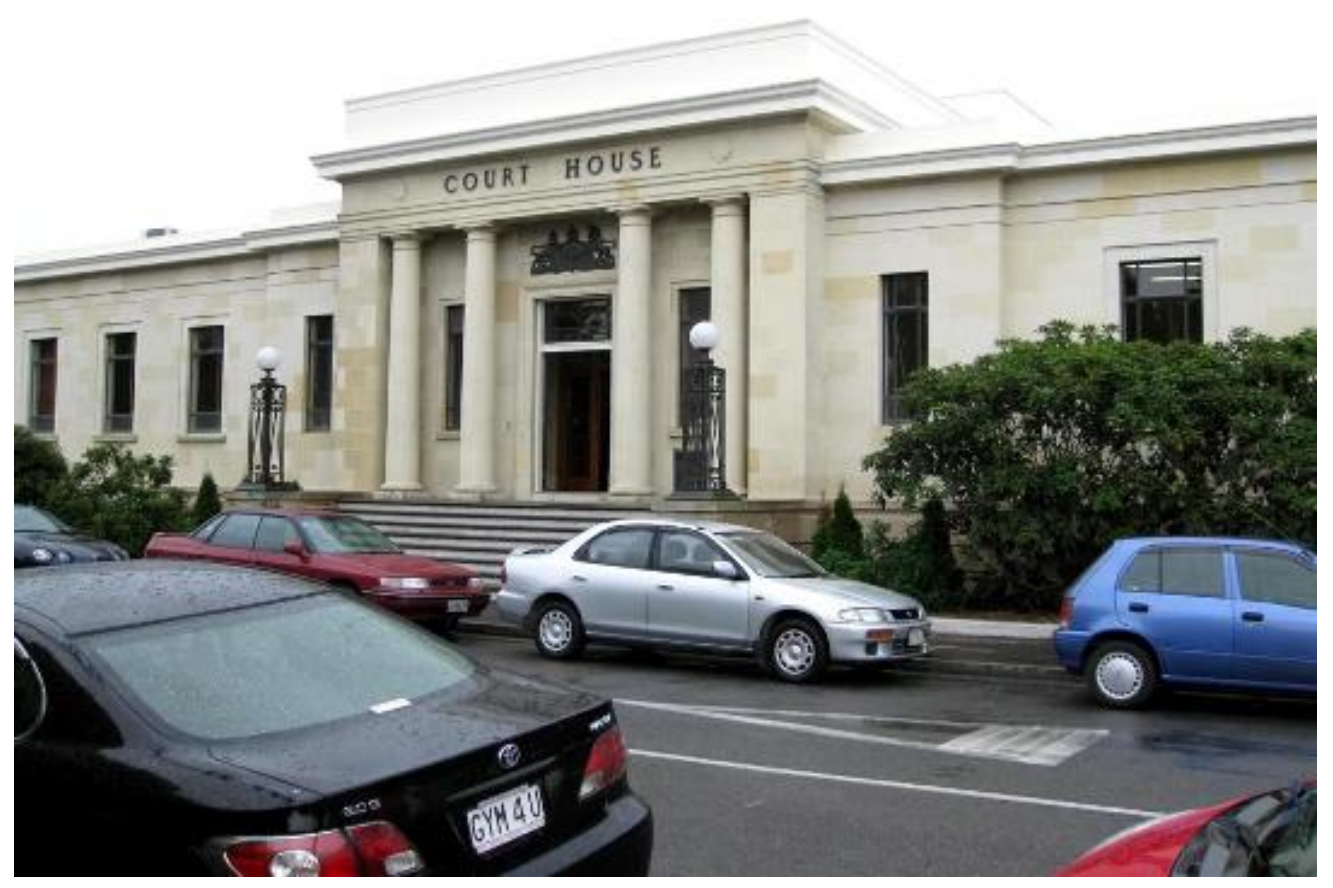

Ill. 24 Blenheim Courthouse 
This aesthetic is particularly evident in the use of concrete construction, prefabrication, precasting and moulding techniques in courthouses as geographically and temporally diverse as the Taumarunui District Court (1970), Marton District Court (1975), and Christchurch Courthouse (1989) (Ill. 26). ${ }^{85}$

The legibility of the courthouse typology within the urban fabric diminished significantly from the 1980s with a shift to more "commercial" architectural styles. This approach to judicial architecture is best exemplified by the Auckland District Court (1988) (Ill. 27). Some courts in this era (particularly tribunals such as the Environment and Employment courts) were located within existing commercial properties; some even assumed a suburban identity, such as the Pukekohe District Court (1993) (Ill. 28). Taking this diminished legibility into account, it seems likely that the renovations of a number of courthouses in the early $21^{\text {st }}$ century have intentionally sought to reinforce (or even re-establish) the presence of the local courthouse within the social fabric of the communities they serve, as seen in the renovations and revitalisations of the Gisborne Courthouse (2004), the Hastings District Court (2009) (Ill. 29), and Timaru Courthouse (2011) (Ill. 30).

New varieties of judicial architecture have also begun to emerge in the $21^{\text {st }}$ century, such as the Ruatoria Hearing Centre (2002) (Ill. 31), which evinces a strong architectural response to the interplay of its judicial function and the community it serves. It is suggested that the Supreme Court complex's expressions of judicial aspirations similarly evince a reassertion of the public persona of the courthouse in New Zealand.

\footnotetext{
85 See Gatley, Long Live the Modern, p. 154, and Terence Hodgson, Looking at the Architecture of New Zealand (Wellington: Grantham House, 1990), 86.
} 


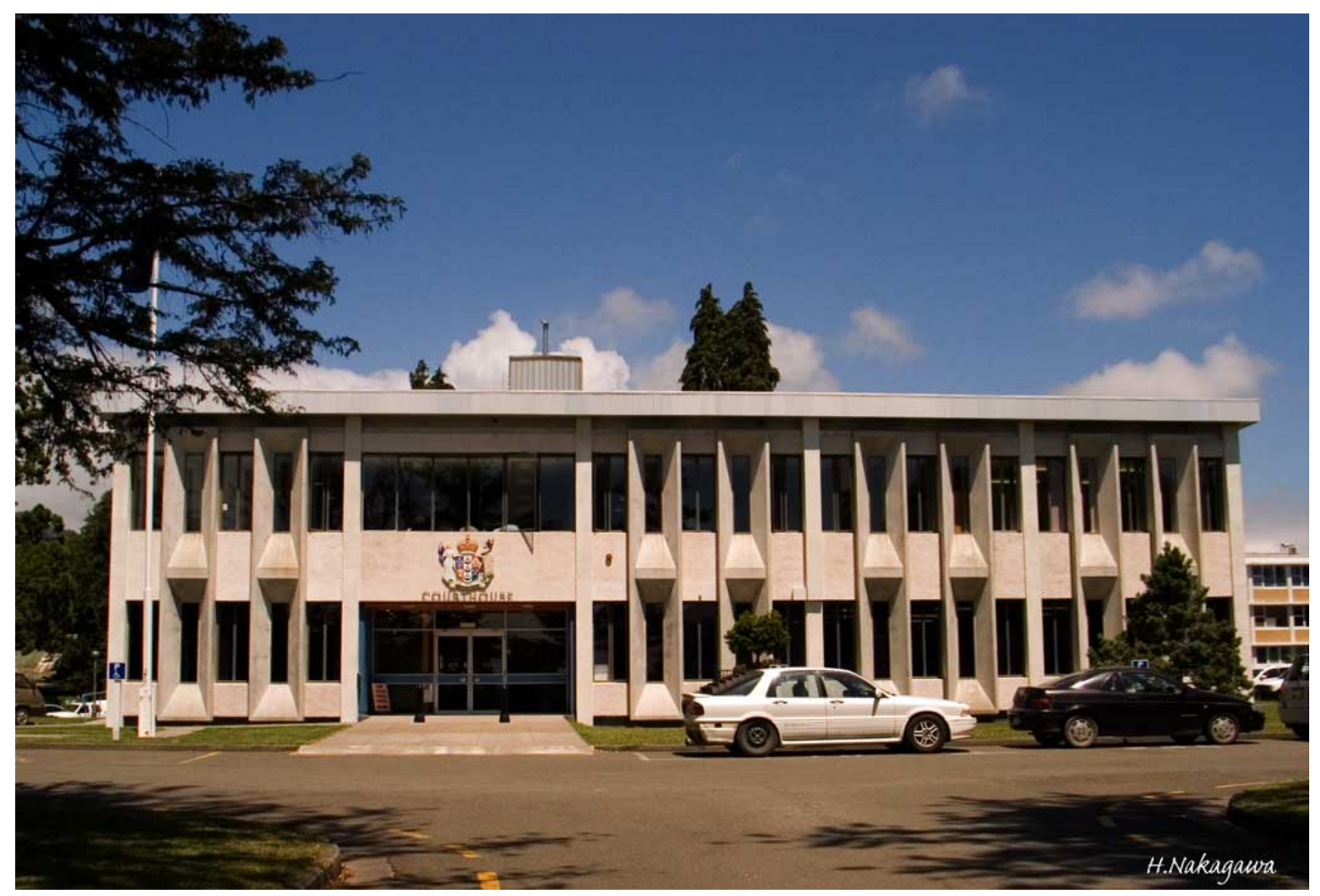

Ill. 25 Nelson Courthouse (original)

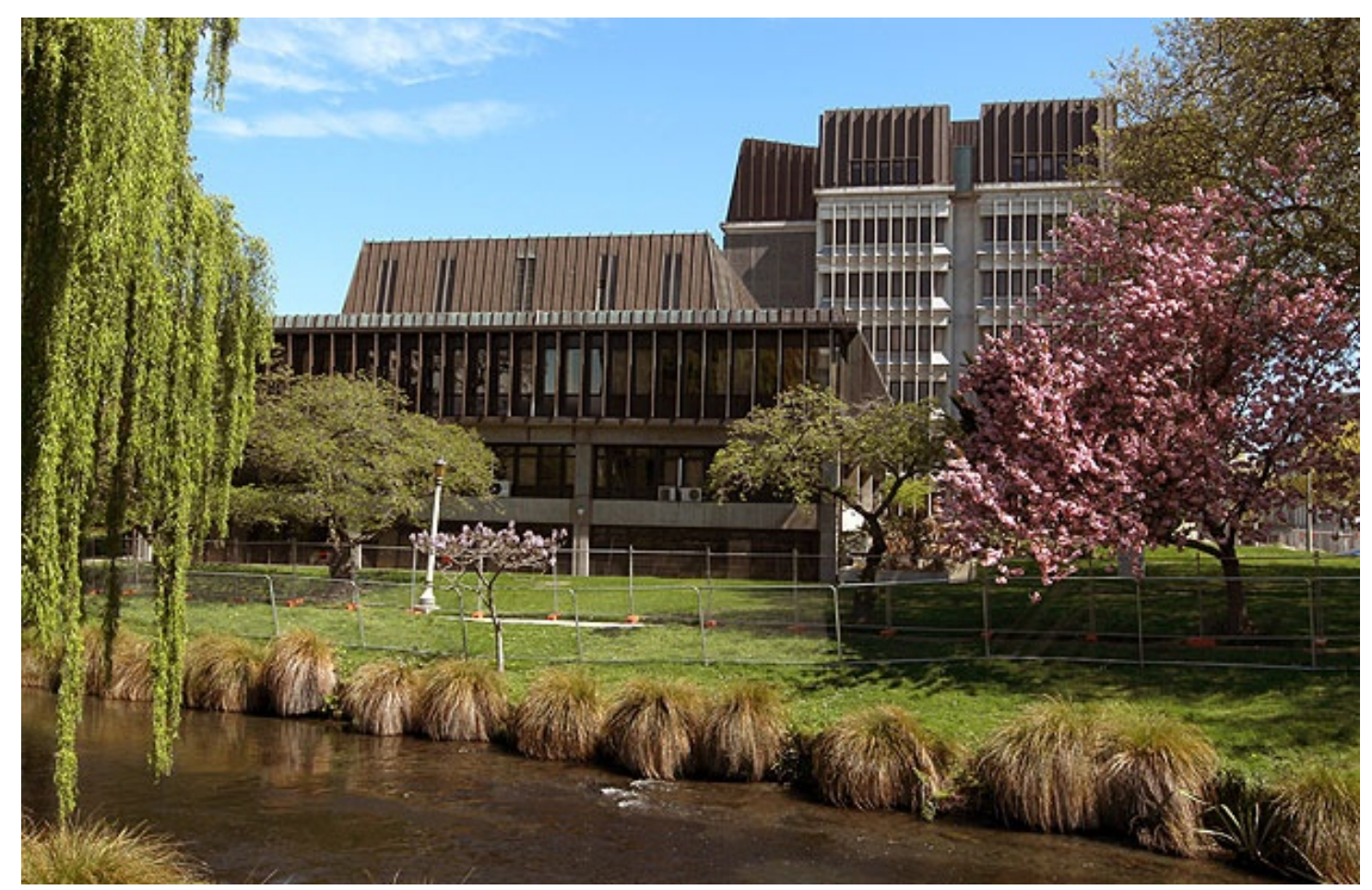

Ill. 26 Christchurch Courthouse 


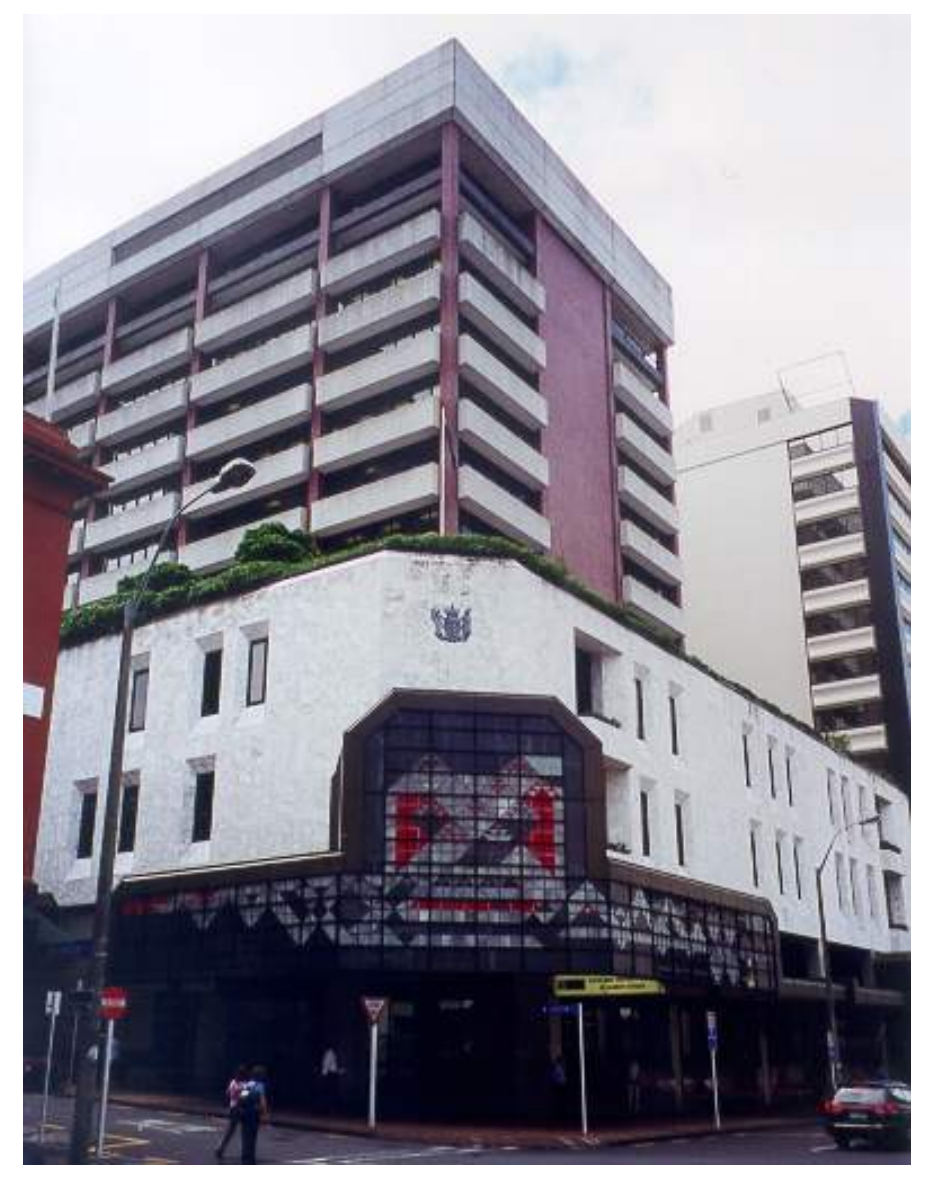

Ill. 27 Auckland District Court

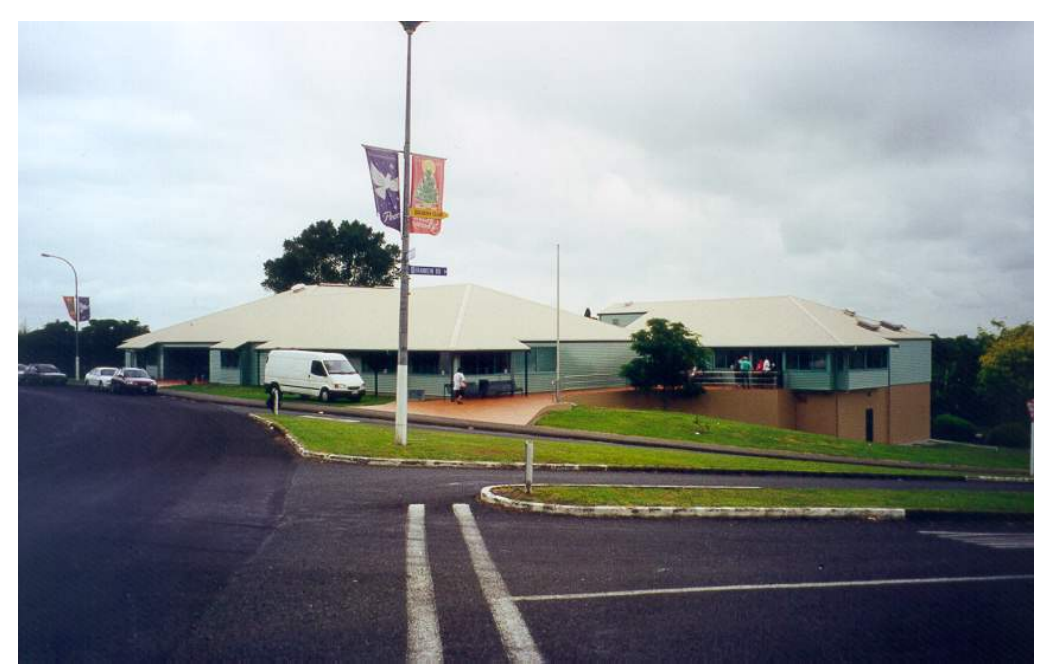

Ill. 28 Pukekohe District Court

66 
For all the change that has occurred in New Zealand judicial architecture since 1840, one aspect has seen very little evolution: courtroom planning. It is significant that while courthouses have come to evince local stylistic influences externally, the layout of the courtroom in New Zealand judicial architecture which was also imported as part of the English precedent has been altered very little since (Ill. $32 \& 33)$. This arrangement is steeped in centuries of history and tradition and (despite research illustrating the shortcomings of traditional planning in judicial proceedings ${ }^{86}$ ) seems likely to persist in New Zealand judicial architecture. As will be discussed in Chapter VI, however, the Supreme Court building is illustrative of how courtroom planning might evolve in New Zealand in the future.

\section{Summary}

The New Zealand judicial system follows in direct descent from the English system, both institutionally and architecturally, in style and substance. New Zealand's judicial system developed to meet the needs of the nation as required, evolving from a single court (the then Supreme Court) into a complex hierarchy of tribunals, trial courts and courts of appeal. Similarly, New Zealand's early judicial architecture predominantly referenced English courthouse design until the post-WWII period when more "rational" international styles were appropriated. Towards the end of the $20^{\text {th }}$ century, however, courthouse design began to respond to international architectural shifts to better represent regional perspectives in architecture. The fundamental planning of the courtroom has remained closely tied to tradition common law models world however.

\footnotetext{
${ }^{86}$ See for example Louis G. Redstone, Institutional Buildings. Architecture of the Controlled Environment (New York: McGraw-Hill, 1980).
} 


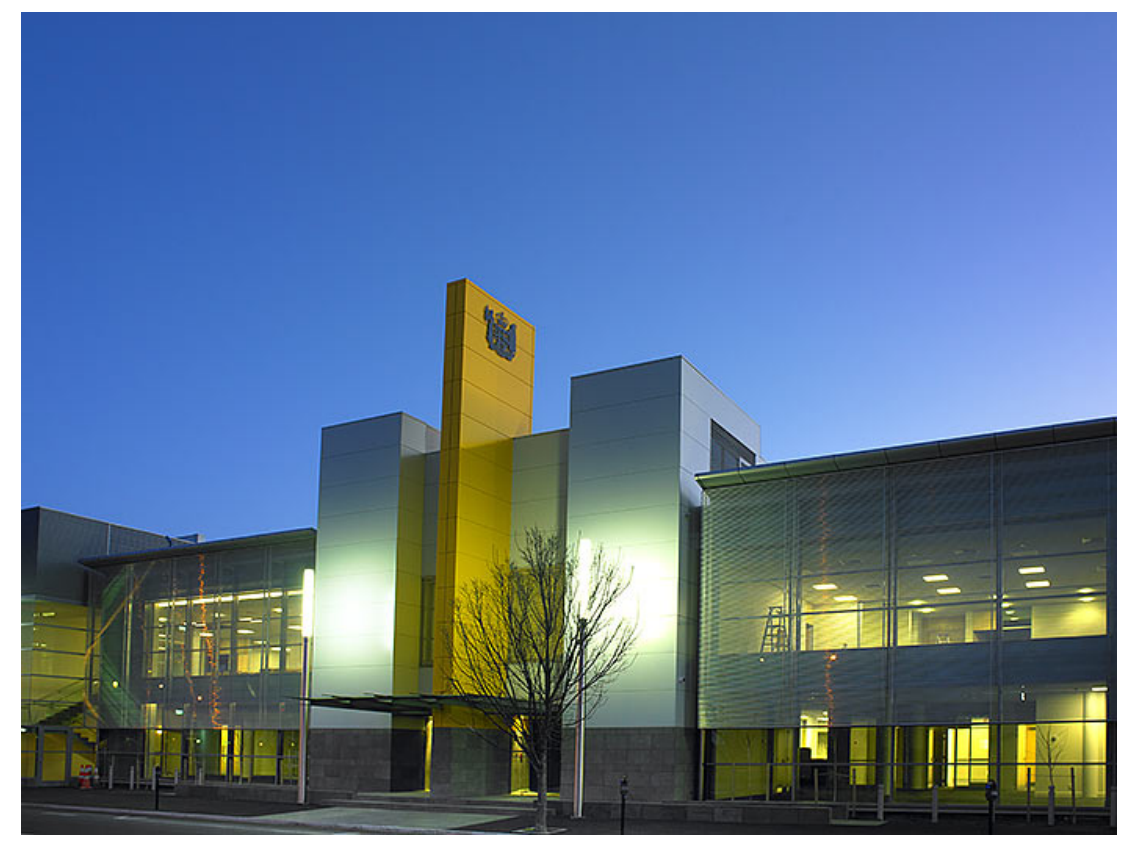

Ill. 29 Hastings Courthouse

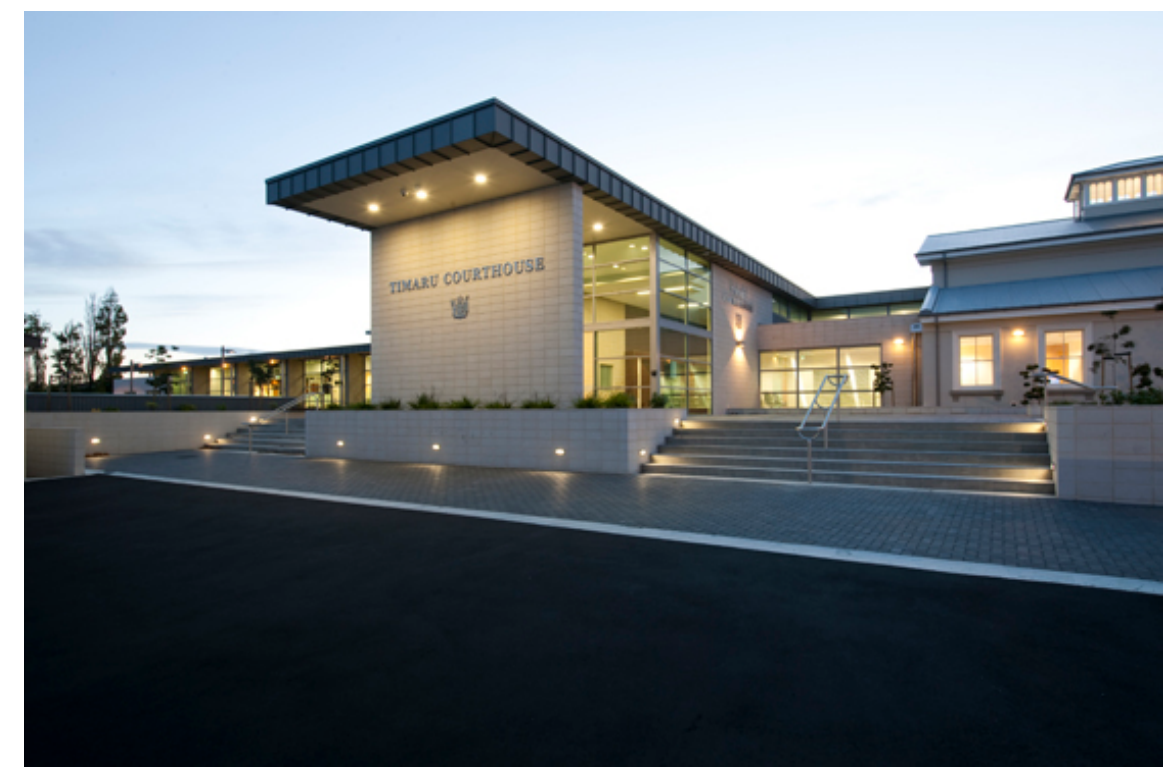

Ill. 30 Timaru Courthouse 


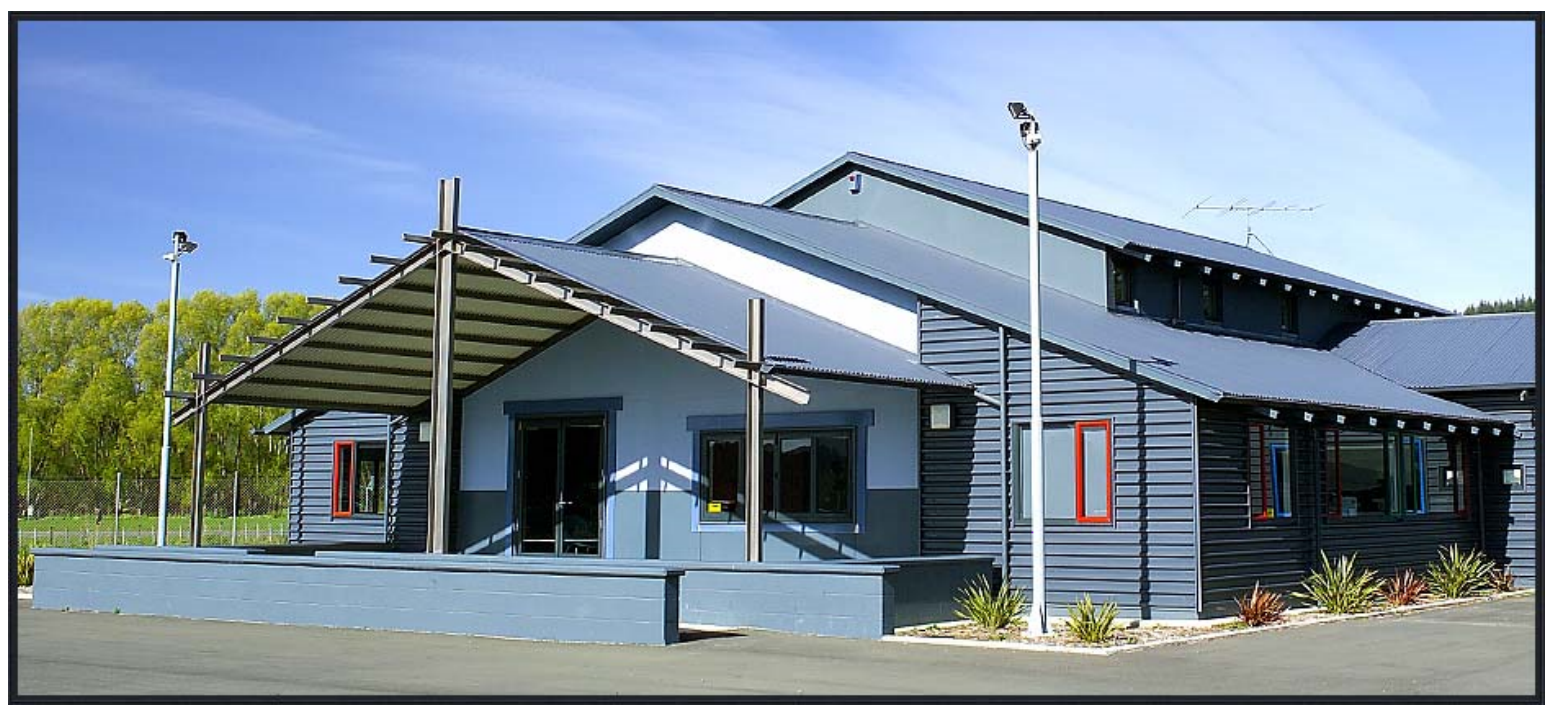

\section{Ill. 31 Ruatoria Hearing Centre}

In the same era, a focus on a more indigenous perspective also became part of the political rhetoric regarding the structure and content of New Zealand's judicial system. While the Privy Council had served at the apex of New Zealand's judicial system from the cession of sovereignty to the British Crown in 1840, since the 1970s there was a move to patriate New Zealand's court of final appeal, resulting in reform of the judicial system in the early 2000 s which saw the establishment in 2004 of the New Zealand Supreme Court. The Supreme Court represents one of the three branches of Government (the others being the executive and legislature) and has a fundamental constitutional responsibility for maintaining the rule of law in New Zealand. The Treaty of Waitangi, considered by many to be New Zealand's founding document, is a unique and fundamental feature of New Zealand's constitutional arrangements and remains a vibrant force in New Zealand's justice system today and into the future. 


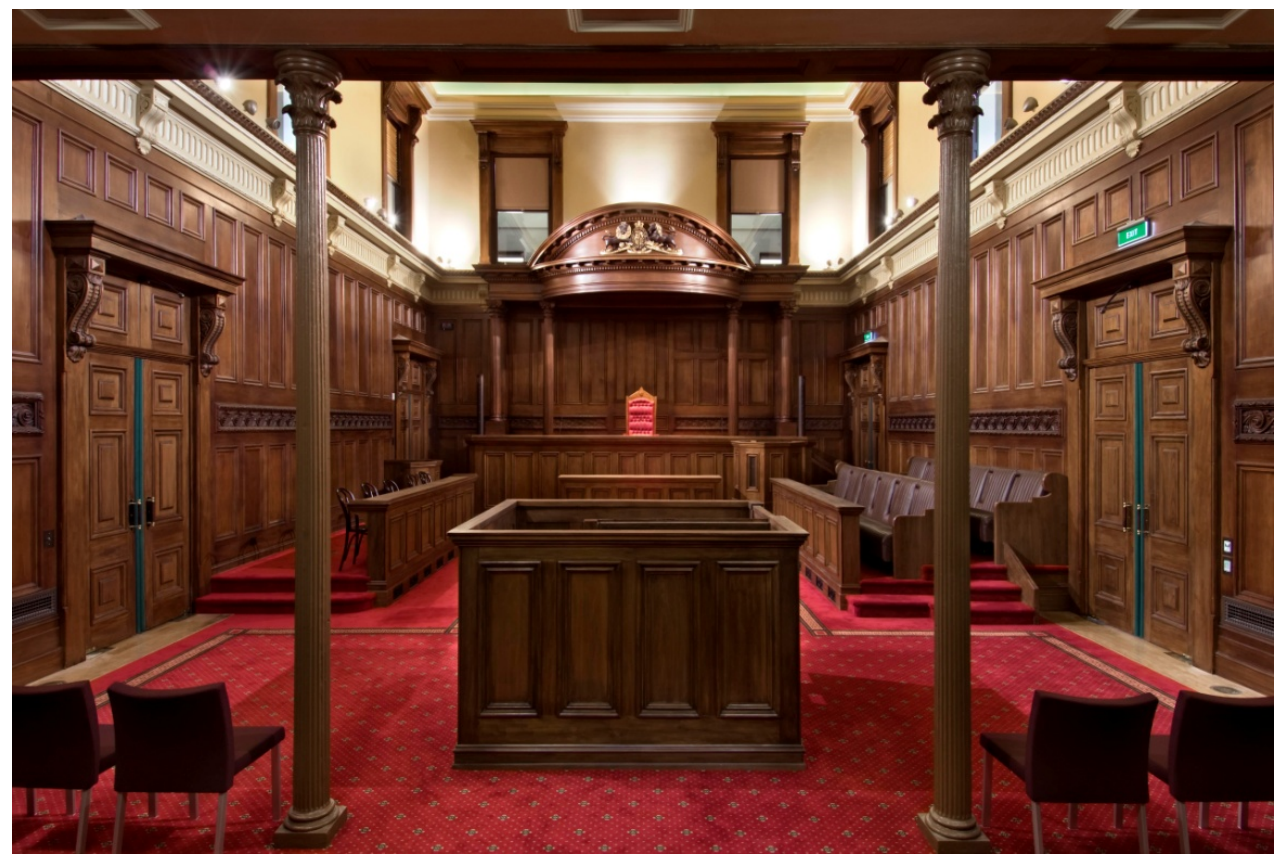

Ill. 32 No. 1 Courtroom, OHCB

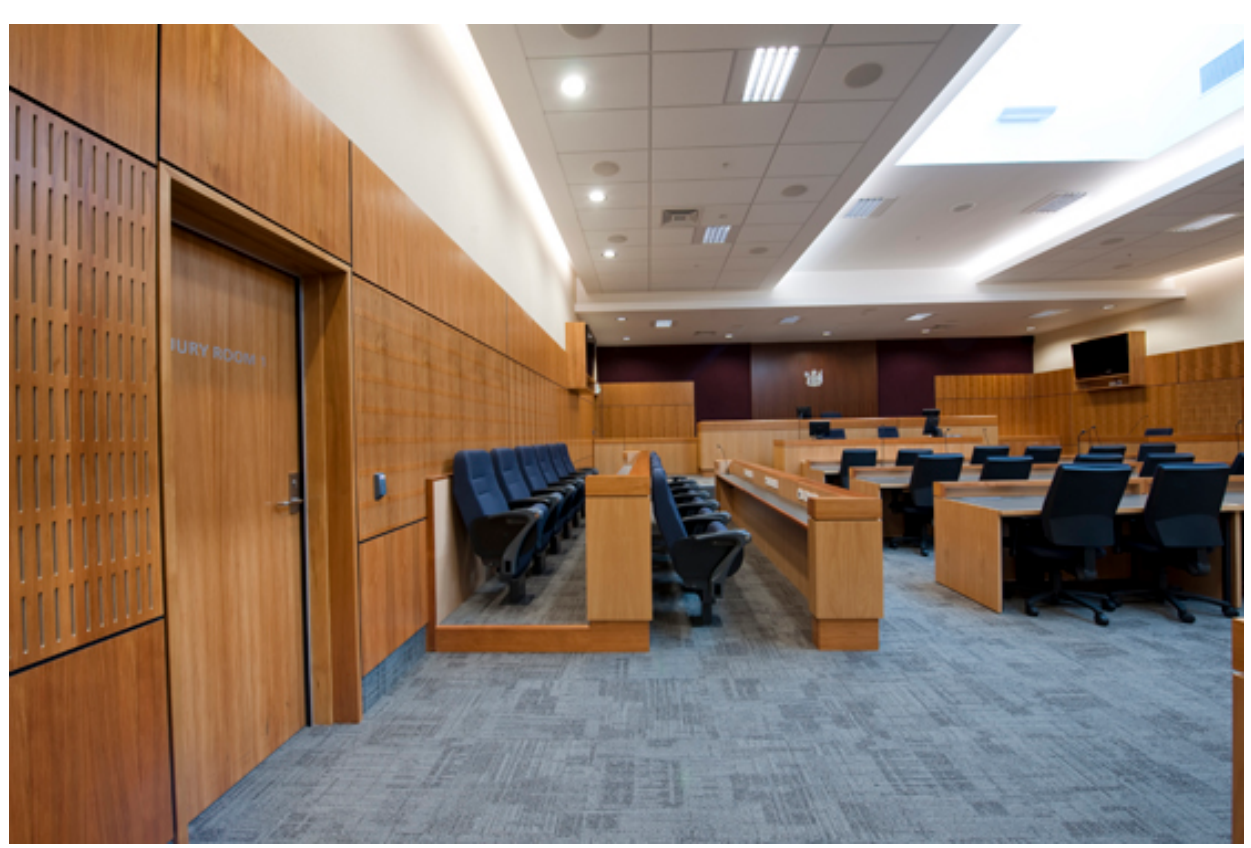

Ill. 33 Courtroom, Timaru Courthouse 
III.

\section{Expressive Meaning in Judicial Architecture}

Chapter III aims to provide some theoretical context to this study. In particular, Chapter III positions this study in relation to Charles Goodsell's work on the social meaning of civic architecture and introduces relevant concepts relating to the political use of architectural symbolism grounded in the work of Murray Edelman, Harold Lasswell, Rudolf Arnheim and Joseph Gusfield. Studies by Antoine Garapon and the Law Reform Commission of Western Australia on the expressive role judicial architecture plays within the justice system further inform that understanding. The work of these scholars underpins the assumption of this study that the architecture of the Supreme Court complex legibly expresses the aspirations of the New Zealand justice system at the beginning of the $21^{\text {st }}$ century.

Considering the constitutional importance of the judiciary in democratic societies, judicial architecture seems to have received limited and sporadic academic attention as an architectural typology. Increasingly, however, attention is being paid to how the judicial environment affects the process and administration of justice. Areas of prior research identified in the course of this study include the spatial and technical requirements of courthouses $;{ }^{87}$ historical surveys of the courthouses of a geographic area $;{ }^{88}$ case studies of

\footnotetext{
${ }^{87}$ E.g. Glenn R. Winters, ed., Courthouses and Courtrooms: Selected Readings, Chicago: American Judicature Society, 1972; and Michael Griebel \& Todd S. Phillips, "Architectural Design for Security in Courthouse Facilities" Annals of the American Academy of Political and Social Science Vol. 576 Courthouse Violence: Protecting the Judicial Workplace (July 2001), 118-131.

${ }^{88}$ E.g. Martha J. McNamara, From Tavern to Courthouse: Architecture \& Ritual in American Law, 1658-1860 (Baltimore: John Hopkins University Press, 2004).
} 
specific courthouses $;{ }^{89}$ the psychological implications of courthouse design; ${ }^{90}$ conservation studies of historic courthouses $;{ }^{91}$ symbolism in judicial architecture $;{ }^{92}$ and courthouses as buildings within the oemvre of a particular architect or architectural practice. ${ }^{93}$ No focused consideration of judicial architecture in New Zealand per se was found. It is suggested that this lack of study is not because to do so would lack value, but rather that this field is generally underexplored in the canon of architectural analysis and critique. Mulcahy suggests that this absence of research can be explained (at least from the perspective of the legal profession) by the legal system's obsession with the word:

When we teach our students about law we do so through the medium of the written judgment or transcript as though these give a complete account of why a case is decided in a particular way. [...]. In this sense lawyers have traditionally looked upon space within the court as a depoliticized surface. The conceptualization of the legal arena limits our appreciation of how spatial dynamics can influence what evidence is forthcoming, the basis on which judgments are made and the confidence that the public have in the process of adjudication..$^{94}$

It is suggested that many architectural critics may be reluctant to engage with judicial architecture due to the esoteric nature of the judicial arena. However, as a species of civic

${ }^{89}$ E.g. Piyel Haldar, "In and Out of Court: Topographies of Law and the Architecture of Court Buildings (A Study of the Supreme Court of Israel)" International Journal for the Semiotics of Law Vol. VII, no. 20 (1994) 185200; and Rosemary Annable, A Setting for Justice: Building for the Supreme Court of New South W ales (Sydney: University of New South Wales Press, 2007).

${ }^{90}$ E.g. Anne Maass, et al., "Intimidating Buildings: Can Courthouse Architecture Affect Perceived Likelihood of Conviction?” Environmental Behavior 2000 32: 674 doi: 10.1177/00139160021972739

${ }^{91}$ E.g. NZHPT Register http://www.historic.org.nz

92 E.g. Resnik \& Curtis, "Representing Justice"; John N. Hazard, "Furniture Arrangement as a Symbol of Judicial Roles” ETC: A Review of General Semantics 19 (July 1962): 181-88.

${ }^{93}$ E.g. Martin, Built for Us; Richardson, "Building the Dominion".

${ }^{94}$ Linda Mulcahy, “Architects of Justice: the Politics of Courtroom Design” Social \& Legal Studies 2007 16: 383 , doi: 10.1177/0964663907079765. 
architecture, judicial architecture has significance beyond its walls and is therefore worthy of detailed investigation. Civic architecture may be defined as those buildings and spaces which serve as infrastructure for public life, including public parks and libraries, national and local government buildings, and indoor and outdoor public performance spaces. While research into judicial architecture seems to be limited, civic architecture (itself a subset of public architecture) has received more attention. Civic architecture, or civic spaces as Charles Goodsell calls them in his seminal work The Social Meaning of Civic Space, are "enclosures within governmental buildings designed for the performance of political rituals before audiences" $"$ which are "relatively accessible but not entirely unguarded"96 and are "built with the realisation that outsiders may be present on auspicious occasions." ${ }^{, 97}$ Civic spaces include national parliaments, city and regional council debating chambers, and town hall meeting rooms.

Goodsell's study of city council debating chambers provides useful background to this study as their performative function is clearly analogous to that of judicial architecture.

Courthouses are spaces built for the purposes of performing the rituals of justice, namely enquiry into grievances and the passing of judgment, and are prima facie open to the public at large in order that the community may be part of this ritual. ${ }^{98}$ It is judicial architecture's

\footnotetext{
${ }^{95}$ Charles T. Goodsell, The Social Meaning of Civic Space. Studying Political Authority Through Architecture (Lawrence: University Press of Kansas, 1988), xiv.

${ }^{96}$ Ibid., 11.

${ }^{97}$ Ibid.

${ }^{98}$ Resnik \& Curtis reinforce this description of justice as ritual in their investigation of the shift in the role of the public in the administration of justice from one of 'rite' to one of 'right'. See Judith Resnik \& Dennis E. Curtis, "From 'Rites' to 'Rights' of Audience. The Utilities and Contingencies of the Public's Role in CourtBased Processes” in Antoine Masson \& Kevin O’Connor, eds., Representations of Justice (Brussels: P.I.E. Peter Lang, 2007) 195-236.
} 
fundamental role of enabling and supporting the public aspects of the justice system that makes the investigation and understanding of the courthouse typology so important.

Goodsell's study involved analyses of American city council debating chambers dating from 1865 to the mid-1980s. Goodsell visited the subject sites, analysing them against the design features noted above, then drew conclusions about the ways in which democratic political culture was expressed in the architecture of the spaces. This resulted in the studied chambers being grouped into three generalised sub-typologies (Traditional (1865-1920), MidCentury (1920-1960), and Contemporary (1960-1980s)), each displaying variation in the architectural design features he analysed, thus inferring different conclusions regarding the democratic political culture of the era during which the chambers were designed and built. Much of Goodsell's study is illuminating to an investigation of judicial architecture. A successor to the pioneering work of Murray Edelman on political symbolism, ${ }^{99}$ Goodsell believes that all civic architecture contains an expression of political ideas, "a nonverbal statement emanating from the political culture of the time" ${ }^{\text {"100 }}$ :

[C]ivic space can be thought of as a kind of stage, with scenery and props designed and selected to convey a certain impression. By studying that stage, we can in effect study those who designed it and those for whom it was designed. ${ }^{101}$

Goodsell's assumption is that design features of civic architecture (such as social and architectural setting, composition of space, arrangement of furniture and allied features,

\footnotetext{
${ }_{99}$ Murray Edelman, The Symbolic Uses of Politics (Urbana: University of Illinois Press, 1964).

${ }^{100}$ Goodsell, Civic Space, xiv

101 Ibid., 11
} 
interior decoration, and overall aura of the space) express distinctive and meaningful concepts of political authority: ${ }^{102}$

[Civic spaces] are not randomly or casually brought into existence; they reflect various antecedents and predispositions, including architectural conventions of the day, the conscious preferences of those in power at the time, underlying characteristics of the prevailing system of political authority, and perhaps - certain universal human tendencies regarding spatial relationships. Thus, such space and the objects within it become what might be thought of as nonverbal commentary about people, politics, culture, and civilisation. ${ }^{103}$

One must bear in mind Goodsell's note of caution about approaching civic architecture with the intention of unpacking its expressive meaning:

Buildings, rooms, and objects are constructed of durable materials; hence they last a long time. We can use them as vivid and embracing portrayals of the past; walking into old spaces is, perhaps, the closest we can come to entering a time machine. At the same time, the expressive meaning of an architectural past must be interpreted with care, since it cannot be understood except by appreciating the sociocultural context in which it was built. ${ }^{104}$

That said, the very nature of civic spaces as sites of public political ritual means that convincing inferences as to the political values of the day can be made by attending to the detail of the architecture. As Goodsell recognises:

\footnotetext{
102 Ibid., xvi

${ }^{103}$ Ibid., 8.

104 Ibid., 8.
} 
Location, design, and layout [of civic space] have received the state's imprimatur. Ideas of authority and status, as reflected in the space, are either officially endorsed or at least are not in conflict with accepted regime values. ${ }^{105}$

It must also be noted that Goodsell's method did not involve any analysis of designers' goals or intentions in relation to civic architecture. It is suggested that the present study differs from Goodsell's in that the various stakeholders involved in the briefing and design of the Supreme Court complex expressed clear and discoverable intentions on the record and in interviews with the researcher, which, when understood in conjunction with the express judicial aspirations of the Supreme Court as an institution and the built form of the Supreme Court complex, permit an understanding of the complex's contemporary expressive meaning that Goodsell's work necessarily implied rather than discovered.

Another valuable study of judicial architecture in a jurisdiction similar to New Zealand is that undertaken in the late 1990s by the Law Reform Commission of Western Australia (LRCWA) as part of its review of the justice system in Western Australia. The review resulted in a comprehensive two-volume consultation document and then a final report, ${ }^{106}$ which were significant in that they interrogated the court environment as an important constituent element of the justice system, not just as something incidental to it. The opening sentences of the consultation document also shows why the LRCWA thought the understanding of judicial architecture so important in the context of its justice system review:

\footnotetext{
105 Ibid., 10.

${ }^{106}$ Law Reform Commission of Western Australia, Review of the Criminal and Civil Justice System in Western Australia Project 92 - Consultation Papers (June 1999) and Final Report (September 1999) (Perth: Government Printer, 1999) http://www.lrc.justice.wa.gov.au/092g.html
} 
Court buildings can be understood as living systems or cultural environments in which decisions are made about people's lives, property and rights. A court is not just a set of rooms, corridors and entrances; it is a social and emotional world. ${ }^{107}$

Chapter 34 of the final report (“The Court Environment") reiterated that view:

The physical and social environment of the courts and its impact on how citizens experience court processes may be an essential component in improving the justice system. This is because the design and aesthetics of court buildings may affect users' perceptions of the justice system. ${ }^{108}$

Implicitly accepting that judicial architecture performed similarly to civic architecture, the LRCWA noted Goodsell's study was valuable in the way it linked the design of civic spaces to changing political views about the relationship between citizens and the state and thus highlighted a questioning of whose views shape or should shape court buildings. ${ }^{109}$ Considering the work of the French judge and sociologist Antoine Garapon, the LRCWA cited Garapon's argument that careful attention must be paid to court symbolism, appearances and design to ensure that justice is executed in an orderly and accountable way:

\footnotetext{
[Garapon] argues that today's legal decisions are given credibility by legitimate authority inherited from the past. This raises the question of 'communication'. What do particular aspects of court buildings, or the rituals that take place therein, 'say' about justice, access, truth, or authority? Whereas the onward march of progress towards democracy and citizen participation can be traced in the design of council chambers, courts tend to be relatively conservative. ${ }^{110}$
}

\footnotetext{
${ }^{107}$ LRCWA, Consultation Papers, 1017.

${ }^{108}$ LRCWA, Final Report, 301.

${ }^{109}$ LRCWA, Consultation Papers, 1020.

110 LRCWA, Consultation Papers, 1021. See Antoine Garapon, Bien juger: Essai sur le rituel judiciaire (Paris: Editions Odile Jacob, 1997).
} 
As noted above, the LRCWA study recognised the role that judicial architecture plays in communicating to court users the values of those who administer the justice system and the values placed on the users as participants in that system. Writing on ritual and ceremony in relation to civic architecture, Goodsell notes that the experience of participants is:

imparted to a substantial degree by elaborate staging, since what is communicated is more presentational than discursive. Embodied in the staging are, not objective facts, but our deepest understandings of the world and the underlying values with which we engage it. ${ }^{111}$

For Goodsell, this architectural staging supports the ceremonial and ritualistic behaviours associated with civic (and, it is suggested, judicial) space. In turn, ritualism is supported by the manipulation of symbols:

Ceremonial ritual achieves its power over the human mind and spirit through the manipulation of symbols. [...] By the careful manipulation of symbols, vaguely articulated but deeply felt beliefs can be mobilized at a given time and place. Because of its dedication to ritual, civic space is, not surprisingly, replete with symbols; in fact, the space as a whole can behave symbolically. ${ }^{112}$

Goodsell employs Peter F. Smith's definition of a symbol, which (unlike the sign and the icon) suggests only vaguely and indirectly that for which they stand. ${ }^{113}$ Goodsell notes that "[t] he very inarticulateness of symbols makes us interpret, not understand, their meaning": ${ }^{114}$

111 Goodsell, Civic Space, 25.

112 Ibid., 12.

113 Ibid, 25.

114 Ibid., 26. See also LRCWA, Consultation Papers, 1021, where the Commission discusses art historian Katherine Taylor's work which notes sometimes conflicting symbols in French courtrooms in the Second Empire denoting authority to judge coming from God, the monarch, and/or the people. See Katherine Taylor, In the Theatre of Criminal Justice (Princeton, NJ: Princeton University Press, 1993). 
"Reduced to its simplest, a symbol is a phenomenon (object, sound, smell or tactile sensation) which has a meaning additional to that which is communicated by its superficial configuration or stimulus profile. It stands for a 'landscape' of meaning without a precise horizon. Because of the contrast between the relative simplicity of the object and the potential complexity of the meaning towards which it points, the experience of symbols evokes an emotional reaction. [...] Most of these reactions remain out of reach of consciousness, but can nevertheless have a decisive influence upon mood and behaviour."115

It is important in this context also to note the seminal work of Murray Edelman on the relationship between symbolism and politics, The Symbolic Uses of Politics, which found that in general terms the physical characteristics of political stages invariably include massiveness, ornateness, and formality:

The degree to which the physical setting is emphasized in political performances depends on (1) the importance of impressing large audiences, (2) the need for legitimizing acts and for securing compliance, and (3) the need to establish or reinforce an official's definition of self.116

This is certainly true in relation to judicial architecture, which at a superficial level is simply a venue for court proceedings, but which at a deeper level is an expression of a political demand: that architecture shall make edifices befitting the importance and power of these institutions, that it shall make these institutions appear mighty and durable, and that is shall, in its symbolism and expressive form, state dramatically something of these institutions' 'idea' of the world. ${ }^{117}$

\footnotetext{
115 Peter F. Smith, “Architecture, Symbolism and Surrealism,” Architectural Design 48 (2) (1978): 150 quoted in Goodsell, Civic Space, ch. 2, n. 3.

${ }^{116}$ Edelman, The Symbolic Uses of Politics, 95-99, quoted in Goodsell, Civic Space, 28.

117 David Milne, “Architecture, Politics and the Public Realm” Canadian Journal of Political and Social Theory 5 (Winter/Spring 1981): 131-146, quoted in Goodsell, Civic Space, 29.
} 
Two further points regarding architectural symbolism bear mentioning in the present context. The first is Rudolf Arnheim's view that architectural symbolism is not merely a subjective phenomenon, but rather is an innate given in a building's architectural dynamics. For example, a staircase as geometric form expresses nothing until conceived of as a dynamic crescendo from ground to upper level, while a building lacking windows inherently conveys a quality of closedness or tightness of mind. ${ }^{118}$ The second is Joseph R. Gusfield's concept of “symbolic gestures.” To Gusfield, “'cohesive' symbolic gestures embrace, in a unifying way, all persons who are present, whereas 'differentiating' symbolic gestures divide people according to status or subgroup." 119 Examples of unifying symbols noted by Goodsell are flags and emblems that represent a whole community whereas differentiating symbols would include thrones for royalty while requiring commoners to sit in ordinary chairs. ${ }^{120}$

Returning to the LRCWA report, the Commission ultimately concluded that the shape and content of judicial architecture is of fundamental importance in the delivery of justice in the community:

Court buildings convey information about the justice system. Good court design may communicate that justice is accessible; safety and privacy are respected; and contributions to the process are welcomed. All too frequently, however, architecture may send out other messages:

- $\quad$ the courts are isolated from our physical and cultural environment;

- $\quad$ the courts are closely linked to other law enforcement agencies;

\footnotetext{
118 Rudolf Arnheim, The Dynamics of Architectural Form. Berkeley: University of California Press, 1977, pp. 210, 253-54, cited in Goodsell, Civic Space, 35.

${ }^{119}$ Joseph R. Gusfield, Symbolic Crusade: Status Politics and the American Temperance Movement, Urbana: University of Illinois Press, 1966, cited in Goodsell, Civic Space, 37.

${ }^{120}$ Goodsell, Civic Space, 37.
} 
- $\quad$ all people are not equals in the court;

- $\quad$ jury service is not valued;

- participants and the public are not entitled to understand the proceedings; and

- court management needs are more important than the time commitments of civilian participants in the justice system. ${ }^{121}$

In the LRCWA's view, "the characteristics of courthouse spaces tacitly inform the users of their status before the law:"

\begin{abstract}
Some courthouses inform citizens they have the same rights as others. Others inform citizens they must defer to their 'betters'. Still other design aspects and behaviours signal that an accused is 'criminal'. Court facilities and staff signal to parties and victims whether or not their claims are being taken seriously. Although users may not be conscious of 'reading' the environment in these terms, they may feel more of less comfortable in different court spaces and by the way they are treated by court staff and legal professionals. ${ }^{122}$
\end{abstract}

It was for that reason that the LRCWA recommended (inter alia) that care be taken in designing courthouses concerning the values expressed and the means of representing the justice system through architectural design, the user-friendliness of facilities, and having spaces that encourage the treatment of all participants in the justice system with courtesy, respect and fairness.

\footnotetext{
${ }^{121}$ LRCWA, Final Report, 304.

${ }^{122}$ LRCWA, Consultation Papers, 1027.
} 


\section{Summary}

The theoretical perspectives described in Chapter III show that, like civic architecture, judicial architecture communicates the contemporary judicial aspirations of those who create it. It does so through the careful and mindful manipulation of architectural symbols in a process Goodsell and others understand as "stage setting." The role of the courthouse in this communication of aspirations for the judicial system is self-evident; courthouses are by definition the stages for the public ritual of justice and are replete with political symbols relating to how such justice is (or should be) administered. Judicial architecture's fundamental role of enabling and supporting the public aspects of the justice system makes the studying the courthouse typology so important. Drawing on these perspectives, the underlying assumption of this study is that the New Zealand Supreme Court complex embodies judicial aspirations for the justice system, those embodied aspirations having expressly or implicitly received the state's imprimatur through the briefing process. 
IV.

\section{Briefing the Supreme Court Project}

The review of theory and history undertaken in Chapter III of this thesis provides this study with an understanding of how and why judicial architecture expresses judicial aspirations. The aim of Chapter IV is to assess the judicial aspirations of the Supreme Court as these are evinced through two sources: 1) the drafting of the purpose section (section 3) of the SCA; and 2) the translation of the aspirations expressed in the legislation into requirements within the Supreme Court complex's briefing documents. This analysis engages with the Supreme Court legislation from introduction to enactment, revealing the aspirations for the New Zealand judicial system that were intended with the establishment of the Supreme Court, and the various premises briefs promulgated by the project's steering group (as informed through consultation with the project's judicial and political advisors) insofar as these were made available to the researcher.

\section{The Judicial Aspirations of the Supreme Court}

From the late 1990s the New Zealand Parliament has included purpose sections in legislation in order to guide interpreters of the law to understand its intentions in enacting those statutes. The purpose of the Supreme Court is found in section 3 of the SCA. The development of section 3 of the Act is important in the context of this study since it is suggested that the aspirations for the New Zealand judicial system intended by Parliament and the promoters of the Court are to be found there. This section analyses the development of section 3 (and the related section 13) in detail. The precise wording of the 
prototypical section 3 (clause 3 of the Supreme Court Bill) as introduced to Parliament stated:

\section{Clause $3 \quad$ Purpose}

The purpose of this Act is to -

(a) establish the Supreme Court of New Zealand as the court of final appeal for New Zealand, and provide for its jurisdiction and related matters; and

(b) end appeals to the Judicial Committee of the Privy Council from decisions of New Zealand courts; and

(c) make related amendments to certain enactments relating to courts or judicial proceedings.

An allied provision, clause 13 of the Bill (the leave to appeal criteria provision), stated:

\section{Clause 13 Criteria for leave to appeal}

(1) The Supreme Court must not give leave to appeal to it unless it is satisfied that -

(a) the proposed appeal involves a significant issue relating to the Treaty of Waitangi or tikanga Maori; or

(b) the proposed appeal involves some other matter of general or public importance; or

(c) a substantial miscarriage of justice may have occurred, or may occur unless leave is given; or

(d) the proposed appeal involves a matter of general commercial significance; or

(e) it is necessary in the interests of justice for the Court to hear and determine the proposed appeal.

(2) $[\ldots]$

Two important points should be noted from clauses 3 and 13. First, clause 3 expresses what are best understood as purposes of the Act, essentially to establish the Supreme Court. 
Second, the priority given to issues involving the Treaty of Waitangi and tikanga Maori ${ }^{123}$ in clause 13 is significant. The Explanatory Note to the Bill implicitly justified this prioritisation by describing the Treaty as "New Zealand's founding document," 124 reinforcing the view of the constitutional role of the Treaty described in Chapter II of this study.

The Justice and Electoral Select Committee received submissions on the Supreme Court Bill and reported back to Parliament on 16 September 2003, recommending a number of significant changes to the wording of clauses 3 and 13. In relation to the purpose clause, the Select Committee recommended that clause 3 be:

amended to reflect the broader context of the Bill, which includes New Zealand's commitment to the rule of law and the sovereignty of Parliament. The exact wording of this amendment was the subject of considerable debate amongst members, and it now emphasises the independence of New Zealand and the importance of the Treaty of Waitangi. ${ }^{125}$

$[\cdots]$

Most of us support the reference in the amended purpose clause to the Treaty of Waitangi. These members recognise that the Treaty of Waitangi is part of New Zealand's jurisprudence, and consider the new purpose clause goes some of the way to meeting concerns [of submitters] at the lack of recognition accorded to the Treaty in the Bill. ${ }^{126}$

\footnotetext{
${ }^{123}$ Tikanga $\mathrm{M}$ ori is understood in this context as $\mathrm{M}$ ori customary values and practices.

124 Supreme Court Bill 2002 (16-1), Explanatory Note, p 3.

125 Supreme Court Bill 2002 (16-2), Commentary, p 22.

${ }^{126}$ Supreme Court Bill 2002 (16-2), Commentary, p 24.
} 
Faced with concern from some submitters that a Supreme Court might see fit to challenge Parliament's law-making monopoly, clarifying the relationship of the Supreme Court within the doctrine of the separation of powers was also an object of the Committee's amendments:

National and ACT members argue that the purpose clause should restrain judicial activism. [...] We consider the proposed amendment [subsection 3(2)] effectively restates the primacy of Parliament in making law and determining public policy issues. ${ }^{127}$

This is significant. While the Bill originally did not provide for them, these two aspects, the role of the Treaty of Waitangi and the role of the Supreme Court in upholding the rule of law and Parliamentary sovereignty, were evidently quintessential for the Select Committee when considering the purposes of the Supreme Court. Parliament agreed with the Select Committee; the Committee's recommended wording of clause 3 was enacted and will be considered further below.

The original inclusion in clause 13 of the Bill of reference to "tikanga M ori" was also amended by the Committee:

Clause 13 sets out the criteria for leave to appeal to the Supreme Court. A majority of the 28 submissions on this clause were critical of its prescriptive approach and recommended wider criteria. We recommend the reference to tikanga $\mathrm{M}$ ori in clause 13 be removed. The Attorney-General informed us that the tikanga $\mathrm{M}$ ori leave provision was drafted in response to consultation with $\mathrm{M}$ ori, and that in each case the tikanga will be determined before it comes to the Supreme Court. However, we agree with those submitters who raised concerns that 'a significant issue relating to tikanga M ori' was too broad a matter for inclusion in the leave criteria. [...] The issue of 'tikanga M ori' was raised by several submitters. Most favoured deleting the reference from the leave criteria,

127 Supreme Court Bill 2002 (16-2), Commentary, $22 \mathrm{f}$. 
either because the leave criteria should be set out in general terms or because the reference is

discriminatory. ${ }^{128}$

The priority given to Treaty and tikanga $\mathrm{M}$ ori issues noted above also concerned the Select Committee, which recommended "further amendments to clause 13, to clarify that the leave criteria are not hierarchical." ${ }^{, 129}$ As with clause 3, the amended wording of clause 13 was adopted by Parliament and, together with the rest of the amended Bill, became law when the Supreme Court Act received Royal Assent from the Governor-General on 17 October 2003. The Act came into force on 1 July $2004 .^{130}$

The enacted wording of section 3 reads:

3 Purpose

(3) The purpose of this Act is-

(a) to establish within New Zealand a new court of final appeal comprising New Zealand judges-

(i) to recognise that New Zealand is an independent nation with its own history and traditions; and

(ii) to enable important legal matters, including legal matters relating to the Treaty of Waitangi, to be resolved with an understanding of New Zealand conditions, history, and traditions; and

(iii) to improve access to justice; and

(b) to provide for the court's jurisdiction and related matters; and

(c) to end appeals to the Judicial Committee of the Privy Council from decisions of New Zealand courts; and

(d) to make related amendments to certain enactments relating to courts or judicial proceedings.

\footnotetext{
128 Supreme Court Bill 2002 (16-2), Commentary, 44.

129 Supreme Court Bill 2002 (16-2), Commentary, 44.

${ }^{130}$ See Appendix I - Supreme Court legislation (excerpts).
} 
(4) Nothing in this Act affects New Zealand's continuing commitment to the rule of law and the sovereignty of Parliament.

In strict legal terms, section 3 expresses the purpose of the SCA rather than the Supreme Court itself. However, section 3 inherently expresses a mix of the purposes of the legislation and the purposes of the institution. For example, providing for the Supreme Court's jurisdiction and ending appeals to the Privy Council are purposes of the legislation. The purposes of the institution, on the other hand, are:

a) To recognise New Zealand as an independent nation with its own history and traditions (section 3(1)(a)(i));

b) To enable important legal matters, including those relating to the Treaty of Waitangi, to be resolved with an understanding of New Zealand conditions, history and traditions (section 3(1)(a)(ii));

c) To improve access to justice (section 3(1)(a)(iii)); and

d) To continue New Zealand's commitment to the rule of law and sovereignty of Parliament (section 3(2)).

It is suggested that these institutional purposes are significant in that they express the judicial aspirations of the Supreme Court. As stated in Chapter I, the aim of this study is to assess the design of the Supreme Court complex as the embodiment of judicial aspirations, that embodiment being a legible response to the complex's briefing process which expresses the judicial aspirations of the New Zealand justice system at the beginning of the $21^{\text {st }}$ century as enshrined in section 3 of the SCA. Drawing on the above analysis of section 3 , the three aspirations against which the Supreme Court architecture will be assessed are: 
1. the independence of New Zealand's justice system within the context of its history and traditions (purpose a) above);

2. the social context of the New Zealand justice system (in particular the relevance of the Treaty of Waitangi) (purpose b) above); and

3. commitment to upholding the rule of law (including access to justice) and the sovereignty of Parliament (purposes c) and d) above).

\section{The Supreme Court Brief}

When it first sat in July 2004, the Supreme Court did so in a basement-level room in the Wellington High Court building, with the court registry and judges' chambers located nearby within the Victoria University of Wellington Law Faculty in the former Government House building. In early 2006 officials at the Ministry of Justice (MoJ) began to develop a brief for stand-alone premises for the Court, initially directing the restoration of OHCB to serve that purpose as had been recommended by the MAG in $2002 .{ }^{131}$ To the consternation of many architects and commentators there was neither an open nor an invited competition for the design of this significant civic building. ${ }^{132}$ WaM's lead architect for the Supreme Court project, Roy Wilson, explained that the MoJ officials leading the project did not wish to have a design competition for the Supreme Court project because they were looking for a team to deliver the project in a collaborative, iterative manner, working through a process that developed the design in response to the aspirations of the stakeholders, rather than a design outcome developed in isolation through competition which would then require compromise

\footnotetext{
131 Attorney-General, Replacing the Privy Council, para 167.

132 See Roy Wilson et al. “Natural Justice” Architecture NZ 2:2010 (March/April): 50-60, 60.
} 
on the parts of stakeholders and designers to make work. ${ }^{133}$ Responding to an open MoJ request in 2004, WaM had previously submitted a memorandum outlining their capacity to provide design services for courthouses, on the basis of which the Ministry invited WaM to tender for the Supreme Court project. ${ }^{134}$ One could expect that WaM's lengthy pedigree in designing key civic and public buildings (including the Christchurch Town Hall (1972), the Waiouru Army Museum (1977 and 1984), the New Zealand Chancery in Washington, D.C. (1979), the New Zealand High Commission in New Delhi (1991), and, most recently, the Parliament and Executive Wing (Beehive) buildings refurbishments (1996 and 2003 respectively) also had something to do with their appointment. ${ }^{135}$ Ultimately, the team assembled to develop the Supreme Court design was known as the Project Steering Group (PSG) and comprised representatives from the MoJ, members of the Supreme Court judiciary and registry staff, WaM, and project managers The Building Intelligence Group. Through consultation with Ministers, government agencies and the judiciary, the PSG developed a series of design brief iterations for the Supreme Court which outlined three key parameters: 1) physical parameters; 2) functional parameters, and 3) time and cost parameters. ${ }^{136}$ The question of how the building should look was largely given over to the architects however.

\footnotetext{
${ }^{133}$ Roy Wilson (Principal, Warren and Mahoney), in discussion with the author, March 2011.

134 Wilson, discussion; Andrew Hampton/Joanne Jeppesen (Ministry of Justice), in discussion with the author, July 2011.
135 The Executive Wing Refurbishment project was still under construction when the MoJ invited WaM to tender on the Supreme Court project. MoJ officials indicated that a number of other architectural practices were also invited to tender for the project, which practices is not known however. Hampton/Jeppesen, discussion.

136 Project Steering Group, "Supreme Court Permanent Premises Project. Option C (Modified) Parameters" (6 April 2006). See Appendix 2 - Supreme Court - Design Briefs.
} 
A Cabinet Paper from the then Minister for Courts shows that the briefing process undertaken reflected the collaborative approach desired by the MoJ for delivery of the Supreme Court project in that there was extensive consultation regarding the project by MoJ officials with the Minister for Courts, the NZHPT, the Ministry for the Environment, and the judiciary, each layer influencing the framing of the brief. ${ }^{137}$ For example, consultation with the NZHPT and the Ministry for Culture and Heritage over the concept designs for the Supreme Court revealed objections to original proposals predicated on substantial modification of the OHCB to make it appropriate for Supreme Court purposes. In response to such opposition the Cabinet paper referred to above outlined four alternative options for the development of permanent accommodation for the Supreme Court. Option A proposed use of the OHCB for the Supreme Court, with a degree of demolition of that building to make it suitable for the new Court. Option B proposed a separate Supreme Court with linkages to a restored $\mathrm{OHCB}$ but with no demolition of the latter. Option C proposed partial demolition of the OHCB with a large new addition linked to it in which the Supreme Court would be housed, with use of the OHCB by the Supreme Court. Option D proposed a stand-alone Supreme Court building with no linkage to or use of a restored OHCB by the Supreme Court. The Cabinet paper shows that the judiciary were opposed to any operational restrictions that would result from being located within the existing fabric of the OHCB. This included not having a bench large enough to accommodate the five sitting judges comfortably, limitations on the space available for the public and media, concerns about not co-locating clerks with the judges they serve, then need for extensive library facilities, and a concern that the compromise required in making use of Courtroom 1 of the

\footnotetext{
137 Office of the Minister for Courts, "Memorandum for Cabinet Policy Committee" (undated, c. March 2006). See Appendix II - Supreme Court - Design Briefs.
} 
OHCB would necessitate establishment of a new, larger court in the future. The NZHPT objected in principle to any option that included demolition of any significant part of the OHCB, but proposed a fifth option known as Option C (Modified). ${ }^{138}$ Under that option demolition of the 1981 extension at the rear of the OHCB to enable connection with a new Supreme Court building would be acceptable, with the rest of the OHCB being restored and made available for other MoJ or ceremonial purposes.

Cabinet ultimately approved Option C (Modified) and the project brief was refocused to deliver a new Supreme Court building together with the complete restoration of the OHCB, essentially creating two projects from what had originally been conceived as one. ${ }^{139}$ Three explicit directions were given to the architects under the final iteration of the premises brief:

1. the new Supreme Court building was to be located on the original site of the Armed Constabulary and Court of Arbitration buildings (at the time of briefing known as Justice Park), with public entry to the building from Lambton Quay;

2. the OHCB was to be modified by removal of the 1981,1913 and part of the 1907 additions, and fully restored to provide for better efficiency, functional improvements, and achieve a 100 year design life; and

3. the new Supreme Court building exterior should reflect the status of the Supreme Court as the repository of NZ law and the apex of the third arm of Government. The building should not be ostentatious but was to be of substance and of enduring

\footnotetext{
138 Ibid.

${ }^{139}$ Hampton/Jeppesen, discussion. See also Project Steering Group, “Option C (Modified) Parameters”.
} 
design. It was to be respectful to the $\mathrm{OHCB}$ and not dominate it in relation to height. $^{140}$

The Supreme Court judges also provided WaM with three key parameters. First, it was taken for granted by the judiciary and the $\mathrm{MoJ}$ that the Court should function correctly. ${ }^{141}$ Further, the judges asked that they be able to see to the exterior from the courtroom, to the daylight, sky, and activities of the world outside. Finally, the judges expressed a desire that the building be representative of all New Zealanders as a nation, a building that "didn't pay too much more recognition to any one cultural background than others." ${ }^{142}$ MoJ officials described the substantial debate at the briefing stage of the Court's design over what sort of "cultural identity" the building should have, whether it should have a substantial Maori cultural content or whether to bring in references to other cultures in New Zealand. The decision was made to instead incorporate something that was "of New Zealand," namely the references to native flora. ${ }^{143}$ According to Roy Wilson, the wishes expressed by the judiciary strongly influenced the design of the courthouse throughout, from spatial planning promoting collegiality and a discussion-enabling courtroom to furniture style and art works. ${ }^{144}$ It should be noted, however, that approval of the design of the Supreme Court

\footnotetext{
140 Project Steering Group, "Supreme Court. Premises Brief Version 4” (28 March 2007) 1. See Appendix II Supreme Court - Design Briefs.

141 Wilson, discussion.

142 Wilson, discussion.

${ }^{143}$ Hampton/Jeppesen, discussion. See further discussion on this point in Chapter VI - "An Indigenous Court."

144 Ibid.
} 
complex was a Cabinet decision; while the judiciary were consulted extensively and had significant input into the design, final approval was made at ministerial level. ${ }^{145}$

While there is no direct evidence that the provisions of the SCA informed the Supreme Court project brief, it is suggested that point 3 (above) and the requirements of the judiciary relate directly to the judicial aspirations of the Supreme Court as extrapolated from the legislation in the previous section. A notable exception, however, is the desire for "cultural neutrality" for the Supreme Court building. This aspect of the complex's brief and design seems notably at odds with the judicial aspirations contained in the legislation; this matter will be explored further in Chapter VI.

\section{Summary}

Chapter IV illustrates the layered briefing process undertaking with respect to the Supreme Court complex, showing how the Court's constituting legislation expressed the judicial aspirations of the institution and revealing how these aspirations were translated into requirements within the Supreme Court complex's briefing documents. The aspirations for the New Zealand judicial system contained in the Supreme Court Act are suggested to be:

a) To recognise New Zealand as an independent nation with its own history and traditions;

b) To enable important legal matters, including those relating to the Treaty of Waitangi, to be resolved with an understanding of New Zealand conditions, history and;

c) To improve access to justice; and

${ }^{145}$ Hampton/Jeppesen, discussion. 
d) To continue New Zealand's commitment to the rule of law and sovereignty of Parliament.

The various premises briefs devised by the PSG illustrate the layered process this briefing took, with the brief being regularly revised and updated in accordance with consultation with the project's judicial and political advisors from the Supreme Court bench, the NZHPT and Ministries of Justice, Culture and Heritage, and the Environment. While the outcomes of some of this consultation were made available to the researcher, some influences on the briefing process remain unknown. For example, it is unclear the extent to which informal directions may have been given to the architects by stakeholders in relation to design of the Court. What is known about the consultation during the briefing process is that it influenced the splitting of the project into two components (the restoration of the OHCB and design of a new Supreme Court building) ${ }^{146}$ and that the judiciary had an important role in the briefing of the project, requiring that the courtroom be exemplary in terms of planning, environmental, and acoustic performance, that it embody a sense of openness and collegiality, and that the courthouse exhibit a neutrality through avoiding what has been termed "cultural ownership" of the building.

While there is no direct evidence that the provisions of the SCA informed the Supreme Court project brief, it is suggested that the brief's requirements, read together with the requirements of the judiciary, relate directly to the judicial aspirations of the Supreme Court

\footnotetext{
146 A true split never occurred as both aspects continued to be undertaken under the rubric of one project. MoJ officials considered this approach may have contributed to political and public criticism regarding budget overruns as the original budget for the "project" was extended considerably to cover the restoration of the OHCB. The Supreme Court building was, however, delivered within its original budget. Hampton/Jeppesen, discussion.
} 
as expressed in the legislation. Chapter V of this thesis, The Architecture of the Supreme Court Complex, analyses the outcome of this briefing process, the Supreme Court's built form. 


\section{The Architecture of the Supreme Court Complex}

With the understanding developed in Chapter IV of the Supreme Court project's layered briefing process, Chapter V of this thesis analyses the architecture of the Supreme Court complex in order to provide a detailed understanding of the Court's built form and the multiple considerations and influences that went into its design from an architectural perspective. This case study draws heavily on interviews and architectural drawings and images provided by the complex's architects and the OHCB conservation work undertaken by heritage architect Chris Cochran, as well as archival research on the design of the complex and an in-context assessment of the buildings.

\section{The Supreme Court Building}

The Supreme Court complex is bounded by Lambton Quay and Ballance, Stout and Whitmore Streets (Ill. 34 \& 35). The Lambton Quay frontage was the site of the former Justice Park; ${ }^{147}$ the Stout Street frontage that of the OHCB. The appropriateness of this site for the new Supreme Court was never really in question. While other options were cursorily considered, the fact that the site was already owned by the MoJ, its location at the edge of central business district within

\footnotetext{
147 The site known as Justice Park was never officially reserved for public recreation purposes; it was the original site of the Armed Constabulary and Court of Arbitration buildings and always intended for eventual use by the Crown but had been improved with landscaping to enable its use by the public in the meantime. Hampton/Jeppesen, discussion.
} 


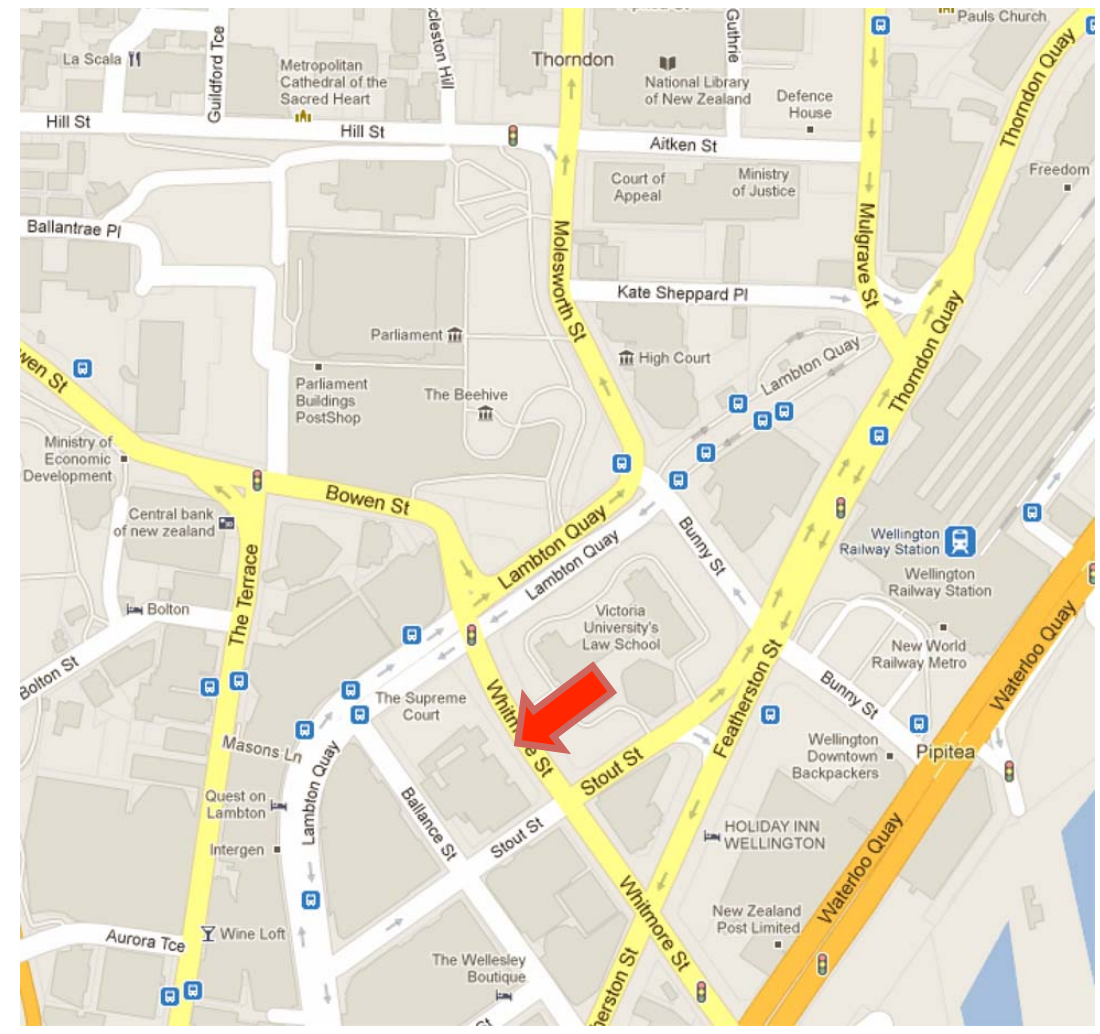

Ill. 34 The Supreme Court complex - locality

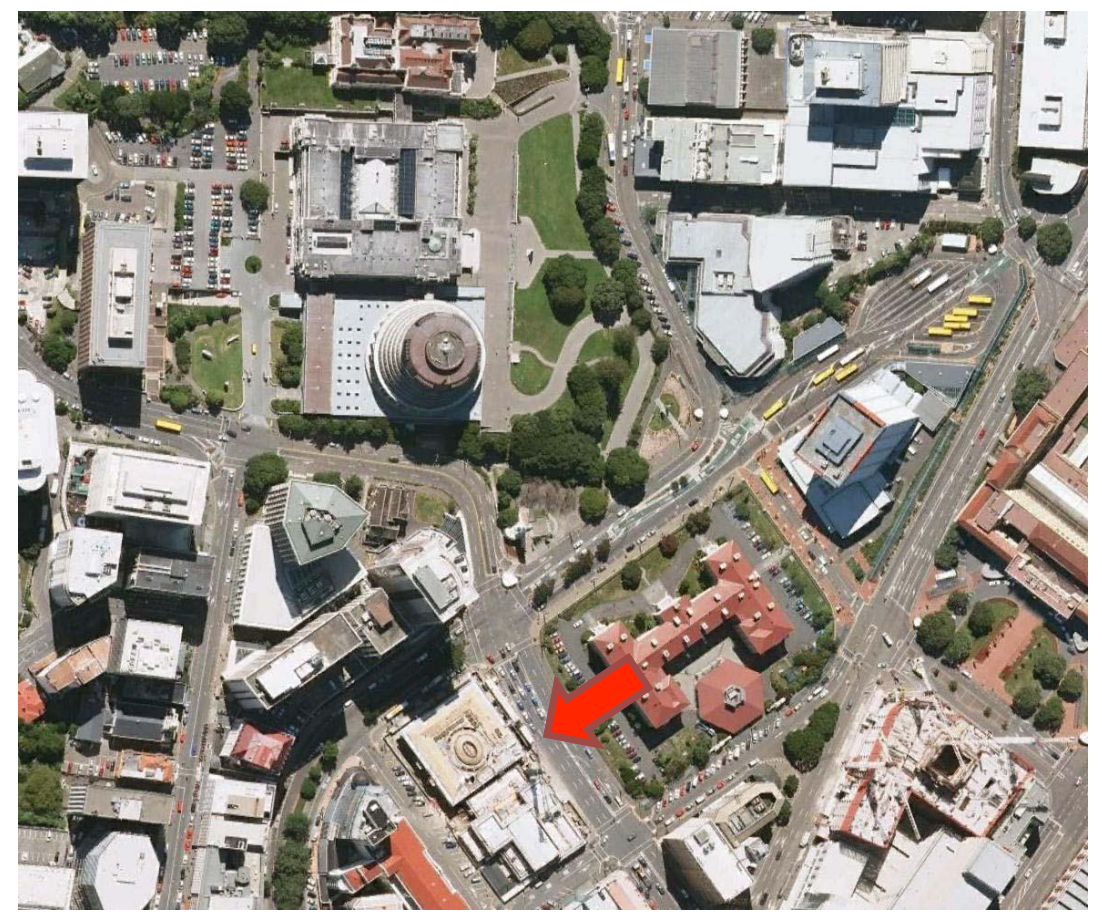

Ill. 35 The Supreme Court complex - aerial view 
the government quarter and at beginning of the Lambton Quay commercial area, and its significant cultural heritage value meant that other potential sites were quickly dismissed. ${ }^{148}$ The presence of the $\mathrm{OHCB}$ presented an interesting opportunity and challenge to the architects. As described above, the initial intention of the PSG (based on the recommendation of the MAG) was that the Supreme Court be housed within the existing OHCB. This intention quickly became untenable once it was realised that the OHCB could not provide the functionality required by the judges given the renovation and modification limitations imposed by the building's NZHTP and Wellington City District Plan heritage building listings. The brief (and budget) were therefore reframed in terms of the design and construction of a new Supreme Court building, while restoring and utilising the OHCB as an extra High Court courtroom and as ancillary space to support the functioning of the Supreme Court.

Looking at the Supreme Court complex from the direction of Parliament (Ill. 36), it is clear that this relatively demure building is one of reserved significance. As noted in Chapter IV, the final iteration of the brief given to WaM for the new Supreme Court building asked for a building of substance and of enduring design, sensitive to the OHCB, and reflective of the status of the Supreme Court as the repository of NZ law and the apex of the third arm of Government. The scale of the Supreme Court building is indeed sympathetic to the OHCB, and also to the former Government Building opposing it on Whitmore Street given the relationship of the OHCB to the Government Building described in Chapter II. ${ }^{149}$ The

\footnotetext{
${ }^{148}$ Hampton/Jeppesen interview; Wilson, discussion.

${ }^{149}$ See p 56 (supra). This sympathy is again the result of the consultative approach to the design of the Supreme Court undertaken. Roy Wilson described a process where the relationship of the new building with the old was workshopped with parties representing built heritage interests using large format elevation mock ups to arrive at an appropriate proportion of similarity and distinction between the buildings. Wilson, discussion.
} 
building forms an appropriate step in vertical scale from Whitmore Street and Lambton Quay to the taller buildings fronting Stout and Ballance Streets (Ill. 37). A much taller building (which would also have accommodated commercial floor space) was considered by the architects early in the design process, but was discounted in favour of something "small and special, rather than tall and commercial."150 Essentially a "regular modernist box" $" 151$ of concrete and glass, the recycled bronze $\mathrm{p}$ hutukawa/r $\mathrm{t}$ screen which wraps the building provides form, privacy, shelter and shading to the interior of the building and lends to it an iconic aspect, setting it apart from the ubiquity of concrete and glass buildings in the vicinity (Ill. 38). For the size of the building, the relative scale of the bronze screen denotes an important building, implying the enclosure and protection of something unique. Roy Wilson described the process of devising the screen thus:

\footnotetext{
We knew we were going to screen this glass box. The screen went through endless iterations about what we should do. We tested out a number of options and it became clear in that process of things that there is a relationship to the New Zealand landscape. If you are going to make a pattern on a building in a screen what do you do? You look out there and see those trees, those lovely branches, and you look through those and we said, well why isn't that the process of how we go and why don't we take it that way? So we started the development of the design of that image of looking through the branches and we said pohutukawa trees, and once you start the story is easy to build up, you know, pohutukawa and rata, North and South Island trees, converge in Wellington as one species, they represent New Zealand, longevity, power, mana, shelter, protection, enclosure - all of those things. And isn't that what the Court is all about? It's not about the state dominance over its citizens; it's all about our nature [...].
}

\footnotetext{
${ }^{150}$ Wilson et al., "Natural Justice", 52

${ }^{151}$ Ibid., 60
} 


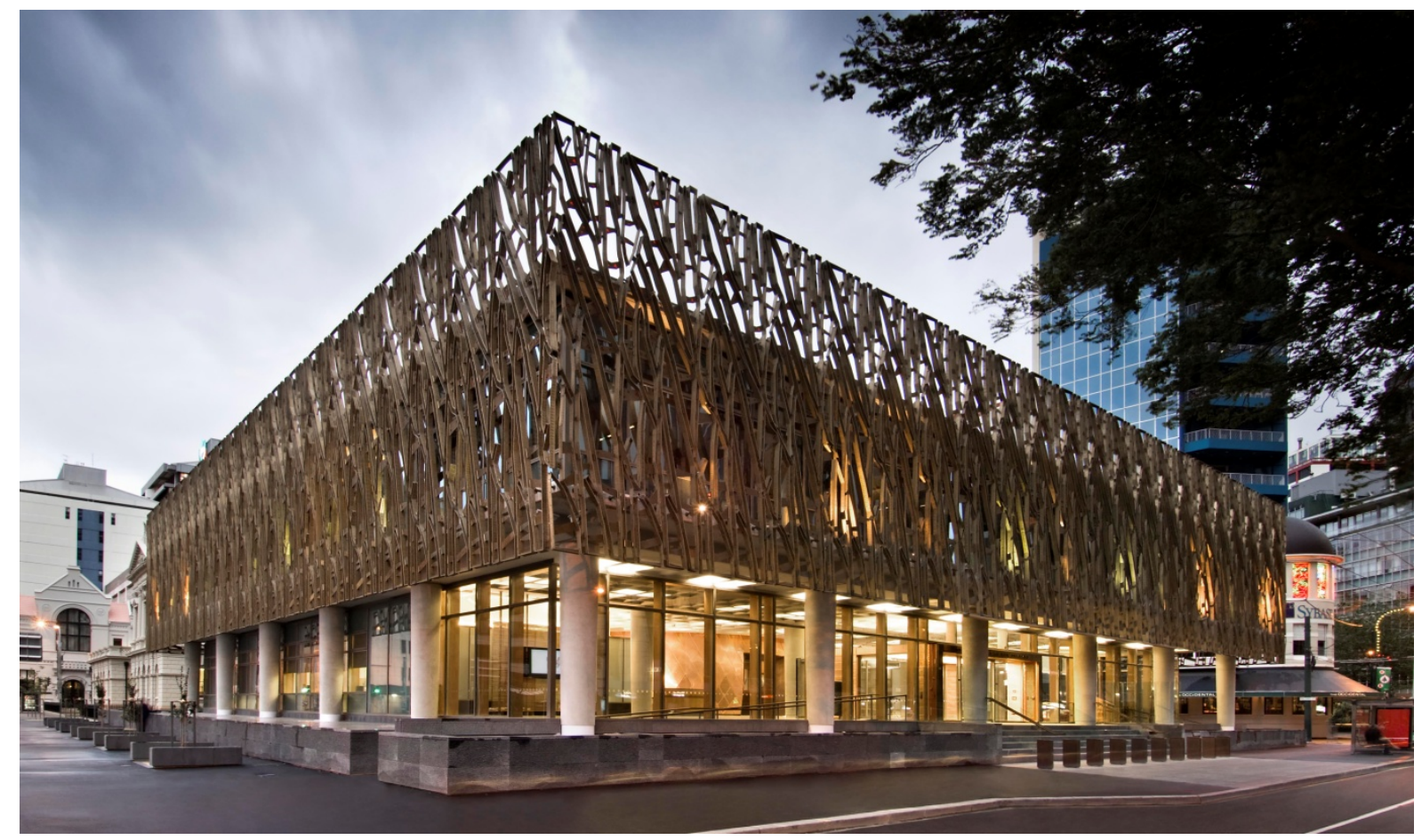

Ill. 36 Supreme Court viewed from intersection of Lambton Quay and Whitmore Street

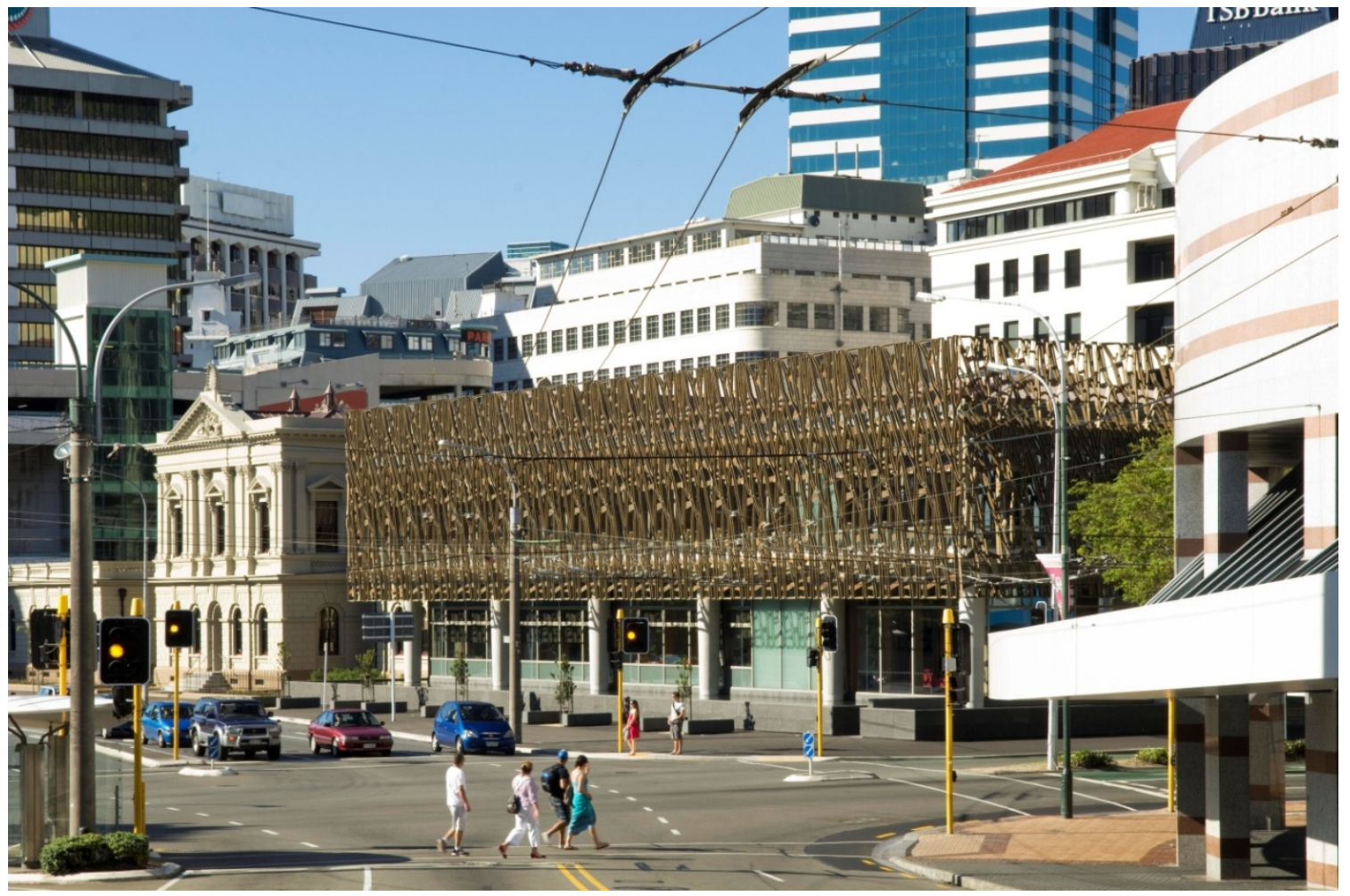

Ill. 37 Supreme Court complex with Stout and Ballance Street buildings beyond 
We carried on the development of the design and it became clear that we weren't going to build it out of plastic or steel or aluminium, it had to be bronze. When we presented the design and that story that went with it, it was tick tick tick tick, everybody just instantly said that's what we've got to do. We said that's where we've got to, we'd like to push it a bit further, it would be good if an artist had a look at this to cast an eye over it. We suggested Neil Dawson. ${ }^{152}$

It was Christchurch sculptor Neil Dawson who suggested the inclusion of red glass "blossoms" in the screen design (Ill. 39). On closer consideration, one notices the branch pattern (which comprises some 84 modules of 17 component parts each) has been designed with a greater density at the top and bottom and more open through the mid-range to maximise shading from above, privacy from below, and transparency for users through the mid-range. ${ }^{153}$ There is a legible rhythm and modulation to the screen pattern which has led one commentator to see a relationship between the screen and elements of the $\mathrm{OHCB}$ elevations. ${ }^{154}$

Approaching the Supreme Court one ponders the placement of the entrance to the Court square onto Lambton Quay (Ill. 40). While this access point was stipulated in the brief, ${ }^{155}$ mirroring and extending the strong axial symmetry of the $\mathrm{OHCB}$, urban designer Gerald Blunt has commented that this seems a missed opportunity:

The symmetrical planning of the old building has been carried through to the new building with the axis terminating at a bus stop on the adjacent side of Lambton Quay. What is so special about this

\footnotetext{
152 Wilson, discussion. It should be noted that the screen was developed by WaM's Christchurch office under the design leadership of WaM principal Bill Gregory.

${ }^{153}$ Wilson, discussion. See also Appendix IV - Supreme Court - Architectural Drawings.

154 Wilson, et al., "Natural Justice”, p. 52.

155 Project Steering Group, “Option C (Modified) Parameters”, 2. See Appendix II - Supreme Court - Briefing Documents.
} 
location? The idea of standing at the bus stop and observing justice in the making is compromised by the layers of glass obscuring the view. An asymmetrical response, reinforcing the buildings' differences, would have been justifiable. This layout could have focused on the important Lambton Quay-Whitmore Street corner, diagonally opposite the Beehive and Parliament. The symbolic link between Court, Executive and Legislature could have been accentuated [...]. A strong corner would also have signalled the entry of this part of Lambton Quay from the north. ${ }^{156}$

As Blunt notes, the interior of the courtroom is visible from the exterior; standing at the entrance there is a perception of connection with the heart of the Court. While Blunt finds this connection somewhat compromised by the collocation of the entrance next to a major city bus stop, there is something special about this relationship between the exalted and quidotian, in observing justice being done at its highest level while carrying on one's daily routine. This connection is, of course, intentional; as noted in Chapter IV, the judges required a visual links from the bench to the exterior both horizontally and vertically. It is suggested also that compromise in this context is inevitable; the steps up to the entrance, the horizontally deep reflecting pools, bullet-proof glazing and steel bollards necessarily secure the building from trespass. The break made in the Supreme Court design from the tradition of fully enclosed and isolated courtrooms is significant and should not be underrated. ${ }^{157}$

156 Wilson, et al., "Natural Justice”, 60.

157 WaM wished to see the Supreme Court set back more considerably from Lambton Quay, but "other [political] powers said no. [...] When [they] say no, well [they] say no and that's the decision that was made and you've just got to live with it." Wilson, discussion. Indications of how the siting might have been are evident in the proposals illustrated in the Minister for Courts March 2006 Cabinet paper (see Appendix II). 




Ill. 38 Supreme Court, bronze screen and reflecting pool 


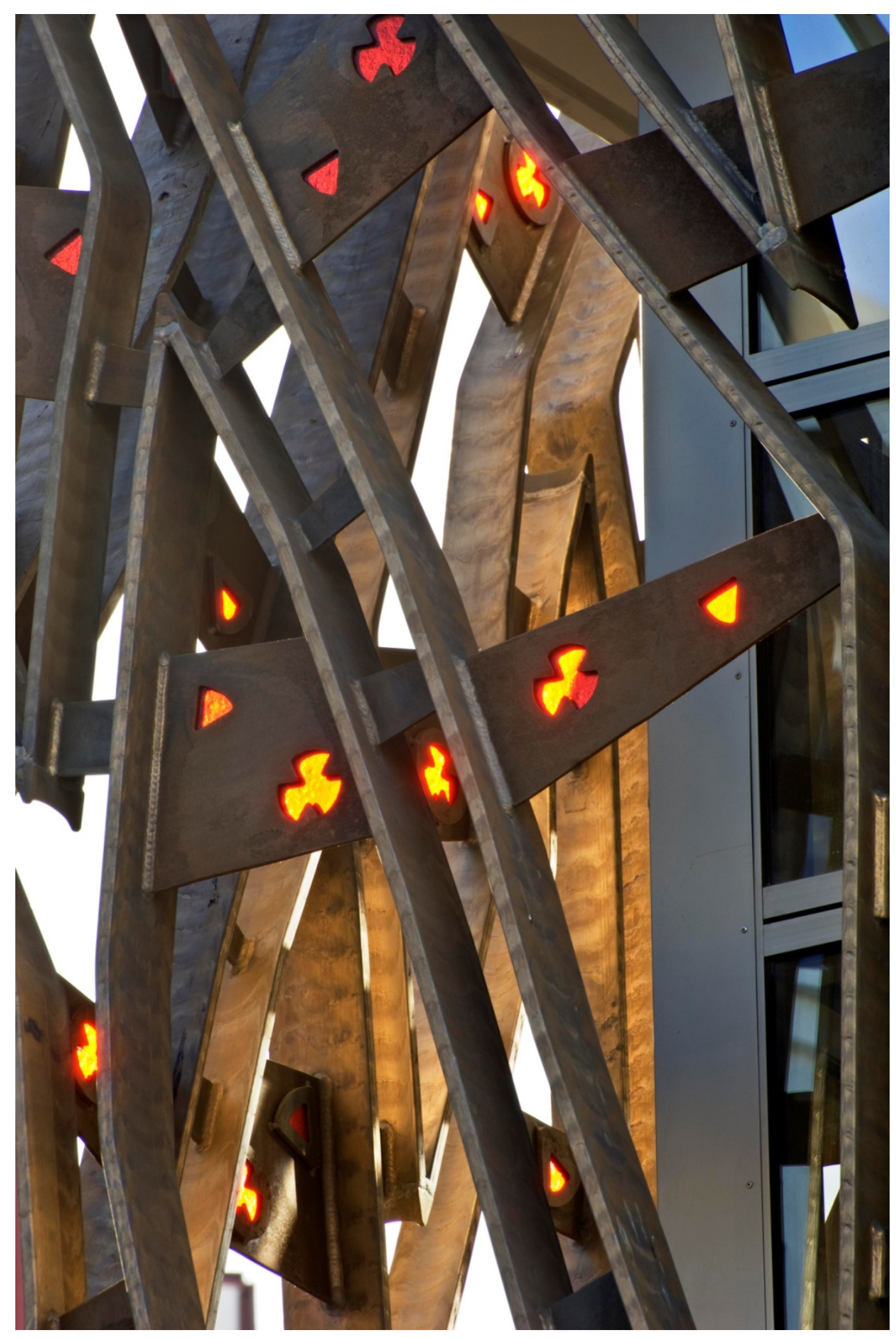

Ill. 39 Cast glass "blossoms" catch the evening light 


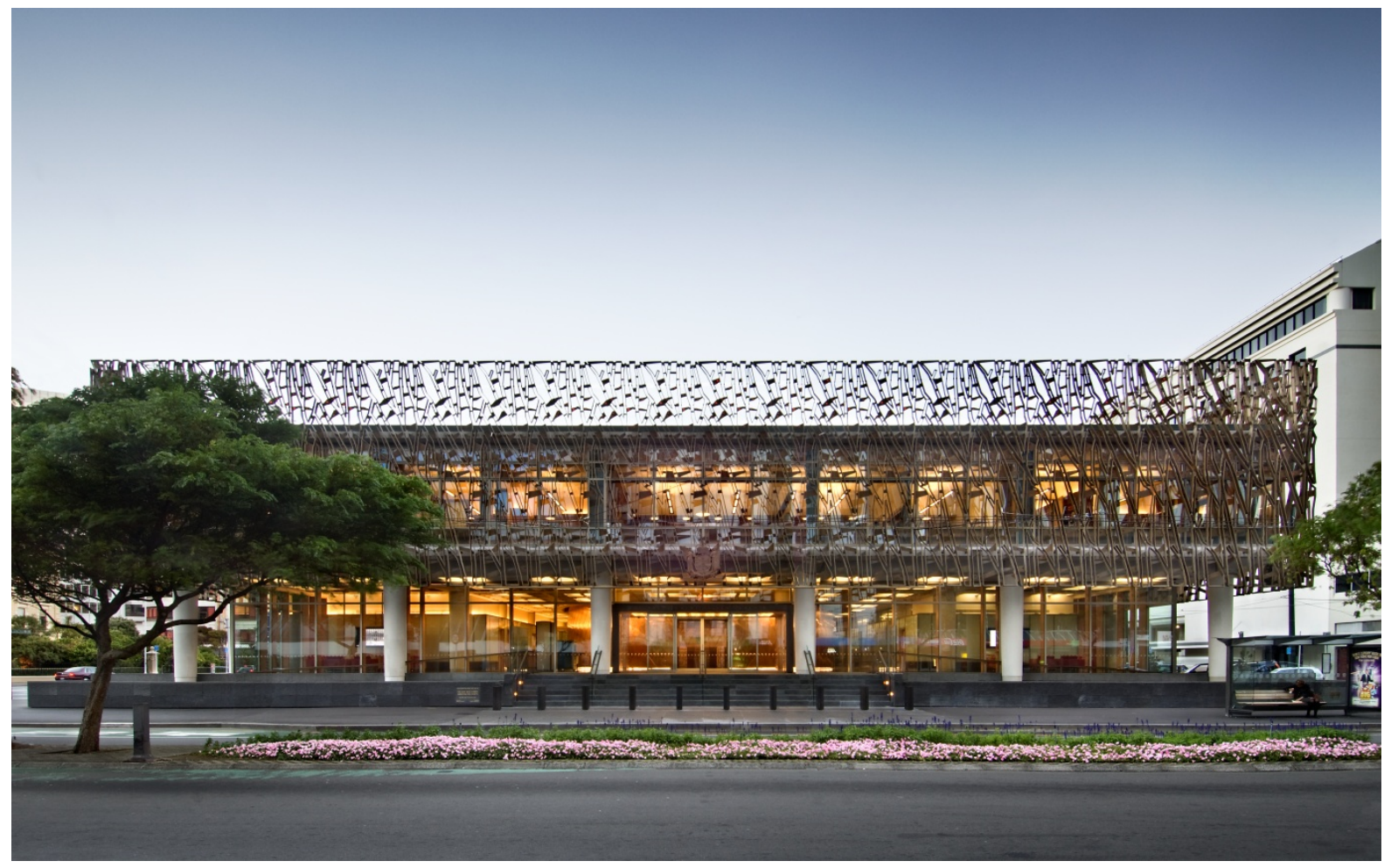

Ill. 40 Supreme Court entrance on Lambton Quay

After entering the building through the main doors (or via the security scanner to the left of the main doors when the Court is sitting (Ill. 41), one enters the spacious public lobby (Ill. 42). The restrained material palette of the Supreme Court building of concrete and stone, timber and glass, and copper and bronze is appreciable in this space, materials intended to have substance and longevity, materials that have a life and "mana"158 of their own.

158 Wilson, discussion. 


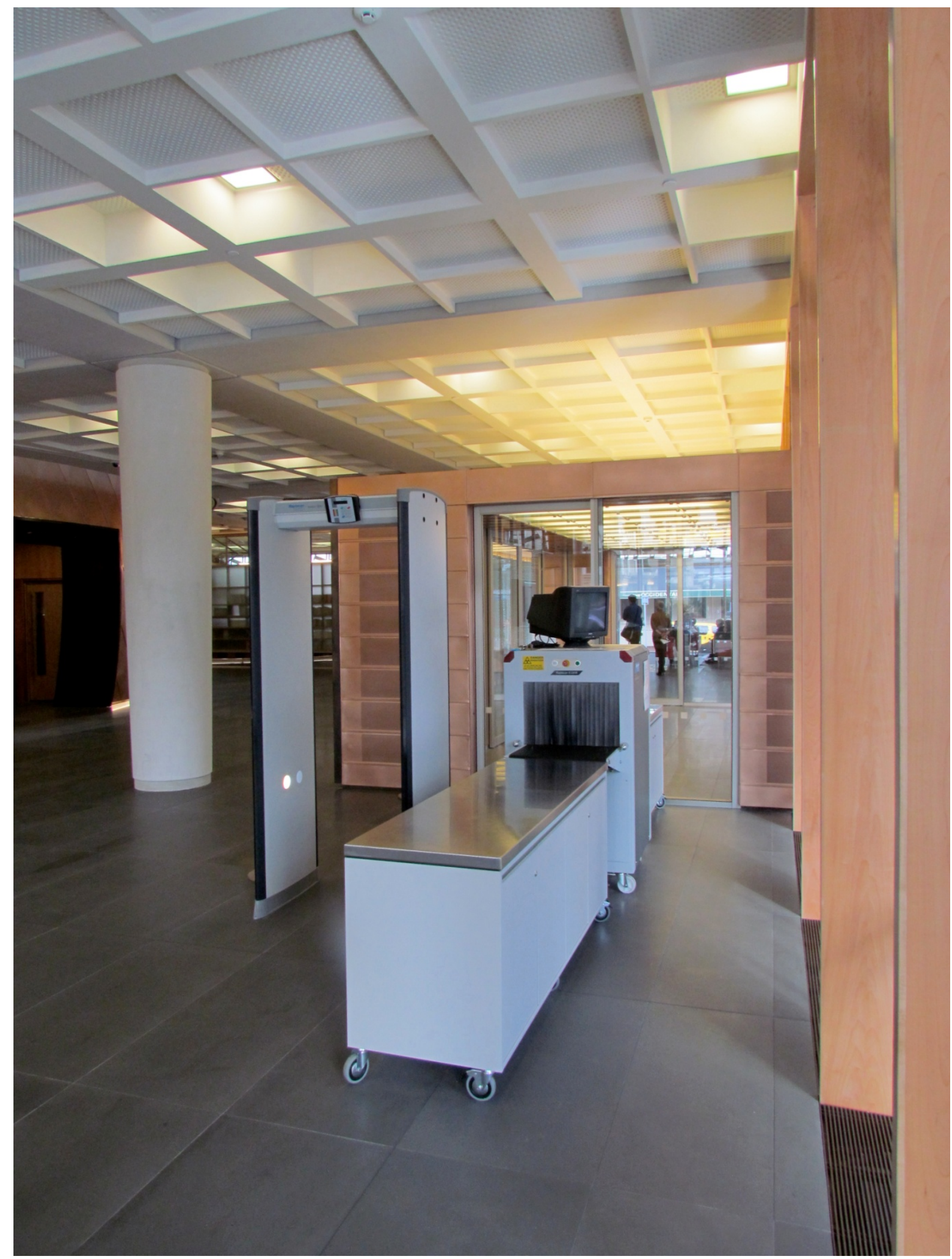

Ill. 41 Supreme Court security scanner 


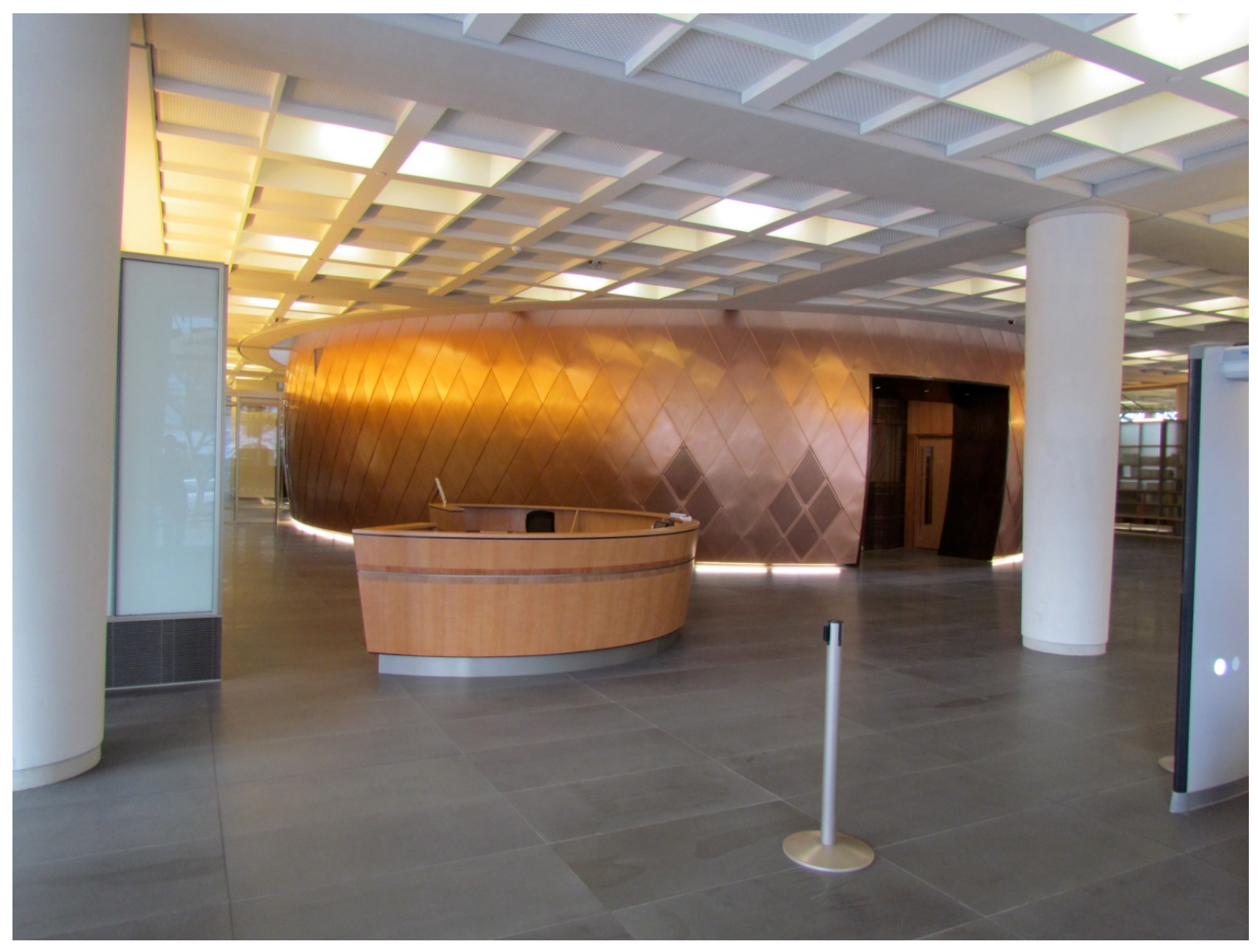

Ill. 42 Concierge's desk in the Supreme Court lobby

Visitors are immediately struck by the primacy of courtroom; the unmistakable focus of this space is the ovoid, copper-clad courtroom (Ill. 43). To the left and right in the reception area are large flat screen televisions which show a recording for visitors about the design of the Supreme Court and the OHCB restoration or relay the proceedings before the Court when it is sitting (Ill. 44). Visual connection to the exterior inverts the prior relationship of outsiderlooking-in to insider-looking-out, while, to the right of the courtroom, interior glazing gives a backlit, opaque view of the goings on within the Supreme Court library (Ill. 45). To the left of the courtroom one finds the reception desk, and a small, somewhat non-descript wall penetration that is the Supreme Court Registry counter (Ill. 46). 


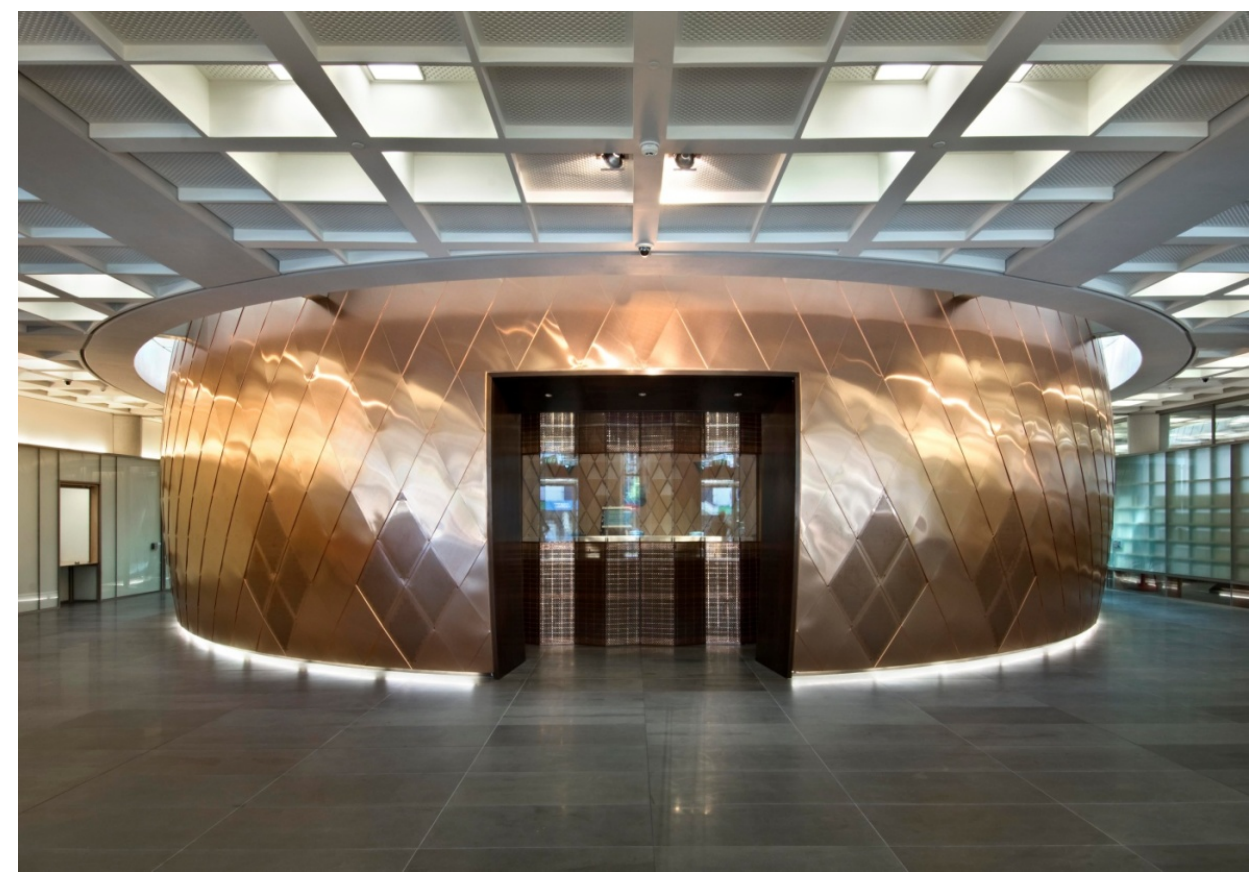

Ill. 43 Exterior of the Supreme Court courtroom

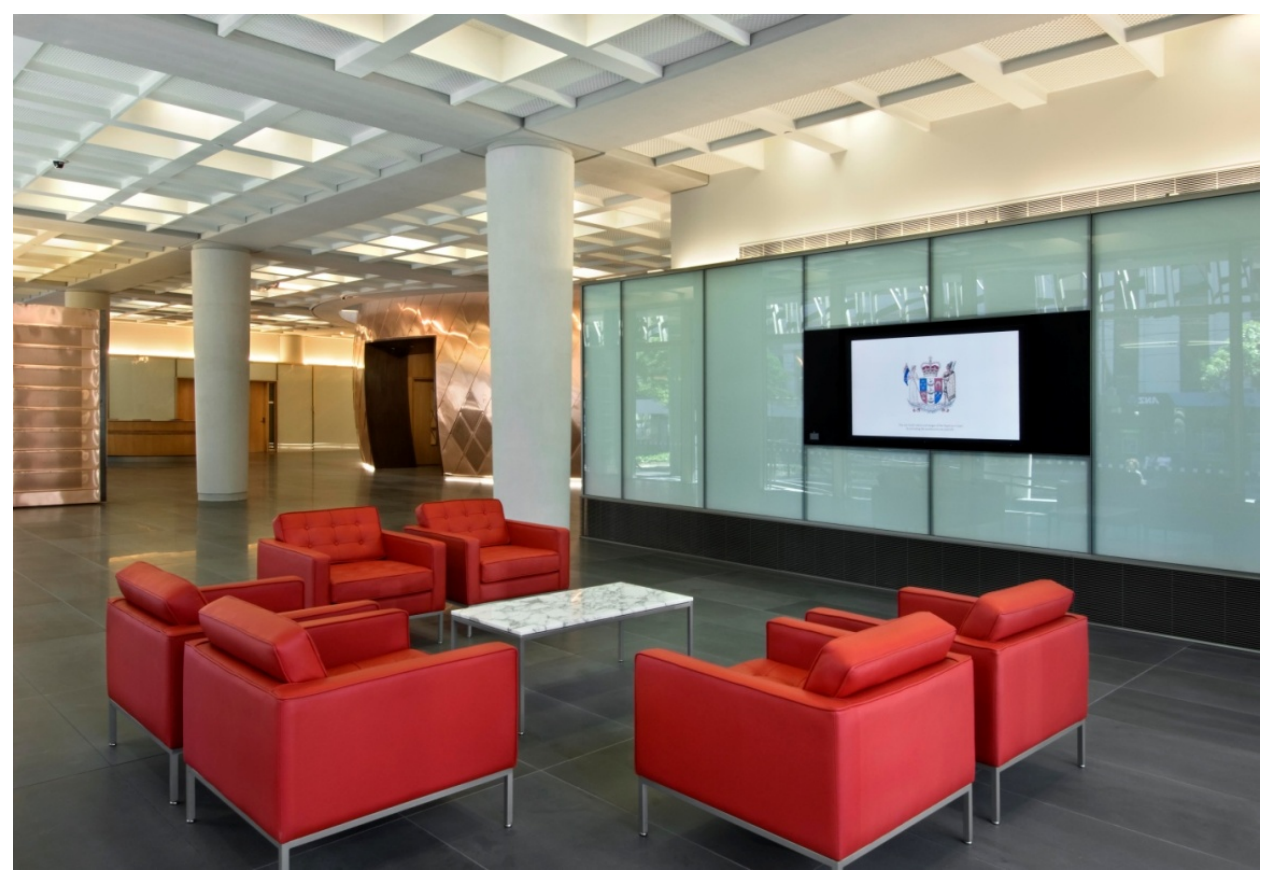

Ill. 44 Information screens in the Supreme Court lobby 


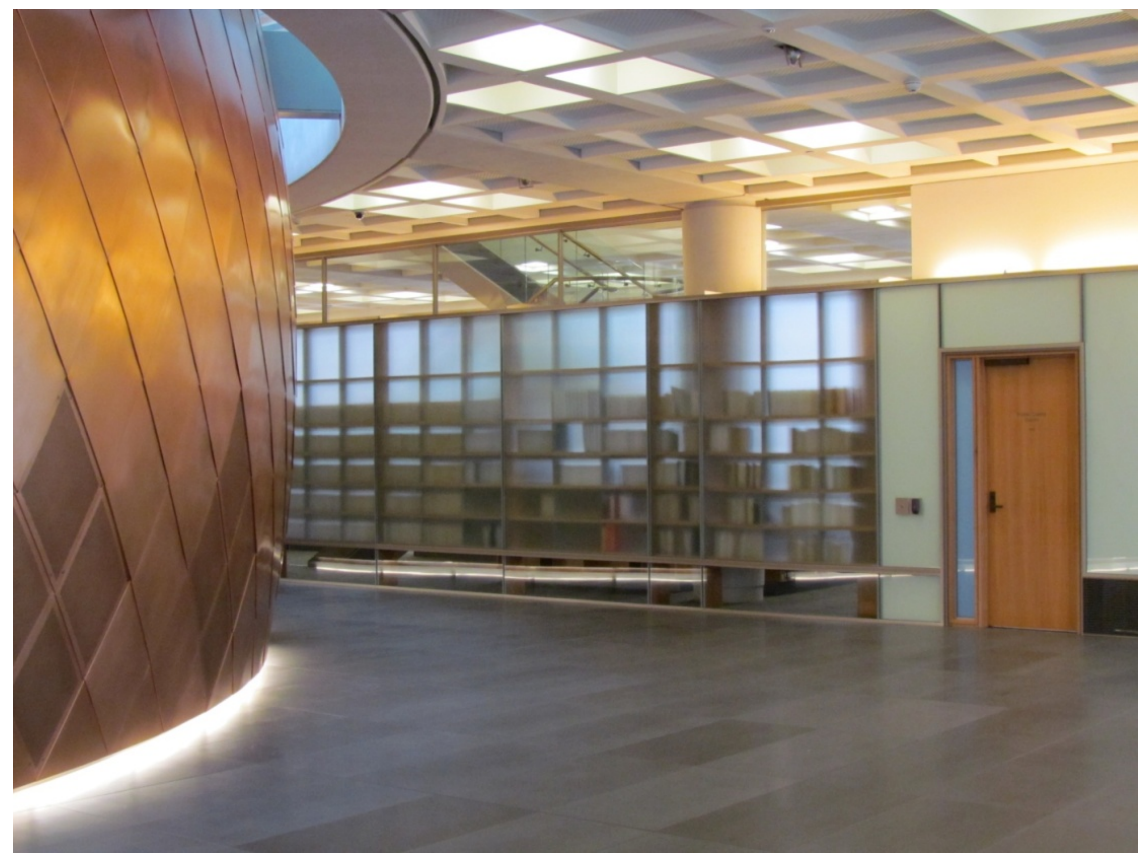

Ill. 45 Supreme Court library viewed from the lobby

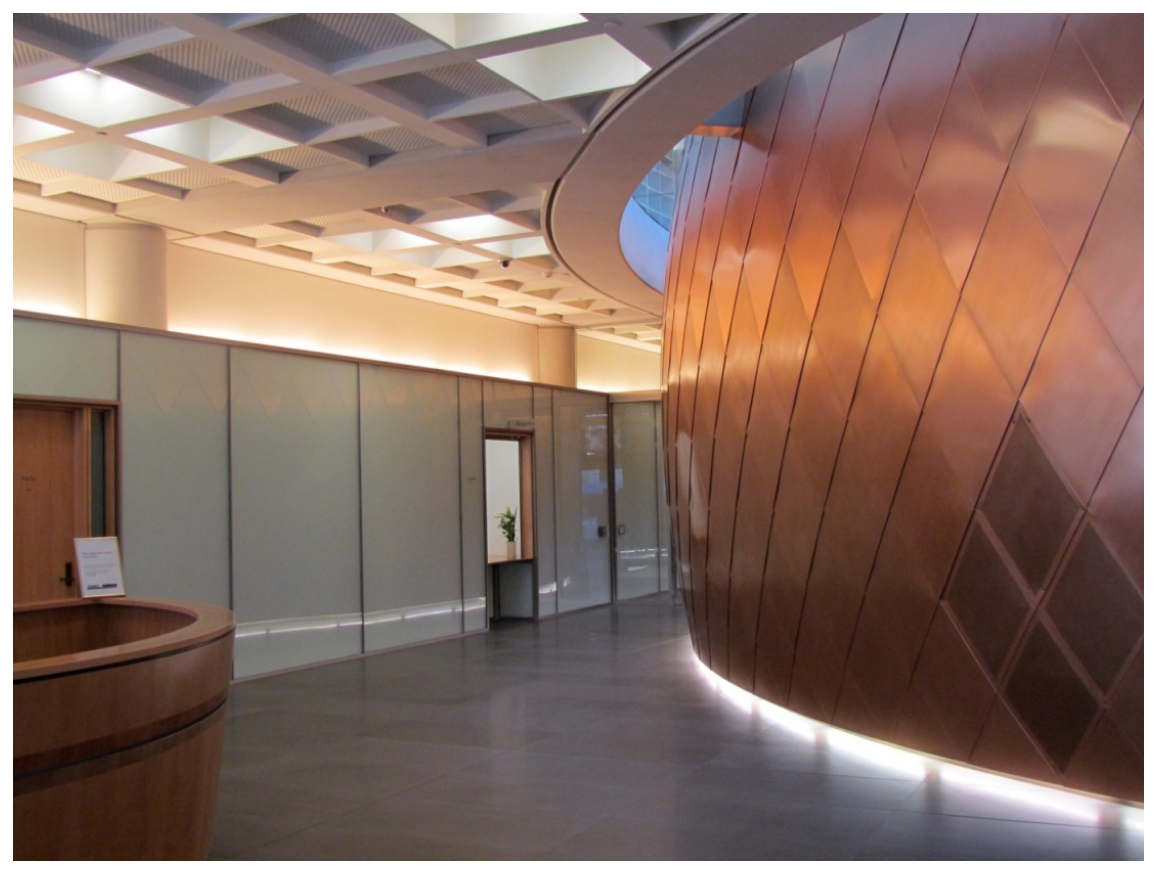

Ill. 46 Supreme Court Registry counter 
A concierge usually sits at the reception desk prepared to direct visitors to their destinations or give free tours of the Court to those interested. A room adjacent to the reception desk is reserved for media. Half way around the circumference of the courtroom, public access stops. Beyond the security lock are the Registry offices, meeting rooms, and a staff common room to the left; the library to the right; and behind the courtroom a spiral staircase and elevator provide access to the basement and first floor (Ill. 47).

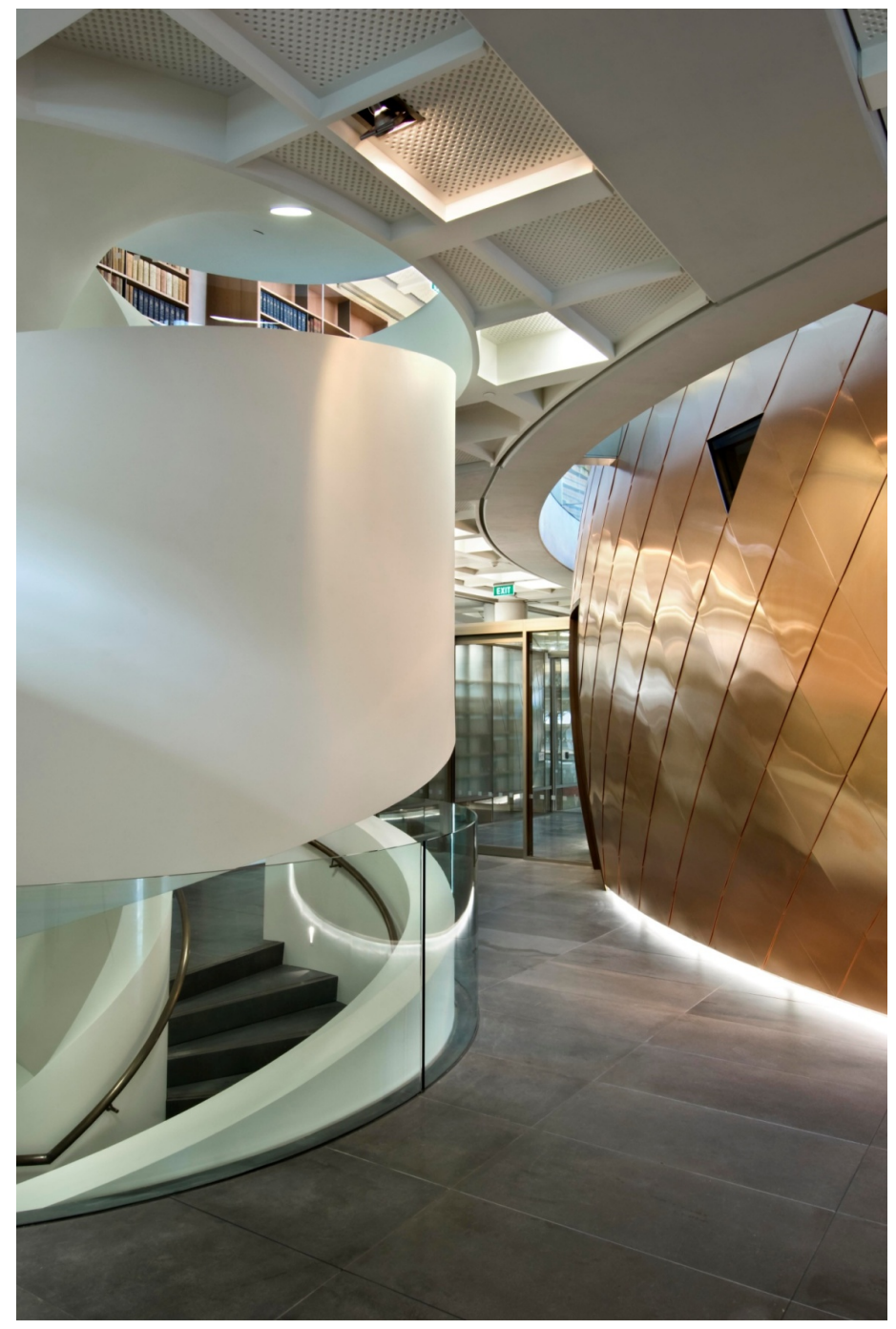

Ill. 47 Supreme Court spiral staircase 
Many people consider that the highlight of the Supreme Court is its courtroom. Indeed many laypeople would equate the courtroom with the Court, so it is fitting that the building's most expressive aspect be that space. The ritual of the courtroom can be observed from the reception area through a penetration glazed with dual-glazed, switchable glass which allows the judges to screen the courtroom from view with the flick of a switch, if required for confidentiality reasons (Ill. 48). ${ }^{159}$

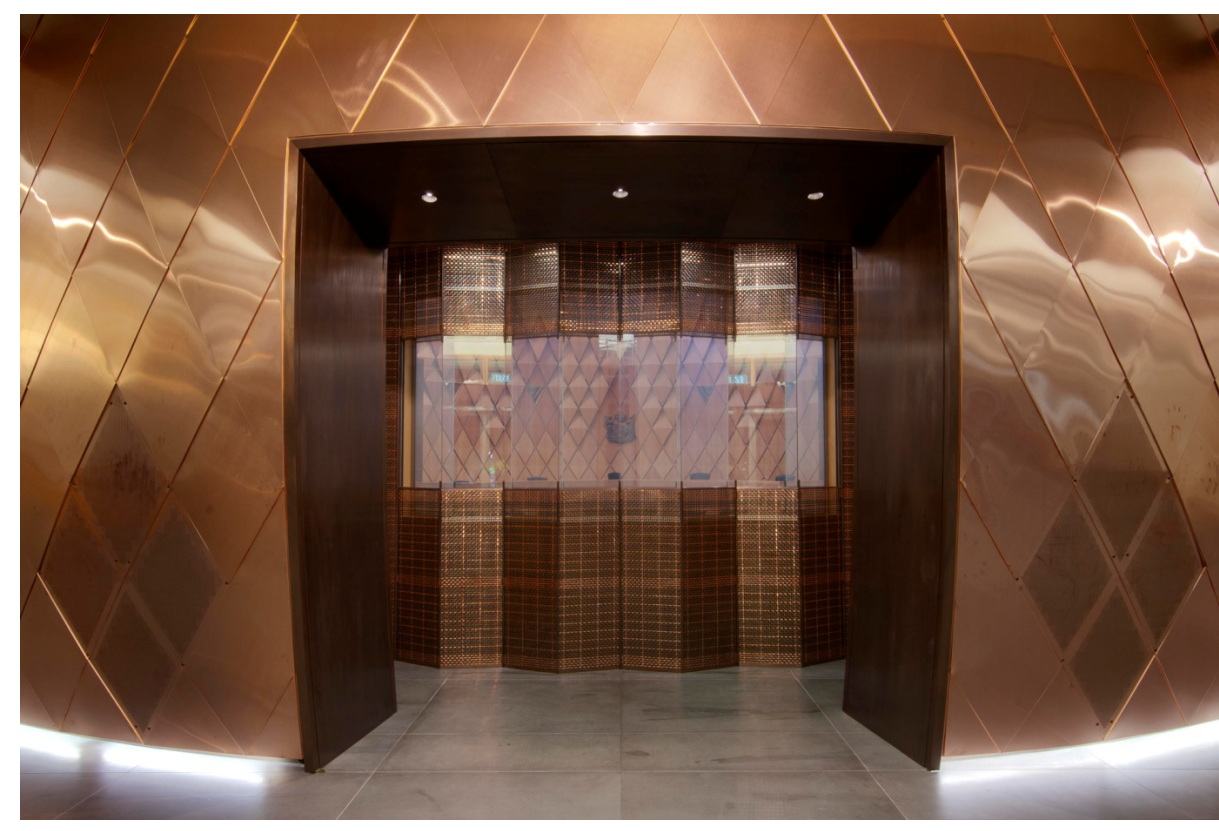

Ill. 48 Visual access from lobby to Supreme Court bench

Counsel and the public enter the rear of the courtroom at this point (Ill. 49). Externally clad in articulated copper sheet, some 2300 panels of sustainably harvested New Zealand silver beech clad the interior of the courtroom, which the architects state was influenced by the

\footnotetext{
${ }^{159}$ While the Court normally operates with full public access, on occasion cases will be heard in closed court, for example where suppression issues arise. Photographic or audio-visual recording devices are not permitted in the courtroom when sitting, even under normal circumstances.
} 
cone of the New Zealand kauri tree and commentators have remarked suggests "the idea of the court as the seed of a new tradition in New Zealand"160 (Ill. 50 \& 51).

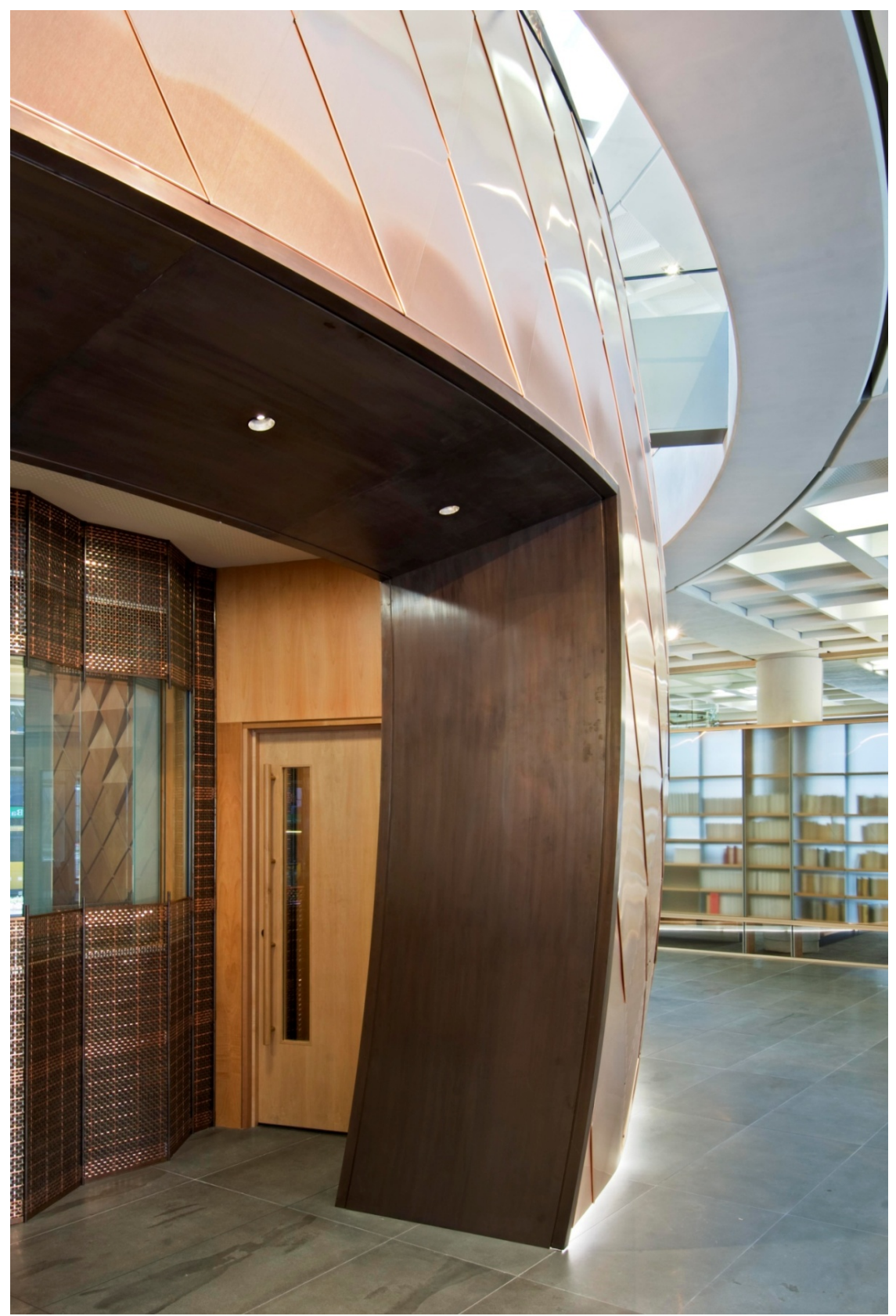

Ill. 49 An entry to the Supreme Court courtroom

160 Wilson, et al., "Natural Justice," 52. 


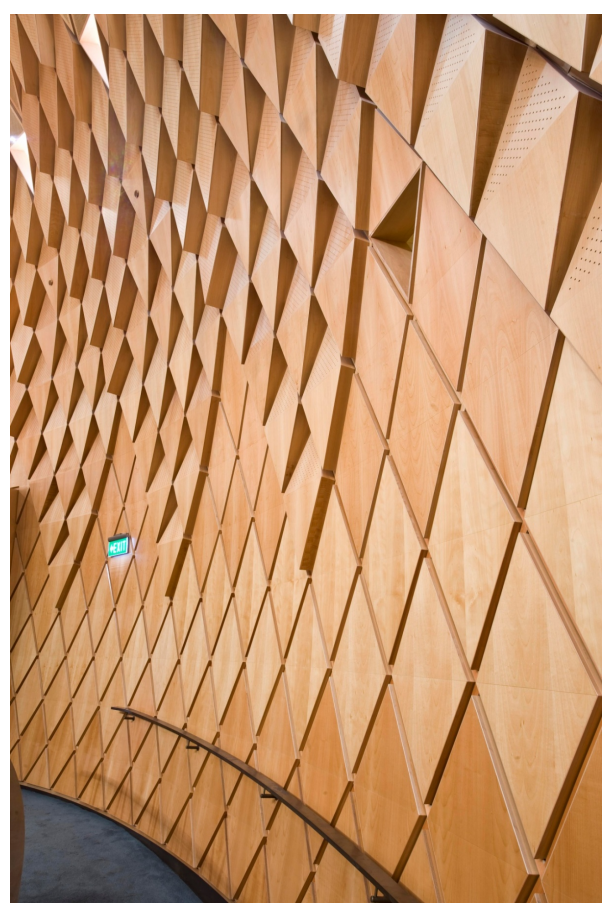

Ill. 50 Beech panels lining the Supreme Court courtroom

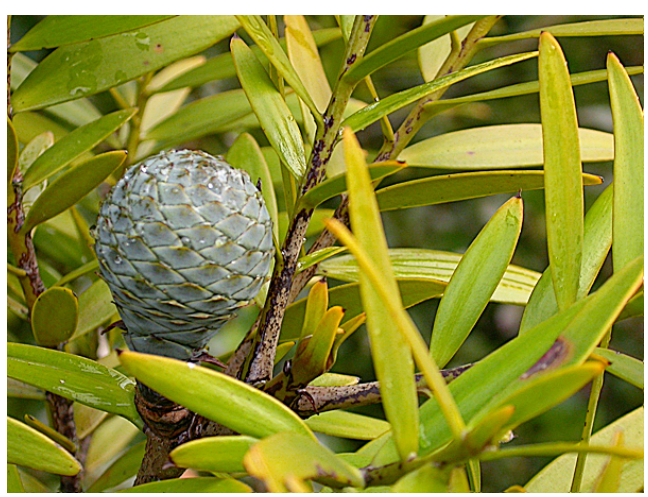

\section{Ill. $51 \quad$ Female cone of the kauri tree}

While the panelling might have been "influenced" by the kauri cone, this was by accounts a late addition to the court's referential repertoire. The courtroom was originally to be lined with timber slats but that intention was reconsidered after the judges pointed out the problems encountered by legal counsel in the Court of Appeal, which has a similar lining behind the bench. The parallel lines in the Court of Appeal courtroom lining cause what is known as a moiré pattern effect, a visual distortion caused by stong visual lines which, when 
in one's field of vision for an extended period of time, cause the lines to appear to distort, an understandably disconcerting situation for counsel attempting to present legal arguments for any length of time (Ill.52). The diamond pattern of the Supreme Court courtroom interior came about as a solution to avoid this effect. The carefully articulated surface assists in meeting the highly particular acoustic characteristics required of the courtroom. ${ }^{161}$

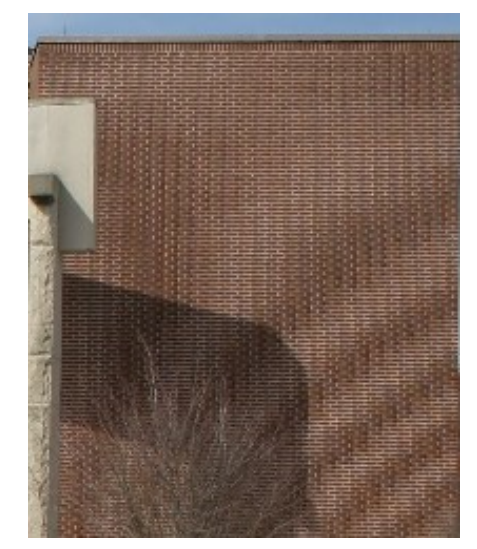

Ill. 52 Moiré effect in brickwork

The technical brilliance of the courtroom's ovoid design is evident in the perfect pairing in section of interior and exterior panels, which permits glazed penetrations through the skin for daylight access. These penetrations allow ambient light from the ground and first floors into the courtroom, but their placement just below the finished ceiling height of the floors intersecting with the courtroom prevents a goldfish-bowl viewing of the judges at work (Ill. $53 \& 54) .{ }^{162}$ Further daylight access is provided by the skylight at the apex of the courtroom, creating an axis mundi from the courtroom to the sky and the occupants an additional link with the outside world, while mechanical louvres can be engaged to prevent direct light

\footnotetext{
161 Wilson, discussion; Hampton/Jeppesen, discussion.

162 The ground floor also has elevated glazed penetrations through the cone for daylight access.
} 
penetrating the courtroom (Ill. 55). What at first appears to be an ornate light diffuser in the skylight is actually an acoustic reflector.

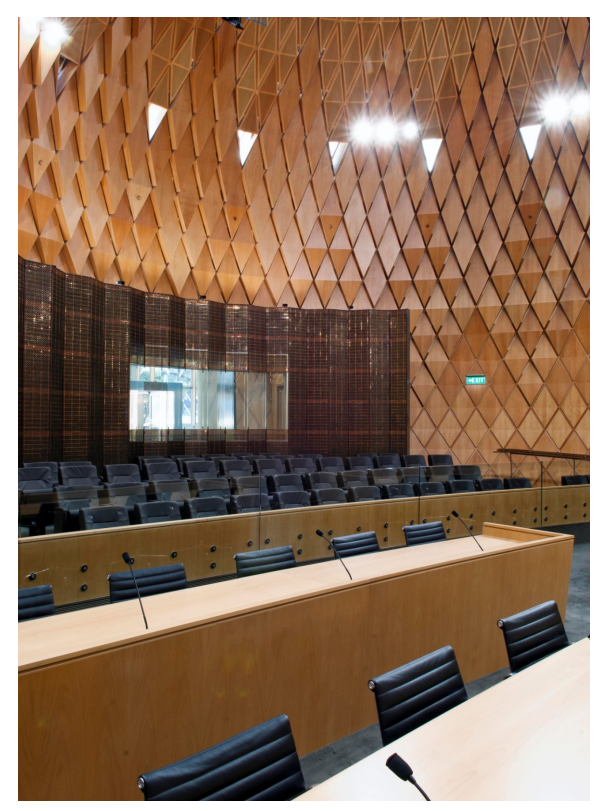

Ill. 53 Courtroom wall penetrations (interior)

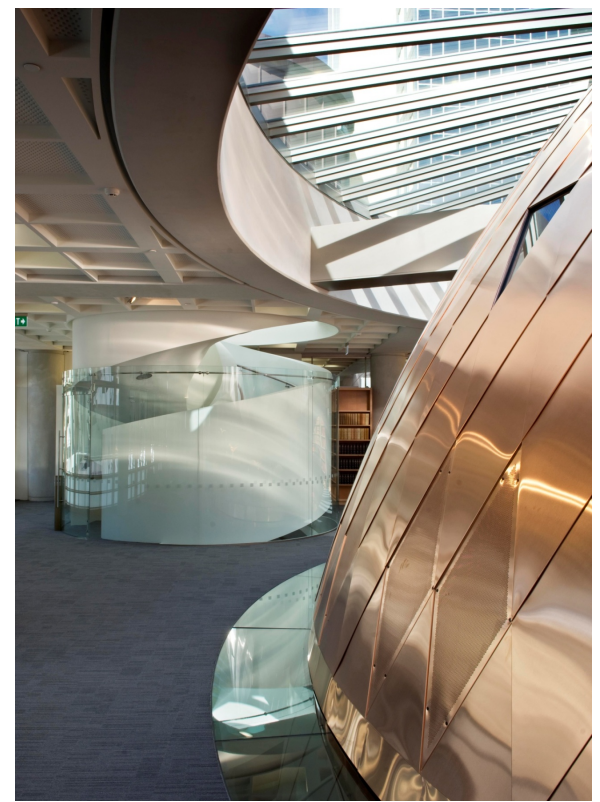

Ill. 54 Courtroom wall penetrations (exterior) 


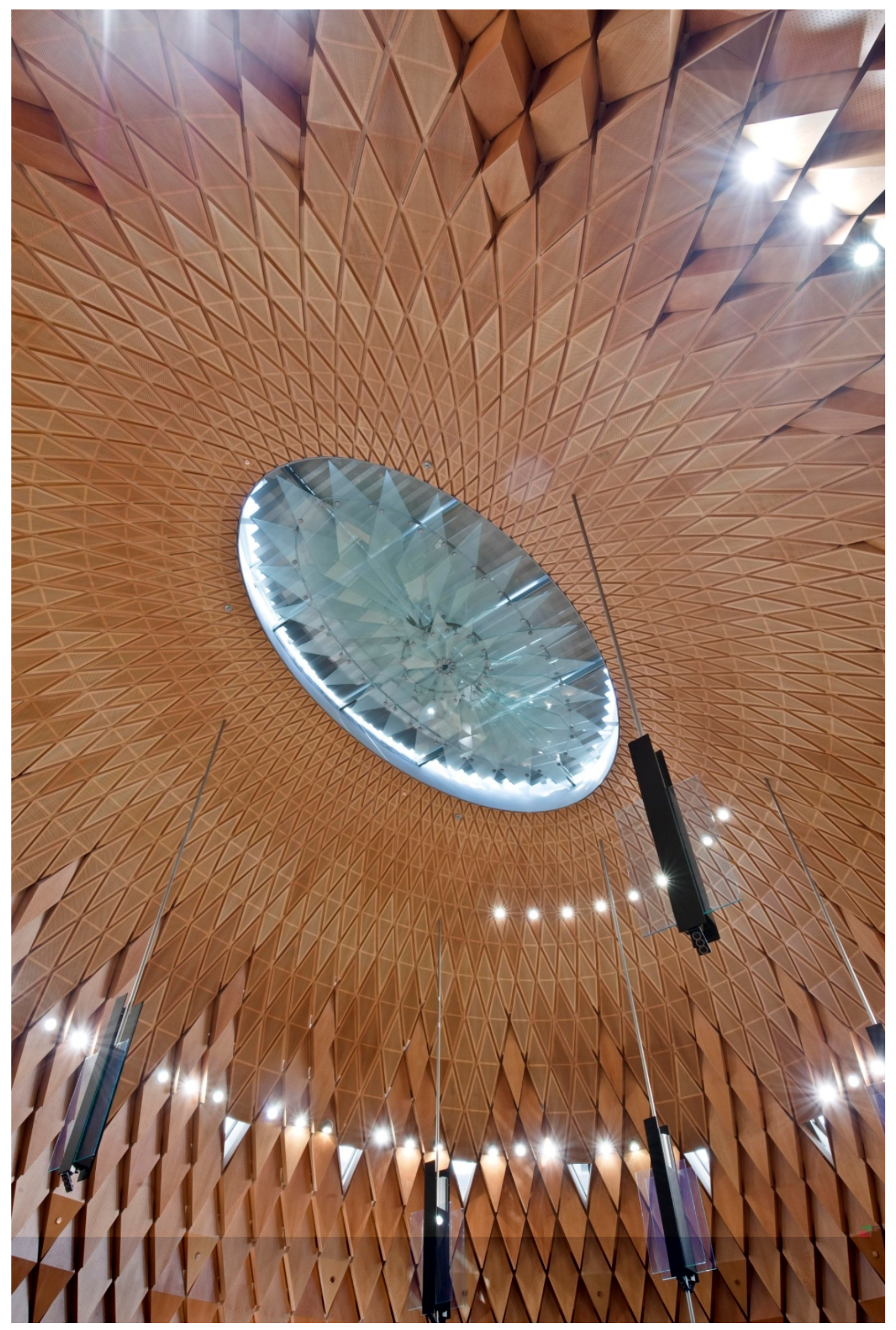

Ill. 55 Courtroom skylight with louvres closed behind the acoustic reflector 
It has been suggested that the acoustically reflective copper screens to the left and right of the bench recall tukutuku panels in traditional M ori carved houses, ${ }^{163}$ thus being symbolic of the $\mathrm{M}$ ori culture in New Zealand. Just as tukutuku panels evolved as a means of disguising less aesthetically-pleasing elements within traditional carved meeting houses ${ }^{164}$ so the copper screens hide audiovisual equipment occasionally employed by the court for electronic display of evidence or videoconferencing (Ill. 56).

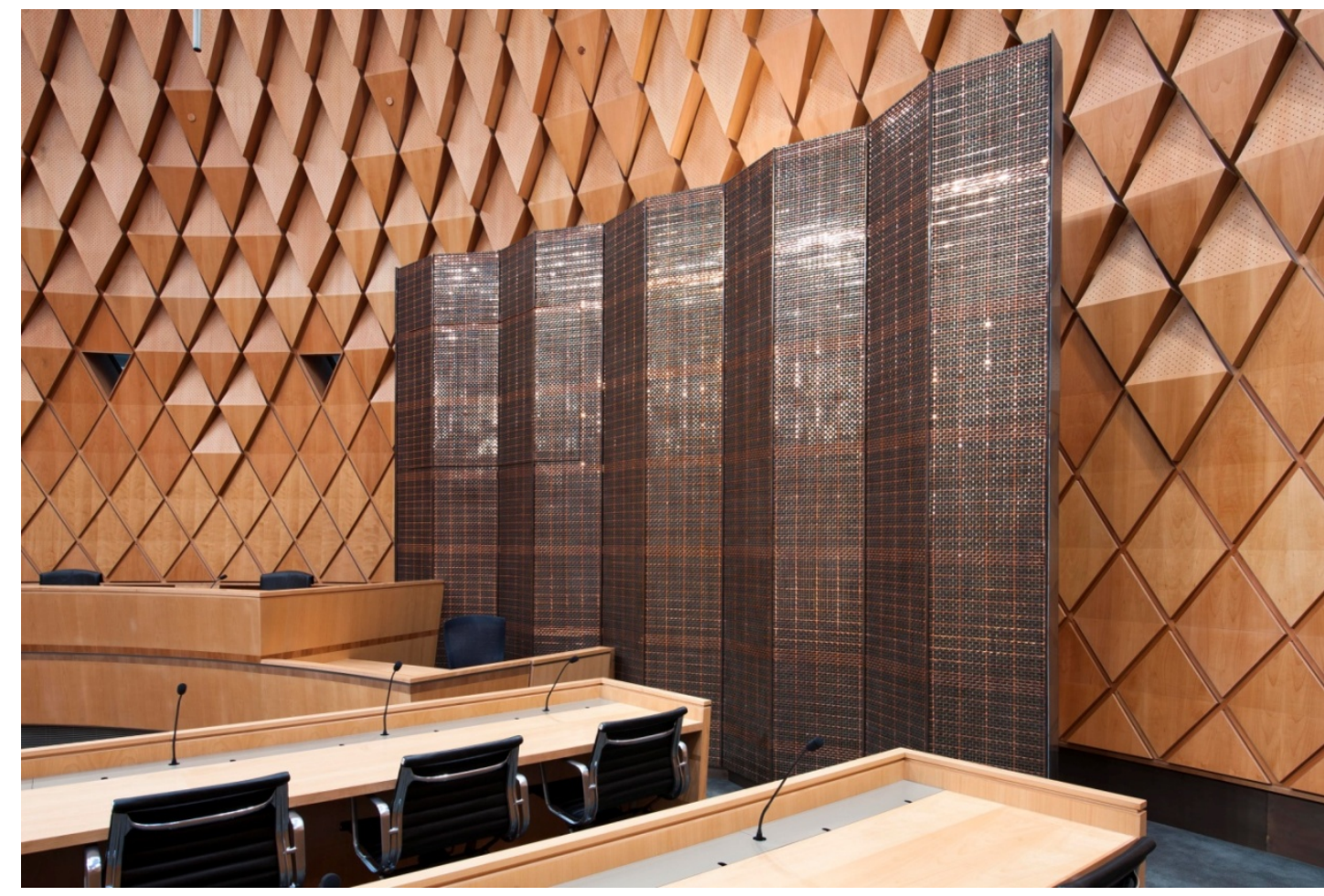

Ill. 56 Tukutuku panel-inspired acoustic screens

163 Wilson, discussion. See also Ministry of Justice, The Design of the New Building http://www.courtsofnz.govt.nz/about/supreme/the-supreme-court-complex/the-design-of-the-new-building. Tukutuku panels are ornamental lattice-works used particularly between carvings around the walls of Maori meeting houses. Traditional patterns have names and symbolic meanings. See p 156 (Ill. 83) below and http://christchurchcitylibraries.com/Maori/Puawaitanga/Stories/

${ }^{164}$ Julie Paama-Pengelly, Mäori Art and Design: Weaving, Painting, Carving and Architecture (Auckland: New Holland, 2010), 34 . 
The idea of having tukutuku panels in the courtroom came from the judiciary, as MoJ officials explained:

There was a range of views of comfort among the judges as to the extent to which the building should reference M ori culture. I think everyone agreed that it shouldn't be viewed as being the preserve of any single iwi, but given that $\mathrm{M}$ ori are New Zealand's first people it was probably appropriate that there was some recognition of that. And so the debate was less about the outside of the building and more about the inside. The Chief Justice liked the idea of something being done like had been done in the $\mathrm{M}$ ori Affairs Select Committee room where tukutuku panels had been produced by various iwi around the country, so that dealt with the issue of it not being representative of any one particular group [...]. I think Roy [Wilson] picked up on that [in the copper screens] which reference tukutuku panels. The Chief Justice quite liked that. People quite liked that this was something you could expect to see in a modern marae, but wasn't necessarily attributable to one iwi. ${ }^{165}$

Planning and acoustics provide a more intimate relationship between bench and counsel (and the public gallery) than New Zealand courtrooms have previously enabled. The curve of the bench (which seats five judges at a time) was a request of the judges who wished to have better sightlines between each other while hearing cases and represents a notable departure from traditional courtroom planning (Ill. 57). This curve has been continued through the courtroom creating a greater feeling of in-the-round participation than the traditional rectangular courtroom planning allowed. The outstanding acoustic performance of the room means that neither judges nor counsel nor public need strain to hear the proceedings clearly. ${ }^{166}$

\footnotetext{
165 Hampton/Jeppesen, discussion.

166 In the author's personal experience, people speaking at normal volume in the public seating can clearly be heard from the bench at the opposite end of the courtroom.
} 


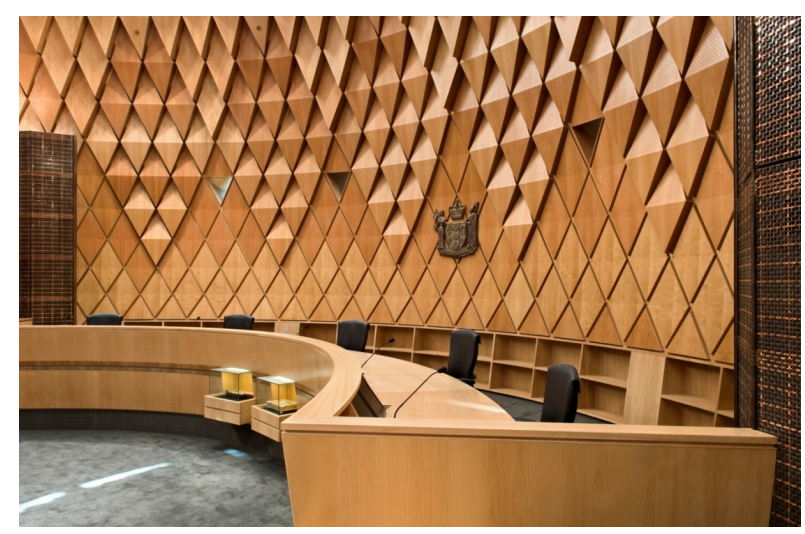

Ill. 57 Curved bench, New Zealand coat of arms, and glass cabinets

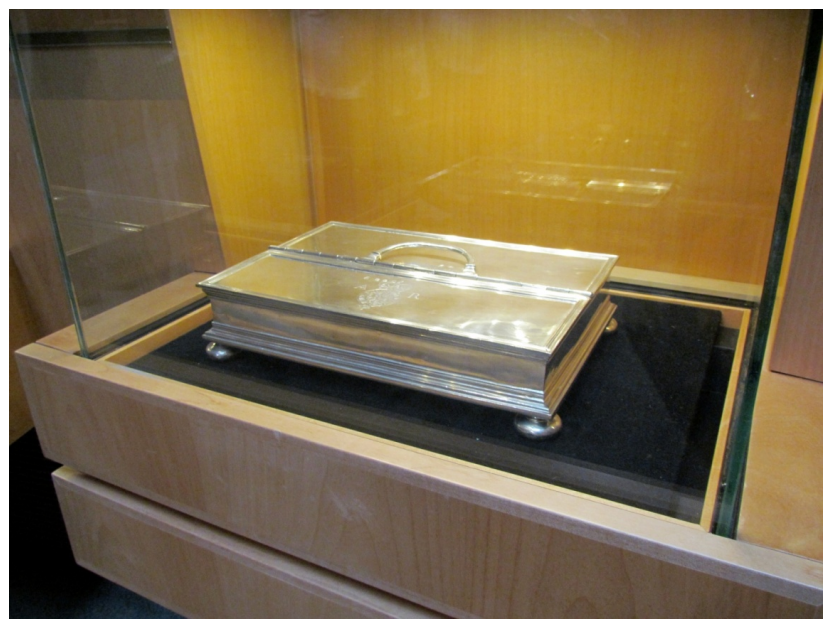

Ill. 58 Queen Anne inkwell

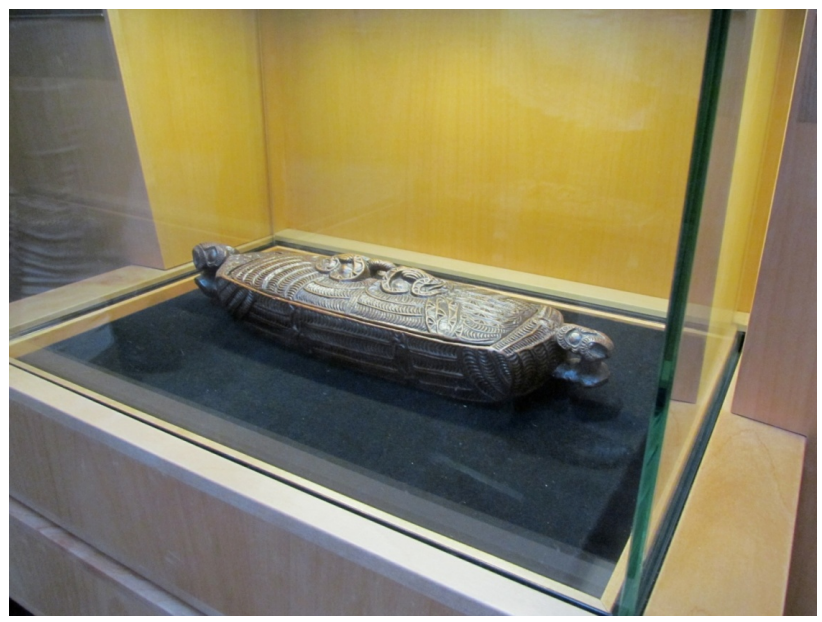

Ill. 59 Waka huia 
The bench is also the location of three of the key symbolic elements of the Supreme Court. First, the New Zealand coat of arms is prominently displayed on the wall behind the judges. Secondly, at the front of the bench are two glass boxes. One contains a sterling silver inkwell gifted to the Supreme Court by the Privy Council in 2004 which was given to the Privy Council by Queen Anne in 1702 (Ill. 58). The other contains a waka huia ${ }^{167}$ on loan to the Court from Te Papa Tongarewa/Museum of New Zealand, an indigenous counterpoint to the English inkwell (Ill. 59). The waka huia was chosen by Roy Wilson and the Chief Justice on grounds of its similarity in size and age, but also because the specific waka huia selected lacks verified provenance meaning that it can be viewed as a universal symbol of a time and culture. ${ }^{168}$ Together the inkwell and waka huia symbolise the twin ancestors of New Zealand's current legal system.

Access to the interior of the Supreme Court building beyond the courtroom is restricted to staff and judges. This area is spacious and primarily one for circulation, being both the understated link to the OHCB and the location of a glass elevator and the (unusually for this "light" building) massive spiral staircase leading to the first floor (Ill. 60). The first floor is the most restricted part of the Supreme Court building, unsurprisingly given that it is the daily workplace of the nation's most senior jurists. The judges required that the planning of

\footnotetext{
167 A "waka huia" is a vessel for containing objects of significance to the owner. The name relates to the tail feathers of the huia bird (now extinct) which were worn by $\mathrm{M}$ ori of chiefly status in times past.

168 Wilson, discussion. Some confusion exists as to the provenance of the waka huia. Wilson stated that its provenance is unknown (Wilson, discussion); MoJ officials and the Chief Justice, however, has stated that it is of Te Atiawa origin (Hampton/Jeppesen, discussion; Sian Elias, "Speech at the Opening of the Supreme Court of New Zealand” (18 January 2010) http:/ /www.courtsofnz.govt.nz/from/speeches-andpapers/\#speechpaper-list-2010)
} 


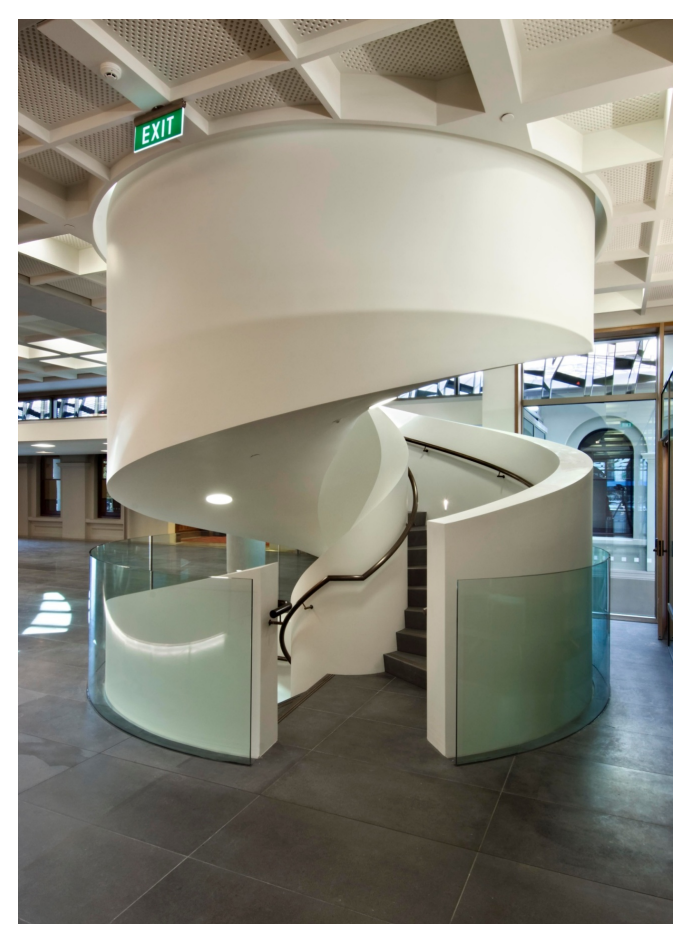

Ill. 60 Ground floor staircase (OHCB beyond)

their chambers promote collegiality between them; ${ }^{169}$ accordingly, the chambers are located around the perimeter of the building with open circulation around the courtroom which pushes through the floor level as it rises through the building (Ill. 61). A "collegial" room is also reserved for the judges to meet and deliberate on judgments collectively. Bookshelves line this circulation space giving it the feel of a modern public library while a glazed penetration in the floor describing the circumference of the courtroom permits a view to the ground floor (and vice versa) (Ill. 62). The curve of the courtroom's dome diffuses daylight through the space, and inviting movement around it (Ill. 63).

Returning to the ground floor, occupants are able to enter the OHCB through what was once a judge's chamber at the rear of the OHCB (Ill. 64). The exemplary restoration of the

\footnotetext{
${ }^{169}$ This approach had previously been explored by WaM in the Parliament Refurbishment project, where carefully secured corridors now mean that passing politicians can freely discuss issues in a relatively public space. Wilson, discussion.
} 
OHCB means that moving from the Supreme Court building into the OHCB is like stepping back in time.

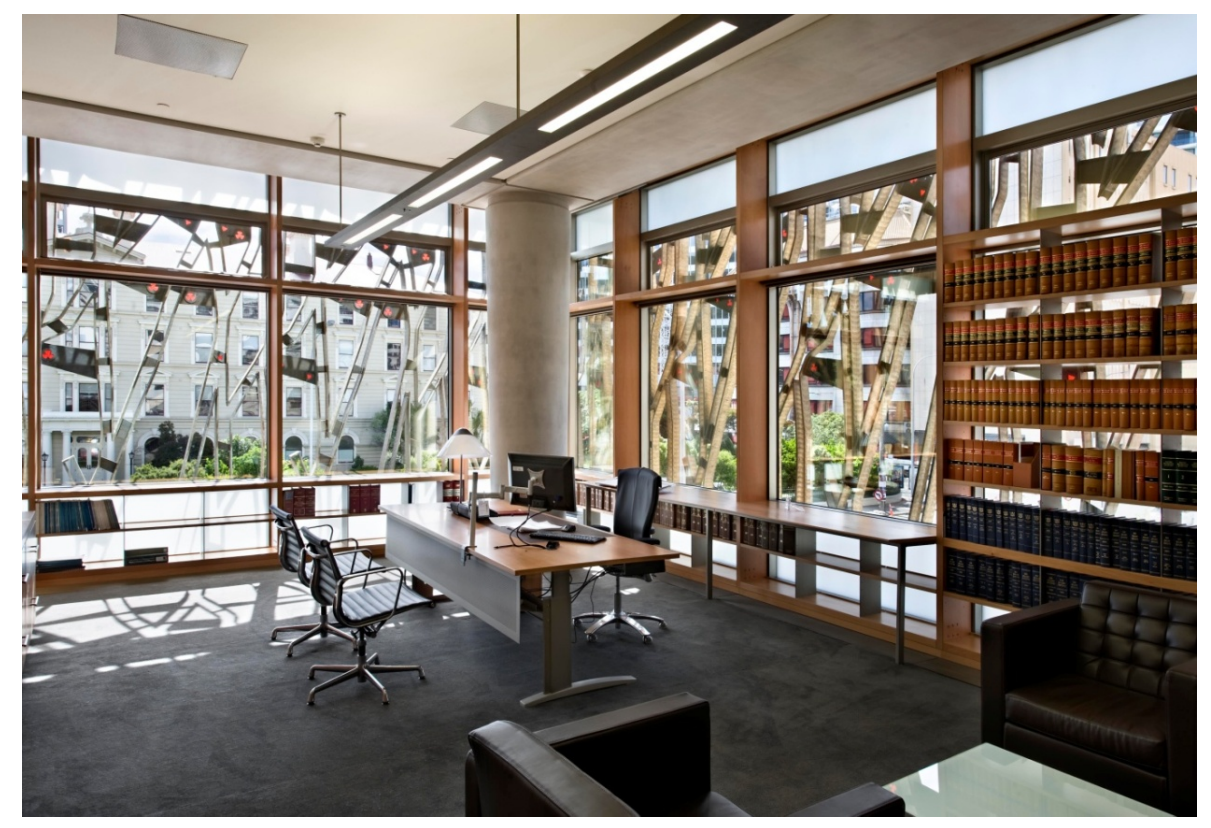

Ill. 61 Judge's chambers

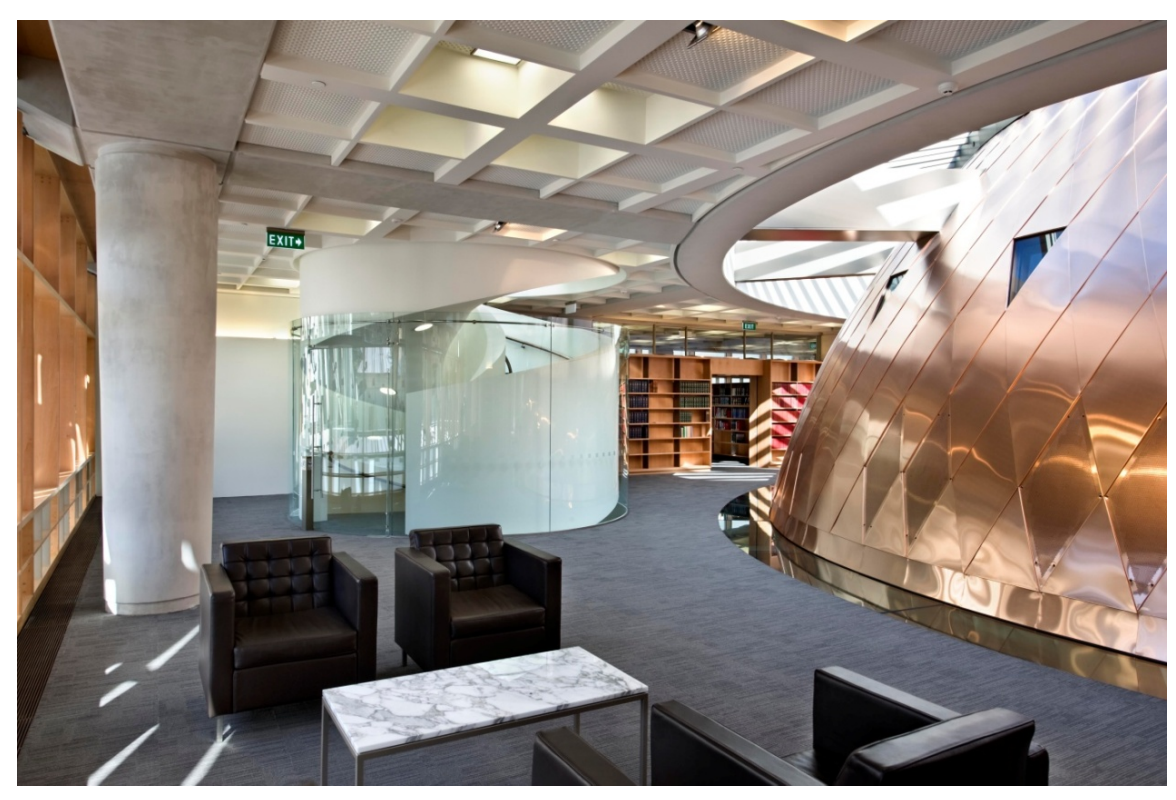

I11. 62 First floor circulation space 


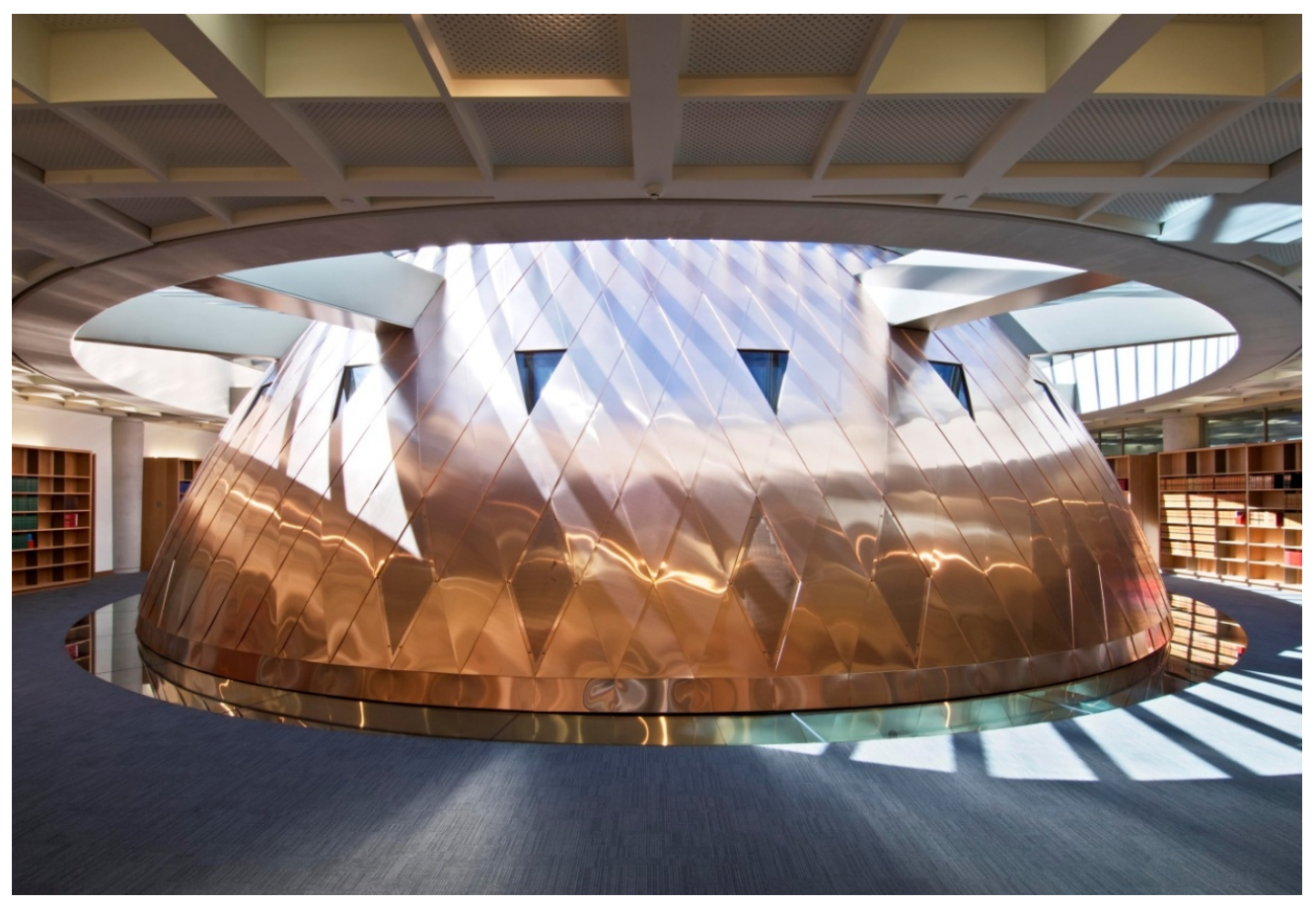

Ill. 63 Light reflected off the courtroom into the first floor circulation space

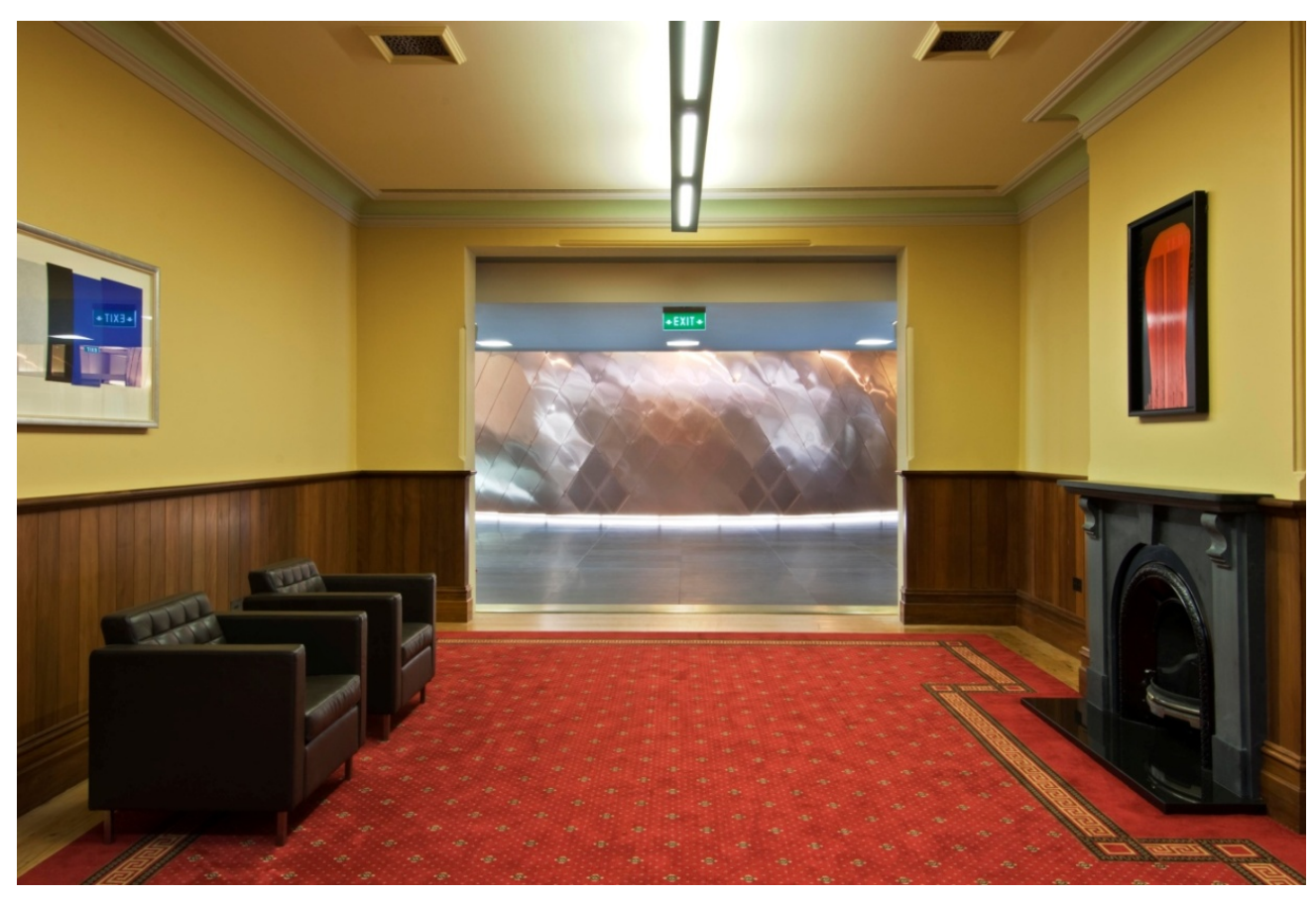

Ill. 64 Access between the Supreme Court and OHCB (former judge's chamber) 


\section{The Old High Court Building}

Designed in 1878 by Pierre Finch Martineau Burrows (the "de facto Government architect of the day"179) the OHCB functioned as a Supreme Court from its opening in 1881 until 1980 when it was renamed the High Court, and operated as such until 1993 when the current Wellington High Court building opened on Molesworth Street and the building was vacated. As noted in Chapter II, the OHCB was not the first Supreme Court in Wellington. The construction of Wellington's first Supreme Court building (located at the present-day intersection of Hunter Street and Lambton Quay) coincided with the shift of Government from Auckland to Wellington in $1865 .{ }^{171}$ It can be imagined that an expanding caseload being brought before the Court in the 1860s and 70s concomitant with the expansion of Wellington's population after it became the nation's capital meant that the original building quickly became too constrained for the Court's purposes. Cochran suggests also that the appointment in 1875 of Sir James Prendergast as New Zealand's first Chief Justice to be permanently stationed in Wellington necessitated more appropriate and dignified accommodation for the Supreme Court. ${ }^{172}$ The availability of vacant land created by reclamations begun in 1875 meant commissioning of a new courthouse occurred little more than 10 years after the opening of the first Supreme Court.

\footnotetext{
${ }^{170}$ Chris Cochran, Supreme Court. 42 Stout Street. Conservation Report for the Ministry of Justice (Wellington, New Zealand: 2006), 24. P F M Burrows succeeded Colonial Architect William Clayton but without the formal title.

${ }^{171}$ See p. 49 (Ill. 7 ).

${ }^{172}$ Cochran, Supreme Court Conservation Report, 39.
} 
As previously mentioned, the $\mathrm{OHCB}$ is a designated heritage building under the Wellington City District Plan and (since 1981) a Category I Historic Place on the NZHPT Register. ${ }^{173}$ It was the first major masonry building in Wellington and originally the brick bearing walls rested on mass concrete footings supported by foundations of stout totara piles. ${ }^{174}$ The NZHPT describes the building as a "scholarly work having dignity and good proportions in its [Victorian] neo-classical style" which is "well mannered" and "relates happily to the adjacent Government Building of W H Clayton." ${ }^{175}$ The cultural heritage significance of the OHCB is undeniable. Conservation architect Chris Cochran notes the building has had a long association with administration of justice in New Zealand and is exemplary of a history of architectural change and adaptation over 130 years. ${ }^{176}$ Cochran's Supreme Court Conservation Report provides a remarkably comprehensive architectural, historical and cultural description of the OHCB. Appendix III contains excerpts from Cochran's report which describe the architectural history, structure, planning, finishes, additions and services of the OHCB prior to its restoration, together with some relevant historical and contemporary architectural drawings. ${ }^{177}$

\footnotetext{
${ }^{173}$ It should be noted that the heritage protections given to the OHCB prior to its use in the Supreme Court project extended only to the facade of the building. The entire building (including interior finishes) became protected under the designation of the Supreme Court complex site by the Wellington City Council in April 2007. See Wellington City Council, “Council Decision - Notice of Requirement: Supreme Court of New Zealand” (12 April 2007) (Wellington, New Zealand).

${ }^{174}$ NZHPT, "High Court Building (Formerly Supreme Court Building”

http://historic.org.nz/TheRegister/RegisterSearch/RegisterResults.aspx?RID=219\&m=advanced

175 Ibid.

176 Wilson, et al., "Natural Justice," 54.

177 Cochran, Supreme Court Conservation Report. The report was originally written for the MoJ in October 2006 and revised in March 2007 for the Supreme Court project.
} 
The courthouse originally had an expansive and unimpeded view to Lambton Harbour from its main entrance off Stout Street (Ill. 65). There were three significant additions to the building designed by Government Architect John Campbell - two additions in 1907 and one in 1913 - which emulated the neo-classical style of Burrow's original design, although it has been noted

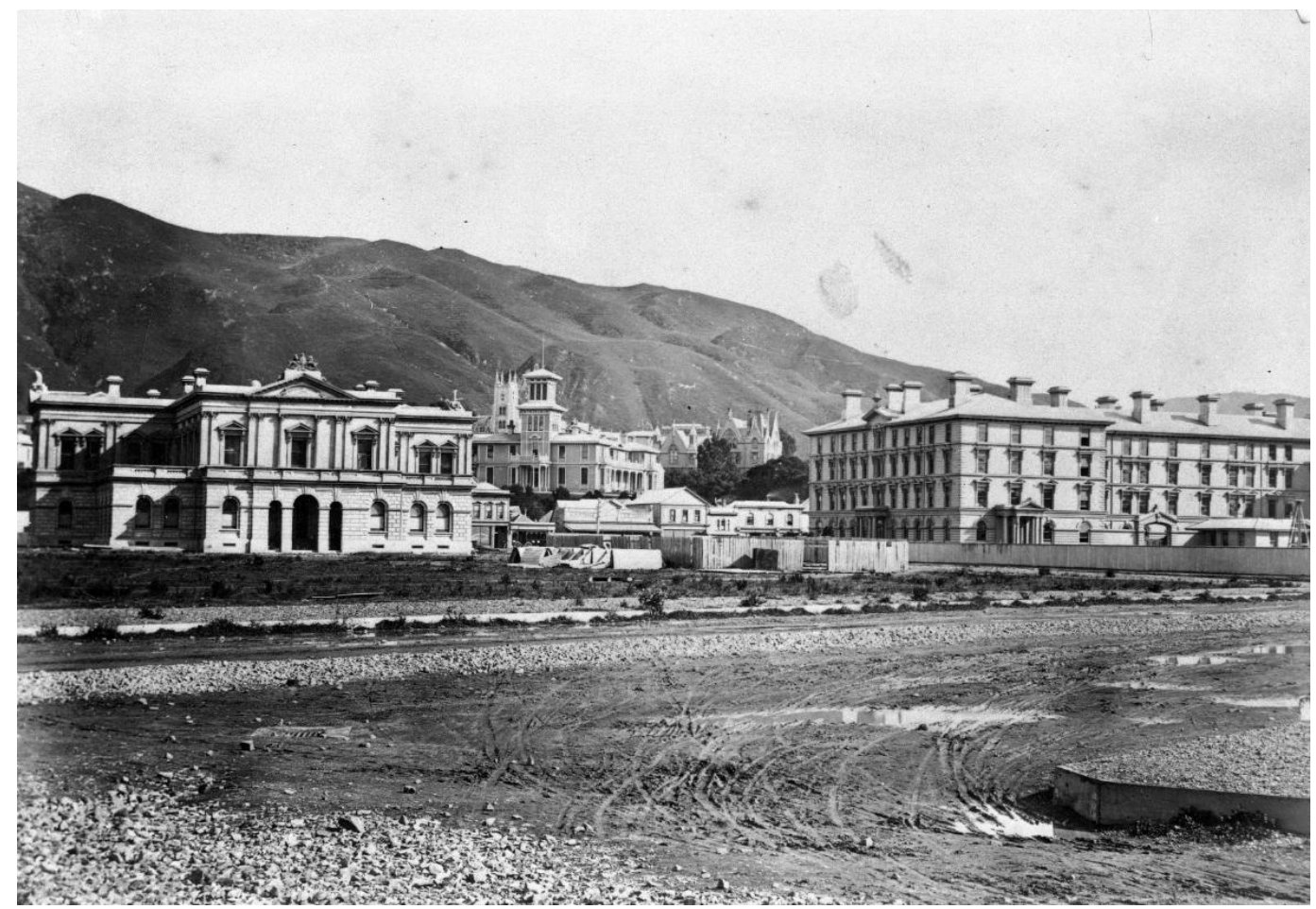

Ill. 65 OHCB (left) viewed from Thordon reclamation (c. 1881)

that the later additions disturbed the strict symmetry of the original. ${ }^{178}$ Alterations within the building were far more numerous. The Supreme Court Conservation Report notes over 100 extant renovation drawings dating up to the 1970s, including the flooring over of two double

178 Wilson, et al., "Natural Justice," 54. See Appendix 3. 
height spaces, the rebuilding of stairs, the reconfiguration of offices, and the lowering of ceilings, all in styles generally contemporaneous with their periods of construction: ${ }^{179}$

One of the challenges of the conservation of the building was how to treat these alterations. Some changes were deeply integrated into the fabric of the building and had been made very early in its life, while other had quite distinct historic and aesthetic values of their own. Examples of the latter are the upgrading of the Chief Justice's chambers in the 1950s, which saw the moulded Victorian finishes replaced with flush mahogany fittings and steel-framed windows, and the modernisation of Courtroom 3, where plywood, broad flush architraves, and a stark red and black panelled ceiling are evocative of the work of the 1960s. ${ }^{180}$

As part of the Option C (Modified) brief for the Supreme Court project, the OHCB was painstakingly restored in accordance with the recommendations of the Supreme Court Conservation Report. The 1981, 1913, and part of the 1907 additions to the northwest of the building were demolished to make way for the Supreme Court, although windows, doors and mouldings were salvaged where possible. ${ }^{181}$ By comparison with the Supreme Court, the OHCB's material palette and detailing seem sumptuous by modern standards. Heart matai tongue and groove flooring, kauri and rimu exterior and interior joinery and panelling, ornate plaster mouldings, carved timber friezes and patterned carpets are found throughout (Ill. 60). Some technologies were significantly updated in the restoration process, such as heating and ventilation systems and the introduction of insulated window units. Spaces renovated during the original life of the building were largely retained and restored consistent with their period, for example the (original) Chief Justice's chambers with its 1940s style mahogany joinery

\footnotetext{
${ }^{179}$ Cochran

180 Wilson, et al., "Natural Justice," 54.

${ }^{181}$ See Appendix III - Supreme Court Conservation Report (excerpts)
} 
(Ill. 67). All these elements were carefully restored by skilled artisans, many of whom relearned traditional techniques in order to honestly replicate the finishes of the $19^{\text {th }}$ century original. ${ }^{182}$ Even graffiti carved into benches by persons remanded in the basement holding cells and journalists in the No. 1 Courtroom was saved (Ill. 68). Some architectural elements lost over the years of renovation were rediscovered during the OHCB refurbishment. For example, floorlights in the two upper galleries flanking the No. 1 Courtroom shown in the original drawings but no longer evident in the building were restored (Ill. 69), and original ventilation cavities in the masonry walls (possibly an early system of heating) were rediscovered and reused. Given its heritage significance, only one major disturbance to the envelope of the building was made: new openings were cut through two walls of one of the original ground floor judge's chambers to allow the linking of the OHCB with the Supreme Court building (Ill. 70).

Naturally, some significant alterations were made to the OHCB as part of the Supreme Court project. The whole building was base isolated and strengthened to meet modern seismicity regulations, which drew on WaM's experiences gained during the Parliament Refurbishment. ${ }^{183}$ The No. 1 Courtroom was fully restored (and is now once again available for use as a High Court courtroom), replete with original judge's bench and baldacchino; ${ }^{184}$ jury, counsel and press seating; prisoner's dock; fluted cast-iron columns with Corinthian capitals supporting the public gallery; timber wall panelling with carved friezes; and plaster

\footnotetext{
182 Wilson, et al., "Natural Justice," 54.

183 Structural engineering design was undertaken by Holmes Consulting Group Ltd. Their work on the OHCB won them an Institution of Structural Engineers (IStructE) Award in 2010.

184 The baldacchino (the carved timber canopy over the judge's bench decorated with the English Royal Arms (used by New Zealand 1840-1911) and drapes) is thought to have originally been constructed for the 1865 Wellington Supreme Court. Cochran, Supreme Court Conservation Report, 84.
} 
architraves and pediments over doors and windows (Ill. 71). The No. 2 and 3 Courtrooms, however, were modified; the No 2. Courtroom has been converted into the main function room for the Supreme Court complex (Ill. 72) and the No. 3 Courtroom into a similar multifunctional space. This is illustrative of the modern role of the OHCB. While the No. 1 Courtroom has regained some of its original function, the rest of the building now acts in a supporting role to the Supreme Court, providing it with ancillary space for staff and administration, as well housing the Institute of Judicial Studies, the professional development arm of the New Zealand judiciary.

Just as the laying of the Supreme Court foundation stone on 1 December 1879 had been a significant public event, ${ }^{185}$ so too was the opening of the new Supreme Court on 18 January 2010. The Chief Justice had personally invited Her Majesty Queen Elizabeth II to the opening, who sent in her stead HRH Prince William (Ill. 73). The opening of the Supreme Court complex marked a significant milestone in the history of New Zealand's judicial architecture, with the rejuvenation of a building illustrative of 130 years of post-Treaty of Waitangi judicial history and the commissioning of one expressing the present and future of New Zealand's judicial system.

185 Some 2000 people attended the laying of the OHCB foundation stone, an event which involved a great deal of Masonic pomp and ceremony. 


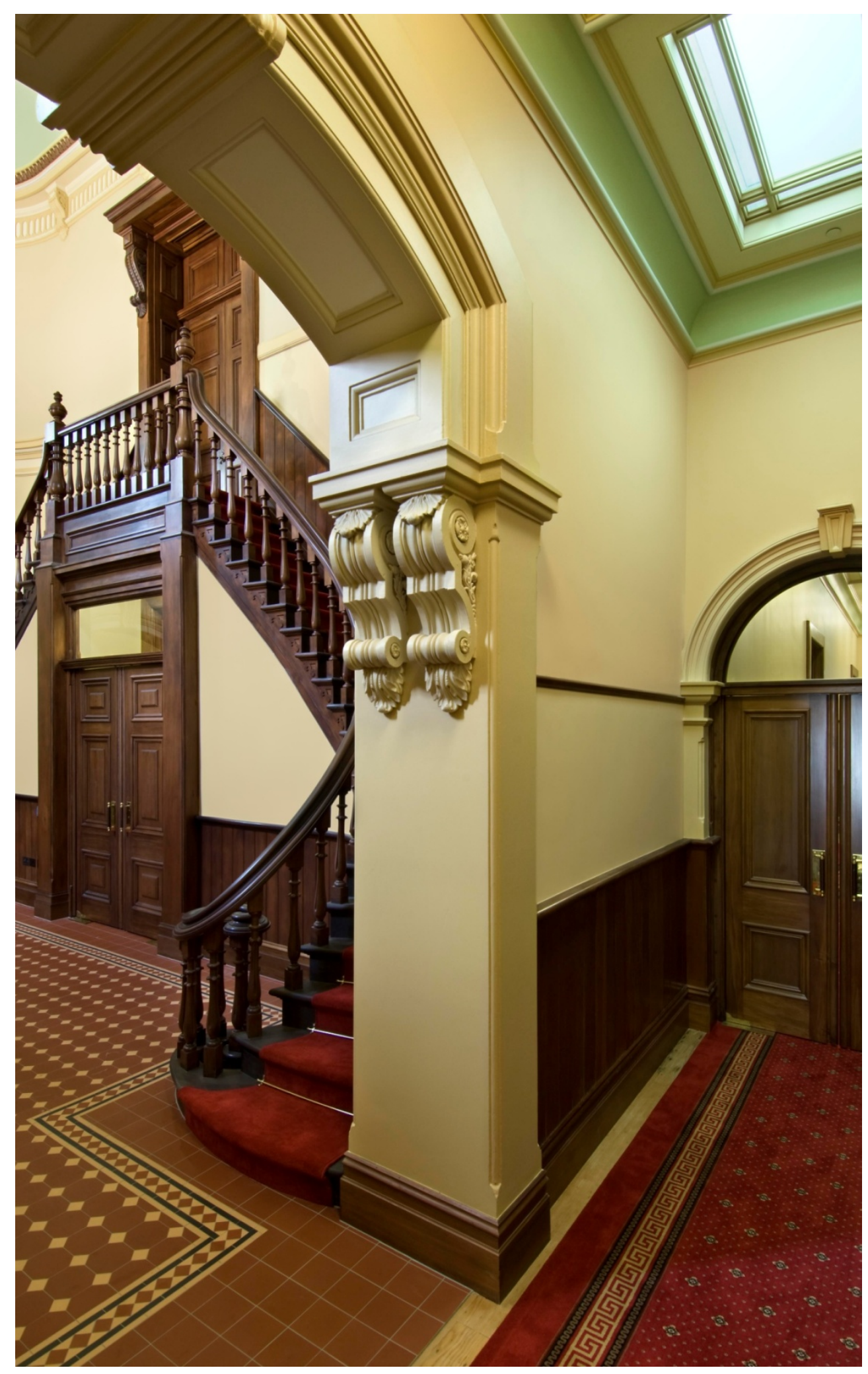

Ill. 66 OHCB lobby (entrance to No. 1 Courtroom on left) 


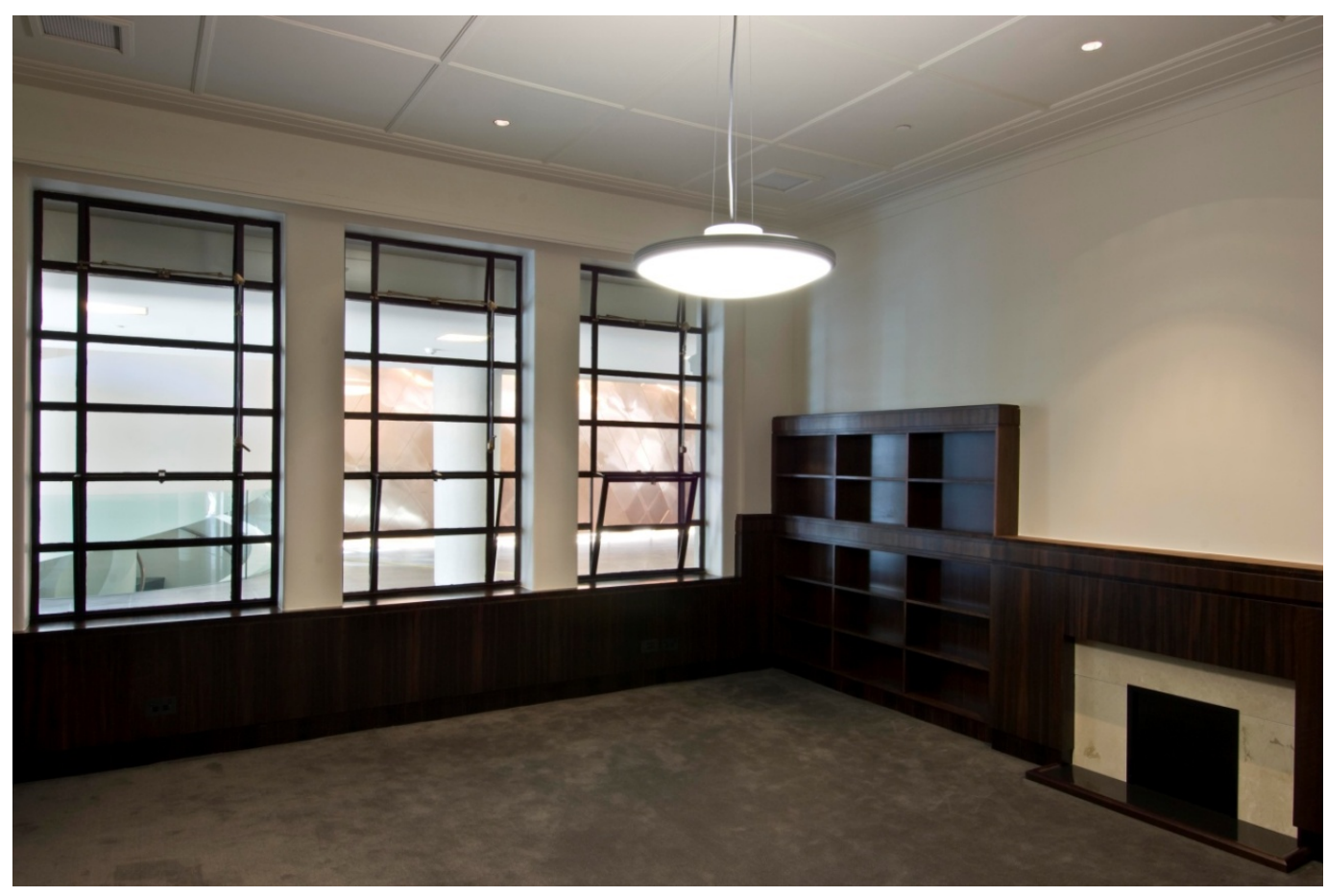

Ill. 67 Former Chief Justice's chamber, OHCB

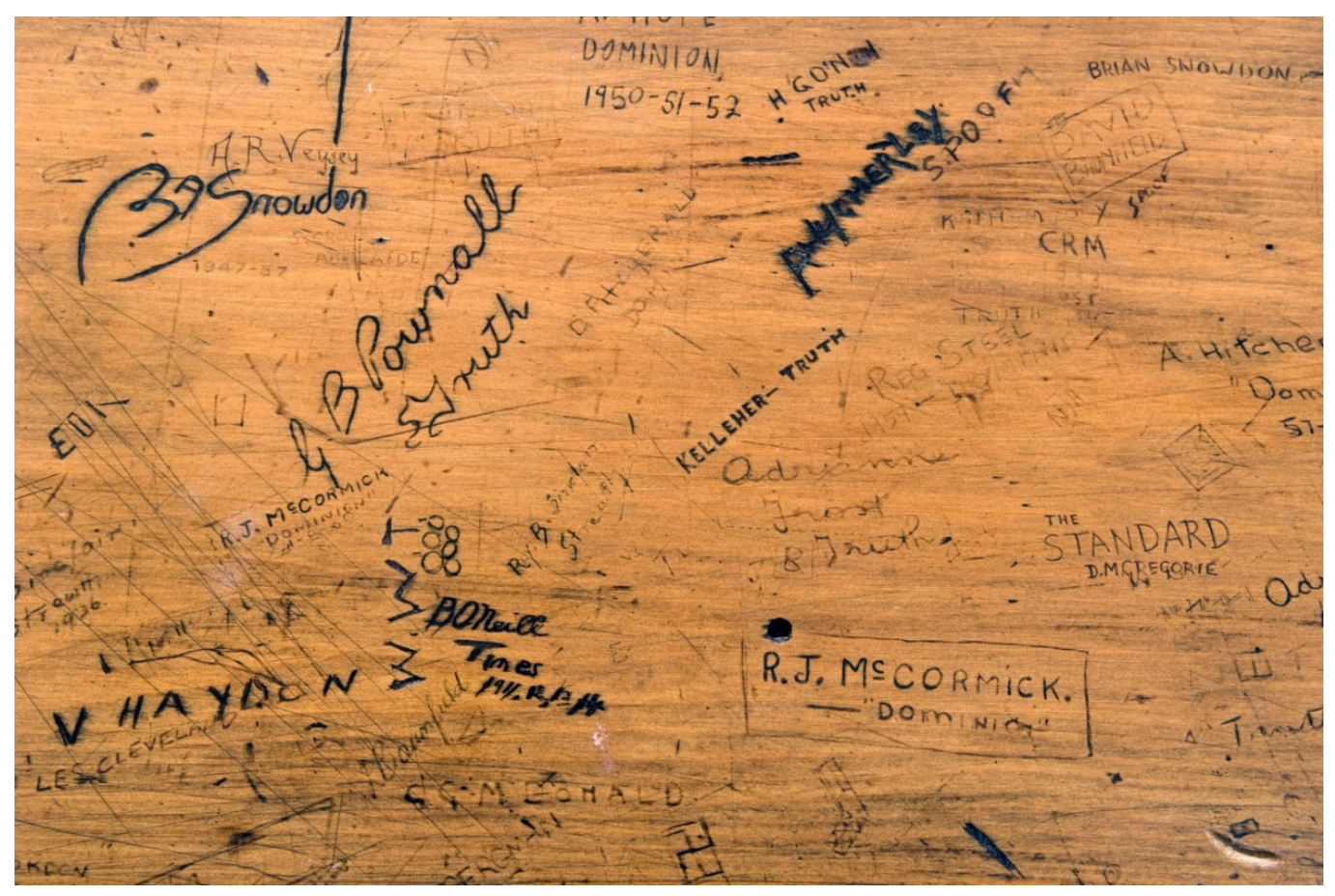

Ill. 68 Graffiti on press desk, No. 1 Courtroom, OHCB 


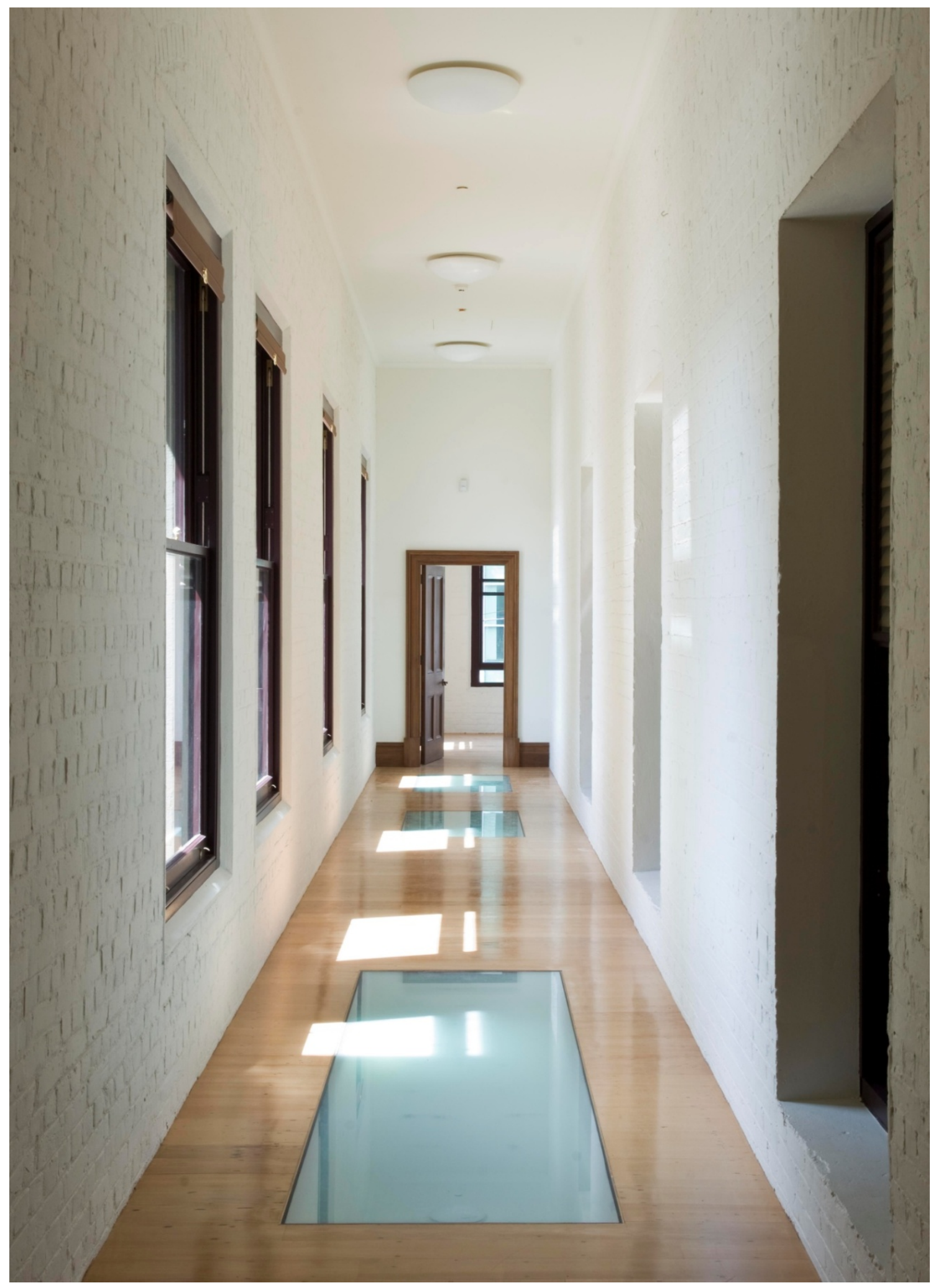

Ill. 69 Floor lights surrounding No. 1 Courtroom, OHCB 


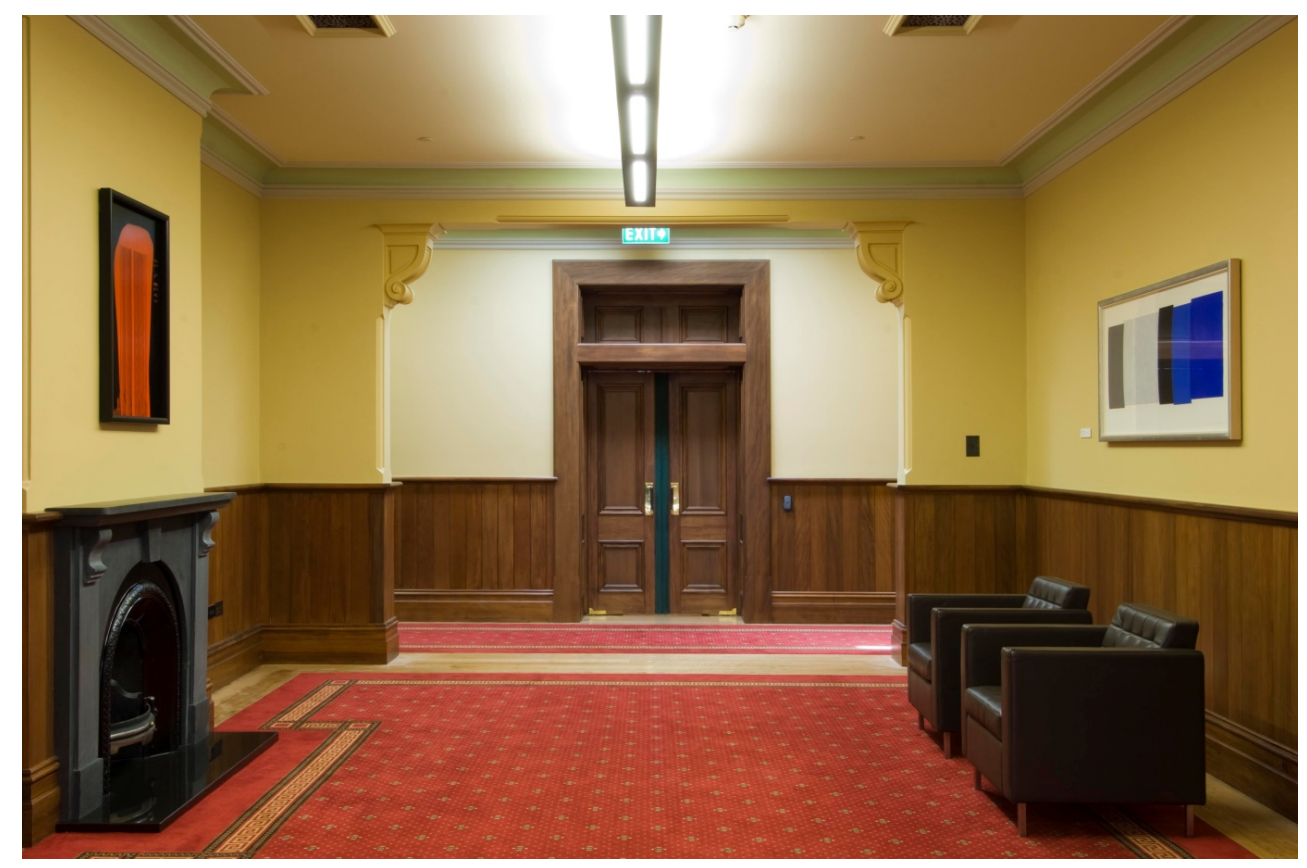

IIl. 70 Link between Supreme Court and OHCB, view from Supreme Court

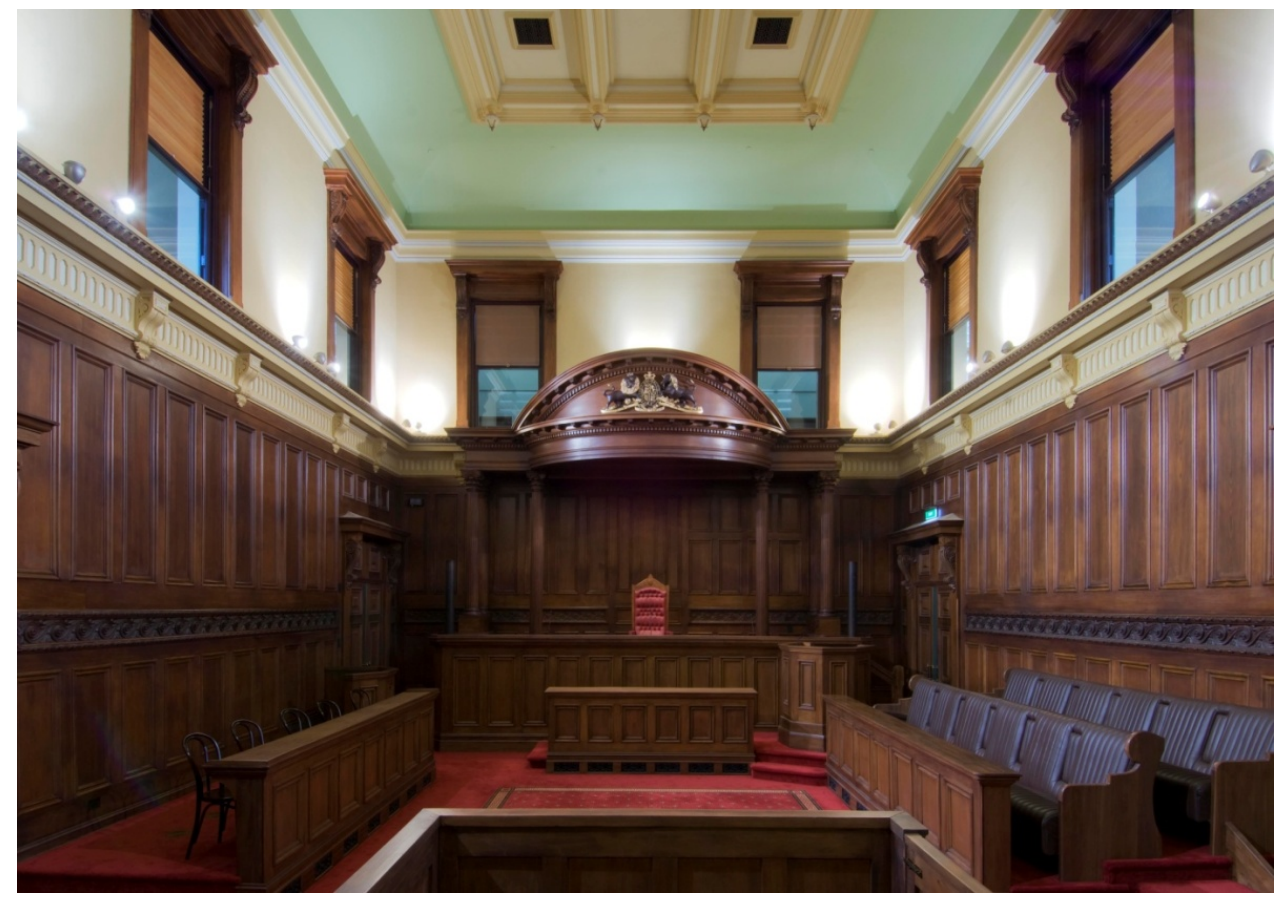

Ill. 71 No. 1 Courtroom, OHCB 


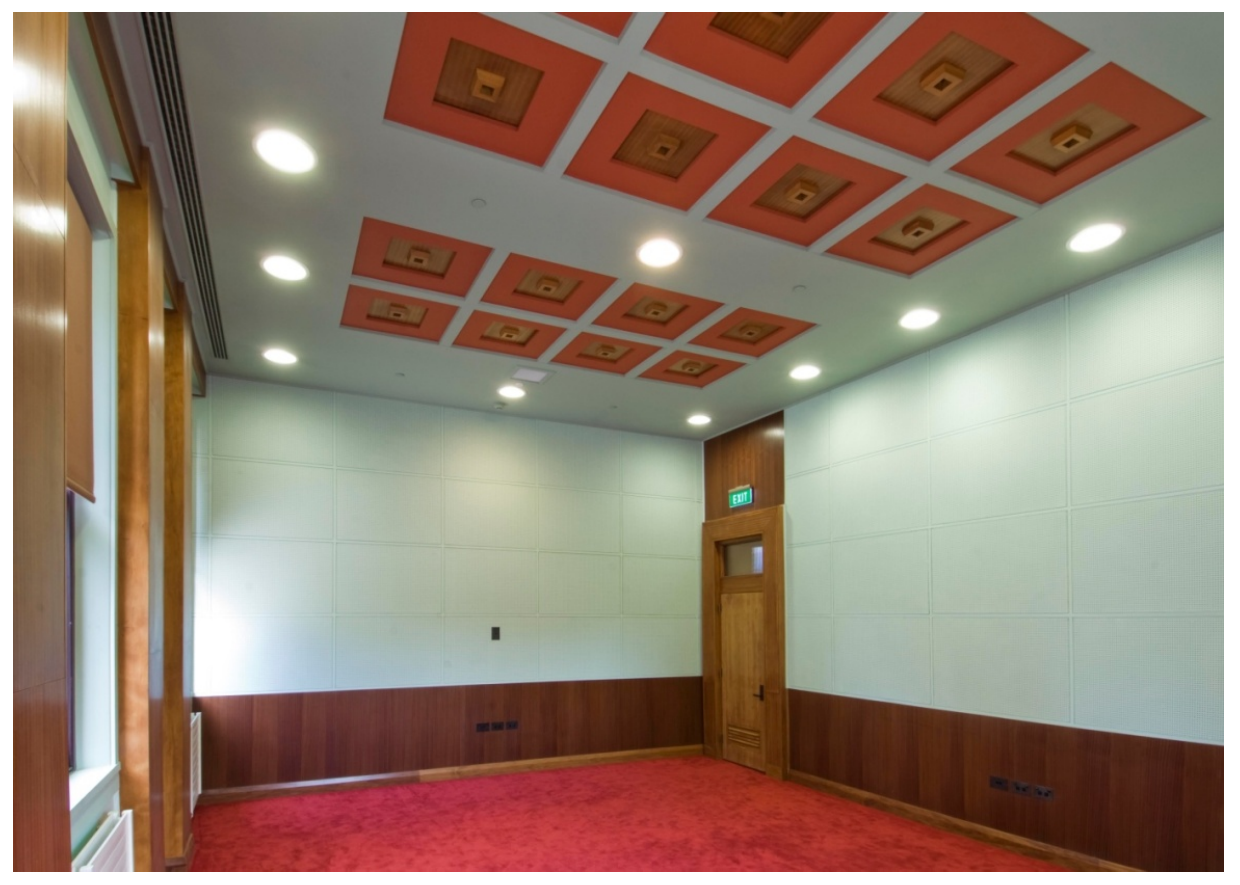

Ill. 72 No. 2 Courtroom, OHCB

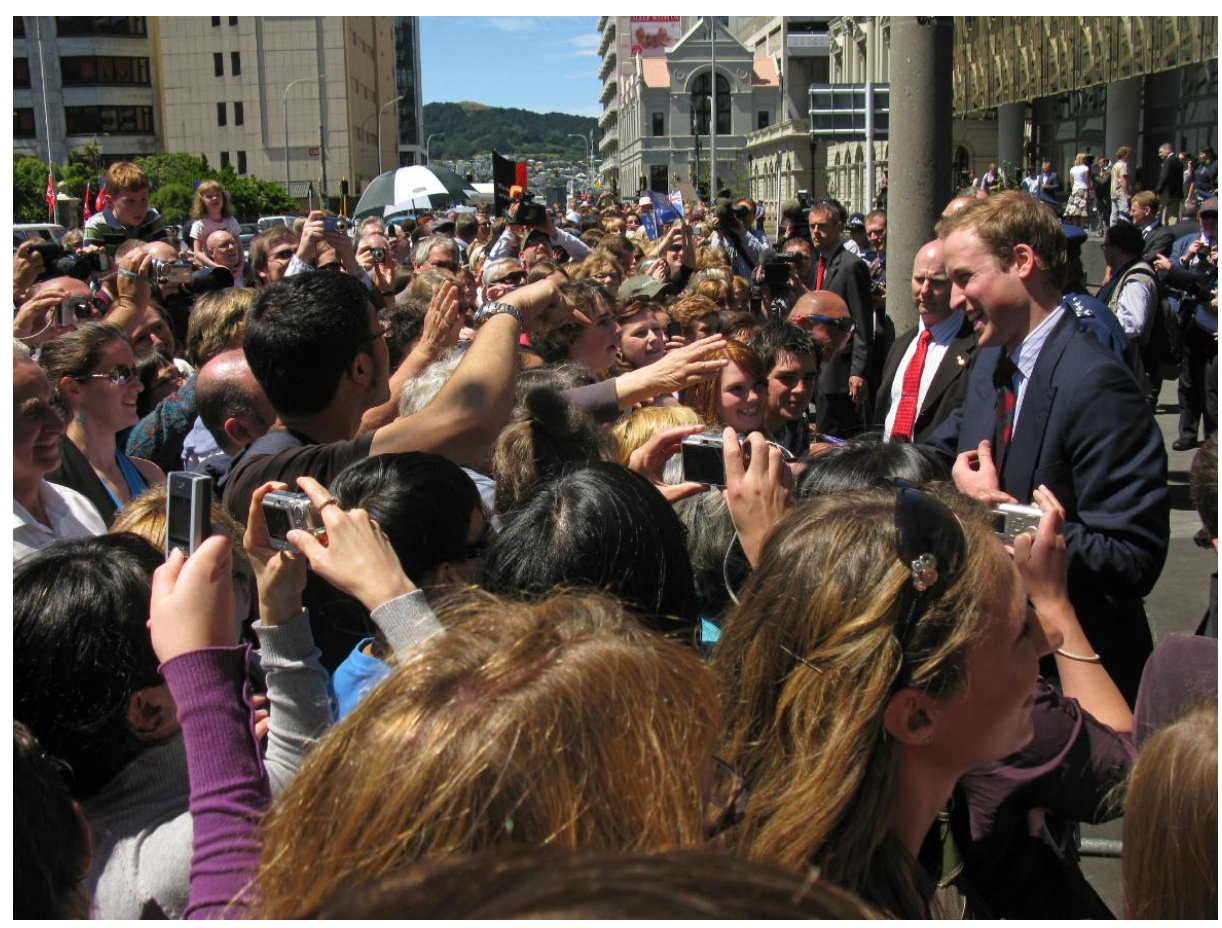

Ill. 73 HRH Prince William opening the New Zealand Supreme Court, 18 January 2010 


\section{Summary}

The Supreme Court project brief challenged architects Warren and Mahoney with the unusual juxtaposition of having to work with a significant heritage building with tight restrictions on adaptation and re-use, and a substantially open field of play in terms of appearance of the new courthouse. Asked to design a Supreme Court that befitted the stature of the institution without being ostentatious, WaM adopted an approach that completely restored the OHCB, thus giving it a renewed life expectancy, and used the model of the former Supreme Court to inform the new. Taking the single Supreme Court courtroom as their starting point, the architects took their cues as to the scale and rhythm, materials and planning of the Supreme Court from the OHCB. Thus the architecture of the Supreme Court relates with respect and cohesion to the OHCB, yet represents a fresh consideration of the traditional courthouse typology, one that signals the nature of the administration of justice in New Zealand today, and into the future. The architectural embodiment of that nature - the aspirations of the judicial system - in the Supreme Court complex's architecture is the subject of detailed assessment in Chapter VI, Representing Justice. 


\section{Representing Justice}

Regarding the value of civic spaces, Richard Francis-Jones of the Australian architecture firm Francis-Jones Morehen Thorp has said that "the most important thing is you somehow have to create a structure that embodies the social values of the time. The buildings need to capture a spirit of the select group of people involved to capture their aspirations."186 This is certainly true of the New Zealand Supreme Court. Chapter VI of this thesis assesses the success of the Supreme Court complex as an embodiment of judicial aspirations. Armed with theoretical perspectives on the role judicial architecture plays in communicating judicial aspirations, knowledge of the Supreme Court's judicial aspirations expressed in the Court's legislation and briefing process, and an understanding of the complex's built form, this Chapter refocuses attention on the assumption stated at the outset of this study, namely, that the architecture of the Supreme Court complex legibly responds to its briefing process and, in doing so, expresses the aspirations of the New Zealand justice system at the beginning of the $21^{\text {st }}$ century. Based on the judicial aspirations of the Supreme Court identified in Chapter IV, this assessment is made under three thematic headings:

1) Heritage and Independence, which draws on theories of the role of heritage conservation in identity formation to assess architectural expressions of concepts of judicial independence within the context of New Zealand's legal history and traditions;

${ }^{186}$ Nicola Harvey, “Art World” Mindfood (Apr 2010), 61. 
2) An Indigenous Court, which draws on theories of cohesive and differentiating symbolic gestures and of landscape as symbol of national identity to consider how the Supreme Court complex expresses the indigeneity of its condition; and

3) The Rule of Law and Parliamentary Sovereignty, which assesses notions of "openness" of the Supreme Court institution such as access and transparency that are expressed in the Court's architecture, and architectural design moves in the Supreme Court complex that reinforce the tenet of Parliamentary sovereignty within New Zealand's constitutional framework.

Unlike previous chapters, the key findings of Chapter VI will not be summarised at the end of this section, but rather formal conclusions will be made in the closing chapter.

\section{Heritage and Independence}

The section 3(1)(a)(i) purpose of the Supreme Court recognises that a unique legal system has evolved in New Zealand while also recognising the role New Zealand's colonial heritage and legal traditions have played in that evolution. It is suggested that an identifiable Supreme Court building expresses the Court's independence from its colonial umbilicus, while the restoration and incorporation of the $\mathrm{OHCB}$ is an important and appropriate counterpoint within the Supreme Court complex, recalling the centuries-old legal and architectural heritage from which the Supreme Court evolved. This section assesses questions of continuity and change in the Supreme Court architecture: does the design of the Supreme Court represent a radical shift in New Zealand judicial architecture or simply a reformulation of the status quo? What does any such shift or reformulation tell us about the nature of the judicial system in New Zealand? 
As described in Chapter II, New Zealand's judicial system (including its architecture) is predominantly English in heritage. As previously discussed, architectural styles imported from England informed New Zealand's judicial architecture into the 1930s, after which time more international influences of Art Deco and Modernism became incorporated. A relatively young country with few extant examples of built heritage, attachment to heritage buildings is strong in New Zealand and many former (and current) courthouses have NZHPT registration. As noted earlier, limitations on reconfiguration permitted under the OHCB's heritage protections meant that the Justice Park site between the OHCB and Lambton Quay was adopted as the site of the new Supreme Court. Adding the Supreme Court to the OHCB became a fitting opportunity (viewed at least through the lens of this research) to architecturally explore juxtapositions relating to history/tradition and future/innovation in judicial architecture. It is useful at this stage, therefore, to consider in general terms the value retaining the OHCB as part of the Supreme Court complex had in terms of heritage and identity.

One important point raised in the Supreme Court Conservation Report was that the OHCB provided a continuous link with the administration of justice in New Zealand over 130 years. 187 The Supreme Court architects retained the historic fabric, renovating and innovating as they went to include contemporary environmental engineering systems while retaining important features from not only the 1800s, but also the 1940s, 1960s and 1990s. As noted in Chapter V, the only major exceptions to the generally conservationist approach were the

187 Cochran, Supreme Court Conservation Report, 66. 
linking of the two buildings and the collateral removal of the 1981 extension (which was in any event not considered to have any heritage significance). ${ }^{188}$

Restoring the OHCB was more significant in this context than simply renovating an old building. A significant corollary of restoring the OHCB was that it anchored the Supreme Court within a recognisable context and heritage. As Howard notes:
a major outcome of conserving and interpreting heritage, whether intended or not, is to provide identity [...]. There may be other purposes as well, such as legitimation, cultural capital and sheer monetary value, but the common purpose is to make some people feel better, more rooted and more secure. ${ }^{189}$

This grounding of the Supreme Court was important for the founding of a new legal tradition in New Zealand. There had been significant concern from some sectors of the legal and business communities that the new Supreme Court would lead to an era of judicial activism by a bench that felt unfettered by the past. However, as the Chief Justice said:

\footnotetext{
The reference to New Zealand's history and traditions in the statute does not prompt any wholesale reassessment of our law. The history and traditions of the [English] common law are our history and traditions. So too are the great charters of England, such as the Magna Carta. In its origin, this history and tradition predates European knowledge of New Zealand by centuries. To that extent it is an inherited tradition. But to a substantial extent English law is not inherited history but part of our own direct history. ${ }^{190}$
}

\footnotetext{
188 Ibid., 130.

189 Peter Howard, Heritage: Management, Interpretation, Identity (London: Continuum, 2003), 147.

190 Sian Elias, "Supreme Court Special Sitting Speech."
} 
The OHCB is emblematic of the direct history of the Supreme Court to which the Chief Justice refers, but this grounding within the traditional judicial architecture typology goes further than simply having the $\mathrm{OHCB}$ to hand as a reference point. For all that at first glance appears divergent between the OHCB and the Supreme Court, a remarkable amount of the latter remains consistent with the $19^{\text {th }}$ century courthouse typology. Were he to be revived to the $21^{\text {st }}$ century, Chief Justice Prendergast (who opened the OHCB in 1881) might be startled at the latent effects Modernism has had on judicial architecture, but he would most likely clearly understand the planning and function of the Supreme Court building and courtroom due to these consistencies.

As noted in Chapter IV, the design brief stipulated entry to the Supreme Court from Lambton Quay. Given that this entrance would be diametrically opposed to the entrance to the OHCB on Stout Street, it made sense for the architects to employ the axial planning of the OHCB in the Supreme Court building. ${ }^{191}$ The entry to the Supreme Court further mirrors that of the OHCB with its air lock for security and to protect from inclement Wellington weather. Primacy is clearly given to the central courtroom in each building with supporting spaces surrounding. There is a clear relationship between the materials employed in the two courthouses. The rendered masonry and rich native timbers of the OHCB are echoed in the basalt, concrete and pale beech of the Supreme Court. Both have New Zealand wool carpets, and glazing for daylight and view features in both, albeit that the proportion of glazing to volume in the Supreme Court would have been technically impossible when Burrows designed the OHCB.

191 See Appendix IV - Supreme Court - Architectural Drawings. 
Even the copper roofing of the OHCB finds its relations in the copper roofing and bronze screen of the Supreme Court (Ill. 74). The basis for the planning of the two courthouses is as near to identical as possible with arrangements of courtrooms surrounded by offices and ancillary spaces. Externally, the scale of the Supreme Court is intentionally sympathetic to the OCHB; the rhythm of the classical proportions of the OHCB informs the fenestration and rhythm of the $\mathrm{p}$ hutukawa/r $\mathrm{t}$ screen. It is suggested that this symmetrical connecting with the past is significant as it suggests order, stability, and permanence in the new Court. ${ }^{192}$

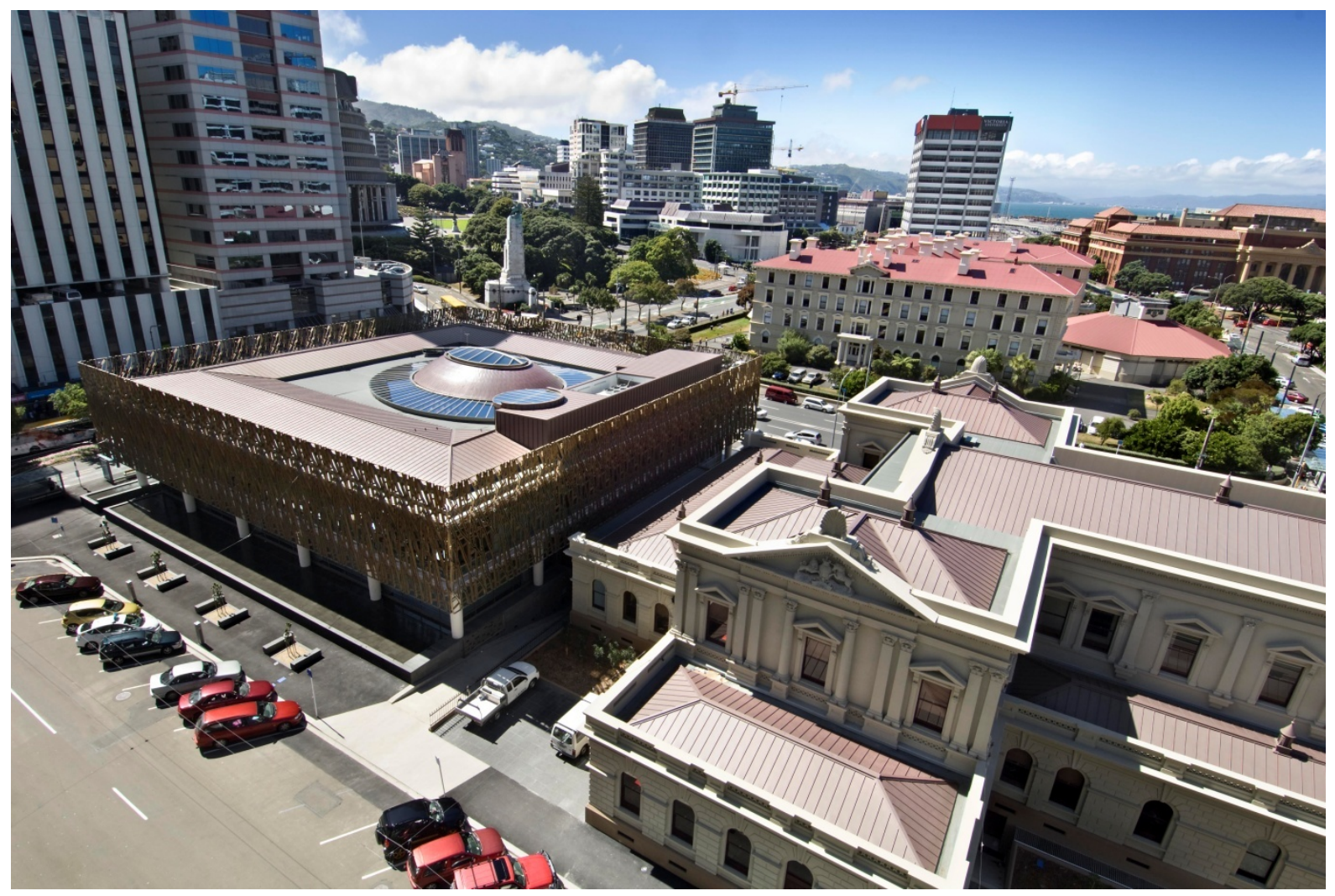

Ill. 74 Supreme Court complex from above

192 Cf. René Smeets, Signs, Symbols and Ornaments (New York: Van Nostrand Reinhold, 1973) and Rudolf Arnheim, The Dynamics of Architectural Form (Berkeley: University of California Press, 1977). 
In the midst of all this intentional consistency with the past, what is there to give the public confidence that the Supreme Court is also concerned with the future of New Zealand's justice system? The most appreciable aspect of the Supreme Court that evinces the future of the administration of justice in New Zealand is the form of the courtroom. The ovoid form of the courtroom is highly innovative in the New Zealand context and internationally. Comparisons have been drawn between the New Zealand Supreme Court and the Bordeaux Law Courts (1998), which also have exposed, rounded courtrooms. ${ }^{193}$ However, the planning of the courts' interiors is orthogonal in the Bordeaux scheme and much more akin to the OHCB than the Supreme Court (Ill. 75-77). Drawing on Arnheim, Goodsell suggests that a rounded form gives users a greater sense of personal significance:

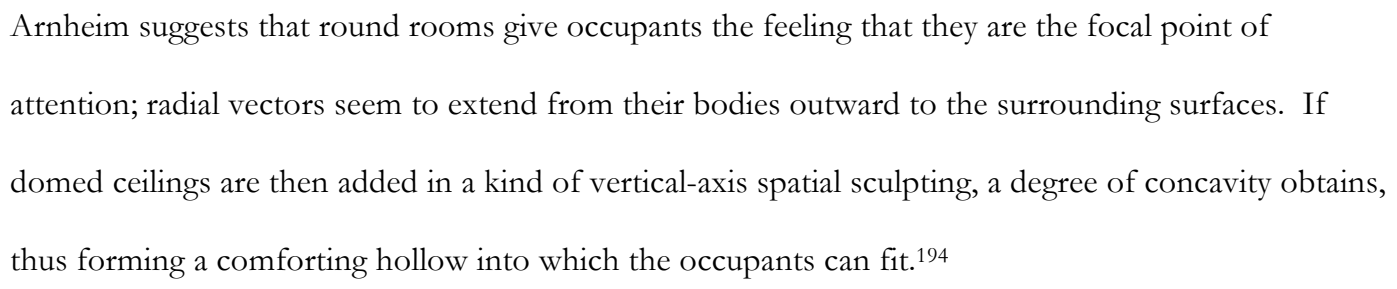

While the form of the courtroom was primarily driven by the judges' requirement for a curved bench, any psychological effect of the architectural outcome, while unintentional, should not be discounted.

\footnotetext{
193 The Bordeaux Law Courts designed by Richard Rogers Partnership (1998) were a precedent studied in relation to the Supreme Court project. Other precedents investigated included the High Court of Australia and the Singapore Supreme Court. Wilson, discussion; Hampton/Jeppesen, discussion.

${ }^{194}$ Goodsell, The Social Meaning of Civic Space, p. 37, citing Arnheim, op. cit..
} 


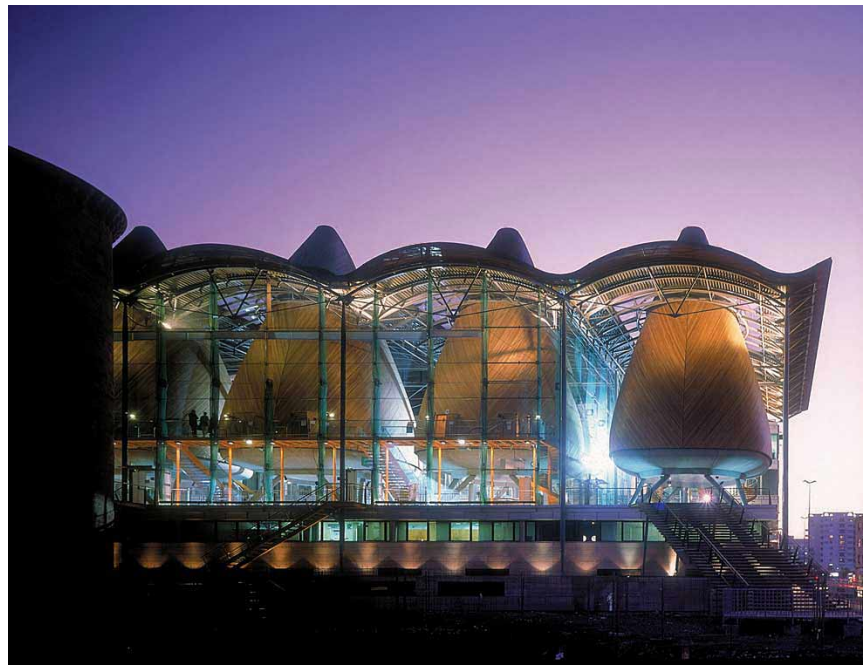

Ill. 75 Bordeaux Law Courts

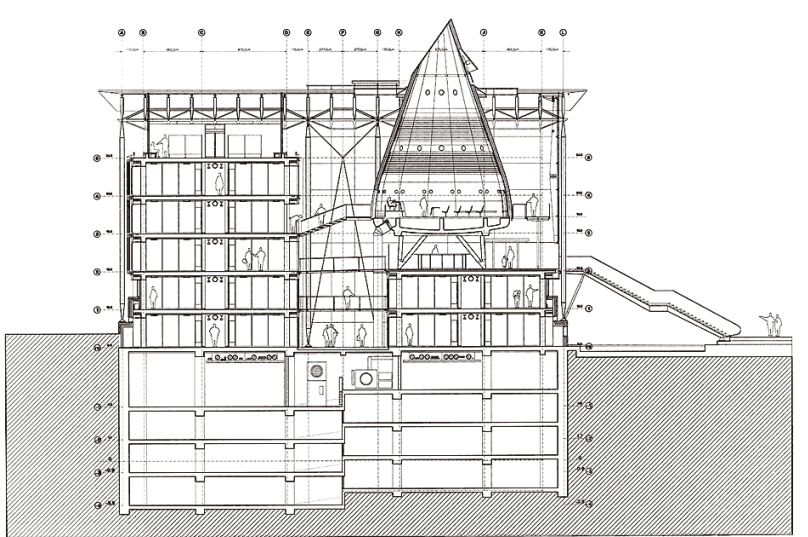

Ill. 76 Bordeaux Law Courts (transverse section)

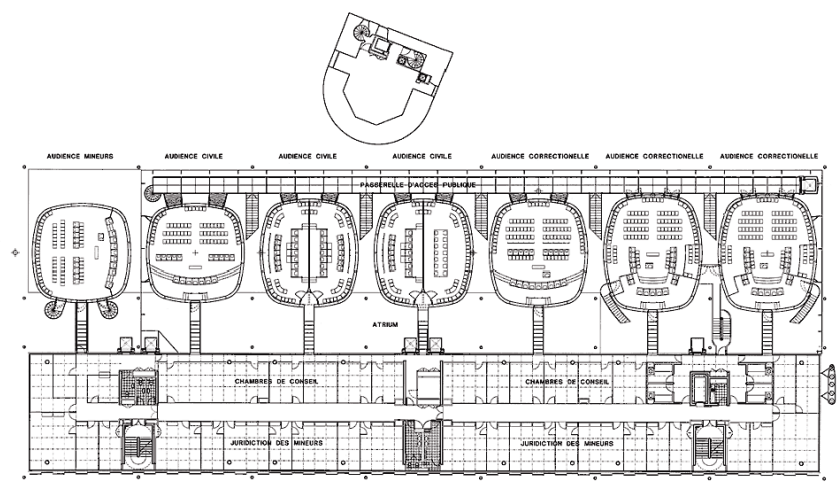

Ill. 77 Bordeaux Law Courts (plan) 
The Supreme Court has a very different gravitas to it compared with the OHCB. What might now been seen as the opulence and stuffiness of the restored OHCB No. 1

Courtroom (which was, in its day, seen as only appropriate for the status of the Court and its judges) has given way to a perceptibly more relaxed atmosphere, of which the reduced elevation of the bench compared with the traditional courtroom and more inclusive in-theround form is symptomatic. The differences between the OHCB and Supreme Court in this respect reflect that the judicial system has greatly relaxed its formality since the late $19^{\text {th }}$ century, for example, full court dress is now restricted to ceremonial occasions (Ill. 78 ), there is a conscious effort to use "plain English" language in the Court, and a much more collegial work environment was desired by the judges.

It is suggested that the materiality of the Supreme Court courtroom supports this view. ${ }^{195}$ Further, the modern administration of justice requires the incorporation of technology like never before, and this is certainly true in the Supreme Court, but the careful incorporation of technology so that it assists and facilitates but does not distract from or impede judicial proceedings. ${ }^{196}$ The new courthouse has functional requirements that have tested the architects' precision of design and innovation. Indeed functional requirements give it much of its impact - it was acoustic performance which necessitated the faceted cone-like interior. There can be no doubt that the new courtroom is a significant development of (rather than a departure from) the traditional typology. All said and done, it is clear that the Supreme Court building has as its direct architectural ancestor the OHCB (and thus the antecedents to

195 In The Language of Post-Modern Architecture, Charles Jencks suggests that "dark-stained wood suggest formality while light-stained or natural wood speaks of informality”. See Charles Jencks, The Language of Post-Modern Architecture (New York: Rizzoli, 1977), 131.

196 This was a requirement of the judges. Wilson, discussion. 
the OHCB in English judicial architecture). This clear relationship grounds and reinforces the identity of the Supreme Court within (and as symbol of) the New Zealand judicial system. Just whose identity is reinforced remains uncertain however.

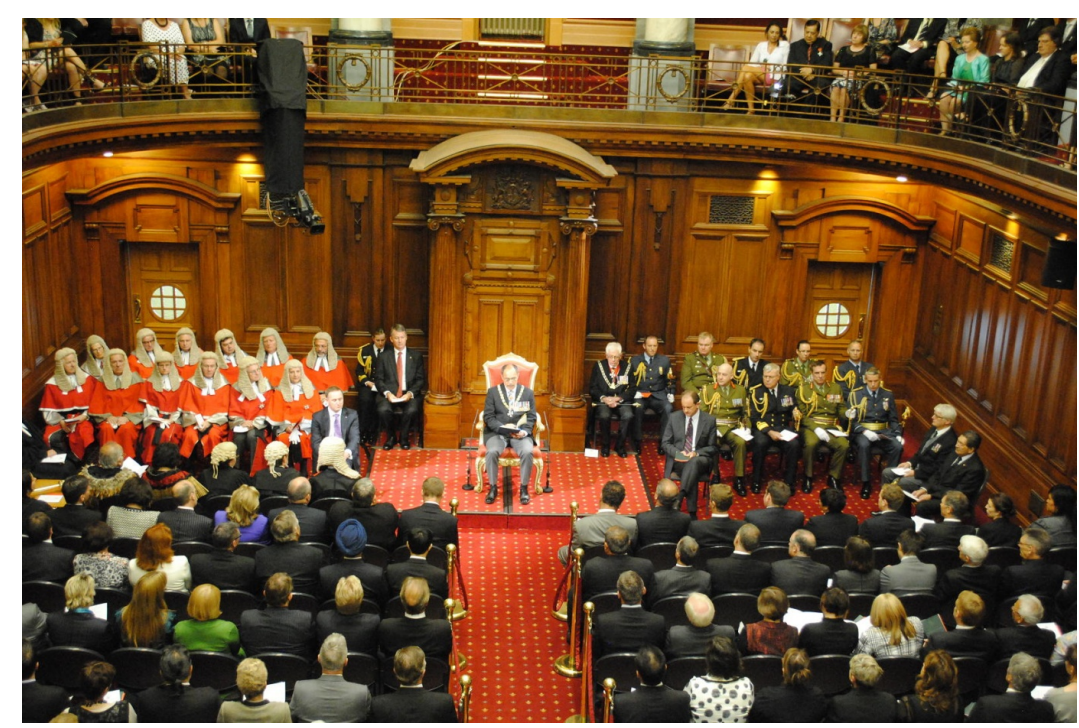

Ill. 78 Senior members of the judiciary (in red gowns) attend the opening of Parliament

Trapeznik \& McLean have observed that a sense of collective identity incorporating commonly agreed-upon cultural values enables us to speak of "our" or "national" heritage. ${ }^{197}$ In her speech at the opening of the Supreme Court building, the Chief Justice noted that New Zealand's legal traditions date back many centuries, but recognised that:

$[\mathrm{I}] \mathrm{n}$ these islands we have other traditions. Some were shaped by our history as a country already occupied by M ori. [...]. English law adapted to meet those local conditions. [...]. Other traditions arose from the experiences of our young country. [...]. All of these strands of history and memory

\footnotetext{
197 Alexander Trapeznik \& Gavin McLean, "Public History, Heritage and Place" in Alexander Trapeznik (ed.) Common Ground? Heritage and Public Places in New Zealand (Dunedin: University of Otago Press, 2000), 13-24, 15.
} 
contribute to a distinctive New Zealand legal tradition. The Supreme Court is set up to operate consciously within it, not to tear it down. ${ }^{198}$

A key symbol of the dual heritages and traditions of New Zealand's judicial systems is the side-by-side display of the Queen Anne inkwell and waka huia in front of the Supreme Court bench:

Her Majesty has shown interest in the Court from its creation. Then she sent us a magnificent silver inkwell, part of the Royal Treasury. Two such inkwells are placed before the Judges of the Privy Council whenever they sit to advise the Monarch on petitions for justice, as they did on appeals from New Zealand for 165 years. The display of the inkwell in this new courtroom symbolises links that endure and a heritage of which we are proud. [...] In this courtroom the Queen's inkwell is matched with a beautiful waka huia kindly lent to us by Te Papa. The waka huia is thought to date from the same time as the inkwell which, by British reckoning, is from the reign of Queen Anne. It is likely that the tangata whenua of this region, Te Atiawa, whose taonga it is, would date the waka huia in some other way since the first British monarch of whom they became aware was George III. The two taonga represent the two strands of our original heritage. ${ }^{199}$

The display of the inkwell and waka huia is understatedly significant. One need only refer to the British Royal Arms that hangs above the bench in the OHCB No. 1 Courtroom to sense how far New Zealand jurisprudence has come since 1881 (Ill. 79). That said, it is suggested that the Supreme Court complex nevertheless ignores a perspective of the heritage and traditions of the Court that might take cognisance of a pluralist history of the institution, particularly one which recognises the impacts on $\mathrm{M}$ ori the workings of the judicial system has had since 1840.

\footnotetext{
198 Sian Elias, "Supreme Court Special Sitting Speech."

199 Sian Elias, ““'Supreme Court Opening Speech.”
} 


\section{As Trapeznik \& McLean observe:}

$[\mathrm{T}]$ he heritage sector has been slow to embrace the concept of pluralism. Indeed, heritage advocates most frequently adopt a Pollyanna-like attitude to the collective symbols of the past. They rarely portray heritage as being about alienation. Instead, they talk about pride and community cohesion, spinning tales of success, not failure. In doing so, they increasingly market heritage as a commodity, producing a past that did not exist in order to promote the interests of the tourist industry, property developers, the keepers of public culture and the promoters of national identity. [...] Just like the artfully staged photographs of buildings in some coffee table books, heritage often implies a past bereft of people, their ideas, or their struggles. ${ }^{200}$

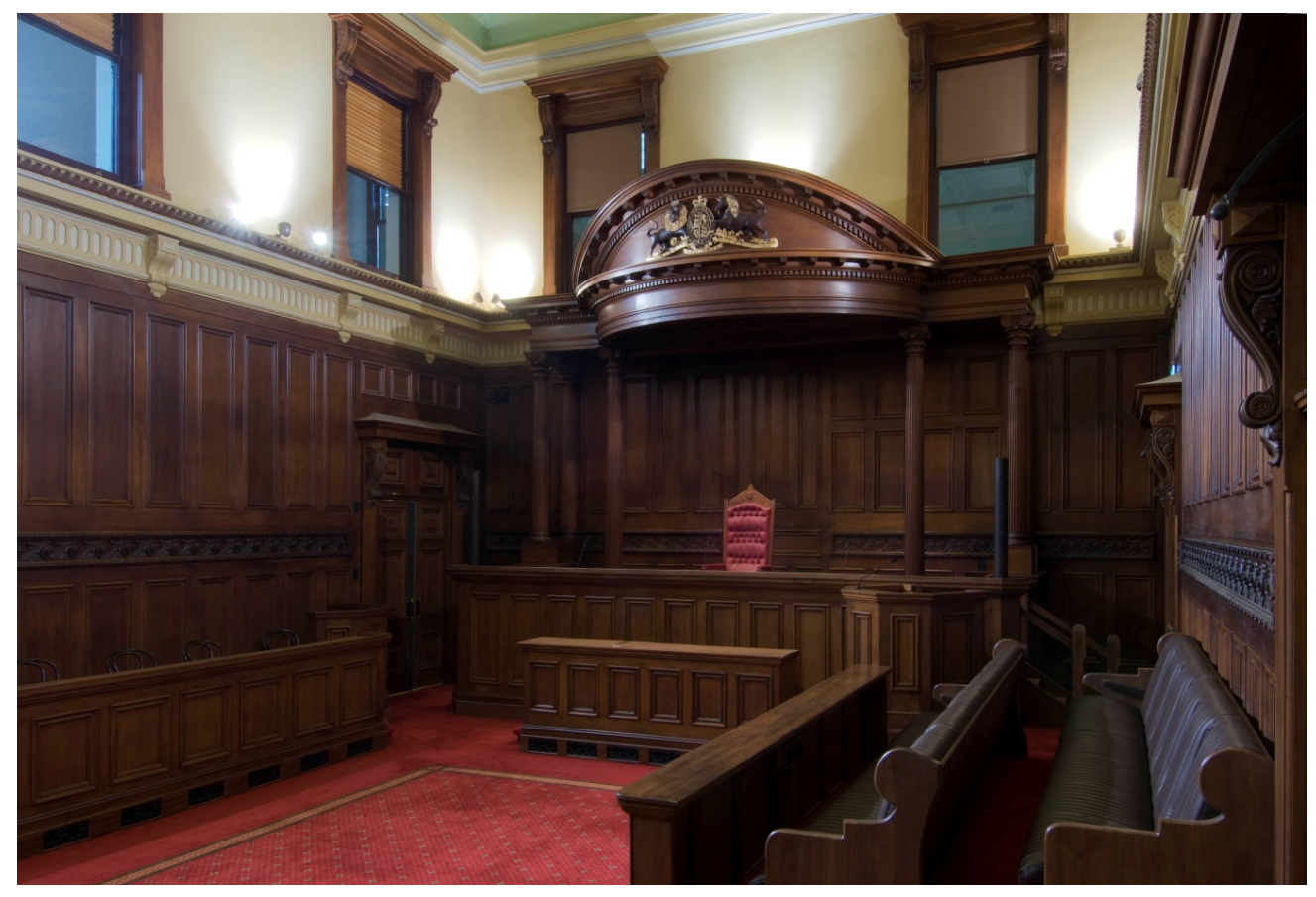

Ill. 79 Baldacchino with British Royal Arms, No. 1 Courtroom, OHCB

200 Trapeznik \& McLean, "Public History," 15. It is positive to note, however, that the evolution of the building and traces of human presence have mostly been retained, for example, in preferences in office fit out from the 1940s and 1960s, graffiti in the OCHB holding cells, and the Lord Cooke library collection. However, it is notable that the copper exterior of the courtroom, a potentially rich palimpsest of human presence in the Supreme Court, has, since opening, been coated with a mark-resistant coating in order that fingerprints (and other marks) be easily removed, although to date no "Do Not Touch" sign has been placed in the lobby. 
Care must be taken, however, not to be historically relativistic in this regard. Rather than reading the Supreme Court complex as ignorant of the multiple strands of influence on the judicial system various communities have provided, one might observe that the history of the Court and judicial system has, in fact, been predominantly monocultural, and that the restoration of the OHCB vis-à-vis the Supreme Court stands an apt testament to that condition. This should not, however, excuse an intentional ignorance of that condition. If it is to be accepted that the Supreme Court's architecture expresses the independence of the institution within the context of its heritage and traditions (which this study does), then the question must be asked: As the highest court in the land, what does the Supreme Court building say about the "New Zealand-ness" of the judicial system at the beginning of the $21^{\text {st }}$ century? This is the focus of the next section, An Indigenous Court.

\section{An Indigenous Court}

One of the key institutional purposes of the Supreme Court is to establish an indigenous court of final appeal, one that administers justice with a recognition, understanding and application of New Zealand's unique jurisprudential conditions. This purpose begs a number of questions: What about the Supreme Court building speaks of the indigeneity of its situation? What does it say about the "New Zealand-ness" of doing justice in this country? What is included in that conceptualisation? Perhaps more importantly, what is omitted? There are a number of ways in which the indigeneity of the Supreme Court might have been architecturalised in its building, means most easily summarised in the context of this research as planning, materials, and symbolism. As the preceding discussion revealed, the planning of the Supreme Court represents a minor shift from the status quo of traditional courthouse planning in the common law world. It is suggested that an expression of the indigeneity of 
the Court is not to be found in its planning. The building's materials offer more by way of indigenous expression through the use of native silver beech timber in the interior panelling of the courtroom and the New Zealand basalt stone work of the building's plinth. However, the majority of the materials expressed in the building, while locally sourced insofar as possible, are not uniquely indigenous in nature or use. It is suggested, therefore, that the significant expressions of the indigeneity of the Supreme Court are to be found in the Court building's symbolic devices.

As discussed in Chapter IV, compared with the strict functional requirements it details, the Supreme Court brief is notably unspecific on the issue of how the architecture might express the indigeneity of the Court. As was described in Chapter IV, the brief and its supporting documentation (in all the various iterations to which the researcher has been given access) required only that the building's exterior "reflect the status of the Supreme Court as the repository of New Zealand law and the apex of the third arm of Government" and "not be ostentatious but [...] be of substance and of enduring design.” While indigeneity has often been expressed in New Zealand's built environment through an engagement with $\mathrm{M}$ ori iconography (for example in Cliff Whiting's sculpture for the Christchurch courthouse Nga Kete Wananga ("The Baskets of Knowledge", 1989) (Ill. 80)), this approach was specifically excluded in the Supreme Court project. As outlined in Chapter IV, it was clearly articulated by those involved in the Supreme Court project design development interviewed for this research that the Court architecture should avoid culturally specific symbolism or iconography in the building in order that no cultural ownership of building (and thus, by extension, the institution) be expressed or implied. This stance infers an assumption that the cultural neutrality of the building was desirable in order to express the cultural impartiality of 
the institution. Although couched by interviewees in terms that presented this direction as relating to any of New Zealand's constituent cultural groups, the assumed concern of the judiciary was that, given the tribally specific nature of traditional $\mathrm{M}$ ori building $\mathrm{crafts}^{201}$ there could be no way of "de-tribing" any M ori iconography employed, which could lead to the impression that a particular hap or iwi held some sort of dominion over the building.

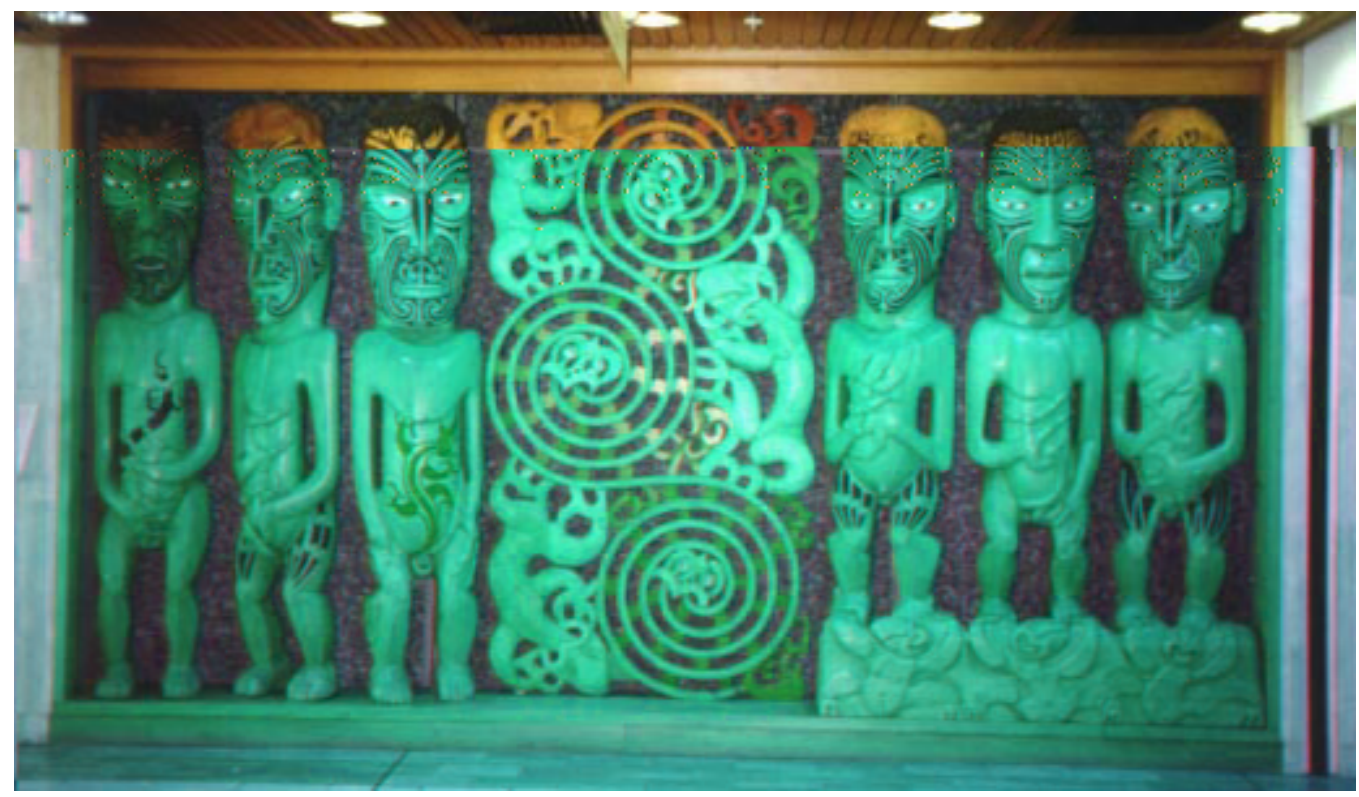

Ill. $80 \quad$ Nga Kete Wananga, Cliff Whiting, 1989

That point of view is not without rational basis. As Julie Paama-Pengelly notes, traditional $\mathrm{M}$ ori art and design express and reinforce whakapapa ${ }^{202}$ and $\mathrm{m}$ tauranga $\mathrm{M}$ ori ${ }^{203}$ which

\footnotetext{
${ }^{201}$ By crafts I refer to carving, weaving and construction techniques employed in traditional Maori buildings.

202 The term "whakapapa" refers to a person's genealogy, but extends far beyond immediate familial relationships to include tribal relationships with anthropomorphised entities such as meeting houses and mountains.

${ }^{203}$ The term “m tauranga M ori” refers here to traditional M ori knowledge, understanding, wisdom and skills.
} 
permeate $\mathrm{M}$ ori culture and society and thus express strong tribal individuation. ${ }^{204}$ According to tikanga $\mathrm{M}$ ori any role of expressing a $\mathrm{M}$ ori cultural perspective in the Supreme Court building would fall to Te Atiawa, who have tangata whenua ${ }^{205}$ status in relation to the Supreme Court site. ${ }^{206}$ Indeed Te Atiawa did play an important role in the Supreme Court project, being consulted by the architects in relation to the selection of a waka huia to be displayed alongside the Queen Anne inkwell ${ }^{207}$ and laying three mauri stones from Mount Taranaki at the steps of the Supreme Court during construction, representing the life force or the essence of the building and the important work to be conducted there in the future. ${ }^{208}$

It is suggested that attempting to achieve cultural neutrality in a civic building such as a courthouse is nonsensical and, moreover, impossible. As has been discussed above, the OHCB is exemplary of late $19^{\text {th }}$ century judicial architecture in New Zealand and the Supreme Court, while certainly representing an evolved version of the traditional courthouse, still embodies an overwhelmingly English lineage in its design. No one considering the Supreme Court could reasonably hold a view that the building has at its heart and heritage anything other than the inherited English courthouse model, albeit updated for the $21^{\text {st }}$ century. The formal relationship of the Supreme Court building to the OHCB is perceptibly one of cohesion and complement, not challenge and departure. The colonial status quo reigns

\footnotetext{
204 Paama-Pengelly, Māori Art and Design, 10.

205 This term is commonly translated as "local people; hosts; people of the land."

${ }^{206}$ Wellington City Council, Wellington City District Plan (Wellington, New Zealand: 2000), para. 2.5.1.

207 Wilson, discussion. This would seem to support the Chief Justice's comments (see p 148 supra) that the waka huia selected has some Te Atiawa provenance.

208 Georgina Te Heuheu, "Mauri Stone Laid at New Supreme Court" (3 March 2009) (Wellington, New Zealand) http://www.beehive.govt.nz/release/mauri-stone-laid-new-supreme-court
} 
and is evident in symbolic gestures such as the New Zealand coat of arms over the entrance and in the courtroom, the relationship of the Queen Elizabeth II-gifted inkwell to the waka huia of intentionally obscure provenance, and the nods to $\mathrm{M}$ ori culture in the borrowed artworks in the secure, private areas of the courthouse. Even the so-called tukutuku screens in the courtroom could more easily be described as having a traditional European tabby weave pattern (Ill. 81-83). The entire architectural tradition and heritage embodied in building is $\mathrm{P}$ keh , making the Court itself a symbol of $\mathrm{P}$ keh cultural ownership over the administration of justice in this country. The significance of this condition should not be downplayed.

While the situation concerning tribal identification within carvings and weaving may be problematic, it is suggested that it would not have been impossible to resolve. Many examples exist of architecture mediating the uncertain ground of representing more than one M ori tribal group in a coherent and cohesive way. Fairly recent examples which may be cited are the carved meeting houses Te Hono ki Hawaiki at Te Papa Tongarewa/Museum of New Zealand (Ill. 84) and Te Wharenui Ngakau Mabaki at the Unitec Institute of Technology Mount Albert campus in Auckland (Ill. 85). The reality of the situation is, however, that the architects (at the direction of their clients) deliberately avoided references to cultures other than $\mathrm{P}$ keh in what was ab initio an impossible attempt to make the building appear culturally neutral. To many immersed in the hegemonic cultural order this move can actually be viewed as very successful; nothing in the building challenges a view that the citizens the Court serves - New Zealanders of every ethnicity, race and creed - have identities or interests that diverge in any way from the hegemonic culture. However, it is suggested that this move, rather than being encompassing of the nation as a whole, is alienating of those 


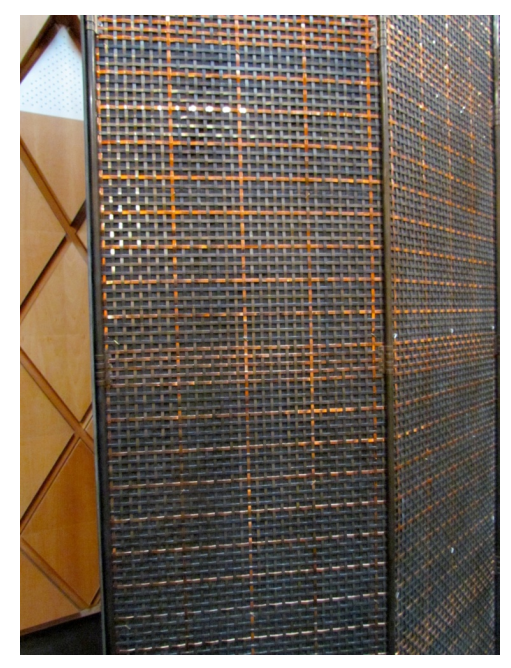

Ill. 81 Woven copper screens

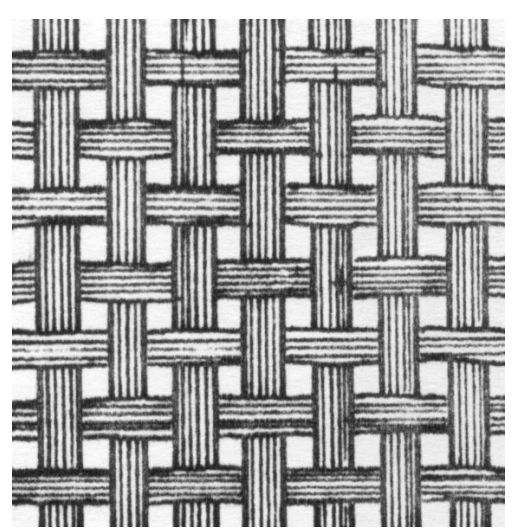

Ill. 82 Plain weave fabric

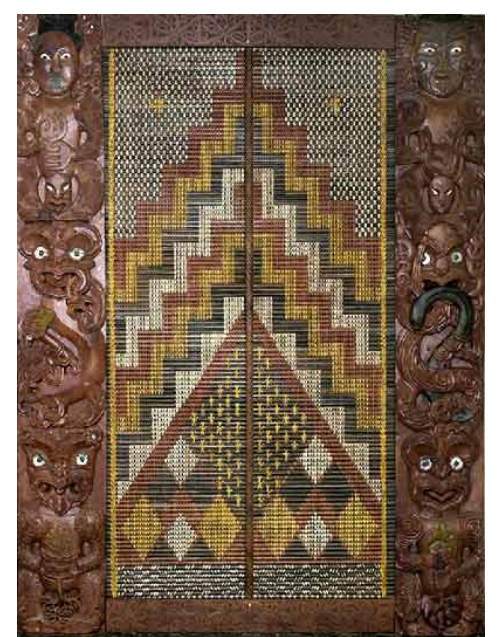

Ill. 83 Tukutuku panel 


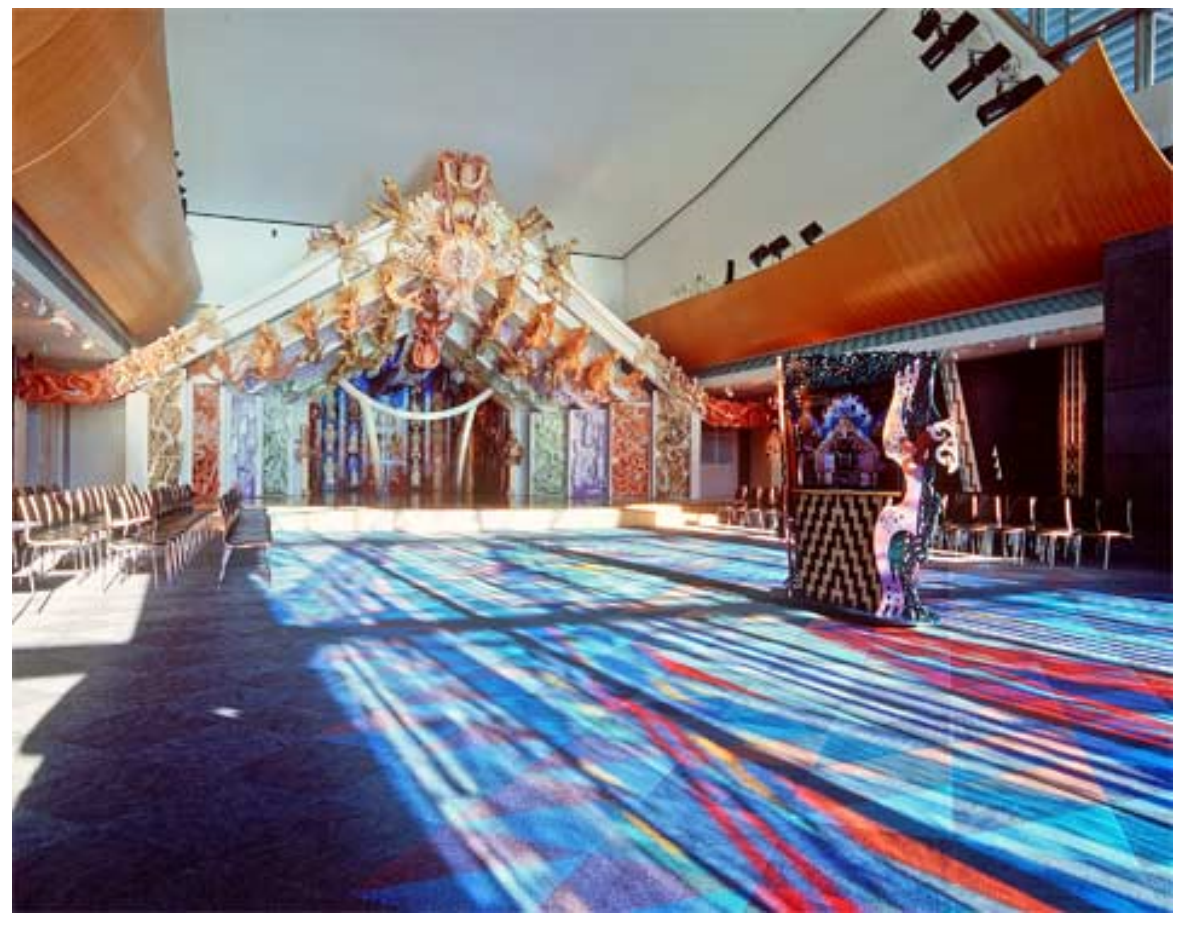

Ill. 84 Te Hono ki Hawaiki, Cliff Whiting, 1989

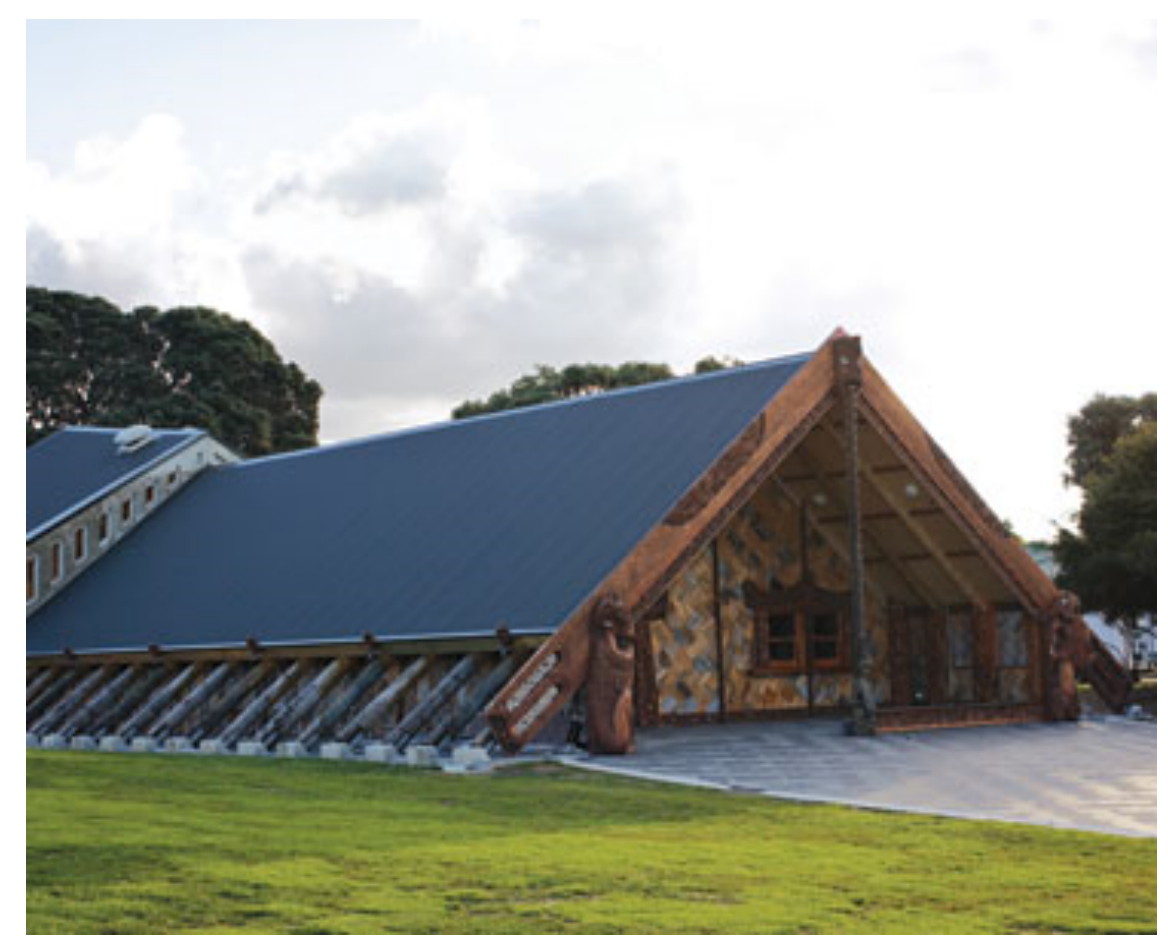

I11. 85 Te Wharenui Ngakau Mabaki, Lyonel Grant, 2009 
who do not identify with the hegemonic order. Moreover, this approach is particularly concerning given the centrality of the living Treaty relationship to New Zealand's legal, constitutional, and social fabric which was outlined in Chapter II. So, if the Court avoids non-P keh cultural ownership and expression of the significance of the Treaty relationship between $\mathrm{M}$ ori and the Crown, how then is the indigeneity of the Court expressed? How is this expression to be read and understood?

The most significant symbolic move in the Supreme Court building is the use of indigenous natural resource emblems as symbols of nationhood, namely the pōhutukawa/rātā screen and the kauri cone. If cultural symbolism is undesirable for the Supreme Court, what makes symbolism drawn from New Zealand's natural environment appropriate?

As Bell \& Lyall observe, one effect of globalisation has been an urgent assertion and celebration of national identity. Drawing on Benedict Anderson's conceptualisation of nationhood as an imagined community, ${ }^{209}$ Bell \& Lyall summarise the criteria for present-day nationhood as:

[A] specific piece of territory; common language; social, cultural, or economic traditions and institutions; artefacts, rituals, and practices passed from one generation to the next; respect for emblems and symbols; myths of origin; a common sense of history; an imagined idea of community with fellow nationals; a sense of distinction from other nation groups; pride and sorrow about past achievements and disasters; and shared hopes for a shared future. ${ }^{210}$

\footnotetext{
${ }^{209}$ See Benedict Anderson, Imagined Communities. Reflections on the Origin and Spread of Nationalism (rev. ed.) (London: Verso, 2006).

${ }^{210}$ Claudia Bell \& John Lyall, The Accelerated Sublime: Landscape, Tourism and Identity (Westport, Conn.: Praeger, 2001), 171.
} 
Using these criteria, where is New Zealand, a bi-(or multi-)cultural nation, to find its symbolic common ground? Many of the criteria could potentially be politically and socially divisive (or contentious at least), for example cultural institutions and contested territories. New Zealand's natural environment, however, is a widely respected, cohesive symbol which supports the imagined ideal of nationhood. According to Bell \& Lyall, the reason for the adoption of landscape as national symbol is that:

Nature predates recorded human history. The past brings with it thousands of years of myths and legends about nature untainted by humanity, visions of primeval forests, mysterious mountains, pellucid lakes; a nature modified only by the elements, not by human activity. ${ }^{211}$

The landscape, innocent bystander free of the shackles of subjective human history, therefore becomes something which is part of all New Zealanders without belonging to any one person or group, a common ground free of cultural ownership, instantly recognisable as "New Zealand." It is the ultimate, enduring, cohesive symbol. ${ }^{212}$ As MoJ officials noted, this recognisability was a key reason the natural environment references in the Court's design were so attractive to the project's proponents:

I think it's fair to say that it was really important that the building represented New Zealand and that it was recognisable by people of New Zealand as something that derived from their country. So that took you pretty quickly to flora and fauna as opposed to other cultural connotations. ${ }^{213}$

The landscape symbolism in the Supreme Court is not so generic as common New Zealand motifs of "beach", "birds", "mountain" or "forest" however, the symbols are very specific

\footnotetext{
211 Ibid.

212 A well-known M ori proverb states "Whatungarongaro te tangata, toitu te whenua" (Each generation passes in its turn, but the land remains).

${ }^{213}$ Hampton/Jeppesen, discussion.
} 
trees: kauri, $\mathrm{p}$ hutukawa and $\mathrm{r} \mathrm{t} \quad\left(\right.$ Ill. 86-88).${ }^{214}$ For Philip Simpson the reasons for selecting these symbols is clear:

$[T]$ here are just a handful of native plants that are readily recognised by most New Zealanders: cabbage trees and flax for their distinctive form, kauri for its remarkable size [...], kanuka and manuka because of their floral displays and widespread occurrence, and kowhai for its noticeable yellow flowers. $\mathrm{P}$ hutukawa and $\mathrm{r} \mathrm{t}$, however, are known and appreciated for all of these. ${ }^{215}$

Kauri, $\mathrm{p}$ hutukawa and $\mathrm{r} \mathrm{t}$ are cherished by New Zealanders and feature prominently in the lists of protected trees in many parts of New Zealand, for example the $\mathrm{p}$ hutukawa in the grounds Old Saint Pauls Church in Wellington and in the grounds of Parliament. ${ }^{216}$ P hutukawa have even been planted along the Supreme Court's street frontages (Ill. 89). Such is the ubiquity of $\mathrm{p}$ hutukawa in Wellington that many people mistakenly consider it native to the region; in fact, (and perhaps ironically) $\mathrm{p}$ hutukawa were first planted in Wellington in 1880 , contemporaneous with the construction of the $\mathrm{OHCB} .^{217}$

Kauri, $\mathrm{p}$ hutukawa and $\mathrm{r} \mathrm{t}$ are also tree species loaded with historical, social, and cultural meaning for $\mathrm{M}$ ori and $\mathrm{P}$ keh New Zealanders alike. Simpson's monograph, $P \quad$ butukawa and $\mathrm{R} \quad t \quad$ New Zealand's Iron-hearted Trees, describes the meaning attached by $\mathrm{M}$ ori to $\mathrm{p}$ hutukawa and $\mathrm{r} \mathrm{t}$ thus:

\footnotetext{
${ }^{214}$ In the case of the screen, the $\mathrm{p}$ hutukawa and $\mathrm{r} \mathrm{t}$ symbols merge, symbolising the meeting in middle of the country of the North Island $\mathrm{p}$ hutukawa (Meterosideros excelsa), the northern $\mathrm{r}$ t (Meterosideros umbellata) and the southern $\mathrm{r}$ t (Meterosideros robusta). Wilson, discussion.

215 Philip Simpson, P butukawa and R $t$ : New Zealand's Iron-hearted Trees (Wellington: Te Papa Press, 2005), 198.
}

${ }^{216}$ Notably, a protected p hutukawa tree stands opposite the offices of Warren and Mahoney in The Terrace, Wellington. This is apparently coincidental, however - as stated at n. 150 (supra) the screen was designed out of the firm's Christchurch office. Wilson, Discussion.

217 Simpson, $P$ butukawa and $\mathrm{R} \quad t, 208$. 
Te $r$ whakaruruban is a concept that seems to represent best the core of the $\mathrm{M}$ ori response to

$\mathrm{r} \mathrm{t}$ (including $\mathrm{p}$ hutukawa). The phrase is used to refer to people who are particularly well thought

of, comparing them in a positive way to the structural and ecological aspects of the tree - it means,

literally, 'to provide shelter'. From the botanical standpoint, there are several characteristics of $\mathrm{r} t$

that correspond to the qualities of a person who gives shelter, in particular the great size of some trees,

their strength and their longevity. A person given the appellation 'te $r$ t whakaruruhau' would have

commitment, wisdom, a commanding presence, and a strong sense of place and belonging. He or she would have the personality to lead and protect others, and the resources to provide for them. In addition, such a person would show the way for others, perhaps descendants, to follow a similar pathway. ${ }^{218}$

Kauri also have significant anthropomorphic symbolism in Māori culture; former prime minister Helen Clark noted the passing of the Māori queen Te Ariki Dame Te Atairangikaahu as the falling of a mighty kauri, ${ }^{219}$ while New Zealand's largest known living kauri tree bears the name of the Māori deity Tāne Mahuta. ${ }^{220}$ Kauri are symbols of the pioneering spirit of immigrant Europeans who felled timber and dug kauri gum in the very early days of New Zealand's settlement, but are also symbols of native flora and fauna conservation efforts in the $20^{\text {th }}$ century. Pōhutukawa (a coastal species) and rātā (a mountain tree with northern and southern variants) romanticise care-free summers and the harshness of the alpine environment respectively (Ill. 90). As symbols of nationhood kauri,

\footnotetext{
218 Simpson, $P$ butukawa and $\mathrm{R} \quad t, 131$.

${ }^{219}$ Helen Clark, “Te Ariki Dame Te Atairangikaahu” (15 August 2006)

http://www.beehive.govt.nz/node/26785

220 See Department of Conservation - Tane Mahuta Track http://www.doc.govt.nz/parks-andrecreation/tracks-and-walks/northland/kauri-coast/tane-mahuta-track/. In traditional M ori cosmology, $\mathrm{T}$ ne Mahuta was the son of the sky father, Ranginui, and the earth mother, Papatuanuku. It was $\mathrm{T}$ ne Mahuta who separated his parents' tight embrace, thus creating the heaven-earth dichotomy. T ne Mahuta is considered father to all living creatures of the forest, including mankind. See Margaret Orbell, The Concise Encyclopedia of $M$ ori Myth and Legend (Christchurch: Canterbury University Press, 1998).
} 


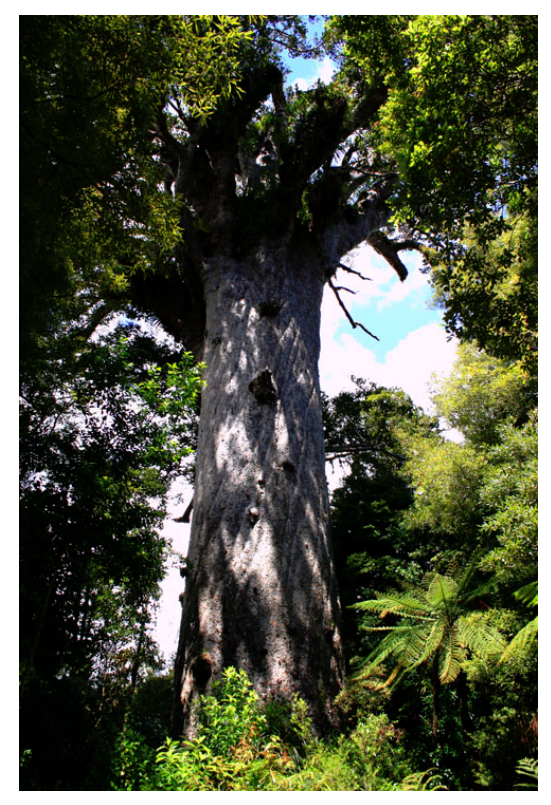

Ill. 86 Kauri tree

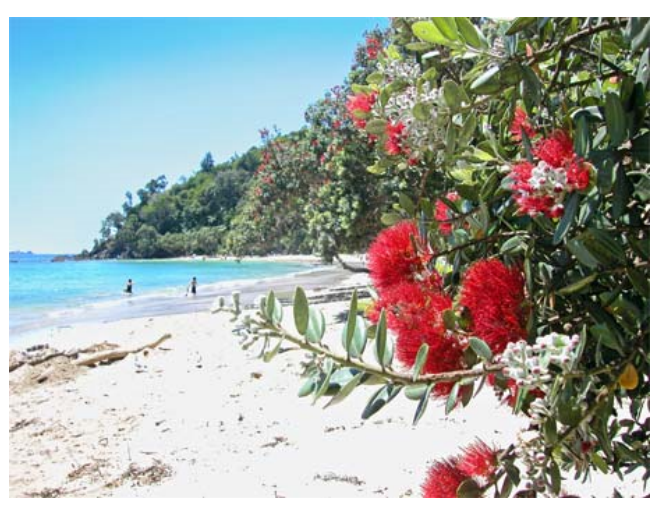

Ill. 87 P hutukawa blossoms

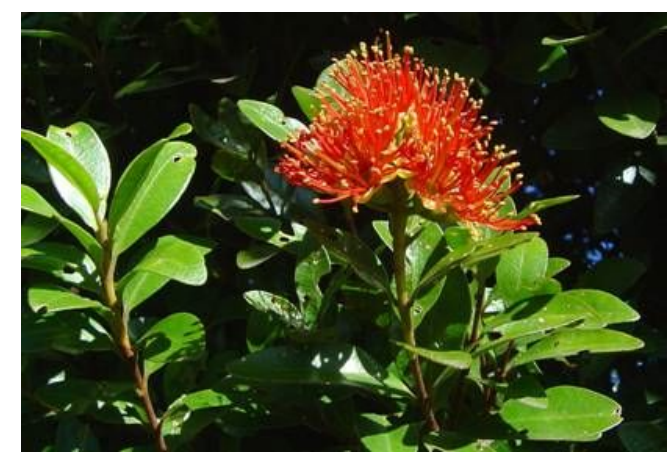

Ill. $88 \quad \mathrm{R} \quad \mathrm{t}$ blossoms 
$\mathrm{p}$ hutukawa and $\mathrm{r}$ t can be everything to everyone and have represented New Zealand in a multitude of representational forms, from stamps and postcards to banknotes and beer labels, from television advertisements for electricity generation companies to medals for the 1990 Commonwealth Games in Auckland (Ill. 91). ${ }^{221}$

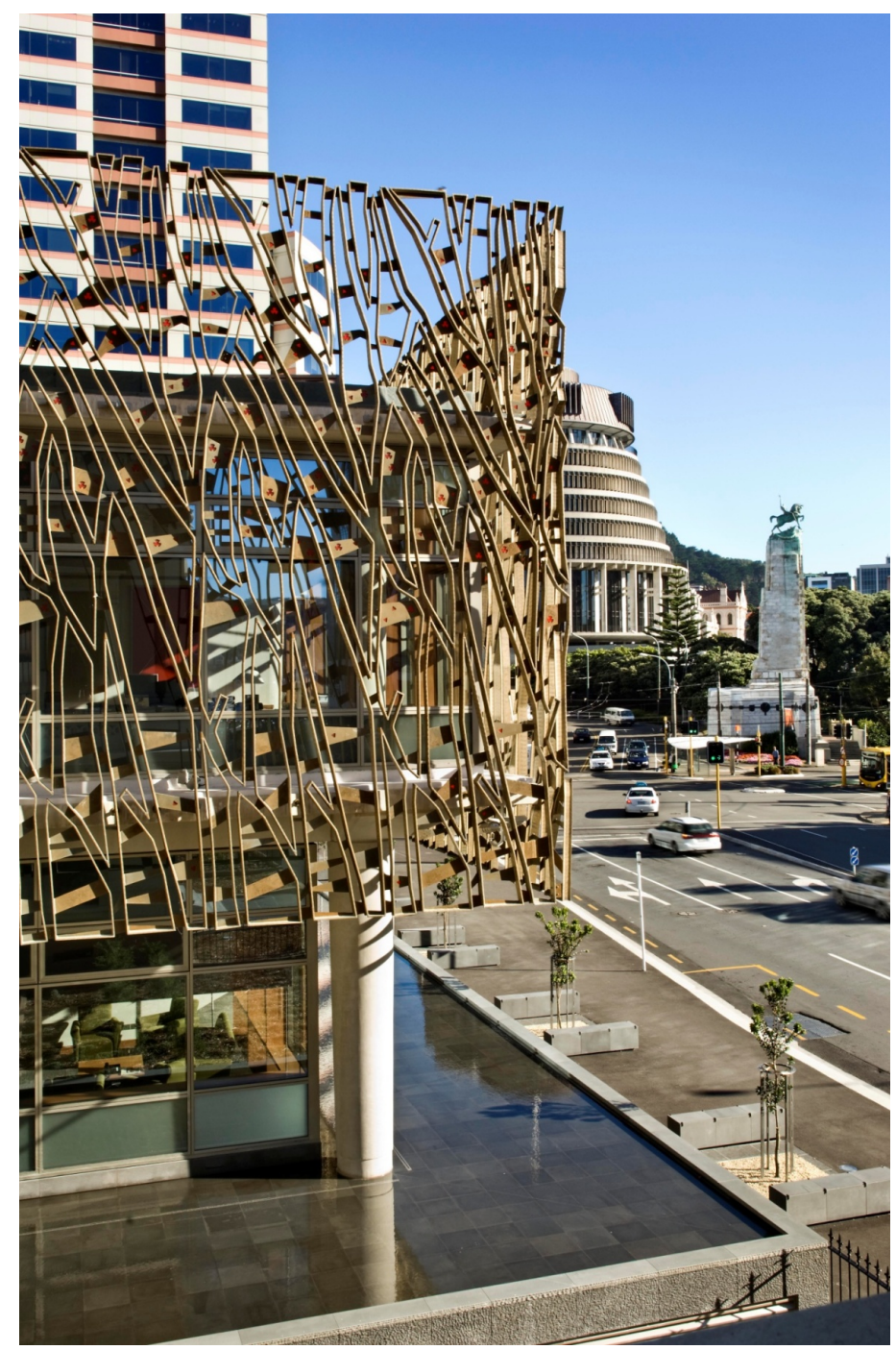

Ill. 89 P hutukawa planted on Whitmore Street frontage

${ }^{221}$ Simpson, $P$ butukawa and $\mathrm{R} \quad t$, p. 258. 


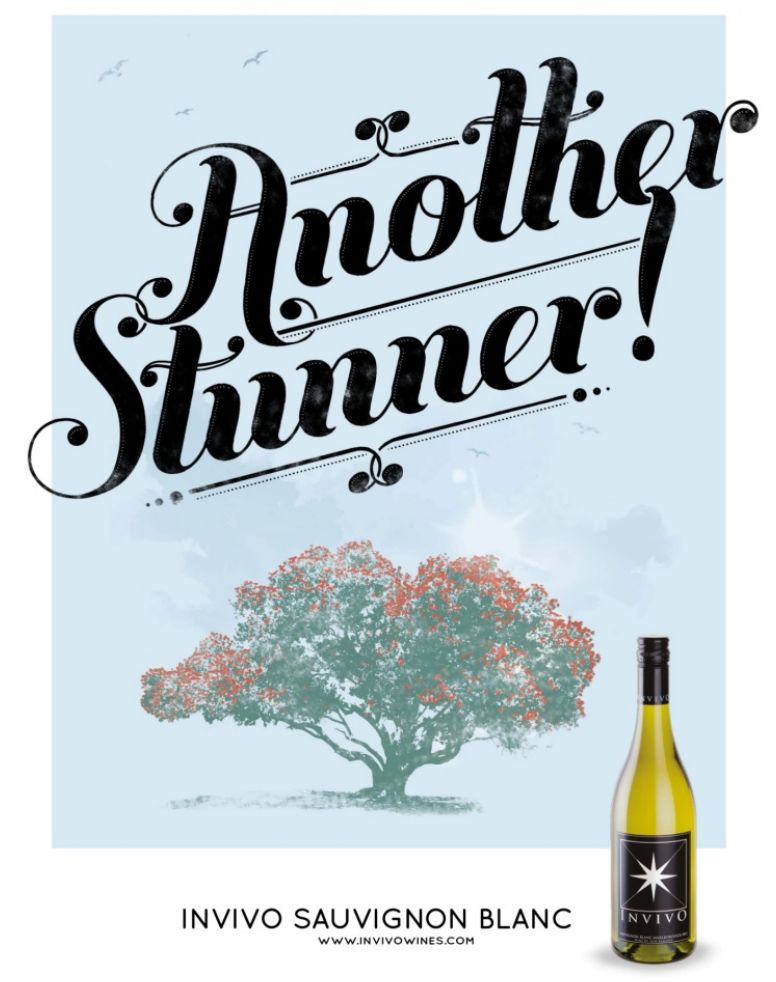

Ill. 90 An advertisement relying on $\mathrm{p}$ hutukawa's links with the New Zealand summer

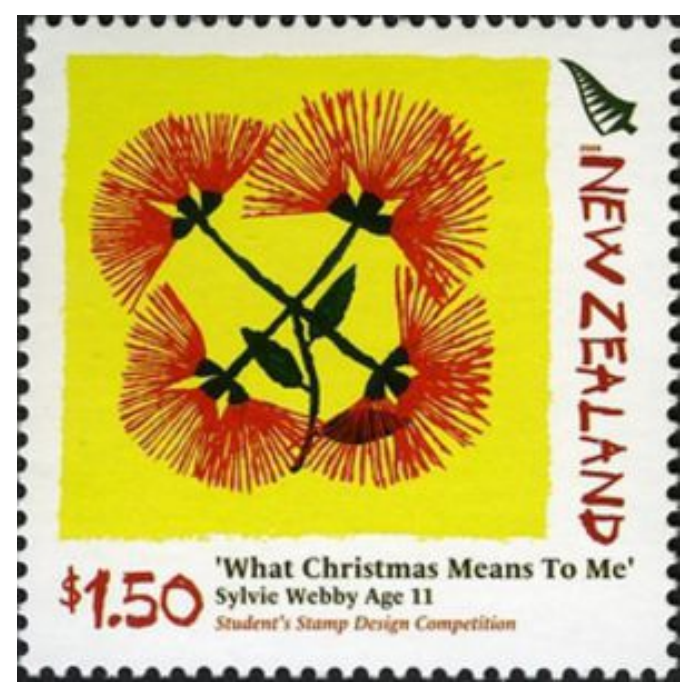

Ill. $91 \quad P$ hutukawa on a New Zealand postage stamp 
Because of $\mathrm{M}$ ori connections with kauri, $\mathrm{p}$ hutukawa and $\mathrm{r} \mathrm{t}$, appropriating them symbolically also permits a conflation of the "native" with the "indigenous" whereby M ori interests can easily be subjugated into the notion of the prehistoric nature of landscape. This "land before time" conceptualisation of natural resource symbolism can also be used to reinforce a romanticised connection with the land, a strategy employed by American President Franklin D. Roosevelt in his promotion of nature preservation:

[Roosevelt] believed that the sublime landscape was not only inspiring for its romantic spirit, but also an important part of his nation's history, and embodied national characteristics and the democratic ideals of the nation. It was worth preserving for those reasons. The lack of cultural history in a new land meant a turning to nature instead, to emblematize the nation's historic identity and uniqueness. ${ }^{222}$

That said, the point was made in Chapter III that any given symbol stands for a field of meaning; it must therefore be recognised that even the landscape does not always offer a stable point of reference:

While many New Zealanders define their (imagined) sense of national and cultural identity in terms of their relationship with the land, this embodies a range of landscapes and of symbolisms that often are at odds with one another. ${ }^{223}$

In the case of the New Zealand Supreme Court, however, it is suggested that the perceived eternalness of the natural world is intentionally drawn upon to lend legitimacy and indigeneity to the institution. Recalling Gusfield's characterisation of symbolic gestures as cohesive or differentiating explored in Chapter II, it is suggested that the value of landscape

\footnotetext{
222 Bell \& Lyall, The Accelerated Sublime, p. 176.

${ }^{223}$ Thierry Jutel, "Lord of the Rings: Landscape, Transformation, and the Geography of the Virtual" in Claudia Bell and Steve Matthewman (eds.) Cultural Studies in Aotearoa New Zealand. Identity, Space and Place (Auckland: Oxford University Press), 54-65, 57.
} 
symbolism in the Supreme Court is that it is a cohesive gesture which permits an identification by all New Zealanders with a sense of nationhood that is personal yet collective, as opposed to ethnically derived symbolic gestures which are, by their very nature, differentiating.

This is a significant expressive function of the Supreme Court building. It is important to emphasise here that the foregoing discussion is not intended to suggest that an either/or dichotomy exists in the types symbols that might be employed in the Supreme Court to signify judicial aspirations in New Zealand. Rather it is suggested that both culturally referential differentiating gestures (acknowledging and reinforcing the constitutional involvement of the Court in the extant $\mathrm{M}$ ori-Crown Treaty relationship) and nationally cohesive gestures (providing a reference point outside the traditional and thereby emphasising the super-national nature of the Court) could (and arguably should) have been made in this building. More is needed than an inkwell and waka huia to satisfy that demand. Observers are still left questioning what the Supreme Court has to say about the nature of NZ justice, today and into the future. Perhaps the answer to that question is that it is not so much the content but rather the process of justice in New Zealand that is important. This is the subject of the next section, The Rule of Law and Parliamentary Sovereignty.

\section{The Rule of Law and Parliamentary Sovereignty}

As was outlined in Chapter II, the rule of law is a fundamental tenet of our legal system and one so constitutionally important that upholding it is recognised as a key purpose of the Supreme Court. There are two key aspects of the rule of law that are particularly pertinent to the present discussion: 1) access to justice, and 2) the institutional independence of the 
Supreme Court, tempered by its subjugation to Parliamentary sovereignty. This section explores how the architecture of the Supreme Court complex expresses these two aspects.

\section{Access to Justice}

As one of the key policy drivers for patriating New Zealand's court of final appeal, the idea of "access to justice" has been somewhat nebulously employed by a variety of stakeholders in relation to the Supreme Court. It certainly encompasses the jurisdictional access to the Court enabled by the broadening of rights of appeal under the SCA, as opposed to the relatively limited rights of appeal to the Privy Council. It also refers to the public's physical and symbolic access to the Court and its processes, a quality which American researchers on courthouse design Pati, Bose \& Zimring call “openness.” As the LRCWA clearly expressed in the Review of the Justice System consultation document:

Law courts display a myriad of approaches to space enclosures, courtroom layout, and circulation management. Many courts evoke classical themes with a strong infusion of hierarchy and clear delineation of space. The 'vision' many courts embody is one of authority, tradition and exclusion. The spaces are not just separated from the outside world. Each internal space is discrete; courtrooms, registry areas, galleries, chambers, jury box, deliberation room and in the courtroom itself the bench, the bar tables and the dock. The enclosing may be as much psychological as physical. Not only are there walls, railings and barriers; there are also language, traditions and rules. Courts are perhaps the most segregated and segregating public buildings in contemporary cities. ${ }^{224}$

In the research by Pati, Bose \& Zimring, openness reveals itself architecturally in conceptualisations of accessibility, transparency, exposure, organisational clarity, illumination,

${ }^{224}$ LRCWA, Consultation Papers, 1026. 
and inclusiveness. ${ }^{225}$ Taking as their starting point expressions of openness as a key late- $20^{\text {th }}$ century political ideology in U.S. architecture, ${ }^{226}$ the researchers investigated expressive attributes of judicial architecture that revealed notions of openness in the design.

Courthouses were chosen for the study due to their "significant symbolic and functional performance."227 It is suggested that Pati, Bose \& Zimring's conceptualisations of "openness" listed above are precisely the types of architectural device employed by the Supreme Court's architects to convey the judiciary's desired sense of access to justice. Accordingly they provide a useful framework for analysing the Supreme Court building in this regard.

\section{Accessibility}

Accessibility is conceptualised by Pati, Bose \& Zimring in three ways: to the site, to the building, and within the building. Site accessibility means ease of access to the site in terms of physical accessibility and proximity to other important buildings in the area since it eliminates special planning by the public for a courthouse visit. ${ }^{228}$ Accessibility to the building at the street-building interface is a significant indicator of openness for Pati, Bose \& Zimring. Architectural devices employed to enable building accessibility might include articulated entrances, visibility of public entry, invitingness of the public entry, mitigation of

\footnotetext{
225 Debajyoti Pati, Mallika Bose, \& Craig Zimring, "Rethinking Openness: Courthouses in the United States" Journal of Architectural and Planning Research 24:4 (Winter, 2007) 308-324.

226 Pati, Bose \& Zimring, "Rethinking Openness," 309. See also LRCWA, Consultation Papers, 1026, where openness to the sky and air is associated also with openness to public complaint, scrutiny and accountability, but also possibly open to threats, corruption and political interference: "Openness can be seen as both a characteristic of architectural design and of the imagination of those who manage and occupy the space."

${ }^{227}$ Pati, Bose \& Zimring, "Rethinking Openness,” 311.

${ }^{228}$ Ibid., 312-3.
} 
entry security devices, and easy accessibility for all. ${ }^{229}$ Articulated entrances might be large and grand, or involve a contrast in form or materiality from the majority of the building. ${ }^{230}$ Articulation also aids visibility of the public entrance and thus legibility of the entrance for the public. ${ }^{231}$ Creating an inviting public entry (through, for example, some form of processional approach to the building) ${ }^{232}$ and having multiple public entries (i.e. increasing the porosity of the building) $)^{233}$ can suggest to the public that a courthouse is more accessible, as can mitigating the obtrusiveness of security devices ${ }^{234}$ and easy accessibility for all, especially for the physically challenged. ${ }^{235}$ The final conceptualisation of openness through accessibility suggested by Pati, Bose \& Zimring is that within a building, which may be provided by multiple circulation routes to internal spaces. ${ }^{236}$

Accessibility is evident in the Supreme Court building in many of the ways suggested by the Pati, Bose \& Zimring research. The siting of the Court is such that public access is permitted to all four elevations of the building. The complex is also within relatively close proximity to many major public nodes, including the House of Representatives, the Beehive, other courts and government buildings; the central train and bus stations; the Lambton Quay/Golden Mile commercial district; Victoria University of Wellington law and commerce

\footnotetext{
${ }^{229}$ Ibid., 313.

${ }^{230}$ Ibid., 313-4.

231 Ibid., 314.

232 Ibid.

233 Ibid., 314-5.

234 Ibid., 315.

235 Ibid.

236 Ibid.
} 
faculties; major hospitality areas; and the Wellington waterfront. The entrance to the Supreme Court is clearly legible from Lambton Quay and although there are no public entrances to the Supreme Court on the other facades of the building, it is suggested that the legible lack of other entrances actually aids accessibility in a building of this scale by focusing attention on the main entrance. The orientation of the entrance onto Lambton Quay perhaps does not maximise its potential invitingness (as discussed in Chapter V, one critic described this as a "lost opportunity" 237 ), but the broad steps leading to the entrance and careful mitigation of entry security devices (the discrete bollards, the liquid softness of the horizontally deep reflecting pools, and off-axis positioning of the security scanner to the left of the public entrance) aid perceived and real accessibility. Ramp access to the same main entrance (rather than to a secondary entrance as is sometimes the case with public buildings) assists accessibility for people with physical movement limitations. Once inside the building, the courtroom is similarly accessible by the public, with a clearly legible, wide open reception area, welcoming concierge, and information videos to help first-time visitors come to grips with the history and function of the Court. The two public access points to the courtroom are clearly visible from the main entrance. Even the Registry office interface, unobstructed by any perceptible security measures, give a sense of an accessible court.

\section{Transparency}

For Pati, Bose \& Zimring, transparency (which may be defined as a condition of being easily seen through or understood, easily discerned, or obvious, open and ingenuous) refers to the notion that a courthouse is not open if it is opaque and invariably relates to perceived or real

237 See p. 103. 
visual linkage, both inside-out and outside-in. ${ }^{238}$ In this way transparency is closely linked with accessibility. Inside-out transparency is said to link users to vistas and other important landmarks in the vicinity and thus imparts a sense of belonging to the community, while linkages from the outside to interior (especially public) spaces is said to convey the transparency of the State's functions to the public. ${ }^{239}$

This notion of transparency requires more detailed consideration in relation to the Supreme Court building, especially since transparency was a key design outcome sought by the judiciary. ${ }^{240}$ Pati, Bose \& Zimring's suggestion that outside-in transparency is perceived to convey official transparency is supported by Deborah Asher Barnstone's work The Transparent State ${ }^{241}$ which provides some insight as to why the concept featured so clearly in the judges' requirements. Barnstone contends that, since the end of the Second World War, the concept of transparency came to be employed in western political spheres to denote democratic, open, and physically and intellectually accessible government. As noted in Chapter III, architecture has long been employed by those in power to convey political values. Harold D. Lasswell speculates in The Signature of Power that the extent to which a government operates in closed (versus open) spaces connotates the degree to which that authority wishes to share power with outsiders. Whereas totalitarian regimes exclude the public from their sites of power, democratic governments permit transparency and

\footnotetext{
238 Pati, Bose \& Zimring, "Rethinking Openness," 315.

${ }^{239}$ Pati, Bose \& Zimring, "Rethinking Openness,” 316.

240 Wilson, discussion.

241 Deborah Ascher Barnstone, The Transparent State. Architecture and Politics in Postwar Germany (New York: Routledge, 2005).
} 
permeation through large windows and doors. ${ }^{242}$ Writing on architectural transparency in the German Federal Republic, Barnstone found that " $[\mathrm{t}]$ ransparency began as a metaphor for a desired condition, but became an analogy for democracy in [West] Germany as it was embodied in architectural projects over the last 50 years." ${ }^{243}$ For Barnstone the formal, spatial, and stylistic use of transparency in West German architecture of the late $20^{\text {th }}$ century is analogical in that it establishes an explicit structural alignment between two represented situations which then projects inferences. ${ }^{244}$ In the case of the Supreme Court this analogy suggests an alignment between the architectonic transparency of the building and the transparent structure of the judicial system and the society it serves.

It is important to note, however, that there is no such thing as a "democratic" (or, for that matter, "fascist" or "communist") architecture; transparency per se does not denote open process, but our cultural milieu is such that we are willing to read openness in the analogy of transparency, as illustrated by the Pati, Bose \& Zimring research. Visual accessibility remains a strong analogy for openness, accessibility, checkability, honesty and egalitarianism, but it is an attractive ideal rather than a secured fact. As Barnstone observes:

In fact, a truly transparent society and democracy does not exist. [...]. The ideology supporting transparency has persisted in spite of these facts. [...] [T] ransparent government is supposed to act as a

\footnotetext{
${ }^{242}$ Harold D. Lasswell, in collaboration with Merritt B. Fox, The Signature of Power: Buildings, Communication, and Policy (New Brunswick, N.J.: Transaction Books, 1979), cited in Goodsell, Civic Space, 29.

${ }^{243}$ Barnstone, The Transparent State, 13.

${ }^{244}$ Barnstone, The Transparent State,12, citing Dedre Gentner, Keith J. Holyoak, and Boicho N. Kokinov (eds). The Analogical Mind (Cambridge: MIT Press, 2001).
} 
preventative measure, a guarantee. It offers the false hope that things and events that are visible are controllable..$^{245}$

That said, promoting that ideal is especially important in the case of such a significant (yet unelected and rarely publicly criticised) constitutional body as the judicial system. Therefore transparency is employed as the primary architectural analogy to convey the concept of transparent administration of justice, since complete transparency in the judicial system is a myth.

However, where the analogy is accepted by the public the building itself becomes a symbol for the (idealised) transparency of the system. This is the value of the architectural analogy whether or not the system is truly transparent, the symbol of the system - the Supreme Court building - embodies the analogy in the hope that the system functioning within always lives up to its symbolic representation. The transparency of the building suggests that the conditions for transparency of the judicial system are manifest. ${ }^{246}$

Judith Resnik \& Dennis Curtis suggest, however, that transparency in architecture is not ideology-driven but rather a function of technological advancement in the $20^{\text {th }}$ century. ${ }^{247}$ For them, this explains why civic buildings such as the Supreme Court are more transparent today than, say, the OHCB. It is suggested that Resnik \& Curtis' view does not explain the level of transparency incorporated into civic buildings in the late $20^{\text {th }} /$ early $21^{\text {st }}$ centuries, where greater transparency is not required for the functional performance such buildings and in fact pose greater security risks than less transparent buildings; nor does it take account of

\footnotetext{
245 Barnstone, The Transparent State, 2.

${ }^{246}$ Barnstone, The Transparent State, 11.

${ }^{247}$ See Resnik \& Curtis "Representing Justice".
} 
the express intentions of the clients and architects involved in such projects, as revealed in both the Pati, Bose \& Zimring research and this study. As Christian Norberg-Schultz has observed, a window may function as a mere hole in the wall, or it may dematerialise that wall - the difference between perforating apertures and expansive window walls is both technical and conceptual. ${ }^{248}$

As described in Chapter $\mathrm{V}$, transparency is a fundamental architectural device utilised in the Supreme Court building. Curtain wall glazing covers the majority of the building enabling unobstructed outside-in visual contact to all public spaces of the court. The $\mathrm{p}$ hutukawa/r t screen provides security, shading and privacy to the first floor of the courthouse while not restricting the inside-out transparency which visually connects the judges and their clerks with Parliament and the Beehive, the various government departments and other courts located in the vicinity, the inner city commercial district, and the wider public and community. While the screen device has been described by some critics as a "strange" and "inappropriately veiled" image of transparent justice, ${ }^{249}$ the Chief Justice has described with approval the "loving embrace" of the screen. ${ }^{250}$

\section{Exposure}

Many of the respondents in the Pati, Bose \& Zimring research suggested that judicial architecture is not open if it is not available for interaction and engagement in the judicial process. The concept of exposure relates to the visibility to the public of a courthouse at

\footnotetext{
${ }^{248}$ Christian Norberg-Schultz, Genius Loci: Towards a Phenomenology of Architecture (New York: Rizzoli, 1979), 67, cited in Goodsell, Civic Space, 36-7.

${ }^{249}$ See Wellington City Council, Council Decision - Notice of Requirement: Supreme Court of New Zealand (12 April 2007), para 3.1, and Wilson, et al., "Natural Justice," 60.

${ }^{250}$ Sian Elias, "Supreme Court Opening Speech.”
} 
local and broader urban scales and is thus related (but not identical) to concepts of accessibility. Local scale exposure might be enabled through selection of a prominent site in a block or neighbourhood, while city scale exposure in the Pati, Bose \& Zimring research typically related visibility from major transportation corridors such as highways. ${ }^{251}$ In the Supreme Court complex, exposure seems to have been more a corollary of siting contingencies rather than intention. That said, the exposure level of the Court at the local level is very high being at the intersection of a number of arterial transport routes in a key area of the central city.

\section{Organisational clarity}

Pati, Bose \& Zimring found that a lack of legibility to the public of the functions and spaces within courthouses was analogous to closed doors, whereas encouraging exploration of spaces and reducing way-finding problems promoted openness. ${ }^{252}$ Organisational clarity was a key concern of the Supreme Court's architects ${ }^{253}$ and is evident in the legibility of the spaces to which the public has (and also does not have) access. For example, upon entering the building the concierge desk is very clear to the visitor as a place to get information, just as the entrance to the courtroom is clear. On the other hand, while the location of the library is clearly visible to the public, the internal glazing is opaque and the access to the library is not in the public area, thus reducing confusion about whether the library is open to the public.

\footnotetext{
251 Pati, et al., "Rethinking Openness," 317.

252 Ibid., 317.

${ }^{253}$ Wilson, discussion.
} 


\section{Illumination}

Linked with the concept of organisational clarity in the Pati, Bose \& Zimring research was that of illumination - that the better illuminated the interior of a courthouse was, the better it could be understood and therefore be considered more open. ${ }^{254}$ Illumination is a key device employed in the Supreme Court complex and one closely aligned with (and a function of) transparency devices. Daylight illuminates all areas of the Supreme Court building, even the library, stereotypically a dark and dusty space. The courtroom skylight and cone penetrations allow daylight to pass deep into the heart of the building. Similar passive daylight illumination devices are found in the OHCB's Courtroom 1 floorlights, but these do not have the organisational clarity or transparency functions associated with illumination in the Supreme Court. Artificial lighting of the Supreme Court complex at night (both architectural light of the exterior facades and interior down lighting) serves to illuminate and expose the complex in the dark.

\section{Inclusiveness}

The final conceptualisation of openness found by Pati, Bose \& Zimring is that of inclusiveness, which the researchers defined as including non-traditional public functions within courthouse spaces which invite people who would not normally have cause to visit a courthouse into the building and thus expose them to the workings of the court. Suggested uses might include large atria available for public use during off-times and weekends, exhibition spaces, and restaurants or cafes. ${ }^{255}$ As noted in Chapter IV, consideration was given in the briefing stage of the Supreme Court project to incorporating commercial floor

\footnotetext{
254 Pati, et al., "Rethinking Openness," 318.

255 Ibid., 318-9.
} 
space into the brief but the idea was rejected in favour of maintaining the typological purity of a courthouse. While this reduces potential daily public interaction with the Supreme Court, it arguably promotes the clarity of the complex as symbol of the judicial system.

\section{Parliamentary sovereignty}

As discussed in Chapter II, the Supreme Court plays a fundamental role in New Zealand's constitutional framework. As one of three branches of Government under the constitutional separation of powers, the Court maintains an institutional distance from the legislature and the executive and enjoys powers which enable it to perform its "check and balance" function vis-à-vis the other two branches. It is suggested that having a stand-alone Supreme Court building speaks in and of itself of the independence of the institution. Just as the legislature has the House of Representatives and the executive the Beehive, so the judiciary now has the Supreme Court. The complex stands as an emblem of the third branch, but fittingly it is further removed from Parliament and the Beehive geographically, just as its constitutional functions are further removed from the much closer workings of the Government with the legislative law maker. As required by the Supreme Court brief, the building is not ostentatious; it is, however, iconic of the institution and symbolic of justice. As previously noted, the Court's strong corner siting means that is it not hidden behind other buildings and it enjoys clear sight lines to the other branches of Government, and vice versa. The Supreme Court building is also suitably isolated from commercial interests. As already mentioned, there was consideration at the beginning of the project to incorporating a tower above the court to garner commercial leasing revenue. This option was discarded, and rightly so there would never be a serious suggestion that the Beehive or Parliament could have a number of floors leased out to recover costs. While the Supreme Court is constitutionally 
independent from Parliament and, together with the Executive, enjoys equal status as a branch of government, the lower elevation of the Supreme Court provides an apt analogy that Parliament is sovereign and the only body with the full power to make law within New Zealand's constitutional framework, ${ }^{256}$ something that the siting of the Beehive fails to communicate. That said, there is an irony in this regard in the slight turning off-axis from Parliament of the main entrance to the Supreme Court which might be seen by some as an appropriate expression of institutional independence.

${ }^{256}$ Constitution Act 1986, section 15(1). 


\section{VII.}

\section{Conclusion}

As found by this study, the Supreme Court Act 2003 expresses that the judicial aspirations of the Supreme Court are to recognise the independence and historical and contemporary context of the Court, to provide an accessible, indigenous court of final appeal which understands and provides for the unique conditions of New Zealand's justice system, and one which affirms the constitutional significance of the sovereignty of Parliament and the fundamental role of the rule of law in New Zealand society.

The guiding assumption of this study has been that the architecture of the Supreme Court complex legibly responds to its layered (but not always publicly accessible) briefing process, a process which expresses the aspirations of the New Zealand justice system at the beginning of the $21^{\text {st }}$ century. Analysis of the New Zealand Supreme Court complex's legislation and briefing documents revealed the judicial aspirations of the Supreme Court. Through analysis of archival research, interviews and the Court's built form, Chapter VI of this thesis then assessed the success of the Supreme Court complex as an embodiment of judicial aspirations at the beginning of the $21^{\text {st }}$ century. Drawing on that assessment, this chapter summarises the significant findings of the study.

The first section of Chapter VI, Heritage and Independence, found that the architectural relationship between the OHCB and the new Supreme Court building embodies the strong heritage of the new institution within the history and traditions of the New Zealand judicial system. This relationship successfully anchors the Court in an extant judicial tradition and 
gives the new institution a strong identity moving forward. Viewed in the context of that relationship, the architecture of the Supreme Court building recognises that one of the Court's aspirations is to look to the future, embodying innovation in planning and form that express the maturity of New Zealand's judicial system and the independence of the Supreme Court from its colonial heritage. A key finding of this section was that rather than being a significant break with tradition, the Supreme Court represents a distinctive step in the evolution of New Zealand's judicial architecture.

By synthesising theories of how landscape references can act as cohesive symbols of national identity, An Indigenous Court explained how the architecture of the Supreme Court complex draws on native tree species as symbols of New Zealand's natural environment in an attempt to express another judicial aspiration, the indigeneity of the Supreme Court. Kauri, $\mathrm{p}$ hutukawa and $\mathrm{r} \mathrm{t}$ references in the Court's architecture represent New Zealand in a culturally cohesive yet non-specific manner that satisfies the express desire of the judiciary to avoid cultural ownership of the building. It is suggested, however, that by avoiding pluralistic references the Supreme Court complex fails to appropriately recognise, support and advance the fundamental relationship between $\mathrm{M}$ ori and the Crown established by the Treaty of Waitangi, New Zealand's founding document and the basis for constitutional government in New Zealand. This compromises the success of the architecture in expressing the judicial aspirations of the Court as they relate to $\mathrm{M}$ ori, aspirations which have been consistently articulated by promoters of the Supreme Court since the Reshaping New Zealand's Appeal Structure discussion document in 2000.

The final section of Chapter VI, The Rule of Law and Parliamentary Sovereignty, showed that there are significant expressions of concepts relating to the rule of law in the architecture of 
the Supreme Court. The architecture of the Supreme Court building communicates ideals of institutional openness through a design that promotes the physical accessibility of the courtroom to the public (including by persons with physical disabilities); metaphorical accessibility through transparency (in terms of both public engagement with the ritual of justice and connection of the judiciary with the community which it serves); exposure of (and therefore familiarity with) the courthouse as symbol of the justice system; and organisational openness through spatial clarity and legibility. Day- and artificial lighting are also used to enhance the legibility of the interior and perception of transparency. This section also illustrated a number of urban design aspects of the Supreme Court's architecture which reinforce tenets of Parliamentary sovereignty and judicial independence within New Zealand's constitutional framework.

In summation, this study shows that the architecture of the Supreme Court complex is largely successful in expressing judicial aspirations of recognising the heritage and independence of the Court, its "New Zealand-ness", and its commitment to a number of fundamental constitutional tenets. Significantly, however, the architecture of the Supreme Court fails to appropriately engage with the constitutional significance of the on-going M ori-Crown relationship embodied in the Treaty of Waitangi. The intentional rejection of any form of non-P keh cultural identity in the Supreme Court promotes fundamental questions as to the present and future of New Zealand's judicial system: Does "Justice" in New Zealand require a dismissal of cultural pluralism? Or is the Supreme Court building perhaps accurately representative of a justice system that, even in the $21^{\text {st }}$ century, struggles to understand and provide for New Zealand's cultural pluralism? Both are anachronistic and concerning propositions. 
While the contemporary expressive value of the Supreme Court complex can be revealed in the manner shown by this study, it must be recognised that there are limitations on how far that unveiling can extend. The disconnect between the judicial aspirations regarding the role of the Treaty in New Zealand's jurisprudence expressed in the Supreme Court's constituting legislation and the expression of aspirations in the architecture of the Court reveals some of the complexity of the briefing process undertaken in relation to New Zealand's civic architecture, some of which is publicly accessible, some of which is not. It is suggested that this discrepancy highlights a layering of aspirations that occurred in the Supreme Court complex's briefing process. Compared with aspirations expressed in the public record, unofficial aspirations behind a design can only be suggested by the built form.

It must also be recognised that the Supreme Court complex will develop in meaning over time. The architectural expressions assessed by this study reveal the aspirations of those involved in the establishment of the institution at the beginning of the $21^{\text {st }}$ century, but the complex's symbolic capital will either increase as its symbolism is accepted and affirmed by the community as the ideal expression of New Zealand's justice system, or such resonance will not occur and the Court's symbolic function will diminish. Accordingly, care ought to be taken not to limit the building's expressive value to the here and now, to too literal a reading of its component parts; after all, qui haeret in littera baeret in cortice - he who chokes on the words, chokes on the substance. ${ }^{257}$ In the words of the Chief Justice, the Rt. Hon Dame Sian Elias:

The Supreme Court, like any Court, is not a building. Nor is it simply made up of the Judges and court staff who occupy the office today. They serve an idea which is greater than the sum of the built

${ }^{257}$ Lord Linley in Smith v McArthur [1904] AC 389; (1904) NZPCC 323 (Privy Council). 
and living parts of today's Court. [...] Altogether, this is a confident building which looks with optimism to the future of the Court within our society. The building challenges all who work in the Court to fulfil the aspirations for justice with which it was set up. [...] Such shared expectations are sometimes disappointed but over the long haul they are shared values which bring us together as a people. In this Court the hopes of the people who have gone before and those yet to come can be felt. May we in our time work to fulfil those hopes here..$^{258}$

${ }^{258}$ Sian Elias, "Supreme Court Opening Speech." 


\section{Appendices}

Appendix I

Appendix II

Appendix III

Appendix IV

Appendix V
Supreme Court Legislation (excerpts)

Supreme Court Complex - Briefing Documents

Supreme Court Complex - Architectural Drawings

Chris Cochran, Supreme Court. 42 Stout Street. Conservation Report for The

Ministry of Justice (2006) (excerpts)

Supreme Court Complex - Selected Credits and Awards 


\title{
Appendix I
}

\section{Supreme Court - Legislation (excerpts)}

\section{Supreme Court Act 2003 - Legislative History}

\author{
9 December $2002 \quad$ Introduction (Bill 16-1) \\ 17 December 2002 First reading and referral to Justice and Electoral Committee \\ 16 September 2003 Reported from Justice and Electoral Committee (Bill 16-2) \\ 7 October $2003 \quad$ Second reading \\ 8, 9 October $2003 \quad$ Committee of the whole House (Bill 16-3) \\ 14 October $2003 \quad$ Third reading
}

\section{Supreme Court Bill (First Reading)}

\section{Clause $3 \quad$ Purpose}

The purpose of this Act is to-

(a) establish the Supreme Court of New Zealand as the court of final appeal for New Zealand, and provide for its jurisdiction and related matters; and

(b) end appeals to the Judicial Committee of the Privy Council from decisions of New Zealand courts; and

(c) make related amendments to certain enactments relating to courts or judicial proceedings.

\section{Clause 13 Criteria for leave to appeal}

(1) The Supreme Court must not give leave to appeal to it unless it is satisfied that -

(a) the proposed appeal involves a significant issue relating to the Treaty of Waitangi or tikanga Maori; or

(b) the proposed appeal involves some other matter of general or public importance; or

(c) a substantial miscarriage of justice may have occurred, or may occur unless leave is given; or

(d) the proposed appeal involves a matter of general commercial significance; or

(e) it is necessary in the interests of justice for the Court to hear and determine the proposed appeal. [...] 
Supreme Court Act 2003

Public Act 2003 No 53

Date of assent 17 October 2003

\section{Section 2 Commencement}

This Act comes into force on 1 January 2004.

\section{Section 3 Purpose}

(1) The purpose of this Act is-

(a) to establish within New Zealand a new court of final appeal comprising New Zealand judges-

(i) to recognise that New Zealand is an independent nation with its own history and traditions; and

(ii) to enable important legal matters, including legal matters relating to the Treaty of Waitangi, to be resolved with an understanding of New Zealand conditions, history, and traditions; and

(iii) to improve access to justice; and

(b) to provide for the court's jurisdiction and related matters; and

(c) to end appeals to the Judicial Committee of the Privy Council from decisions of New Zealand courts; and

(d) to make related amendments to certain enactments relating to courts or judicial proceedings.

(2) Nothing in this Act affects New Zealand's continuing commitment to the rule of law and the sovereignty of Parliament.

\section{Section 6 Supreme Court established}

This section establishes as the court of final appeal for New Zealand a court of record called the Supreme Court of New Zealand.

\section{Section $7 \quad$ Constitution of Court}

(1) The Supreme Court comprises-

(a) the Chief Justice; and

(b) not fewer than 4 nor more than 5 other Judges, appointed by the Governor-General as Judges of the Supreme Court.

(2) The Supreme Court's jurisdiction is not affected by a vacancy in the number of its Judges. 


\section{Section 13 Criteria for leave to appeal}

(1) The Supreme Court must not give leave to appeal to it unless it is satisfied that it is necessary in the interests of justice for the Court to hear and determine the proposed appeal.

(2) It is necessary in the interests of justice for the Supreme Court to hear and determine a proposed appeal if-

(a) the appeal involves a matter of general or public importance; or

(b) a substantial miscarriage of justice may have occurred, or may occur unless the appeal is heard; or

(c) the appeal involves a matter of general commercial significance.

(3) For the purposes of subsection (2), a significant issue relating to the Treaty of Waitangi is a matter of general or public importance.

(4) The Supreme Court must not give leave to appeal to it against an order made by the Court of Appeal on an interlocutory application unless satisfied that it is necessary in the interests of justice for the Supreme Court to hear and determine the proposed appeal before the proceeding concerned is concluded.

(5) Subsection (2) does not limit the generality of subsection (1); and subsection (3) does not limit the generality of subsection (2)(a).

\section{Section 18 Chief Justice, and seniority of Judges}

(1) The Chief Justice is the head of the New Zealand judiciary, and has seniority over the other Judges of the Supreme Court.

(2) Other Judges of the Supreme Court appointed on different dates have seniority among themselves according to those dates.

(3) Other Judges of the Supreme Court appointed on the same date have seniority among themselves as follows:

(a) Judges who have been Judges of the Court of Appeal are senior to Judges who have not been Judges of the Court of Appeal:

(b) Judges who have been Judges of the Court of Appeal have among themselves the seniority they would have if still Judges of the Court of Appeal:

(c) Judges who have not been Judges of the Court of Appeal but have previously been Judges of the High Court have seniority among themselves according to their seniority as Judges of the High Court:

(d) Judges who have not previously been Judges of the High Court but have previously held other judicial office in New Zealand are senior to Judges who have not previously held judicial office in New Zealand.

(4) Judges of the Supreme Court are senior to the Judges of the Court of Appeal, and to the Judges of the High Court who are not Judges of the Supreme Court.

(5) This section applies only to permanent Judges.

\section{Section 42 Ending of appeals to Her Majesty in Council}

(1) No appeal to Her Majesty in Council lies or may be brought from or in respect of any civil or criminal decision of a New Zealand court made after 31 December 2003- 
(a) whether by leave or special leave of any court or of Her Majesty in Council, or otherwise; and

(b) whether by virtue of any Act of Parliament of the United Kingdom or of New Zealand, or the Royal prerogative, or otherwise.

(2) Subsection (1) is subject to section 50 . 


\section{Appendix II}

\section{Supreme Court Complex -Briefing Documents}

II.1 Chief Justice, Memorandum - Supreme Court Project PSG, Premises Brief Provisions (7 November 2003)

II.2 Supreme Court Premises Brief Version 1 (24 March 2006)

II.3 Office of the Minister for Courts, Memorandum for Cabinet Policy Committee (c. March 2006)

II.4 Supreme Court Permanent Premises Project, Option C (Modified) Parameters (6 April 2006)

II.5 Supreme Court Premises Brief Version 2 (18 July 2006)

II.6 Supreme Court Draft Premises Brief Version 3 (6 December 2006)

II.7 Supreme Court Premises Brief Version 4 (28 March 2007) 


\section{MEMORANDUM}

TO: $\quad$ Kim Williams, Property Manager,Ministry of Justice

cc. Jo Lake, General Manager, Higher Courts

FROM: $\quad$ Chief Justice

SUBJECT: SUPREME COURT PROJECT PSG Premises Brief Provisions

Date: $\quad 7$ November 2003

1.

As discussed at our meeting yesterday respond with my views on some suggested compromises to the design guidelines contained in your project brief emailed to me on 5 November. I follow your numbering. I should emphasise that the jurdiciary had no input into the original proposals for the supreme Court. Ny understanding is that neither of the proposals submitted for Cabinet approval met the functionality requirements identified only when discussions were held with the PSG over the last two months.

2. You have identified a number of revisions you are considering. Trespond simply in terms of the functionality of what is proposed, rather than its architectural merit. The comments are also based on your advice that the building is expected to have a life of 100 years. That has direct implications for matters such as the number of Chambers to be provided and the space required for judicial support staff. It must be anticipated that within the next 100 years the size of the Bench (given the existing statutory prescription of 6 Judges) will increase to 7. At present it is proposed that each Judge will have one law clerk. That is well out of line with the resources available in Canada and Australia and the capacity to accommodate 2 clerks per Judge over the next 100 years seems extremely modest provision. I should emphasise therefore that many of the comments I make are equally applicable if the building is to have a life of 20 or 50 years.

3.

Some of the suggestions made I consider to be neutral in terms of their impact upon functionality (although they may have considerable amenity impact). Some are undesirable because they will impact upon the collegiality of the court, although it cannot be said that 
they would be unworkable. The court will lose some important benefits, however. Collegiality, as we have discussed, is extremely important, particularly in a new court. The aim should be to co-locate Judges to the greatest extent possible, so providing them with opportunity to work together rather than in silos.

1.1 Elevation of Chambers to first floor and car parking to ground level

This proposal is neutral. The elevation of the Chambers may have benefits in terms of security. The car parking and storage space provided in ground level car parking will hawever be severely restricted. More generous car parking provision and storage provision would seem wise.

\subsection{Reduction from 7 Chambers to 6}

This proposal is unacceptable. The Act provides currently for the appointment of 6 Judges. It would be inconsistent with a longer term view to exclude provision for a further appointment to the court over the life of the building.

Locate Chambers on same filoor bui allow separation of them between old and new building

This proposal is highly undesirable. It would separate the Judges and inhibit the collegiality of the court.

Again this is highly undesirable because of its effect on collegiality.

\section{Re-locate Chief Justice's administration support team off site}

This proposal is highly undesirable. It would necessitate the absence of the Chief Justice from the environs of the court and the other Judges. It may require administrative staff to meet at the Supreme Court in the area reserved for the Judges with associated disruption to the more reflective atmosphere it is hoped to produce at the court. If the Chief Justice has to travel daily to another location to meet with staff, there is loss of time and disruption of the focus required if the Chief Justice is to lead a collegiate court. There may also be security issues. 
The Chief Justice's meeting room receives high use from external members of committees such as the Rules Committee and the Criminal Practice Committee as well as judicial members. Those attending often exceed 12. Use of working space for members of the court would be compromised by shared facilities (as would be the case if the large judicial meeting room on the ground floor is used for that purpose). It is highly desirable to maintain a distinction between areas used for judicial work and those used for administrative purposes for which access by members outside the judiciary is necessary.

Reduction of Chief Justice's administrative support team

The current complement of direct support staff is 5 . It is extremely unlikely that over the term of the building accommodation staff will be restricted to that number.

\subsection{Reduction of judicial clerical support from 2 to 1}

It is unacceptable to have no allowance for growth. As indicated, comparable courts in other jurisdictions already have 2 or more clerks per Sưdge.

1.10 Delete separate judicial staff room/training room Issues of confidentiality and security as well as the constraints of the space, make this solution highly undesirable. The training room for Registry staff is a distinct requirement. Registry staff and judicial direct support staff perform very different functions and are not an integrated working unit because of the differences in accountability.

\subsection{Deletion of collegiate work room}

The suggestion is unacceptable. It would mean that Judges could gather only in the formal setting of the main downstairs conference room, at some distance from their working space, or in each other's rooms. One of the important benefits to be captured from the setting up of the court is to enhance, not diminish, the opportunities for interaction on a working level which is collegial. within their general proximity 
This suggestion is neutral. Some Judges may prefer to have Clerks closer at hand, but it is acknowledged that preference may not be able to dictate the result. It would be acceptable.

Such separation is undesirable because less convenient in terms of access.

Co-late Associates remote from, but on the same floor and within the general proximity of Chambers

Such suggestion is neutral. Some Judges may prefer immediate proximity. Provided the layout is conducive to ready communication, it is likely to be acceptable.

2.1 Deletion of production room

Highly undesirable. With the advent of electronic filing, it is likely that the Registry will have to extend its production of hard copy casebooks. This is an area of considerable activity and noise and does not lend itself into incorporation into other workspace.

This seems inconsistent with the expected life of the building. standing of the building and the need to provide facilities which will help counsel.

4.

As you know, I am of the view that the original plan provided to Cabinet was in fact based on a number of wrong assumptions. My comments and the feedback provided by judicial members of the PSG should not therefore be construed as an escalation of requirements. If the funding constraints prevent the achievement of a building commensurate with the position occupied by the Supreme Court and one which inhibits the manner in which it will work effectively, then it may be preferable to consider other options. They include re-thinking the suitability of the site, or undertaking the 
completion of the courtroom and Registry only, leaving judicial accommodation off-site until sufficient funds can be provided to fit the building to serve as a home for the court for the next 100 years. 


\section{Premises Brief Version 1 \\ 24 March 2006}

The following notes set out the brief for the design development for the Supreme Court (Old High Court Building).

It is intended this brief will be developed through consultation with Key stakeholders in the period April 2006 to July 2006. A finalised version with sign off from stakeholders will be submitted for final approval from the Project Steering Group.

\section{DESIGN GUIDE FOR THE SUPREME COURT OF NEW ZEALAND}

\section{DRAFT March 2006}

\subsection{General}

\section{$1.1 \quad$ Exterior}

The building exterior should reflect the status of the suipreme Court as the repository of NZ law and the apex of the third arm of Government. The building should not be ostentatious.

\subsubsection{Security Considerations}

- All external glazing to have secúrity film

- All external windows which open inust be secured.

- Environmentilal security to be considered in all landscaping.

- External fences must allow high visibility.

- Exteríal security lighting to be discussed.

1.2 Interior IDS to to included.

The interior design of the building must provide good lighting, acoustic coifirol good environmental control and facilitate modern efficient work practices.

Collegiality, as we have discuissed, is extremely important, particularly in a new court. The aim should be to co-locate Judges to the greatest cxtent possible, so providing them with opportunity to work together rather than in silos."

See viemorandum from the Chief Justice, Premises Brief Provisions, 07.11 .03 (paragraph 3)

\section{$2.0($ Registrar (office)
$2.2 \quad$ Meeting room (to adjoin Registrar's room)
$2.3 \quad$ Allow for temporarily manned (2 person) sit down counter with a waiting space for up to 10 persons}

NO. OF REQUIRED STAFF AREA m2 


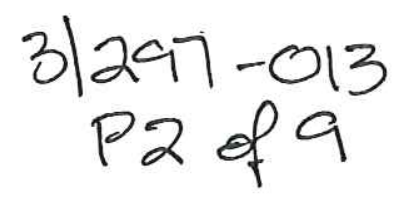

3.0 Public Accessible Area

3.1 Press room (temporarily occupied with up to 5)

3.2 Security Office (Occasionally occupied with 1 person)

3.3 Public Foyer Area (Accommodates 35 people standing)

- $\quad$ Public foyer is suitable as per current size in Old High Couft Building

- $\quad$ CCTV in Foyer with 21 inch screen in Admin area

- $\quad$ Power supply in foyer for Walkthrough or other security

measures

- $\quad$ Provision also needs to be made for the "in cøuttroom images \& sound of proceedings to be transmitted to locations outside of the courtroom i.e. public lobby or to an external location.

- $\quad$ Access doors to be discussed. Mag tock or mortise.

- The public has a basic requirement in that they need to be able to see Justice being done. To this end the ability to see and hear clearly all proceedings is vital.

- A sound system must provide a high quality audio level for all speech from Judges and $G$ ounsel.

- $\quad$ A large LCD screen (or similar) will be needed for the purpose of conveying images to the public gallery. This would service the need for both evidence display $2 s$, well as video conferencing images.

- A system (hearing loops or singilar) providing sound for the hearing inpaired is also a necessity.

3.4 Public Toilets M \& $F$

3.5 1 Disabled Toilet Unisex

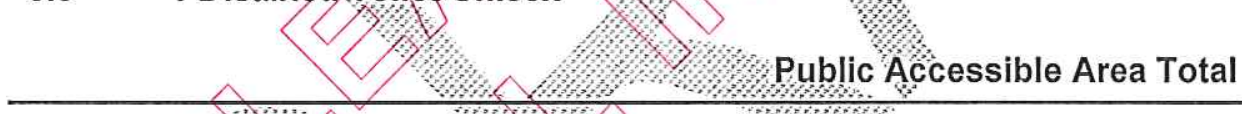

4.0 Registry

4.1. Court Officers wistation

4.2 Admin Support w/station

- 21 inch screen in Admin area for CCTV located in Foyer

Shut down switch in Admin area located in area of Monitor. Must be lever type switch, in an easily accessible position and clearly labelled

4.3 Finance Administrator

4.4 Growth w/station

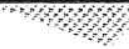


- $\quad$ File and records management system needs to be flexible for variable case files and provide a convenient and durable handling container. Shelving to be sized to suit file container.

- $\quad$ Case load for Supreme Court estimated as 50-80 cases (approximately 700 heard at Court of Appeal) although cases files will likely be large.

- $\quad$ Both electronic and paper files will be required to suit differing work practices

\subsection{Production room}

"With the advent of electronic filing, it is likely that tho Registry will have to extend its production of hard copy casebooks. This is an area of considerable activity and noise and does sot lend itseif into incorporation into other workspace"

See Memorandum from The Chief Justice Premises Briét ciovisions, 07.11 .03 (paragraph 2.1)

$4.8 \quad$ Fax (1)

4.9 Printers (2)

4.10 Mail area

4.11 Coat cupboard

4.12 Cabinets File (6)

4.13 Bookcase (2)

4.14 Cabinet Store/Státionery type (2)

4.15 Paper Recycle Bin

5.0 Staff Facilities

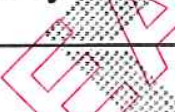

\% Interaction between Registry staff and Judicial support staff should be fostered by provision of common staff facilities.

Staff and Counsel to have separate access from public. Staff to be provided with entry from both Whitmore and Balance Streets if possible.

Access doors to be discussed. Mag lock or mortise.

5.1 Tea-room/Training Room

5.2 Staff Toilets M\&

5.3 Uni-sex shower \& disabled toilet

6.0 Courtroom Areas:

6.1 Courtroom 1

- $\quad$ Court room should provide seating for 30 public.

- $\quad$ Electronic display and video conference facility required in Court Room.

- $\quad$ Transcripts will very rarely be required. If required EFTR 


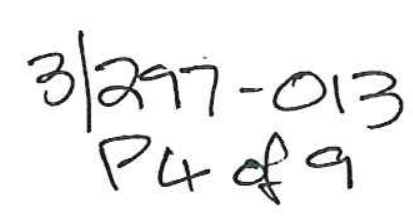

system to be utilised. There must be a barrier between the public area and the body of the court. Barrier to include polycarbonate or the like to a ht of at least $1.7 \mathrm{~m}$. Construction similar to the barrier in Courtroom 1 Wellington $\mathrm{HC}$.

Corridor doors to the side of the Courtroom to have one way vision panels.

The ability to record via cameras is still in need of further discussions, as this will present a number of issues not only for the Judiciary but also for the design team. However, there will be times when video or a visual recording of some type will be required for the news media. TV cameras in court can be distracting and the necessary cabling can be a hazard. We need to look at built-in facilities or the utilisation of the counts own camera recording network to provide footage of kin courtroom" activities to the media. Provision also needs to be made for the "in courtroom" images \& sound of proceedings to be transmitted to locations outside of the courtroon in pe. public lobby or to an external location.

A central lectern will be available for the piesentation of oral submissions. This lectern will be connected to the sound system for projection of the voice as well as for digital recording.

The requirement to provide an accurate record of all proceedings within the Courtroom was been taken one step further in Melbourne with a visual/video recording as vivillas an audio recording.

The source to which these recordings are transported will mostly likely take the form of a digital recording system with the ability by the Judicialy to access these recordings with ease.

In Victoria Australia e ourtroom evidence recording is transcribed by way of a remote transcription centre located in Melboürne and the transcribed data is then sent back to the courtroom. The information yill also be required on line at a later date by the Judge $\sigma_{0}$ others when reviewing the evidence/case in Chantions.

This may mean a software solution that is accessible via the Chamber's équipment that allows for instant playback of a particular case in part or whole if required:

The audio recordings are normally captured by means of microphones placed on the bench, counsel desks with cabling leading back to a basic recording and sound rack controlled by the Court Taker.

These micropioines also have a mute button attached to them for personal activation as the situation may require.

in averseas operations cameras were dispersed throughout the Courtroom in at least 5 positions.

These cameras record the proceedings of the Court and are used at the discretion of the Judge. Again either the Judge or the courrt taker can control these.

There wass also a separate camera usually on or near the Courttakers bench for the screening of evidence both written and physical for record purposes and for playing back on screen within the courtroom for all to see.

The Courts in which these existing systems were viewed were Jury Trial Courts, District and Youth \& Family courtrooms - not Appellant Courts and therefore there maybe some differing needs for the appellant courts that are not readily apparent when looking at recording images.

Their cameras record the Jury, Dock and Witness Stand, a wide angle of the Courtroom and Public seating as well as the Judge (s) on the bench. 


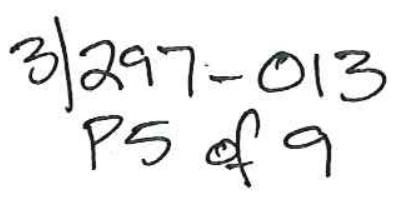

The Supreme Court will not have a Jury, Dock or Witness Stand - so the overall requirement for cameras may reduce accordingly.

Such wholesale fulltime recording - particularly with one camera solely focused on the bench - may not be deemed necessary or appropriate in this Appellant Court.

However a visual (Digital?) record to accompany the audio recording is desired, with control to allow flexible usage and some means of indication when each camera is operating.

The final position of the cameras will be dependent upon direct comment from the Judiciary as to whether or not certain 6.1.1

\section{Bench} recorded angles are considered necessary.

- $\quad$ Bench to be set at low level so that eye height when sived matches standing Counsel. Bench to seat seven Judges with approximately $1.5 \mathrm{~m}$ work space each. Computer screen and

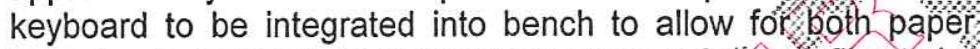
based and electronic work practices. Storage for case files to be provided behind bench and on mobile trolleys

Judges bench must go wall to wall Dufess activators 1 per Judge to be positioned on the privacy pane tof the bench Must be lever type and labelled.

- Whilst seated at the bench the Judiciary will require access to seivices including those already available in Chambers, such as, the secure Judicial server, electronic law library and the Internet as well as the other standard operating functions and software packages

A screen, keyboard and PC should be provided for each Judge. All systems ayallable/for access by Judges within their Chambers should be provided at the bench. An integrated hardware solution should be developed ayoiding the need for laptop use,

The positioning of the screens and keyboards should not compromise the use of the bench for paper layout etc. The hardware should be able to be largely, concealed if the Judges elect not to utilise it and should not be a hindrance to their use of the bench. Screen location must not impede view lines between Judges and counsel.

The use of in bench display units was prevalent in the overseas examples

These screens for displaying the information available on normal top mounted computer screens and corresponding hard drives were builitinto the bench design and mounted at a low angle.

Some examples thad these screens mounted beneath the flat suiface level of the bench itself with the surface of the bench at this point being glass.

The screens we witnessed in Melbourne were approximately 15 -17 inch inonitors.

These screens did not display any of the video fed displays such as out sourced video links or evidence displays. These functions were catered for an additional TV screen, which took up valuable bench space.

The ability to incorporate within the screen the function of a split screen to display not only word documentation but also evidence display or a separate video feed from an outside or pre recorded source is desirable. In the Melbourne County Court the controls for all technology were by way of a "touch screen" mounted on the Court-takers bench.

The control of this display function may remain with the Judges 


\subsubsection{Councel Desks}

or be left to the operating skills of the Court taker

The supply of additional power points and computer jack points to the bench is a standard requirement.

- Counsel desks should be flexible to allow for relocation to cope with up to 20 Counsel. Desks should include movable lectern and be fully wired for IT access.

- $\quad$ Counsel will be required to be seated at the tables provided starting at a distance of approximately $5.5 \mathrm{~m}$ from the bench.

Counsel will also need to have external Internet access to their own Law Library and other material such as their electronic database. It is not envisaged that MoJ will provide PC's/Monitors for Counsel.

- $\quad$ Counsel will also require a clear line of sight to a visual display unit that may be needed to assist during the presentation to the Judiciary.This may take the form of either large LCD (on similar) type screens mounted in full view and in close proxinify to the Counsel table. As a preference this screen shouid also provide display for video conferencing (if required) and be a permanent fixture integrated into the design of the Coúfroom.

Within the tables there will need to be. IT \& power outlets for connection purposes that will enable laptons to be issed to project their images, via the Courr Taker, onto the diski liv units available.

\subsubsection{Press Bench}

Press bench to cater for 6 and facilities for television coverage within Court room,

The press and media must have at the very least the ability to record, via hand written notes, the proceedings of the day.

\section{1 .4} Court Taker

\section{Court Take will re quire desk with audío controls etc.}

The Coúf taker will be responsible for the set up and running of the daily requirements of the supreme Court.

The ability to control the images, sound, evidence recording and the like displayed on whatever the developed final de sign solution is will remain with the Court-taker: It is envisaged that as many as possible of the sound and visual aids available will be pre set and not require any adjustment at all. A touch screen or similar control panel would be envisaged. This may take the form of being able to place something such as a document or transparency on a display yunit and project that to a number of screens for visual access by all interested parties. It may also include the need to display audio/visual feeds from a static source such as a DVD or from a laptop as well as transmit to the viewing screen an image being beamed in from an outside source. The controls should be kept to a minimal size as the space available is very limited and the ideal location for such supporting hardware would ideally be outside the area of the Courtroom.

The lighting to the Courtroom will also be preset to suit the VDU hardware but controls will be provided at the Court takers desk in order to select the appropriate setting.

The supply of additional power points to the Court Takers position is a standard requirement.

\subsection{Judges Assembly / Retiring room}

\subsection{Secure Area:}




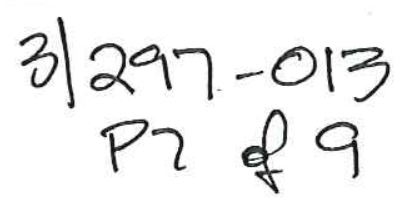

7.1 Lawyers Room with tea-making facility

- A lawyers room will include tea station and access to toilet facilities.

- No changing room necessary as Counsel will likely only be required to wear gowns in court.

- No library facilities will be provided for Counsel. Shelving to be provided in lawyers room.

7.2 Auxiliary room

7.3 Unisex disabled toilet

7.4 Judicial Conference Room

- $\quad$ The Judges conference room may be located near the Court room away from Chambers so as to provide easier access fôr visitors. The conference room may also be used for leave applications. Video conference facilities will be required.

7.5 Catering Kitchen

Secure Area Total

8.0 Judicial Areas:

- A separate room is not required for the Crown Sóficitor as their use will be infrequent

- Provision of garden space for Judges use is desirable. Garden should be in sunny aspect and private.

8.1 Judges Chambers \& Ensuite $(7 \times 35 \mathrm{~m} 2)$

- $\quad$ All Judges Chambers should be co-located however the seventh chamber could be separated if necessary due to planning restrictions.

- Chambers should provide desh and separate work space, Storage should allow for personal reference library (with adjustable open shelving) and cupboard storage for case files, Compüter shoülọ be integrated into workstation. Natural tight should be provided and acoustic privacy is essential. A full en-súte will be provided Services will include the secure Judiciall server, electronic law library and the Internet as weil as the other standard operating functions and software packages

8.2 Common room with kitchenette factitity

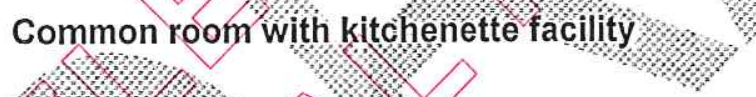

8.3 Nudicial collegiate Room

Judges common room and collegiate work room should be locatednean chambers.

- Enables Judges to gather in the informal setting of the work room, at close proximity to their working space. One of the important benefits to be captured from the setting up of the court is to Enhance the opportunities for interaction on a working level Wioch is collegial

8.4 Chief Justice Chämber \& En-suite

(If the Chief Jis sicic has to travel daily to another location to meet with staff, there is loss of time and disruption of the focus required if the Chief Justice is to lead a collegiate court. There may also be security issues.)

See Memorandum from the Chief Justice, Premises Brief Provisions, 07.11 .03 (paragraph 1.5)

8.5 Chief Justice Support Staff

- Chief Justices support staff should preferably be co-located with Chief Justice.

8.6 Chief Justice meeting room 


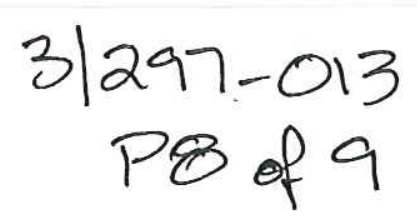

- Should maintain current capacity of 18 people.

It is highly desirable to maintain a distinction between areas used for judicial work and those used for administrative purposes for which access by members outside the judiciary is necessary.

8.7 Judicial Communications Advisor

8.8 Judges Associates (8 @ 12m2)

- $\quad$ Associates must be located next to chamber

8.9 Judges Clerks (16 @ 8m2)

- Clerk to be located close to Associates

8.10 Library (Includes for Judges reading area \& Clerks research area)

- $\quad$ The library is to provide a Judges reading area for periodicals. This should be comfortable quiet space.

- A Clerks / Researchers working area is required in the library.

- 2500 lineal meter of shelving in one dedicated facility

8.11 Librarian

8.12 Toilets M\&F

8.13 Disabled Toilet/Shower

8.14 Utility Room (photo copier/fax/printer/stores)

9.0 Utility Areas:

9.1 IT \& Comms Room

9.2 Cleaners Room

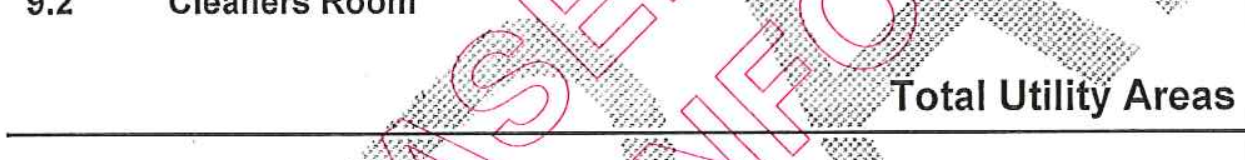

Space requirements

Design Considerations and Circulation space (20\%)

Total Space Required

Space Redundancy due to Design Constraints
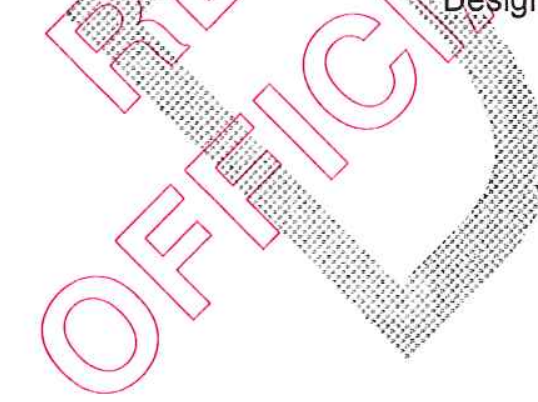

Total Space Required
Total staff at commencement
Total staff growth allowance

Total staff allowance 


\section{Additional Requirements :}

\subsection{Basement}

10.1 Secure parking for up to 20 motor vehicles.

- $\quad$ Secure car parking to be provided in basement and to link by lift access to Chambers

- $\quad$ Sallyport arrangement to be located at the entrance to the basement garage. Two roller doors.

Remotes for roller doors to basement to be programmed on access system.

The entrance to the basement area must be high enough to allow a custodial vehicle to enter.

10.2 Secondary File store (2F/R)

10.3 Secure Rubbish Room

10.4 General Storeroom

10.5 Building Services Plant, Equipment \& Lifts

10.6 Design considerations including circulation, ramps etc $(20 \%)$

\subsection{Items for Clárification}

Total Additional Requirements

- The aporopriateness of the Whitmore Street or Lampton Quay entry as the main entry.

- Identification of préference for either locating Judges clerks with the Associate and dudge (in a suite) or co-locating clerks in a common location near chambers.

confirmation of preference for a collegiate work practice in chambers

Confirmation that the building should acknowledge New Zealand's muiliculturalism, and the addition of Maori cultural elements in Public foyer is appropriate but that these should be excluded from the Court room.

- Number of carpark spaces

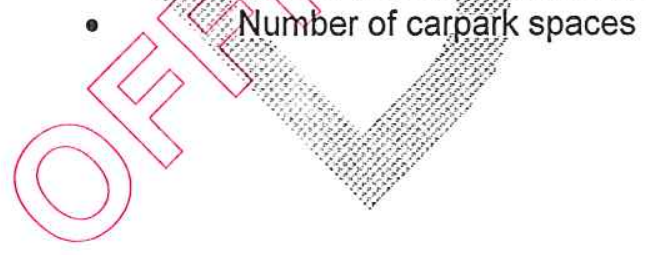




\section{MEMORANDUM FOR CABINET POLICY COMMITTEE}

The Supreme Court - Establishment of Permanent Premises
Options for the Integration of Adjacent Park Space

\section{Purpose}

1. The purpose of this paper is to report back to the Committee on further options for the development of the permanent accommodation for the Supreme Court. The various options have incorporated proposals for a purpose built court chamber on the park site adjacent to the Old High Court Building (OHCB) and the effective utilisation of the OHCB and the park space.

\section{Summary}

2. Since March 2003 when Cabinet approved funding for the Supreme Court, the Ministry of Justice (the Ministry) has worked to develop a functional design solution for the former Wellington High Court building (referred to in this paper as the OHCB). This has been done within certain constraints, namely, an approved appropriation and direction to restore the OHCB without encroacting on the adjacent park.

3. In April 2004, a design concept was developed which incorporated as much functionality as possible while retaining as much of the historic nature and fabrig of the old building as possible given the project constraints.

4. Following consultation with the Historic Places Trust on the proposed design for the redevelopment of the $\mathrm{CHCB}$, the Trust expressed concern regarding the proposed demolition of pars of the building required in order to meet project constraints.

5. The Trust also expressed concerns regarding the proposed changes to the main courtroom in the OHCB (No. 1 Courtroom) which would be used as the Supreme Court courtroom.

6. Since then, a number of alternative options to proceed with the project have been considered which were presented to the Committee for consideration on 17 November 2004.

7. The Committee subsequently invited the then Associate Minister for Courts, in consultation with the Minister of State Services, and relevant officials 
including the Chief Executive of the Ministry for the Environment, to prepare a new paper with proposals for a purpose built court chamber on the park adjacent to the OHCB. The paper was to include proposals for the effective utilisation of the OHCB and park space [POL Min (04) 28/9].

8. Earlier this year, further consultation took place with the Supreme Court Judiciary, the Historic Places Trust, the Minister for Courts and the then Attorney-General and Minister of Finance in regard the use of the OHCB for the purposes of the Supreme Court. The former Attorney-General and I have requested the inclusion of option $C$ (set out below) for consideration by the Committee.

9. In response to the Committee's request, I present the following options in this paper. These options consider:

- Utilisation of the park site;

- Utilisation of the OHCB; and

- Use of the No.1 Courtroom by the Supreme Court.

Also provided is a summary of the consultation/feedback received from various parties regarding the use of the $O H C B$ and adjoining park space for your information.

10. Four high-level design options have been identified and within these, there is flexibility to satisfy some of the preferences identified from the recent consultation. In summary, the four design options are:

A. Utilise the OHCB and the No.1 Courtroom for the Supreme Court with partial demolition of the rear of the $\mathrm{OHCB}$ and construct a single or double level chamber addition which minimises intrusion into the adjoining park site; or

B. Utilise the OHCB and No.1 Courtroom for the Supreme Court without any demolition of the $\mathrm{OHCB}$ and construct a single or double chamber addition which encroaches further into or uses the adjoining park site; or

C. Construct a large new build addition on the park to house the Supreme Court incorporating the court chamber (new courtroom), judicial chambers, library and associated court functions. The addition will have a link to the OHCB.

Restore the OHCB with the exception of the area at the rear of the building which will be demolished. Restore the No.1 courtroom without major alteration which could be utilised as a working court by other jurisdictions (potential usage is currently being explored) and for ceremonial purposes; or 
D. Construct a separate building for the Supreme Court, incorporating all the Supreme Court, on the park site and fully restore the OHCB (no demolition) for use by other jurisdictions and for ceremonial purposes.

11. The fundamental differences between the 4 options described above are summarised as follows:

- Option A proposes the partial demolition of the rear of the old building. The demolition will enable the new chamber addition to be located relatively close to the old building to allow for easy access and flow between the two buildings. The option proposes utilisation of the old No.1 courtroom for the Supreme Court Courtroom, which witl involve/a degree of alteration to the courtroom.

- Option B proposes no demolition and will leave the $\mathrm{OHCB}$ intact.

Linkages to the new addition willinvolve longer distances and may have a disjointed flow resulting in increased space provision. Utilisation of the old No.1 courtroom is proposed for the Supreme Court Courtroom, which will involve a degree of alteration to the courtroom.

- Option C proposes partial demolition of the rear of the OHCB with full restoration of the remaining building including the No. 1 Courtroom (without major alteration). A new court chamber (including ancillary functions) and library will be located within a large new addition with the judicial chambers. This addition will be linked to the OHCB.

This option provides a purpose built court chamber that can meet the functional needs of the Supreme Court without the compromise of the heritage constraints of the No.1 courtroom. Under this option, the No.1 courtroom could be considered for use by other jurisdictions where the layout of the room is a 'better fit'. The OHCB may or may not be utilised by the Supreme Court.

Option D establishes the Supreme Court in a separate building with the OHCB remaining intact and being fully restored. A new court chamber and library would be located in the new complex. The OHCB will not be utilised by the Supreme Court. The OHCB could be used for other judicial or Ministry purposes.

- Options D and to some extent Option C effectively represents two projects, being the establishment of the Supreme Court permanent premises and the restoration of a historic building.

12. It should be noted that within these high level options, there are a number of sub-options relating to preferences for location of some of the Supreme Court 
functionality either in the OHCB or the new addition. These sub-options have not been detailed in full in this paper and will vary the size and cost of the addition. This paper has focussed on high-level concept directions in relation to the utilisation of the OHCB and the park space.

13. The options of a commercial development on the park site that would house the Supreme Court as a tenant or alternative sites to locate the Supreme Court have not been discussed in this paper. These options twere considered and discussed in the paper presented to the Committee on 17 November 2004.

14. Set out below is a summary table and comparative assessment of the four options described above in paragraphs 10 and 11 . Key assumptions relating to the basis of the assessment are provided in Appendix 1 . Sketch plans showing the bulk and location of these options are shown in Appendix 4 and 5. Appendix 6 and 7 show proposed demelition lines on the OHCB. Two lines are shown. One line indicating the removal of the historic additions and the original chambers and the other line indicating removal of the historic additions only. 
OPTIONS SUMMARY \&

COMPARATIVE ASSESSMENT

\begin{tabular}{|c|c|c|c|c|}
\hline OPTION & $\begin{array}{l}\text { Indicative } \\
\text { Duration }\end{array}$ & $\begin{array}{l}\text { Indicative } \\
\text { Cost }\end{array}$ & Parameters & Issues/lmplications \\
\hline $\begin{array}{l}\text { Option A } \\
\text { - Utilise OHCB site } \\
\text { only } \\
\text { - Partial demolition } \\
\text { of the Historic } \\
\text { Building } \\
\text { - No.1 Courtroom } \\
\text { used } \\
\text { - Chamber } \\
\text { addition could be } \\
\text { expanded to } \\
\text { house clerks } \\
\text { - Space vacated } \\
\text { by clerks in } \\
\text { OHCB could be } \\
\text { used for Library } \\
\text { expansion (up to } \\
2000 \text { lin. m), or } \\
\text { - A second level } \\
\text { could be added } \\
\text { to chamber } \\
\text { addition to house } \\
\text { library (up to } \\
2500 \text { lin.m) }\end{array}$ & $\begin{array}{l}31 \text { - } 36 \\
\text { Months }\end{array}$ & $\begin{array}{l}\$ 30.0 \mathrm{M} \text { - } \\
\$ 41.0 \mathrm{M} \\
\$ 30 \mathrm{~m} \text { for } \\
\text { original } \\
\text { chamber } \\
\text { size } \\
\$ 33 \mathrm{~m} \text { for } \\
\text { larger } \\
\text { chambers } \\
\text { to include } \\
\text { clerks } \\
\$ 41 \mathrm{~m} \text { for } \\
\text { larger } \\
\text { chambers } \\
\text { and second } \\
\text { level for } \\
\text { Library. }\end{array}$ & $\begin{array}{l}\text { - Design supported by two } \\
\text { Conservation Architects. } \\
\text { - Notified Resource Consent } \\
\text { required for partial demolition. } \\
\text { - Resource consent not } \\
\text { required for interior } \\
\text { alterations. } \\
\text { - Adjoining park site largely } \\
\text { retained ( } 85 \% \text { to } 70 \% \text { of } \\
\text { current site available for } \\
\text { public amenity). } \\
\text { - Entry from Stout Street, } \\
\text { - Makes good functional use of } \\
\text { the OHCB. } \\
\text { Single or double level building } \\
\text { addition } \\
\text { Development comprises: } \\
2100 m^{2} \text { restoration of OHCB } \\
800 m^{2} \text { basement carpark } \\
\text { - either a } 650 \mathrm{~m}^{2}, 900 \mathrm{~m}^{2} \text { or } \\
1560 \mathrm{~m}^{2} \text { new build addition. } \\
5\end{array}$ & $\begin{array}{l}\text { - Judiciary consider No. } 1 \\
\text { courtroom \& library inadequate } \\
\text { for long term needs and are no } \\
\text { onger supportive of this option. } \\
\text { - An increased chamber addition } \\
\text { (up to } 900 \text { m2) could satisfy } \\
\text { Judicial requirements for clerks } \\
\text { to be co-located with Judges and } \\
\text { Associates. } \\
\text { - A second floor of } 660 \text { m2 added } \\
\text { tothe addition could satisfy } \\
\text { library and/or future growth } \\
\text { requirements. } \\
\text { - HPT will not support demolition } \\
\text { or adaptation of No.1 Courtroom. } \\
\text { - Resource Consent application } \\
\text { may be unsuccessful or if } \\
\text { successful may be appealed. } \\
\text { - HPT could make application for a } \\
\text { Heritage Order to protect the } \\
\text { interior of the building. } \\
\text { - Demolition may be considered in } \\
\text { conflict with the government's } \\
\text { 'Policy for Government } \\
\text { Departments' Management of } \\
\text { Historic Heritage'. } \\
\text { - Entry from Stout Street may not } \\
\text { satisfy requirements of Ministry } \\
\text { for the Environment's draft Urban } \\
\text { Design Protocol. } \\
\text { - Public amenity of Park space } \\
\text { could be largely retained. }\end{array}$ \\
\hline $\begin{array}{l}\text { Option B } \\
\text { - Develop } \\
\text { Supreme Court } \\
\text { on OHCB and } \\
\text { adjoining park } \\
\text { site } \\
\text { - No demolition of } \\
\text { OHCB } \\
\text { - No.1 Courtroom } \\
\text { used } \\
\text { - Chamber }\end{array}$ & $\begin{array}{l}35-39 \\
\text { Months }\end{array}$ & $\begin{array}{l}\$ 32.7 \mathrm{M}- \\
\$ 43.7 \mathrm{M} \\
\$ 32.7 \mathrm{~m} \text { for } \\
\text { original } \\
\text { chamber } \\
\text { size } \\
\$ 35.7 \mathrm{~m} \text { for } \\
\text { larger } \\
\text { chambers } \\
\text { to include }\end{array}$ & $\begin{array}{l}\text { - Preserves and restores all of } \\
\text { OHCB. } \\
\text { - Single or double level building } \\
\text { addition. } \\
\text { - Entry from Stout Street or } \\
\text { Whitmore Street or both. } \\
\text { - Resource Consent required } \\
\text { but may be non notified. } \\
\text { - Resource consent not } \\
\text { required for interior } \\
\text { alterations. }\end{array}$ & $\begin{array}{l}\text { - Judiciary consider No.1 } \\
\text { Courtroom to be inadequate. } \\
\text { - HPT not supportive of necessary } \\
\text { adaptation of No.1 Courtroom. } \\
\text { - HPT could make application for } \\
\text { Heritage Order to protect the } \\
\text { interior of the building but } \\
\text { considered unlikely to be } \\
\text { successful if owner objects. } \\
\text { - An increased chamber addition } \\
\text { (up to 900m2) could satisfy } \\
\text { Judicial requirements for clerks }\end{array}$ \\
\hline
\end{tabular}









\begin{tabular}{|c|c|c|c|c|}
\hline $\begin{array}{l}\text { Option D } \\
\text { - Develop } \\
\text { Supreme Court } \\
\text { on adjoining park } \\
\text { site } \\
\text { - Completely } \\
\text { restore OHCB } \\
\text { - Two buildings not } \\
\text { connected } \\
\text { - Provide a new } \\
\text { SC court } \\
\text { chamber in new } \\
\text { building } \\
\text { - Provide for the } \\
\text { library in the new } \\
\text { building } \\
\text { - All other } \\
\text { functions in new } \\
\text { Building including } \\
\text { CJ Administration } \\
\text { Staff. }\end{array}$ & $\begin{array}{l}32-36 \\
\text { Months }\end{array}$ & $\begin{array}{l}\$ 53.4 M \\
\text { Cost } \\
\text { attributed to } \\
\text { Supreme } \\
\text { Court is } \\
\$ 34.8 \\
\text { Cost } \\
\text { attributed to } \\
\text { restoration is } \\
\$ 18.6\end{array}$ & $\begin{array}{l}\text { - Preserves all of OHCB. } \\
\text { - Uses all of the park site. } \\
\text { - A three level building is likely } \\
\text { to be developed. } \\
\text { - Entry from Lambton Quay or } \\
\text { Whitmore Street. } \\
\text { - Resource Consent required } \\
\text { for effects on Heritage Values } \\
\text { of OHCB on neighbouring } \\
\text { site. May be to be non } \\
\text { notified. } \\
\text { - Allows purpose built design to } \\
\text { best meet functional needs } \\
\text { i.e. no compromise for } \\
\text { heritage values. } \\
\text { - Allows for full library in } \\
\text { located in same area. } \\
\text { Development comprises: } \\
2400 m^{2} \text { OHCB to be } \\
\text { 'restored' } \\
800 \mathrm{~m}^{2} \text { basement carpark } \\
\text { - } 3000 \mathrm{~m}^{2} \text { of office/court/library } \\
\text { space }\end{array}$ & $\begin{array}{l}\text { - All Supreme Court functional } \\
\text { requirements could be met. } \\
\text { - Judiciary is supportive of this } \\
\text { option. } \\
\text { - HPT have conditional supportive. } \\
\text { - The government's 'Policy for } \\
\text { Government Departments' } \\
\text { Managernent of Historic Heritage' } \\
\text { would be met. } \\
\text { - OHCB could be used for other } \\
\text { judicial purposes. } \\
\text { Potential for entry from Lambton } \\
\text { Quay or Whitmore Street may } \\
\text { better meet requirements of } \\
\text { Ministry for the Environment's } \\
\text { draft Urban Design Protocol. } \\
\text { - Potential for public access to the } \\
\text { prime heritage spaces of the } \\
\text { OHCB will be enhanced. } \\
\text { - Provides improved privacy and } \\
\text { security to Chambers due to } \\
\text { elevated location. } \\
\text { - Loss of park amenity for public } \\
\text { although building could be sited } \\
\text { in landscaped surroundings. }\end{array}$ \\
\hline
\end{tabular}

\section{Background}

15. The background to the presentation of this paper to the Committee is detailed in appendix 2. The appendix sets out a history and chronology of the development of option papers and records feedback from the Judiciary and the Historic Places Trust.

16. As a result of liaison and mediation with the Trust and judicial feedback, a paper was presented to the Committee in November 2004, which detailed issues that had arisen and sought direction as to how to proceed with the project.

17. To further consider an appropriate direction, the Committee requested proposals incorporating the utilisation of the adjoining park space and consideration of a purpose built court chamber on the park.

18. This paper responds to that request. 


\section{Design Options}

19. For each option outlined in paragraphs 10 and 11, there are a number of design parameters that define the option proposed. These parameters are summarised in the 'Options Summary and Comparative Assessment Table' and are set out in more detail in appendix 3.

\section{Further Consultation}

20. Since November 2004 further consultation has taken place. In considering the design options outlined above, the following feedback should be noted.

\section{Historic Places Trust}

21. Mediation with the Historic Places Trust determined that:

- The Trust did not support the demolition of any of the $\mathrm{OHCB}$ including the building additions (except the two level annex building constructed in the 1980 s and located at the western boundary of the OHCB site);

- The Trust prefers the adjoining park site be made available for the creation of a building necessary to provide for the Supreme Court functional requirements and that the $\mathrm{OHCB}$ (is restored without loss of heritage fabric; and

- The Trust had concerns as to the impact on the heritage fabric of the No.1 Courtroom as a result of the changes proposed to the No.1 Courtroom to meet the Supreme Count requirements. The No.1 Courtroom has a jury count layout with the bench accommodating only one Judge. Some furniture and fittings would need to be removed from the courtroom and the bench expanded to accommodate five Judges to meet an appellate court layout.

22. As the Trust's view in respect of the external façade was known, in April 2005, the Trust was asked to provide a clear decision on their support or otherwise for the proposed adaptation of the No.1 Courtroom necessary for the supreme Court functional requirements (as known as of end 2004). The Trust advised in a letter of 28 April 2005 that:

- Whilst some alterations and removal of furniture and fittings may be considered appropriate, the extent of change proposed for the Supreme Court is not supported;

- If alterations are required, their preference is for the Supreme Court to be located on the park; and that

- They provide this decision based on an understanding that the OHCB and the No.1 Courtroom are to be completely restored and available for other or ceremonial uses. 
23. In August 2005, the Trust was requested to provide consideration of the beneficial outcome of option $\mathrm{C}$ and their position on a resource consent application for Options A, B C \& D.

- The Trust gave conditional support to Option C. However they have concerns with the proposed scope of demolition incorporating the original chambers.

- Trust would be supportive of a reduced scope of demolition that retains the original 1881 Chambers and façade at the rear of the building and includes the demolition of the 1907 addition to Balance St elevation and the 1913 addition to Whitmore Street elevation. The Trust has indicated that it is prepared to accept demolition to these parts of the building in order to achieve other conservation and design outcomes, particularly the reduced height and bulk of the proposed addition.

The Trust was supportive of the provision of a new Count Chamber for the Supreme Court and restoration of the No1 Court room in its original configuration.

- The Trust opposes Option's A or B due to the level of alteration necessary to the No1 Court Room.

- The Trust gives conditional support for Option D but had concerns in regard the height of a three level building and prefer a less dominant scale to the building, that is, say two levels.

- The Trust's preference is that any Resource Consent application is processed as a Notified Resource Consent by the Wellington City Council.

\section{Judiciary}

24. Further consultation has also been undertaken with the Supreme Court Judiciary in order to obtain design guidance in light of the experience the Judiciary has gained from the operation of the Supreme Court. The following key comments were provided:

- Extra width to the judges' bench is preferable. Note that the current bench in the temporary Supreme Court is approximately $300 \mathrm{~mm}$ wider than what can be created in the No.1 Courtroom of the OHCB;

- Public seating capacity of thirty seats (as currently provided and as proposed for the No.1 Courtroom in the OHCB) is inadequate. The option for the provision of a lift to access twenty additional seats on the Public Gallery in the OHCB (which would have limited views of the Court) would 
still be considered inadequate. A target of one hundred seats (or near to this) should be considered;

- The press should be provided with dedicated seating providing a view of proceedings and facilities to enable the preparation of notes;

- A media broadcast room and media interview room should be provided;

- It is felt that the use of the No.1 Courtroom in the OHCB will enforce compromise sufficient to likely require the establishment of a larger new court room in the future;

- From experience in the temporary chambers where clerks are tocated together and away from the Judges, it would be preferable to have the clerks co-located with the Judges and Associates. If additional space is to be made available on the adjoining park site, then the judicial che

- A preference for the Chief Justice's Administration Staff to be located relatively close to the Chief Justice.

- The library facility should be capable of providing 2,500 linear metres to accommodate an appropriate Supreme Court Library collection; and

- The revised design Option 1 is not considered appropriate as it requires too many compromises and will fail to meet the functional needs.

- In respect of the current options being considered that propose the construetion of a new building, consideration should be given to the housing of a National Law Library within the new building.

\section{Ministry for the Environment}

25. The Ministry for the Environment has provided the following key comments:

The Government has published the draft New Zealand Urban Design Protocol and has made a commitment to provide government leadership in ensuring high quality urban design. The Supreme Court Project is a great opportunity to be an example of high quality urban design;

- A wealth of knowledge on sustainable building is available and should be made an integral part of the project. The greatest opportunities to maximise the sustainability of a building occur at the design stage; 
- The Ministry for the Environment recommends that urban design and sustainable building are made core components of this project. In
particular, the following should be addressed:

- Consideration of the placement of the main public entrance in a highly visible location that accords with natural pedestrian movement patterns part of the design concepts; and a public space should be an integral

- The need to consider the rand street frontages, including extionship of the proposed building to all at the ground floor to ing externalising active uses on street frontages design, with thesign concept will aim to achieve high quality urban building for the government the Supreme Court building be an exemplar Urban Design Protocol.

\section{Implications arising from Consultation}

26. This recent consultation has the following implications for the Supreme Court:

\section{Use of the OHCB}

27. If the No. 1 courtroom was to be used, the proposed alterations to the No.1
Courtroom for use by the Supreme Court will not be supported by the Trust.

28. The Judiciary consider the No. 1 Courtroom insufficient to meet their long term needs in regards to the:

- Size of the bench;

- Public seating capacity; and

- Miedía access.

29. The T

façade at th not supportive of the demolition of the original chambers and historic additions on whitmilding. They are supportive of the demolition of the additions will enable the new and Balance Street. The removal of the historic were retained. Retaining the addition to sit closer to the OHCB than if they use of the chambers rooms as part chambers may provide opportunity for buildings.

30. As well as the No.1 Courtroom, the Judiciary consider the rest of the $\mathrm{OHCB}$ especially in respect of the library and clerk space and also to meet the Administration staff. 


\section{Use of Park}

31. Both the Judiciary and the Trust consider utilising the park space to build a purpose built Supreme Court as a preferable option.

32. The Trust has expressed this preference on the basis that the OKCB is fully restored and any new building is sympathetic and complimentary to the $\mathrm{OHCB}$.

33. Removing the Supreme Court courtroom from the $\mathrm{OHCB}$ will remove the focus from the OHCB in respect of the Supreme Count and as a consequence the new building and not the OHCB will be identified as the Supreme Court.

\section{Design Implications arising from Consultation}

34. To satisfy the Trust's preferences, the following key parameters would need to be incorporated into a design solution:

- Reduced demolition of the OHCB to retain the original chambers at the rear of the building.

- The No.1 Courtroom would be restored in its historic arrangement and in so doing, would not meet the requirements for the Supreme Court.

- The OHCB will be fully restored including all areas that have no functional use for the Supreme Count.

- The park site will be utilised for construction of a new court chamber, judges' chambers and other support facilities.

The Trust preferences are best provided by a modified Option $\mathrm{C}$.

35. To satisfy judicial preferences, the following key parameters would need to be incorporated into a design solution:

A new purpose built court chamber is required of a size approximately $50 \%$ larger than the No.1 Courtroom.

- The new build chambers area would be increased to accommodate all judicial support staff within the Judicial Chambers suite.

- The area required for Library would increase from that currently planned under revised option 1.

- The accommodation of the Chief Justices Administrative Staff in the new addition. 


\section{The Judicial preferences are best provided by options C \& D.}

36. To satisfy the preferences of the Ministry for the Environment, the following key parameters would need to be implemented into a design solution:

- The principals of the draft New Zealand Urban Design Protocolare adhered to.

- The Principal of sustainable building design are adhered to.

- The main public entry from either Whitmore Street or Lambton Quay.

- Public spaces will be provided.

The Ministry for the Environment preferences are best provided by options C or D.

\section{Regulatory Compliance}

37. The Resource consent required for the alterations of the OHCB will be assessed and issued by the Wellington City Council (WCC). The Trust is identified as an effected party. They have no regulatory control but their views will be considered by the WCC.

38. Demolition is a restricted discretionary activity and any demolition will require a notified resource consent, which can either be approved or denied by the WCC either with or without the Trust's support. Decisions on notified resource consents can be appealed to the Environment Court by the applicant and submitters.

39. The adaptation of the No.1 Courtroom requires no regulatory approval as the WeC listing of the OHCB identifies the external façade only, that is, alterations to the No. 1 Courtroom are able to be done as of right under the current WCG District Plan criteria.

40. The Trust could apply for a Heritage Order from the Environment Court if they foresee a significant threat to the building's heritage values. The Environment Court would consider the impact on the owners rights resulting from such an order. If an order was granted, no alterations could be done without the approval of the Trust.

41. It should be noted that the WCC has issued notice on the Ministry of Justice (under section 66 of the Building Act) to either strengthen or demolish the $\mathrm{OHCB}$ as it is identified as a public risk. Demolition would require a notified resource consent and is unlikely to be approved. The Ministry of Justice will be required to strengthen the building irrespective of the outcome of the Supreme Court project. 


\section{Consultation}

42. The Historic Places Trust has been made aware of the options contained in this paper and expressed their opinion in respect of these options. The Trust has been involved with detailed consultation in respect of Option A.

43. The contents of this paper have been shared with the departmental accommodation committee led by the Ministry for the Environment. This committee included the State Series Commission, who have noted the Commission does not have a direct interest in the accommodation forthe Supreme Court.

44. Treasury have reviewed this paper and have provided the following comments:

- In Budget 2003, Ministers were invited to consider four options with differing cost and functionality profiles. These ranged in net cost from $\$ 13.7 \mathrm{~m}$ to $\$ 22.6 \mathrm{~m}$ (GST excl). A decision was made to develop the old Wellington High Court building and to refain (rather than develop) the rest of the Crown owned site as a park, at a net cost of around $\$ 19.5 \mathrm{~m}$.

- Following consultation with the Judiciary and Historic Places Trust, the project options have changed significantly to accommodate their requests. While consultation with the Judiciary and Historic Places Trust is important, the Supreme court facility is a significant public building and stakeholder views must be balanced with wider government objectives and comprercial considerations.

Treasury supports the narrowing of scope to avoid unnecessary delay and consultant costs. However, as currently worded this paper invites ministers to choose an option to proceed with, but does not provide sufficientinformation or any evaluation criteria to enable such a decision to bevmade.

We do not support narrowing the scope of the options until all relevant comparative information is available for Ministers. We therefore believe that Ministers should direct the Ministry of Justice to further develop all current concepts for a later decision.

45. Ministry for Culture and Heritage have reviewed this paper and have provided the following comments:

- Wellington's Old High Court building is registered as a Category I historic place under the Historic Places Act 1993, meaning that it is a building of 'special or outstanding historical or cultural heritage significance or value'. 
It has suffered deferred maintenance over a number of years, and the Historic Places Trust and the heritage community have expressed concern at its deteriorating condition.

- In August 2004 the government adopted a 'Policy for Government Departments' Management of Historic Heritage' (POL Min(04) 19/1 refers). Key requirements of this policy include:

- historic heritage practice involves the least possible alteration or loss of material of historic heritage value;

- government departments will care for their places of historic heritage value by monitoring their condition, maintaining them, and, where required, repairing them; and

- government departments will ensure that their places of historic heritage value in active use are managed in such a way that:

- they retain, where appropriate, an ongoing function in the life of the community compatible with their beritage values;

- the continuation of original or long-term uses is strongly encouraged; and

- they are not disposed of without fully exploring options for their reuse for alternative compatible uses.

- Assessed in terms of these policy settings, both options A and C are unacceptable as they involve the demolition of a significant amount of heritage fabric. Options $B$ and $D$ avoid much or all loss of exterior heritage fabric, inchuding the historic 1907 and 1913 additions to the building.

- While option B would ensure that that the building has a strong association with the Supreme Court, this is achieved at the expense of the heritage fabric of the No. 1 courtroom, some of which would be removed or altered in order to meet the functional requirements of the Court.

- On this analysis, option $D$ is therefore the more acceptable as it ensures that the building will be fully restored in line with the requirements of the Policy for Government Departments' Management of Historic Heritage'. This includes the conservation of the historic 1907 and 1913 additions to the building, and their re-use.

- The Ministry notes that in its initial assessment the Historic Places Trust found that no demolition of the exterior heritage fabric of the building was acceptable, including the 1913 and 1907 additions. Following a fresh assessment of the options presented in this paper, the Historic Places Trust has now, however, changed its position. In its revised assessment, the Trust accepts some demolition in the interests of, among other matters, reducing the bulk and height of the proposed addition on the park. On this basis, the Trust's preferred option is a modified option C, which 
retains the 1881 Judges' Chambers and facade, restricting demolition to the 1913 addition, and a part of the 1907 additions.

- The Ministry considers that there is likely to be a range of views amongst heritage professionals on whether any demolition of the exterior heritage fabric is acceptable and, if so, the extent of demolition which should be permitted in the wider interests of the project.

- If option $D$ is not advanced, only the modified Option $C$ advocated by the Historic Places Trust (which involves considerably less demolition than the option $\mathrm{C}$ presented in this paper) could be justified in light of the Rolicy. In both cases, it will be important that ongoing uses are found for the old High Court building which is compatible with its historical use as a court. This need is accentuated with respect to option D, as itinvolves the construction of an entirely separate building for the supreme Court.

- Whichever option is agreed, it will be important to ensure that the new building on the park site is compatibje in design and height with the existing Old High Court building, Furthermore, in order to ensure that this project is implemented to best practice standards, it is necessary that there is ongoing consultation with the Historie Places Trust on detailed design and conservation issues.

\section{Process Moving Forward and Timetrames for Design Completion}

46. If a decision to proceed under one of the design options is made, the key tasks to advance the project to a stage where a design concept can be presented are as follows:

Update the project's Terms of Reference;

Establish reporting procedures with the Ministerial oversight committee;

- Confirm project governance arrangements;

Confirm design parameters;

Develop the design brief following further consultation and in line with the new design parameters;

Obtain approvals for the design brief;

- $\quad$ - $\quad$ Consultation and selection of a preferred option with the input of the judiciary and other key stakeholders for approval by the project Governance Committee and Ministerial oversight group;

- $\quad$ Preparation of a preliminary cost estimate for the project;

- Preparation of the project programme to determine timeframes;

- Consultation with Historic Places Trust and other interested parties; and

- $\quad$ Report to Cabinet with recommendations for a design concept with associated costs and timeframe for completion. 
47. It is estimated that this process would take four to six months from the time of approval of a preferred option and design direction.

\section{Recommendations}

48. It is recommended that the Committee:

1. Confirm that the adjacent park site is able to be incorporated into the Supreme Court project and available for use as part of the Supreme Court design options if required.

2. Direct the Ministry of Justice to develop design concepts based on the design option or options of:

A. Utilising the $\mathrm{OHCB}$ and No. 1 Courtroom with partial demolition of the rear of the $\mathrm{OHCB}$ and construct a chamber addition which minimises intrusion into the adjoining park site with an indicative cost range of $\$ 30 \mathrm{~m}$ to $\$ 41 \mathrm{~m}$ depending on how functional requirements can best be met;

\section{And/Or}

B. Utilising the $\mathrm{OHCB}$ and No. 1 Courtroom without any demolition and construct a chamber addition which encroaches further into or uses the adjoining park site with an indicative cost range of $\$ 32.7 \mathrm{~m}$ to $\$ 43.7 \mathrm{~m}$ depending on how functional requirements can best be met;

\section{And/Or}

c. Construct a large new build addition for the Supreme Court incorporating judicial chambers, the court chamber and library on the park site, restore the OHCB with the exception of the area at the rear of the building which will involve some demolition and restore the No.1 courtroom without major alteration which can then be utilised as a working court by other jurisdictions and for ceremonial purposes. This option has an indicative cost for the new building and restoration of the majority of the OHCB of $\$ 49.7 \mathrm{~m}$;

\section{And/Or}

D. Construct a separate building for the Supreme Court incorporating all the Supreme Court on the park site, fully restore the $\mathrm{OHCB}$ and make use of the OHCB by other jurisdictions and for ceremonial purposes with an indicative cost for the new build and restoration of $\$ 53.4 \mathrm{~m}$. 
3 Note that the Ministry of Justice will consult with Judiciary, the Historic Places Trust, Ministry for Culture and Heritage and the Ministry for the Environment in the development of design concepts in respect of the selected option or options.

4 Invite the Minister for Courts to report back to the Committee with developed design concepts including associated costs and timeframe

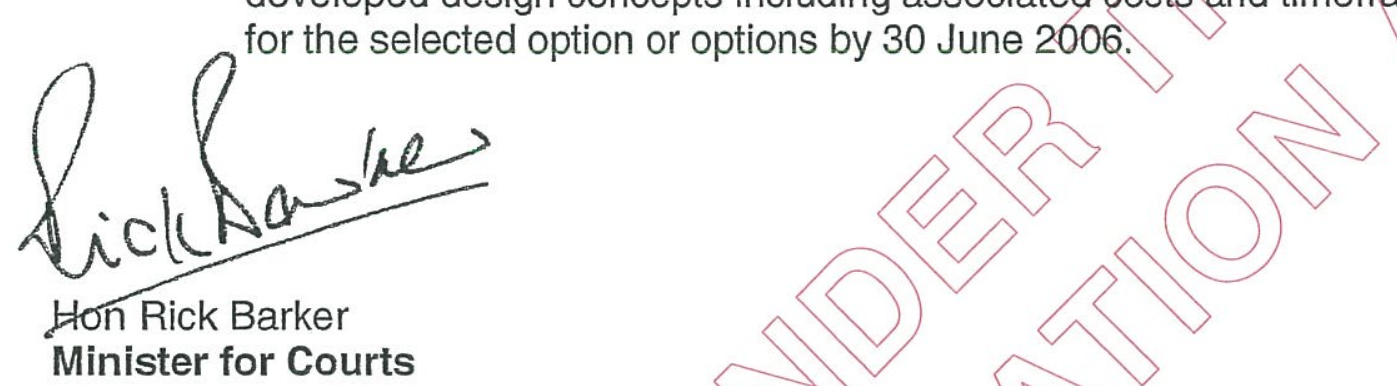
Minister for Courts 


\section{Appendix 1}

\section{Options Summary and Comparative Assessment Table}

\section{Assumptions for Assessment of Design Options}

1. A preliminary assessment has been undertaken in regard to indicative duration times, cost, an outline of the parameters and issues associated with each option.

2. The costs have been calculated utilising information developed for the current design Option A (Option 1 revised) and the indicative area assessments. It is therefore important to note they should be used only for the purposes of comparative evaluation of the different options and must not be considered a robust costing for any one of the options. Allowance for ipcrease in construction costs has been included assuming a $5 \%$ per annum ongoing escalation.

3. Indicative durations have been assessed assuming resource consents are obtained without appear and assume commencement at the point the project terms of reference and key parameters are agreed. These timelines are provided for comparative purposes and have been developed without reference to any actual design (other than option A). Considerable risk is carried in the initial design and approvals phase of the options.

4. It is intended that accurate cost estimate and timefames would be developed foran actual design solution once a development / design preference is identified. Until this is completed, there is considerable risk in the accuracy of this information. 


\section{Appendix 2}

\section{Background}

1. Background to the development of options in respect of the permanent premises for the Supreme Court and in particular liaison with the Historic Places Trust is set out below.

2. The former $\mathrm{OHCB}$ is registered as a Category 1 historic place under the Historic Places Act 1993. This means that the buliding is regarded as having 'special or outstanding historical or cultural heritage significance or value' in terms of that Act. In addition, the exterior of the building is listed on the Wellington City Council District Plan, and is subject to heritage controls under that plan.

3. Cabinet has previously agreed to the development of permanent accommodation for the Supreme court on the basis of a design option ("option 1") involving redevelopment of the OHCB at a cost of $\$ 19.25$ million. [CAB Min (03) 13/9(14) and CAB Min (03) 41/4A].

4. Since then, consultation with the Judiciary has clarified the functional requirements for the Supreme Court. It has become evident that option 1 as originally agreed would not neet the functional requirements for the new Court. Âs a consequence, the Ministry explored refinements to the option 1 design to better address these requirements.

5. The government has adopted a best practice 'Policy for Government Departments' Management of Historic Heritage'. All government departments are required to adhere to this policy, and to develop guidelines for its implementation in consultation with, and with the assistance of, the Ministry for Culture and Heritage. Among other matters, the policy establishes the principle that 'Historic heritage practice involves the least possible alteration or loss of material of historic heritage value'.

6. In April 2004, a refined option 1 design was developed that met most of the Court's functional requirements. In developing the revised design (as well as the original design) the Ministry adopted an approach to preserve as much of the heritage values of the OHCB as possible. However, in revised option 1 as in the original option 1, some amount of demolition was proposed (12\% of the exterior wall area). This demolition would however, allow the remainder of the exterior facade to remain intact and the interior spaces to retain their original subdivision layouts which minimises any alterations. This level of demolition was required with both options to enable the design to meet the constraint of not encroaching into the park space.

7. Consultation occurred with the Historic Places Trust regarding the revised design concept. The Trust expressed concerns in respect of the proposed 
removal of part of the original rear of the building and two of the later additions, necessary under the revised design concept to cater for the Judges Chambers addition. It should be noted that a similar amount of demolition was also proposed under the original option 1 design.

8. At the time, the Trust did not accept that any demolition needed to take placeand believed that there were alternative options for the placement of the chambers. They proposed that an alternative design be developed that would ensure that the existing building remains intact. The Trust further argued that the design for the Supreme Court should not be constrained by the existing use of the adjacent park facing onto Lambtor Quay and owned by the Ministry.

9. The Trust questioned the requirement for the park to remain, viewing the park area as a potential site to either completely house a new ludges chambers building or to allow the proposed addition to adjoin the existing building.

10. The Park site was created in the 1990's when the former Magistrate's Court and a Police Station were demolished and the site became vacant.

11. At the suggestion of the Minister for Arts, Culture and Heritage, a mediation session was facilitated between the Ministry and the Trust. The outcome of the mediation was the joint commissioning of an independent Assessment of Effects report by a Conservation Architect. An Assessment of Effects considers the impact that the proposed design/alterations will have on the heritage values of a building. The assessment is done with reference to international conservation and heritage practice charters, Wellington City Council district plan criteria and the current project brief and constraints.

12. The Ministry had previously commissioned an Assessment of Effects report which acknowledged that the proposed alterations would have negative and positive effects on the heritage values of the building, but concluded that on balance, the benefits outweighed the drawbacks and the proposed design would enhance the heritage values and extend the life of the building.

13. The conclusion of the second independent Assessment of Effects report was to support the findings of the earlier assessment commissioned by the Ministry. The second Conservation Architect stated that the new addition to the building had been skillfully planned to serve judicial needs while preserving those elements of the building that have the greatest heritage significance. The report also acknowledged that there would be some loss of heritage value but commented that the assessment had been considered from the point of view of best practice building heritage conservation.

14. At the conclusion of the mediation, the Historic Places Trust did not agree with either assessment, stating that accepting the removal of parts of the building cannot be regarded as best practice building heritage conservation. 
15. A paper was prepared and presented to the Committee in November 2004 which detailed the issues that had arisen from consultation with the Historic Places Trust and sought direction as to how to proceed with the project.

16. To further consider an appropriate direction, the Committee requested proposals incorporating the utilisation of the adjoining park space and consideration of a purpose built court chamber on the parkspace. 


\section{Appendix 3}

\section{Design Options}

For each option, there are a number of design parameters that define the option proposed.

1. Option A Utilise the OHCB and No.1 Courtroom with partial demolition and construct a chamber addition which minimises intrusion into the adjoining park site

Parameters:

- Establishes the Supreme Court largely on the OHCB site;

- Partial demolition of historic additions and original chambers which are unsuitable for use by the Supreme Court;

- Full restoration of the remaining OHCB $(2,700 \mathrm{~m} 2)$ with full functional use by the Supreme Court;

- No 1 Court room used for Supreme Court;

- Entry to building from Stout Street;

- Ground level addition required for new purpose built chambers of $650 \mathrm{~m} 2$;

- Chambers could be expanded to provide accommodation for Judicial clerks to be co-located with Judges. This would give a total ground level addition of $900 \mathrm{m2}$;

- Additional library space could be provided from space in the OHCB earmarked for clerk accommodation if clerks were accommodated in chambers; or

A second level could be added to the chamber addition to provide space for the library to be located together and/or provide for future growth.

2. Option B Vtilise the OHCB and No.1 Courtroom without any demolition and construct a chamber addition which encroaches further into or uses the adjoining park site

Parameters:

- Establishes the Supreme Court on the OHCB site and the adjoining park site;

- No demolition of the OHCB;

- Full restoration of all the $\mathrm{OHCB}(2,400 \mathrm{~m} 2)$ including areas not required for Supreme Court usage;

- No1 Court room used for Supreme Court;

- Entry from Stout Street or Whitmore Street or both;

- Ground level addition required for purpose built chambers of $700 \mathrm{~m} 2$. This is greater than under option $A$ to provide for additional space to connect the two buildings; 
- Chambers could be expanded to provide accommodation for Judicial clerks to be co-located with Judges. This would give a total ground level addition of $900 \mathrm{~m} 2$;

- Additional space for library could be provided from clerk space in OHCB and additional space as a result of no demolition; or

- A second level could be added to the chamber addition to provide space for library to be located together.

3. Option C Construct a large new build addition utilising the park space and linked to the OHCB with partial demolition of the rear of the OHCB, to house judicial chambers and court chamber and ancillary functions.

Parameters:

- Supreme Court established on the adjoining park site;

- Construct a new purpose-built twolevel addition to house expanded judicial chambers to co-locate clerks, expanded court chamber to meet needs, library and ancillary functions $(2,260 \mathrm{~m} 2)$ or a further expansion to accommodate Chief Justice Administrative Support Staff (2400m2);

- Entry from Lambton Quay or Whitmore Street;

- No1 Court room not used for Supreme Court but used by other jurisdictions;

- Partial demolition of historic additions and original chambers at the rear of the OHCB; and

- Full restoration of the renaining $\operatorname{OHCB}(2,100 \mathrm{~m} 2)$. No or limited functional use by the Supreme Court (for Conference facilities and could be utilised for Chief Justice Administration support staff depending on connections to new building) but could be utilised by other jurisdictions and for ceremonial purposes.

4. Option D Construet a separate building for the Supreme Court including the Court Chamber and Library on the park site and fully restore the OHCB for use by other judicial functions.

\section{Parameters:}

- Supreme Court established on the adjoining park site;

- No1 Court room not used for Supreme Court;

- Construct a new purpose-built two or three level addition to house expanded judicial chambers, expanded court chamber, library and ancillary functions $(3,000 \mathrm{~m} 2)$;

- Entry from Lambton Quay or Whitmore Street.

- No demolition of the OHCB; and

- OHCB fully restored $(2,400 \mathrm{~m} 2)$ with no functional use for the Supreme Court and used for other judicial purposes. 


\section{Supreme Court Permanent Premises Project}

\section{Option C (Modified) Parameters 6 April 2006}

The following notes set out a the key parameters for the design of the Supreme Court and restoration of the Old High Court Building as directed by Cabinet in March 2006 and as) further directed by Minister for Courts in March 2006.

These are high level parameters to provide direction to the Architect and Design Team setting out the parameters for the overall design. These key parameters are supported by a more detailed Premises Design Brief. The Premises Design Brief details functional requirements and space requirements to set deliverables for the design.

\section{$\underline{\text { Option C (Modified) }}$}

\section{Physical Parameters:}

- Involves demolition of the historic addition on Whitmore Street and part of the historic Balance Street addition. The original Judges Chambers are to be retained,

- Utilises the park site but allows for landscape 'buffer' to Lambton Quay.

- New building will be in the order of a $2400 \mathrm{~m} 2$ two level building (no higher than the existing $\mathrm{OHCB}$ ) with a basement car park.

- Access connection(s) is to be provided between the OHCB and the new building.

\section{Functional Parameters:}

- No1 courtroon in OHCB will not be utilised for the Supreme Court courtroom but will be considered for other Jurisdictions.

- The new addition will accommodate the main functional areas of the Supreme Court including:

- Judges chambers and support staff

- Courtrodm

Library

Registry

- Some Supreme Court functional use may be provided in the OHCB, possibly a Conference Room and associated functions and or the Chief Justice's Administrative support.

Time and Cost Parameters:

- Rough order of cost assessed as $\$ 49.7 \mathrm{M}$ (for original option $\mathrm{C}$ including removal of original chambers - modified option $\mathrm{C}$ requires addition restoration).

- Indicative duration of project 34 to 36 months. 


\section{Option C (Modified) Parameters 6 April 2006}

\section{Design Guidance:}

- The OHCB No1 court room is to be restored largely in its historic layout.

- The OHCB is to be fully strengthened and restored with a design life of 100 years.

- The OHCB is to be upgraded to provide high quality environmental control and full fitout of interior spaces.

- Main entry to the Supreme Court is to be from Lambton Quay.

- The design of the new building is to be befitting of the status of the supreme Court which it will house and should be substantive and enduring. The building is to be respectful to the historic OHCB but not a replication and will be of its own era.

- The design is to provide attractive landscaped surrounds to the Supreme Court and public amenity (seating) where appropriate.

Parameters Agreed by Governance Group

Sandi Beatie

Chair 


\section{$31297-014$ \\ P1 of 9}

\section{SUPREME COURT}

\section{Premises Brief Version 2 \\ 18 July 2006}

The following notes set out the brief for the design development for the Supreme Court (Old High Court Building).

It is intended this brief will be developed through consultation with key stakeholders in the period April 2006 to July 2006. A finalised version with sign off from stäkeholders will be submitted for final approval from the Project Steering Group.

\section{DESIGN GUIDE FOR THE SUPREME COURT OF NEWZZALAND}

\section{DRAFT March 2006}

\section{$1.0 \quad$ General}

\subsection{Exterior}

The building exterior should reflect the status of the Supreme Court as the repository of NZ law and the apex of the third arm of Government. The building should not be ostentatious.

\subsubsection{Security Considerations}

- $\quad$ All external glazing to achieve security pefformance of intrúder resistance level 2 of Ás strallan Standard A $\$ 35552003$

- $\quad$ All external windows, which open, must be secured.

- Environnowntal security to be considered in all landscaping.

- External fences must allow high visibility

- External security lightino to be discussed

1.2 Interior.

IDS to be included.

The interior design of the building must provide good lighting, acoustic contiol good environimental control and facilitate modern efficient work practices. Propose heating control range using existing methods and ESD type.

Collegiality, as we have discussed, is extremely important, particularly in a nerr court. The ailm should be to co-locate Judges to the greatest exterit. possib/e, so providing them with opportunity to work together rathe "than in silos."

See) Memorandum from the Chief Justice, Premises Brief Provisions, Q7.11.03 (paragraph 3 )

\begin{tabular}{|c|c|c|c|}
\hline & $>$ & $\begin{array}{l}\text { NO. OF } \\
\text { STAFF }\end{array}$ & $\begin{array}{r}\text { REQUIRED } \\
\text { AREA m2 } \\
\end{array}$ \\
\hline 2.0 & Registrar & & 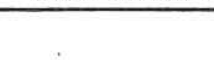 \\
\hline 2.1 & Registrar (office) Need to define location of office eg in OHCB & & 15.0 \\
\hline 2.2 & Meeting room (to adjoin Registrar's room) & & 20.0 \\
\hline 2.3 & $\begin{array}{l}\text { Allow for temporarily manned ( } 2 \text { person) sit down counter with a } \\
\text { waiting space for up to } 10 \text { persons }\end{array}$ & & 30.0 \\
\hline & Registrar Total & & 65.0 \\
\hline
\end{tabular}




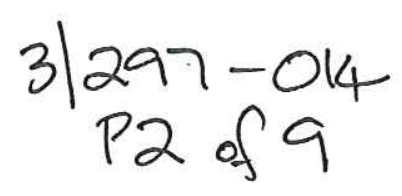

3.0 Public Accessible Area

3.1 Press room (temporarily occupied with up to 5)

- Clarify if this includes the TVIAV room. If so:

- Data cabled from Courtroom 1, with outputs for outside broadcast.

- Supply own equipment.

3.2 Security Office (Occasionally occupied with 1 person)

3.3 Public Foyer Area (Accommodates 35 people standing)

- The public foyer should be at least similar to the temporary court in Molesworth St, at $180 \mathrm{~m} 2$ to $200 \mathrm{~m} 2$.

- However, the foyer should reflect the nature of proceedings, and be inviting for the public, and legal/juidiciary.

- The purpose is to allow the public to see uustice being done.

- There will be view shafts through the courtion

- $\quad$ CCTV in Foyer with 21 inch screen in Admin area

- Power supply in foye for Walkthrough or otter security measures

- Provision also needs to be made for the in couttroom images \& sound of proceedings to be transmitted to locations outside of the courtroom i.e. public lobby or to an external location.

- Access doors to be discussed. Mag lock or nórtise.

- The public has a basic requirement in that they need to be able to see Justice being done \%o this end the ability to see and hear clearly all proceedings is yital.

- A sound system must provide a high quality audio level for all speech from Judges and coun nel.

- A large LCD screen (or similar) will be needed for the purpose of conveying imanges to the public gallery. This would service the need for both evidence display as well as video conferencing images.

A system (hearing loops of similar) providing sound for the hearing impaired is also a necessity.

3.4 Public Toilets M \& F

3.51 Disabled $>$ Toilet Unisex

Public Accessible Area Total 4.0 Registry

4.1 Court Officers w/station

- The registry may be located in the $\mathrm{OHCB}$, to allow for secure processing of claims, during times that court is not in session.

- Location in the OHCB allows for easy assess by the legal profession, and secure separation from the

\subsection{Admin Support w/station}




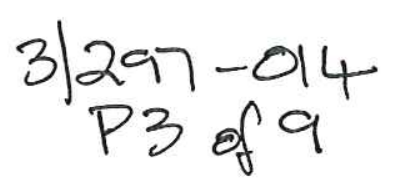

- $\quad 21$ inch screen in Admin area for CCTV located in Foyer

Shut down switch in Admin area located in area of Monitor. Must be lever type switch, in an easily accessible position and clearly labelled.

4.3 Finance Administrator

4.4 Growth w/station

4.5 Strong room

4.6 Store/File Room Lundia type (2hr F/R)

- $\quad$ File and records management system needs to be flexible for variable case files and provide a convenient and durable handling container. Shelving to be sized to suit file container.

- $\quad$ Case load for Supreme Court estínated as $50-80$ cases (approximately 700 heard at Couit of Appeal) although cases files will likely be large.

Both electronic and paper files will be required to suiti differing work practices

\subsection{Production room}

"With the advent of electronic filing, it is likely that the Registry. will have to extend its production of hard copy casebooks. This is an area of considerable activity and hoise and does, not lend itself into incorporation into other workspace"

See Memorandự from The Chief Justice premises Brief Provisions, 07.11 .03 (paragion $h$ 2.1)

\section{$4.8 \quad$ Fax (1)}

4.9 Printers (2)

4.10 Mail area

4.11 Coatcupboard

4.12 Cabinets rile (6)

4.13 Bookcase (2)

4.14\% Cablnet StorelStationery type (2)

4.15. Raper Recycle Bin.

5.0 Staff 2 acilities

interaction between Registry staff and Judicial support staff shoúld be fostered by provision of common staff facilities.

Staff and Counsel to have separate access from public. Staff to be provided with entry from both Whitmore and Balance Streets if possible.

- $\quad$ Access doors to be discussed. Mag lock or mortise.

\subsection{Tea-room/Training Room}

\subsection{Staff Toilets M\&F}

5.3 Uni-sex shower \& disabled toilet 
6.0 Courtroom Areas:

6.1 Courtroom 1

- $\quad$ Court room should provide seating for 30 public.

- $\quad$ Electronic display and video conference facility required in Court Room.

Transcripts will very rarely be required. If required EFTR system to be utilised. There must be a barrier between the public area and the body of the court. Barrier to include polycarbonate or the like to a ht of at least $1.7 \mathrm{~m}$. Construction similar to the barrier in Courtroom 1 Wellington $\mathrm{HC}$.

Corridor doors to the side of the Courtroom to have one way vision panels.

The ability to record via cameras is still in need of further discussions, as this will present a number of issues thot only for the Judiciary but also for the design team. However, there will be times when video or a visual recording of some type will be required for the news media. TV camerasin court can be distracting and the necessary cabling can be a hazard. We need to look at built-in facilities or the cuitilisation of the courts own camera recording network to provide footage of "in courtroom" activities to the media Provision also needs to be made for the "in courtroom" images \& sound of proceedings to be transmitted to locations outside of the courtroom i.e. public lobby or to an external locátion

A central lectern will be available for the presentation of oral submissions. This lectern will be connected to the sound system for projection of the voice as well as for digitial recording.

The requirement to provide an accurate record of all proceedings within the Courtroom was been taken one step further in Meetbourne with a visualuvideo recording as well as an audio récording.

The source to which these recordings are transported will mostly likely take the form of a digital recororing system with the ability by the Judiciary to access the se recordings with ease.

Io Victoria Aưstrallia courtroom evidence recording is transcribed by way of a remote transcription centre located in Melbourne and the transcribed data is then sent back to the courtroom. The information Will also be required on line at a later date by the Judge or others when reviewing the evidence/case in Chambers.

This may mean a software solution that is accessible via the chambers equioment that allows for instant playback of a varticular case ${ }^{\text {no }}$ part or whole if required.

The audio recordings are normally captured by means of microphones placed on the bench, counsel desks with cabling leading back to a basic recording and sound rack controlled by the Court Taker.

These microphones also have a mute button attached to them for personal activation as the situation may require.

In overseas operations cameras were dispersed throughout the Courtroom in at least 5 positions.

These cameras record the proceedings of the Court and are used at the discretion of the Judge. Again either the Judge or the court-taker can control these.

There was also a separate camera usually on or near the Courttakers bench for the screening of evidence both written and physical for record purposes and for playing back on screen 


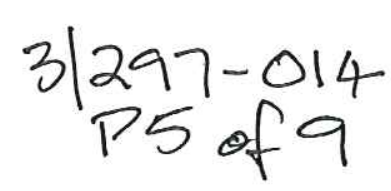

within the courtroom for all to see.

The Courts in which these existing systems were viewed were Jury Trial Courts, District and Youth \& Family courtrooms - not Appellant Courts and therefore there maybe some differing needs for the appellant courts that are not readily apparent when looking at recording images.

Their cameras record the Jury, Dock and Witness Stand, a wide angle of the Courtroom and Public seating as well as the Judge (s) on the bench.

The Supreme Court will not have a Jury, Dock or Witness Stand - so the overall requirement for cameras may reduce accordingly.

Such wholesale fulltime recording - particularly with one camera solely focused on the bench - may not be deemed necessary or appropriate in this Appellant Court.

However a visual (Digital?) record to accompany the audio recording is desired, with control to allow flexible wsange and some means of indication when each camera is operating.

The final position of the cameras will be dependent upon direct comment from the Judiciary as to whether or not certain recorded angles are considered necessary

\subsubsection{Bench}

Bench to be set at low level so that eye height when seated matches standing Counsel. Bench to seat seven Judges with approximately $1.5 \mathrm{~m}$ work space each Computer. screen and keyboard to be integrated into bench to allow for both paper based and electronic work practices storage for case files to be provided behind bench and on mobile trolleys.

Judges bench must go wall to wall Duress activators 1 per Judge to be positioned on the privacy panel of the bench. Müst be lever type ańd labelled.

- Whilst seated at the bench the Judiciary Will require access to services including those already avalilable in chambers, such as, the secure Judicial server, electronic law library and the Internet as well $/$ s the other standard operating functions and software packages

A screen keyboard and PC should be provided for each Jüdge. All systems available for access by Judges within their Chavibers should be provided at the bench. An integrated hardware solution should be developed avoiding the need for laptop use.

The positioning of the screens and keyboards should not compromise the use of the bench for paper layout etc. The hardware should be able to be largely concealed if the Judges elect not to utilise it and should not be a hindrance to their use of the bench screen location must not impede view lines between Judges and Counsel.

The use of in bench display units was prevalent in the overseas examples,

These screens for displaying the information available on normal top mounted computer screens and corresponding hard drives were built into the bench design and mounted at a low angle.

Some examples had these screens mounted beneath the flat surface level of the bench itself with the surface of the bench at this point being glass.

The screens we witnessed in Melbourne were approximately 15 -17 inch monitors.

These screens did not display any of the video fed displays such as out sourced video links or evidence displays. These 


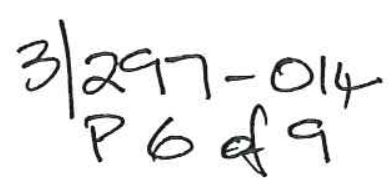

functions were catered for an additional TV screen, which took up valuable bench space.

The ability to incorporate within the screen the function of a split screen to display not only word documentation but also evidence display or a separate video feed from an outside or pre recorded source is desirable. In the Melbourne County Court the controls for all technology were by way of a "touch screen" mounted on the Court-takers bench.

The control of this display function may remain with the Judges or be left to the operating skills of the Court taker

The supply of additional power points and computer jack points to the bench is a standard requirement.

\subsubsection{Councel Desks}

Counsel desks should be flexible to allow for relocation to cope with up to 20 Counsel. Desks should include novable lectern and be fully wired for IT access.

Counsel will be required to be seated at the tables provided starting at a distance of approximately $5.5 \mathrm{~m}$ from the bench.

Counsel will also need to have external hite met access to their own Law Library and other material suich as their electronic database. It is not envisaged that Mol will provide PC's/Monitors for Counsel.

- $\quad$ Counsel will also require a clear line of sight to a visual display unit that may be needed to assist during the presentation to the Judiciary.This may take the form of either large L $Q D$ (or similar) type screens mounted in füll view and in close poximity to the Counsel table. As a preference this screen should also provide display for video conferencing (if requíred) and be a permanent fixture integrated into the design of the Courfoom.

Within the tables there will need to be IT \& power outlets for connection purtoses that will enable yaptops to be used to project their inages, via the Court Taker; onto the display units available

\subsubsection{Press Bench}

Press bench to cater for 6 and facilities for television coverago within Court room

The press and media must have at the very least the ability to

$\bullet$ record via hand witten notes, the proceedings of the day.

\section{1 .4} count Taker

Court taker will require desk with audio controls etc.

The court taker will be responsible for the set up and running of the daily requirements of the Supreme Court.

The ability to control the images, sound, evidence recording and the like displayed on whatever the developed final de sign solution is, will remain with the Court-taker. It is envisaged that as many as possible of the sound and visual aids available will be pre set and not require any adjustment at all. A touch screen or similar control panel would be envisaged. This may take the form of being able to place something such as a document or transparency on a display unit and project that to a number of screens for visual access by all interested parties.. It may also include the need to display audio/visual feeds from a static source such as a DVD or from a laptop as well as transmit to the viewing screen an image being beamed in from an outside source. The controls should be kept to a minimal size as the space available is very limited and the ideal location for such supporting hardware would ideally be outside the area of the Courtroom.

- $\quad$ The lighting to the Courtroom will also be preset to suit the VDU hardware but controls will be provided at the Court takers

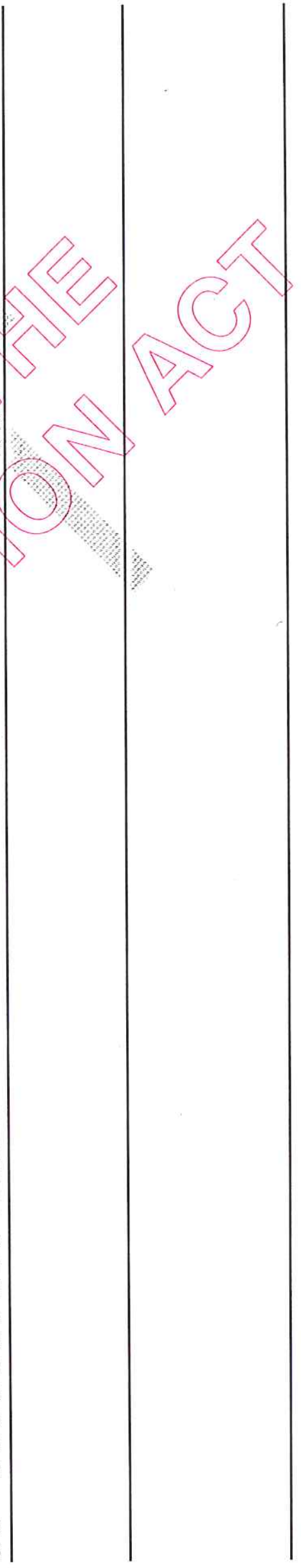


desk in order to select the appropriate setting.

The supply of additional power points to the Court Takers position is a standard requirement.

6.2 Judges Assembly / Retiring room

7.0 Secure Area:

7.1 Lawyers Room with tea-making facility

- A lawyers room will include tea station and access to toilet facilities.

- No changing room necessary as Counsel will likely only be required to wear gowns in court.

- No library facilities will be provided for Counsel. Shelving to be provided in lawyers room.

7.2 Auxiliary room

7.3 Unisex disabled toilet

7.4 Judicial Conference Room

- The Judges conference room may be located near the Court room away from Chambers so as to provide easier access for visitors. The conference room may also be used for leave applications. Video conference facilities wili be required.

\subsection{Catering Kitchen}

8.0 Judicial Areas:

- A separate room is not required for the crown Soliciter as their use will be infrequent

- Provision of garden space for Judges usês desirable. Garden nhould be in sunny aspect and private.

8.1 Judges Chambers \& Ensuite $(7 \times 35 \mathrm{~m} 2)$

- $\quad$ All Judges Ghambers shoüld be co-located however the seventh chamber could be separated if necessary due to planning restrictions.

- Chambers should provide desk and separate work space. Storage should allow for personal reference ibrary (with adjustable open shelving) sind cupboard storage for case files. Computer should be integrated into workstation. Natural light should be provided and acoustic privacy is essentiall. A full en-suite will be provided. Services will include the secure Judicial server, electronic law library and the Internet as well as the other standard operating functions and software packages

\subsection{Gomin on room with kitchenette facility}

\section{Judicial Collegiate Room}

8.3 Judges common room and collegiate work room should be located near chambers.

Enables Judges to gather in the informal setting of the work room, at close proximity to their working space. One of the important benefits to be captured from the setting up of the court is to enhance the opportunities for interaction on a working level which is collegial.

8.4 Chief Justice Chamber \& En-suite

(If the Chief Justice has to travel daily to another location to meet with staff, there is loss of time and disruption of the focus required if the Chief Justice is to lead a collegiate court. There may also be security issues.) 


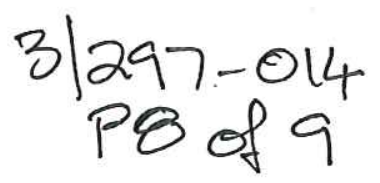

See Memorandum from the Chief Justice, Premises Brief Provisions, 07.11 .03 (paragraph 1.5)

8.5 Chief Justice Support Staff

- $\quad$ Chief Justices support staff should preferably be co-located with Chief Justice.

8.6 Chief Justice meeting room

- Should maintain current capacity of 18 people.

- It is highly desirable to maintain a distinction between areas used for judicial work and those used for administrative purposes for which access by members outside the judiciary is necessary.

8.7 Judicial Communications Advisor

8.8 Judges Associates (8 @ 12m2)

- $\quad$ Associates must be located next to chamber

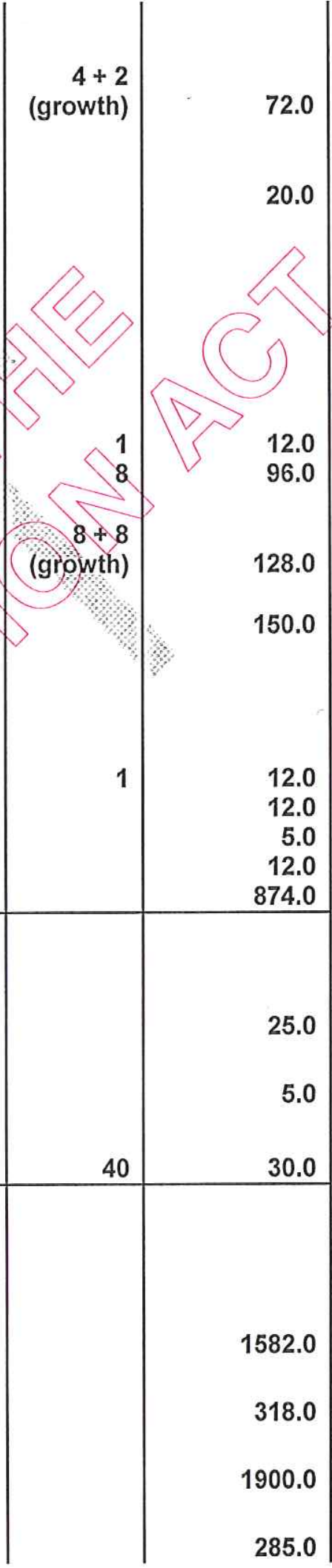

Space Redundancy due to Design Constraints

285.0

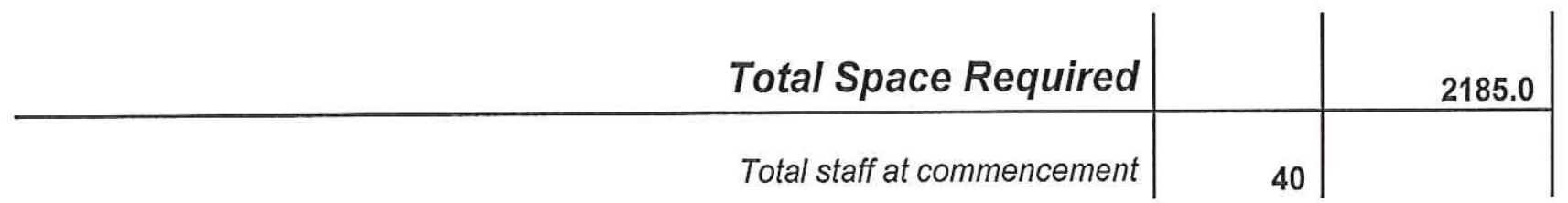




\section{Additional Requirements :}

\subsection{Basement}

10.1 Secure parking for up to 20 motor vehicles.

- Secure car parking to be provided in basement and to link by lift access to Chambers

Sallyport arrangement to be located at the entrance to the basement garage. Two roller doors.

Remotes for roller doors to basement to be programmed on access system.

The entrance to the basement area must be high enough to allow a custodial vehicle to enter.

10.2 Secondary File store (2F/R)

10.3 Secure Rubbish Room

10.4 General Storeroom

10.5 Building Services Rlant, Equipment \& ifits

10.6 Design considerations including circulation, ramps etc $(20 \%)$

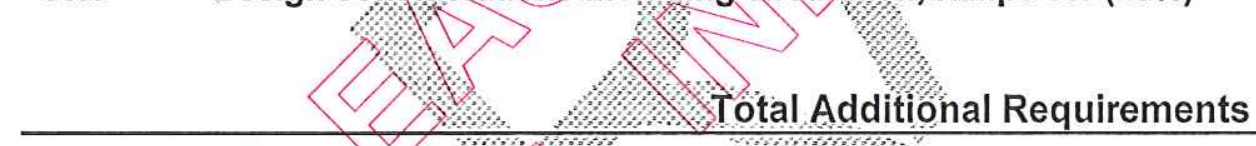

11.0 Items for Clarification

\% The appropriateness of the Whitmore Street or Lambton Quay entry as the main entry.

Identification of preference for either locating Judges clerks with the Associate and Judge (in a suite) or co-locating clerks in a common location near chambers.

Confirmation of preference for a collegiate work practice in chambers.

Confirmation that the building should acknowledge New Zealand's multiculturalism and the addition of Maori cultural elements in Public foyer is appropriate but that these should be excluded from the Court room.

- Number of carpark spaces 


\section{SUPREME COURT}

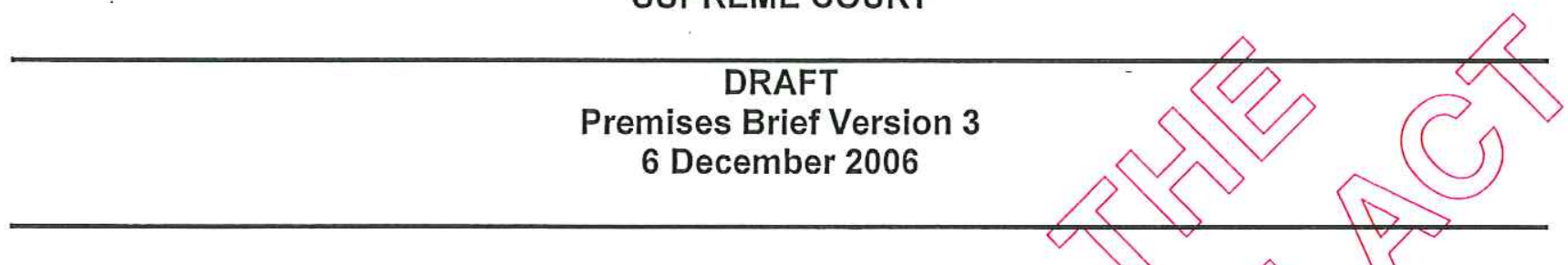

The following notes set out the brief as provided by the Supreme Court Judiciary for the design development for the Supreme Court (New Building and Old High Court Building).

This brief incorporates consultation from the Judiciary and key stakeholders from the period October to November 2006.

A finalized version of this with input from other stakeholders will be submitted for final approval from the Project Steering Group.

This version 3 updates design direction given at Judicial consultation meeting No1 held 3 April 2006, and consultation with users.

\section{DESIGN GUIDE FOR THE SUPREME COURT OF NEWZEALAND}

\section{DRAFT Version 3 December 2006}

1.0

\section{General}

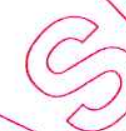
Previous
parameter

The historic building is to be modified by removal the Whitmore Street and part of the Balance Street additions to allow for better efficiency in the connection of the new addition. The building will be fully restored to achieve a $100 \mathrm{yr}$ design life and is to restore the heritage design of No 1 Courtroom.

The building addition exterior should reflect the status of the Supreme Courtas, the repository of NZ law and the apex of the third arm of Government. The building should not be ostentatious but is to be of substance and of enduring design. It is to be respectful to the Historic building but and should not be dominant in relation to the height of the OHCB.

The puiblic entry to the Supreme Court will be from Lambton Quay

The building is to be placed on the site so as to provide an attractive landscape setting with public amenity (seating etc) being incorporated where appropriate.

\subsection{Project Parameters}

- The design and performance of the Supreme Court is to conform with the Key parameters set out in the Ministry of Justice Option C (Modified) Parameters dated 6 April 2006.
New parameter Demolition scope reduced and No1 Court room restored. Scope of functionality and scale of the new addition increased significantly. Entry changed

Park site utilised Key project parameters set by

Cabinet in March 2006 


\subsection{Security Considerations}

- The design and performance of the Supreme Court is to conform with guidelines set out in the Supreme Court Security Design Features Report prepared by Stoks Ltd.

Security requirements amended by Stok report

\section{$2.0 \quad$ Registrar}

$2.1 \quad$ Registrar (office)

\section{Notes from Registry consultation 26 October 2006}

- Core registry functions cannot be split between New Building and $\mathrm{OHCB}$. Transcription and production could go into $\mathrm{OHCB}$.

- Require direct access door into registry aside from reception entry.

- Swap office and meeting room. Office to external window.

- Ballance Street delivery access for after hours mail via a lobby at top of pedestrian ramp would be good.

- Preference for tour groups (school children etc) to go to OHCB entry first to do education video / presentation etc. Visit to Supreme Court to go to court room only. This would reduce interruptions / noise to SC.

- Lawyers attending hearings typically No 4 and up to 10 max

- 2 rooms for lawyers can be smaller that that currently planned.

- Single unisex change room appropriate. Very little demand.

- Cleaners rooms to Ground and first floor to be added Some concern at distance to staff facilities from Registry location but okay.

2.2 Meeting room (to adjoin Registrar's room)

$20 \mathrm{~m} 2$

2.3 Allow for temporarily manned (2 person) sit down counter with a waiting space for up to 10 persons

Law Society Gomment 7 Nov 2006

$30 \mathrm{~m} 2$

$\checkmark$ Request made for parking but accepted none provided as secure judges car park only. Request for drop off parking. This could be provisioned via off street loading car park on Ballance Street entry by arrangement with Registry.

Registrar Total

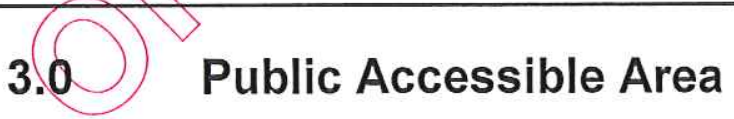

\section{Previous parameter}

New parameter
3.1

Media production room (temporarily occupied with up to 5)

3.2
Security Office (Available to take security threat people for holding or further investigation)

- Located near Commissionaire's station on Whitmore St side of the main foyer from Lambton Quay.

- Is it only occupied during session? Not an office for security staff.

- All other times using security cards 
- A Security guard is to be located in Security Office, on the Ballance St ramped entrance of the OHCB.

$50 \mathrm{~m} 2$

- Consider if the public foyer is suitable as per current size in Old High Court Building

Accommodates

35 people

standing.

- CCTV in Foyer with 21 inch screen in Admin area and security room for security monitoring.

- Consider security expectations for public screening

- Provision also needs to be made for the "in courtroom" images \& sound of proceedings to be transmitted to locations outside of the courtroom i.e. public lobby or to an external location.

Notes from Registry meeting 26 October 2006

- Preference for tour groups (schook children etc) to go to $\mathrm{OHCB}$ entry first to do education video $X$ presentation etc. Visit to Supreme Court to go to courtroom only. This would reduce interruptions / noise to SC

3.4 Public Toilets M \& F

3.5 Disabled Toilet Unisex

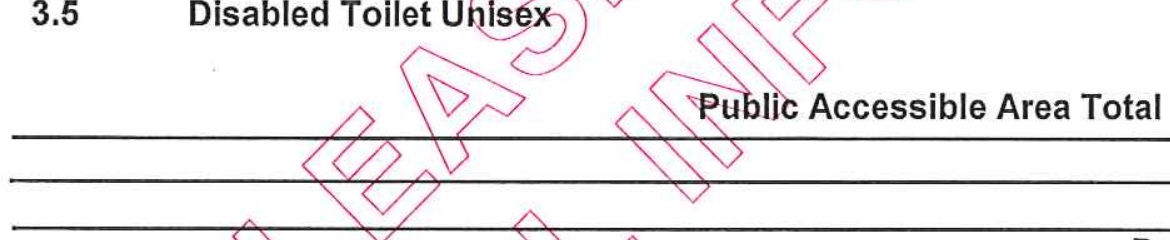

Power point to

be provided for portable meta detector

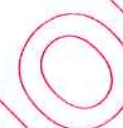

Provision with flat screen as per temp. facility.
$20 \mathrm{~m} 2$

$4 \mathrm{~m} 2$

$106.0 \mathrm{~m} 2$

\subsection{Registry}

4.1

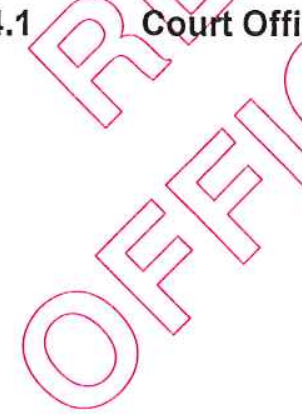


Notes from Registry meeting 26 October 2006

- Core registry functions cannot be split between New Building and OHCB. Transcription and production could go into OHCB.

- Require direct access door into registry aside from reception entry.

- Swap office and meeting room. Office to external window.

- Ballance Street delivery access for after hours mail via a lobby at top of pedestrian ramp would be good.

- Some concern at distance to staff facilities from Registry location but okay.

- Gordon not keen on second secure roller door to basement to provide security separation to judges car park from service vehicle. Prefer control of service vehicle access to basement ie, no access. without notification to registry, use loading park or intercom from ramp.

4.2 Admin Support w/station (1 No.)

- Shut down switch in Admin area located in area of Monitor. Must be lever type switch, in an easily accessible position and clearly labelled.

- 21 inch screen to be provided to monitor public foyer

4.3 Finance Administrator (1/No.)

4.4 Growth w/station (4No.)

4.5 Strong room

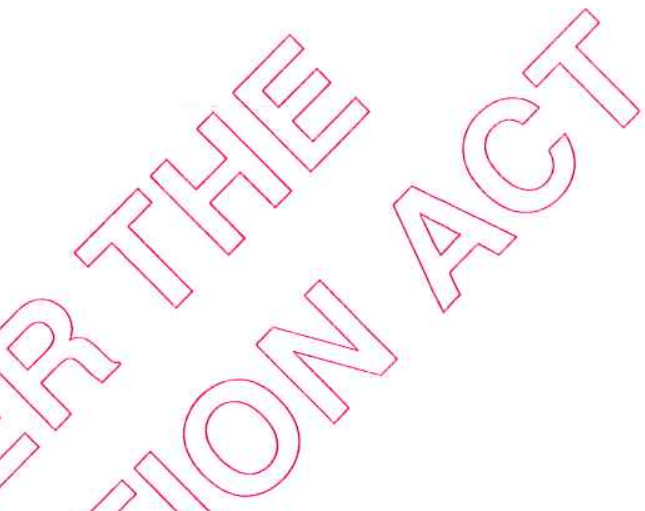

\section{$8.5 \mathrm{~m} 2$}

$12 \mathrm{~m} 2$

$34 \mathrm{~m} 2$

$15 \mathrm{~m} 2$

$20 \mathrm{~m} 2$

File and records management system needs to be flexible for variable case files and provide a convenientand durable handling container. Shelving to be sized to suit file container.

- Case load for Supreme Court estimated as 50-80 cases (approximately 700 heard at Court of Appeal) although cases files will likely be large.

Both electronic and paper files will be required to suit differing work practices

$12 \mathrm{~m} 2$

Provides for Consider paper based possibilities file submissions and multiple copy production. of electronic lodgement and distribution of case files 
4.9 Printers (2)

4.10 Mail area

4.11 Coat cupboard

4.12 Cabinets File (6)

4.13 Bookcase (2)

4.14 Cabinet Store/Stationery type (2)

3.0

4.15

\subsection{Staff Facilities}

Previous parameter
- Staff and Counsel to have separate access to the courtroom from public. Staff to be provided with entry from Ballance Street, with Chief Justice Administration staff access from Whitmore St.

\subsection{Tea-room/Training Room}

5.2 Staff Toilets M\&F

5.3 Uni-sex shower \& disabled toilet

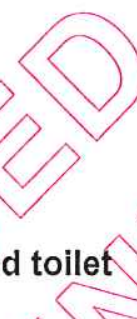

Staff Facilities Total

\subsection{Courtroom Areas:} 6.1 courtroom 1

Consider capacity requirement for public seating. It is acknowledged that on occasions the public interest may exceed seating capacity and this can be mitigated with provision of remote video display of proceedings.

The courtroom needs to be of sufficient width to provide for increased width of bench (from that of Temporary Court) and proportion to suit the increased public seating. A rectangular shape is considered most appropriate.

- Natural daylight is to be provided to the court and preferable to have some outlook from the court.

- Electronic display and video conference facility required in Court Room.

- A sound system must provide a high quality audio level for all speech from Judges and Counsel.
System

functionality as per Temp Court

System functionality as per Temp 
Court

- A system (hearing loops or similar) providing sound for the hearing impaired is also a necessity.

- Full video and audio recording will be required of all proceedings.

- The source to which these recordings are transported will mostly likely take the form of a digital recording system with the ability by the Judiciary to access these recordings with ease.

- The audio recordings are normally captured by means of microphones placed on the bench, counsel desks with cabling leading back to a basic recording and sound rack controlled by the Court Taker.

- These microphones also have a mute button attached to them for personal activation as the situation may require.

- Fixed cameras are to be dispersed throughout the Courtrom in at least 5 positions.

- These cameras record the proceedings of the Courtand are used at the discretion of the Judge. Again either the Judge or the court-taker can control these.

- There may also be a separate camera usually on or near the Court-takers bench for the screening of evidence both written and physical for record purposes and for playing back on screen within the courtroom for all to see.

- The final position of the cameras will be dependent upon direct comment from the Judiciary as to whether on not certain recorded angles are considered necessary.

- We need to look at built-in facilities or the utilisation of the courts own camera recording network to provide footage of "in courtroom" activities to the media. Provision also needs to be made for the "in courtroom" images \& sound of proceedings to be transmitted to locations outside of the courtroom i.e. public lobby or to an external location.
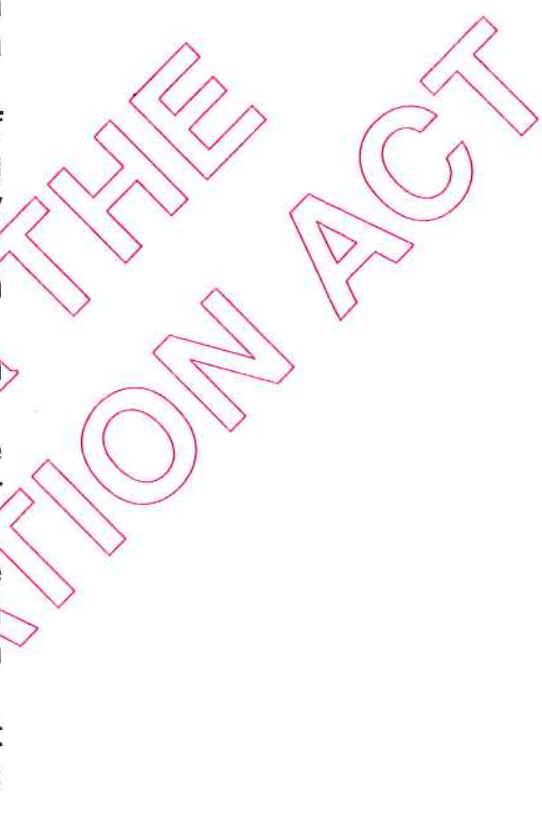

System functionality as per Temp Court

- AYarge LCD screen (or similar) will be needed for the purpose of conveying images to the public gallery. This would service the need for both evidence display as well as video conferencing images.

\section{Law Society Comment 7 Nov 2006}

- Gordon will advise Dick on what cases used video conference so feed back can be given on Temporary Court audio and visual arrangements.

Bench to be set at low level so that eye height when seated matches standing Counsel. Bench to seat five Judges with approximately $1.5 \mathrm{~m}$ work space each. Experience form the Temporary Court indicates width of working space needs to be increased (possibly to 2.0m). Depth of bench should also be increased from that of temporary. Curvature of the bench is to be retained as per the temporary court. Dual computer screens and keyboard to be integrated into bench to allow for both paper based and electronic work practices. Storage for case files to be provided behind bench and on mobile trolleys or integrated into bench. 
- Judges bench must go wall to wall. Duress activators 1 per Judge to be positioned on the privacy panel of the bench. Must be lever type and labelled.

- Whilst seated at the bench the Judiciary will require access to services including those already available in Chambers, such as, the secure Judicial server, electronic law library and the Internet as well as the other standard operating functions and software packages

- A screen, keyboard and PC should be provided for each Judge. All systems available for access by Judges within their Chambers should be provided at the bench. An integrated hardware solution should be developed avoiding the need for laptop use.

- The positioning of the screens and keyboards should not compromise the use of the bench for paper layout etc. The hardware should be able to be largely concealed if the Judges elect not to utilise it and should not be a hindrance to their use of the bench. Screen location must not impede view lines between Judges and Counsel. The upstand hoight of the bench in the temporary court is to be reduced to provide better visibility.

- Screens are to provide video feed and data simultaneously and most likely by way of 2 screens or alternatively yargey split screen.

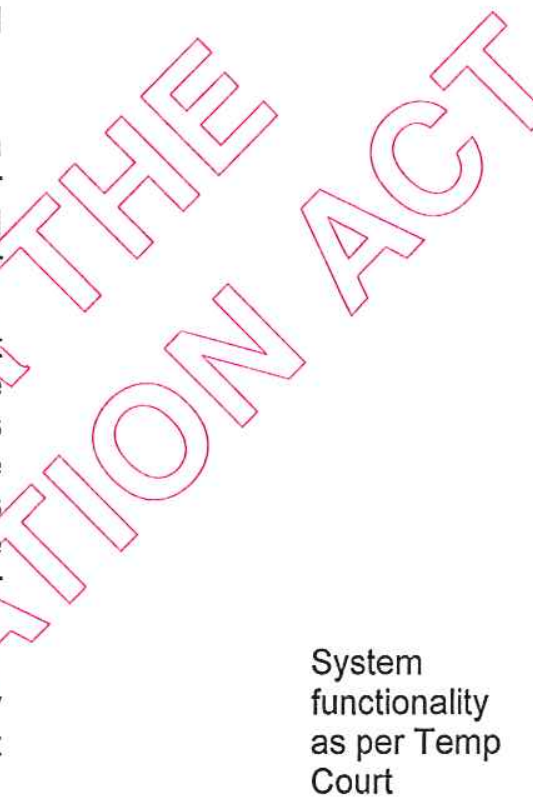


- The control of this display function may remain with the Judges or be left to the operating skills of the Court taker

\subsubsection{Counsel Desks}

- Counsel desks should be flexible to allow for relocation and to cope with variable numbers of Counsel.

20 no.

- A central lectern will be available for the presentation of oral submissions. This lectern will be connected to the sound system for projection of the voice as well as for digital recording.

- Provide gap to counsel benches to provide access to lectern

- Provide microphone to lectern only to avoid risk of inadvertent pick up of counsel conversations in sound system.

- Counsel will be required to be seated at the tables provided starting at a distance of approximately $5.5 \mathrm{~m}$ from the bench. The separation distance should match that at the temporary court.

- Counsel will also need to have external Internet access to their own Law Library and other material such as their electronic database. Flat screen monitors are to be provided to counsel.

- Counsel will also require a clear line of sight to a visual display unit that may $b \hat{b}$ needed to assist during the presentation to the Judiciary. This may take the form of either large LCD (or similar) type screens mounted in full view and in close proximity to the Counsel table. As a preference this screen should also provide display for video conferencing (if required) and be a permanent fixture integrated into the design of the Courtroom.

- Within the tables there will need to be IT \& power outlets for connection purposes that will enable laptops to be used to project their images, via the Court Taker, onto the display units available. 


\section{Law Society Comment No1 Courtroom 7 November 2006}

- A secondary means of egress for counsel is to be provided to avoid main entry re media. This can be by arrangement with the Registry via the Ballance Street access door.

- Distance between counsel benches is to be sufficient to give clear access to lectern past seated counsel

- Consider increase to width of lectern and move slightly forward to give clear separation to opposing counsel. (see notes from Temporary Court Inspection)

- Storage space required at counsel benches for files etc.

- Access to courtroom from side door is requested in lieu of main entry doors.

Law Society Comment after viewing Temporary Supreme Court 10 November 2006

- Increase separation from $1.5 \mathrm{~m}$ to $2.0 \mathrm{~m}$ between counsel benches

- Add rise and fall height adjustment to lectern.

- Create buffer area each side of lectern of about $600 \mathrm{~mm}$ to create separation between counsel and lectern. Do not leave gap between lectern and counsel bench.

- Separation between lectern and bench okay.

- No specific arrangement is provided in the counsel bench design to acknowledge status of Silks over Counsel:

- Provide separation to public seating of $2.0 \mathrm{~m}$ behind rear row of counsel seats.

- A comparative plan between temp court and new Supreme Court would be useful.

\subsubsection{Press Bench}

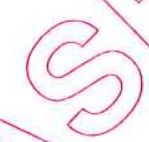

- Dedicated press bench to cater for 6. This should be positioneo with separation to public galley and could be placed to in courtroom to side of counsel benches. One of these spaces to be dedicated for Law Society reporter with slight separation from other press seating.

f

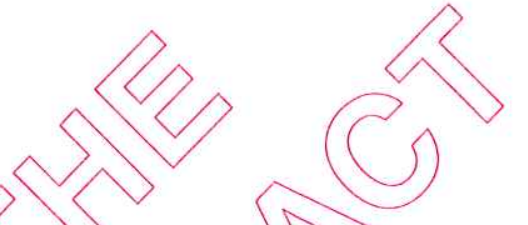

The press must have at the very least the ability to record, via

hand written notes, the proceedings of the day.

\section{1 .4}

\section{Court Taker}

Court Taker will require desk with audio controls etc.

cour

The Court-taker will be responsible for the set up and running of the daily requirements of the Supreme Court.

The ability to control the images, sound, evidence recording and the like displayed on whatever the developed final design solution is, will remain with the Court-taker.

- The lighting to the Courtroom will also be preset to suit the VDU hardware but controls will be provided at the Court takers desk in order to select the appropriate setting.

- The court takers desk position works well in front of and to side of the judge's bench. 


\subsection{Old High Court Building: No1 Courtroom}

\section{The No 1 Courtroom will be used for:}

- Overflow court or hearing centre for other jurisdictions.

- Ceremonial uses EXCLUDING:

- List court.

- Trials court.

- To be designed with flexibility in mind, so to allow an AV system to be used.

\section{Acoustics}

Audio Visual

Good natural acoustics as far as possible, supplemented with an audio and video system.

- Sound system for transcription and sound re-enforcement

- Video recording required, to assist transcribers identify the speaker.

- Videoconference capability, possibly including mobile screens and use of personal PC screens rather than large display screens.

- $\quad$ Preferred equipment is FTR from Transcript, as used in the Temporary Supreme Court.

Lighting Review MoJ Audio Specifications.

- General light levels are to be provided, at approximately 400 to 500 lux at desky level. Task lighting will provide supplementary general lighting at the Judges bench, counsel, and media desks.

- $\quad$ The HPT strongly discourage the uso of pendant lights, such as the lights, which were added in the same period as the lowered ceiling.

- Lighting design to be suitable for video recording, where possible, or else mobile lighting may be suitable.

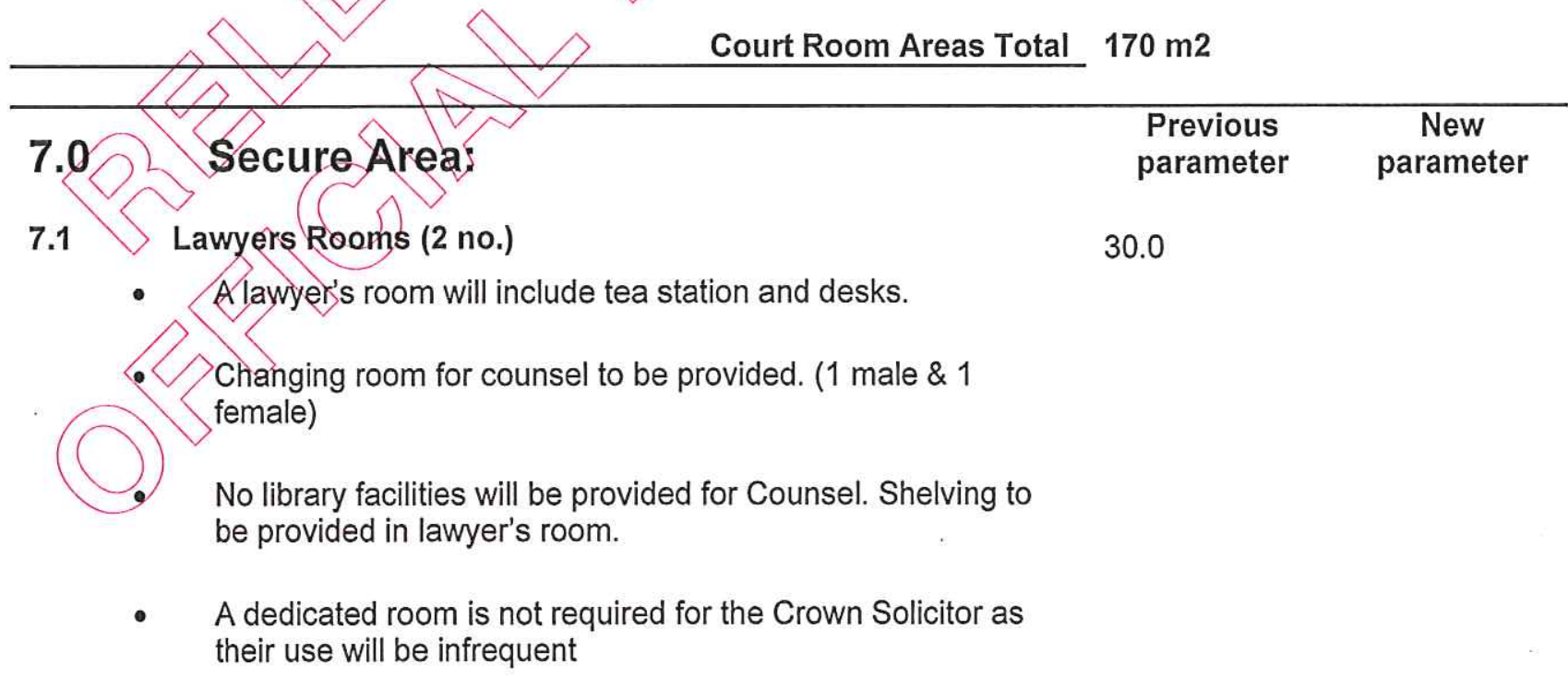




\section{Law Society Comment 7 November 2006}

- Preference for lawyers common room with tea station and storage facilities. In secure area. Separate Male and Female toilets and changing area should be accessible from common room. Common room to accommodate up to 12 Counsel.

- Both opposing counsel will share common room.

- Meeting rooms to be provided. Preference is for 3 of various sizes with a minimum of 2 no.

- Consider use of registry meeting room as flexibility for $3^{\text {rd }}$ counsel meeting room and provide 2 only.

- Meeting rooms sized to accommodate 4-8 people. Consider subdivision with acoustic wall for flexibility.

Note from Registry meeting 26 October 2006

- Lawyers attending hearings typically No 4 and up to 10 max

- 2 rooms for lawyers can be smaller than that currently planned.

- Single unisex change room appropriate. Very little demand.

7.2 Auxiliary room (Interview room) 1 no.

7.3 Unisex disabled toilet (dedicated for counsel use)

- The Judges conference room may be located near the Court room away from Chambers so as to provide easier access for visitors. The conference room may also be used for leave applications. Video conference facilities will be required.

Located in the

No 2 Court

room In OHCB

- Access to the conference roem for Judges must be via private and secuite route.

$$
\text { (n) }
$$

7.5 Catering Kitchen (for Conferenee room) $25 \mathrm{~m} 2$

\subsection{Cleaners Room}

Note from Registry 26 October 2006

Cleaners rooms to Ground and First Floor to be added

\subsection{Judicial Areas:}

Provision of garden space for Judges use is desirable. Garden should be in sunny aspect and private.

\subsection{Judges Chambers \& Ensuite (5 no.)}

- 5 Chambers are to be provided and design should have flexibility for addition of $6^{\text {th }}$ Chamber.

- $\quad$ All Judges Chambers should be co-located .

\section{Previous New parameter parameter} Located in secure courtyard space between buildings.

To be located on first floor for enhanced privacy and security 
- Chambers should provide desk and separate work space. Storage should allow for personal reference library (with adjustable open shelving) and cupboard storage for case files. Computer should be integrated into workstation. Natural light should be provided and acoustic privacy is essential. A full ensuite will be provided. Services will include the secure Judicial server, electronic law library and the Internet as well as the other standard operating functions and software packages

8.2 Chief Justice Chamber \& En-suite (1 no.)

- $\quad$ Co -located with other chambers.

- As per judges chambers but also to include meeting table space.

- Consider provision of small separate meeting room in lieu of larger chamber with meeting table. Meeting room can then be used by other Judges.

- Provide small waiting area (seating) in lobby outside the room.

\subsection{Common room with kitchenette facility.}

$40 \mathrm{~m} 2$

\section{Associates Staff Kitchen Comment 3 November 2006 :}

- Functions are held around the kitchen, with morning and afternoon teas. The kitchen can be used, along with the circulation space, and reading area.

\section{Clerks Staff Kitchen Comment 3 November 2006:}

- Prefer small tables, as opposed to the single large table in the currentroom.

- Possibly a bench to the Ballance Street window with stools.

- Floor coverings to be carpet except in front of the sink area. Appliances: Sink refrigerator, microwave, cool water \& oven.

- Judges common room and collegiate work room should be located near chambers.

Enables Judges to gather in the informal setting of the work room, at close proximity to their working space. One of the important benefits to be captured from the setting up of the court is to enhance the opportunities for interaction on a working level which is collegial.

\section{5}




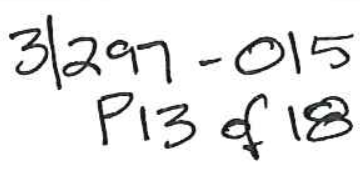

\section{Notes from meeting with Associates 3 November 2006}

- Office space: $13.7 \mathrm{~m} 2$ is the measured space for the Associates offices in the new building, which is larger than the current offices, and a good size.

- Partition to the Clerks space to be opaque for lower section, so that they cannot see the Associates. Upper section to be clear, and full height.

- $\quad$ Sound from the Associates rooms to the Clerks rooms is to be minimized.

- Sound absorbency is important, so that the Clerks and Associates can work independently.

- Desks: Associates prefer the desks to be loose, so that they can be orientated to avoid screen glare, and provide flexibility,

- $\quad$ Blinds are to be provided.

- $\quad$ Shelving on outside wall to be below $700 \mathrm{~mm} \& 2.5 \mathrm{~m} /$ tong. Depth needs to be sufficient to hold an Eastlite folder.

" Shelving needs to be maximized, without a set length being advised.

- Note WAM \& The Building Intelligence Group visited temporary Supreme Court location and measured existing shelf space at 10 to 16 lineal metres, and $50 \%$ used.

- Printer in each office to be an HP printer, and a fax is preferred.

8.6 Judges Clerks (16 @ 8m2)

- Clerk to be located close to Associates

- Includes provision of 8 growth positions

Notes from meeting with Clerks 3 Nov 2006

- Prevent sounid from the Associates rooms travelling to the Clerks rooms.

- Meeting foom on Lambton Quay: Justice Tipping advises it is ideal for Clerks meetings.

- Desks: Require a lot of desk space with returns, and prefer free standing desks, so that they can be moved to suitpersonal taste.

Storage: Lots of shelving required, as Clerks hold duplicates of Judges files.

o High shelving is good.

- Note: Clerks existing shelf space is to be measured, as a basis for the designed length. The length of shelving is measured as 3 lineal metres of shelf space each, plus overflow desk space, however this insufficient for their needs.

Storage area for common files required, which could be the utility room, and storage room in the basement for archive files.

- Utility room requires photocopier, shredder, and lots of bench space for collating material.

- Periodical space to include seats and table, to provide a comfortable space to read. The intention is to provide this space on the $1^{\text {st }}$ floor between the lift and stairwell. 
- Ventilation: The building will have opening windows, along with individualized control, so that if Judges prefer a colder room, the clerks can have warmer rooms.

- Possibly under floor heating, however the time lag could be uncomfortable during the time that the concrete changes temperature.

- Clerks advise that there is no need for full air conditioning.

- This comment is inconsistent with the previous note.

- Lights: Current fluorescents are too bright, causing eye problems for clerks. The preference is for general lighting, and task lighting over the desks, however there is a need for sufficient lighting at night.

- Security: Unauthorised people now enter the building, and the Clerks want better control in the new building. The new building is going through a security review, and likely to have two lines of control before authorized staff can enter the $1^{\text {st }}$ floor.

Floor coverings: Carpet is likely to be used for offices, to gain as much sound absorbency as possible.

8.7

Chief Justice Support Staff (6 @ 12m2)

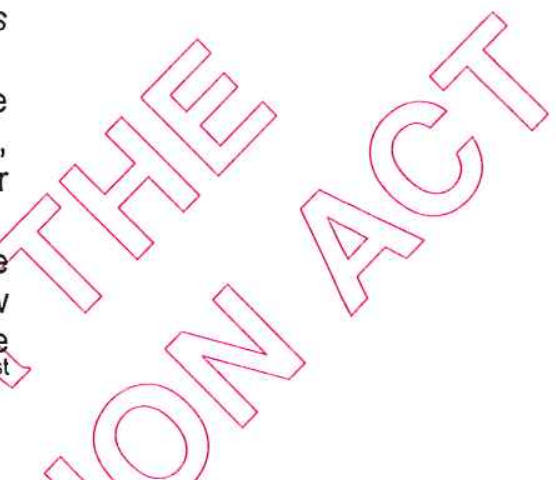

Chief Justices support staff Should be separated from Judicial chamber suite but close by to provide efficient access for the Chief Justice.

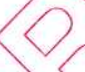

- Includes 2 growth positions.

Comment from Chief Justices Administrator 1 November 2006

- Judges retiring roorn should contain a set of Statues and NZ Law reports.

- Confidentiality requires separation for admin area from registry staff.

- File storage facility required. This should be localised near support office. Use adjoining room with connecting door.

- Gurrent files have been created since 1999 so allowance required for future growth.

Need security access control to file store and possibly to offices. To maintain confidentiality of other users, access $\mathrm{OHCB}$ from Whitmore Street entry.

CJ Associate need's work space in admin area. Look at provisioning this by subdividing toilet space next to CJ's office.

- Kerin-Policy / Legal - Need's office

Polly - Finance / Admin - PC Workstation

Karen - PA Admin Support - PC Workstation

Future - Website Administrator - PC Workstation

Future - Communications Person - PC Workstation

Staff need $1800 \times 1800$ workstation.

No need for much localised storage at workstation. Use centralised storage into file store room.

- Kieran notes preference for offices for CJ staff inlieu of open plan. Consider partition screens and acoustic treatments.

- Kerin needs some layout space and file storage in office.

- $\quad$ Provide workstation and meeting chair for visitor for Kerin's office.

- Kerin needs access to law Statues. Best in Kerin's office.

- Kerin also needs desktop printer.

- Utility space needed for photocopier / printer in file store area. 


\section{$3 \mid 297-015$ \\ P 15 of 18}

- This also requires production and collating space for documentation preparation.

- Small library storage requirement could be in open plan office room.

- Consider provision for waiting area for guests to see $\mathrm{CJ}$ at admin office or meeting room.

- $\quad$ Possibly put seating in lobby between OHCB and Supreme Court or provide soft seating in meeting room.

- It is highly desirable to maintain a distinction between areas used for judicial work and those used for administrative purposes for which access by members outside the judiciary is necessary.

- Capacity for up to 18 people.

8.9 Judicial Communications Advisor (I no in office)

8.10 Other possible occupants of the OHCB open plan space

\section{Notes from CJ Administration Managers meeting 1 Nov 2006}

- CJ suggests Institute of Judicial Studies (IJS) as option for occupation of space in $\mathrm{OHCB}$. (Manager and 3-4 Staff). They could be accommodated on $1^{\text {st }}$ floor of OHCB.

- IJS may have seminars of up to 40 people. The old Registry may be suitable as seminar room.

- IJS may be better in old registry space for seminar usage and to reduce security issues.

- Consider removal of some of the subdivision shown on level 1 of $\mathrm{OHCB}$, ie, provide more open plan layout and preserve heritage walls of importance only.

8.11 Library (Includes for Judges reading area \& Clerks research area)

The library is to provide a Judges reading area for periodicals. This should be comfortable quiet space.

A Clerks/Researchers working area is required in the library.

2500 lineal meter of shelving in one dedicated facility

$2400 \mathrm{Im}$ including use of circulation space on $1^{\text {st }}$ floor

Library could be split over two levels.

\section{Clerks Library comment}

- Require one work station with PC for searching, and to be able to send documents to own workstation.

- $\quad$ Clerks Library comment: Shelving to be located in the public spaces of the $1^{\text {st }}$ floor. 


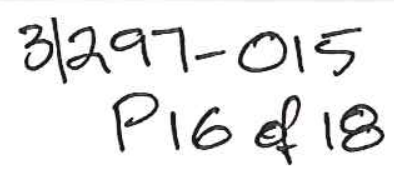

8.12 Librarian (I no. in office).

Librarian assistant also to be accommodated within Librarians office.

Notes from meeting with Sara Cleghorn, Supreme Court Librarian 26 October 2006.

- 2400 lineal meters of shelving provisioned in current plan. Sara confirms this is satisfactory in lieu of 2500 lin meter target.

- $\quad$ Roy proposes provision of additional storage by use of built in book case shelving to corridors outside chambers. Agreed this would be desirable.

- $\quad$ Public Access would be limited to practitioners accessing the library by arrangement only. Provide secure lobby / counter accessed from Public area via security door. Practitioners would access by arrangement from Registry. No 'browsing' access would be available.

- Internal stair location flexible.

- $\quad$ Preference is for office / work room on first floor of library.

- $\quad$ Require flexible work room that provides workspace for 2 staff. Straight bench configuration preferable.

- 2 PC's 1 on each floor for library catalogue search.

- 2 PC's no other specialist equipment - Clerks note requests $1 \mathrm{PC}$ only.

- Photocopier needed but acess to utility on 11 would provide these.

- $\quad$ Reading area to provide periodical display and new book display. Newspaper bench and storage for 1 month. Preference for Crown Law library layout low level to centre and high level to perimeters.

- Crown lawnewspaper bench to be used as design guide. Ian to provide plan.

- Shelving to be arranged in 'Room' arrangement on top floor and half of ground floor. Balance of ground floor can be ailse type shelving (stack storage) within library.

- Minimum of $1 \mathrm{~m}$ separation between stack storage shelves on ground floor.

Future proof floor loading on ground floor to provision for future compactor shelving.

Preference for wooden adjustable shelving.

Reading ledges in bookshelves not necessary.

- Bookshelves to give privacy to perimeter windows.

No workstations required for research. Provide individual table and chairs in library for quick reading.

Large storage cupboard for spare books / boxes / bubble wrap etc .

Doors to give good width for trolly access.

No historical book collections requiring specialist environmental control for preservation.

- $\quad$ South side location for library good. Good UV protection.

- General lighting sufficient to provide light to read spine of books in shelves.

- Supplementary task lighting over reading tables.

- Would prefer to have all storage at initial occupancy. Okay that some shelving will be empty. 
Notes from meeting with Clerks 3 Nov 2006

- Toilets: Qty 4 toilets for 10 people is considered sufficient, with separate male and female showers in OHCB.

- $\quad$ M/F mix is biased towards female, so prefer some flexibility to use more toilets for women.

\subsection{Disabled Toilet/Shower}

\section{Notes from meeting with Clerks 3 Nov 2006}

- Utility room requires photocopier, shredder, and lots of bench space for collating material.

8.15 Utility Room (photo copier/fax/printer/stores)

\section{$9.0 \quad$ Basement}

9.1 Secure parking for motor vehicles.

- Secure car parking to be provided in basement and to link by lift access to Chambers

- Remotes for roller doors to basement to be programmed on access system.

- $\quad$ No custodial facilities or sally port provided. Any custodial handling to be provided by District Court facilities.

Notes from Registry consultation 26 October 2006

- Gordon not Reen on second secure roller door to basement to provide security separation to judges car park from service vehjicle. Rrefer control of service vehicle access to basement je no access without notification to registry, use loading park or intercom from ramp.

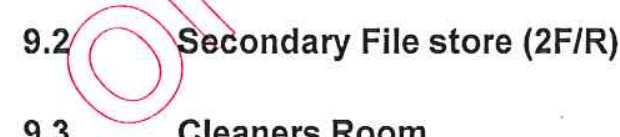

$30.0 \mathrm{~m} 2$

9.3

Cleaners Room

Notes from Registry consultation 26 October 2006

- Cleaners rooms to Ground and First Floor to be added

9.4 Secure Rubbish Room

$8.0 \mathrm{~m} 2$

9.5 General Storeroom

$20.0 \mathrm{~m} 2$ 


\section{$31297-015$ \\ P18 of 18}

9.6 Building Services Plant, Equipment \& Lifts

\section{Total Occupants}

Refer Occupant Load note of 24 October 2006.

- Peak allowance New Building 161.

o Staff: Normal use 27

- Peak load for OHCB of 139.

- Staff: Normal use 33

- Total of 300 people.

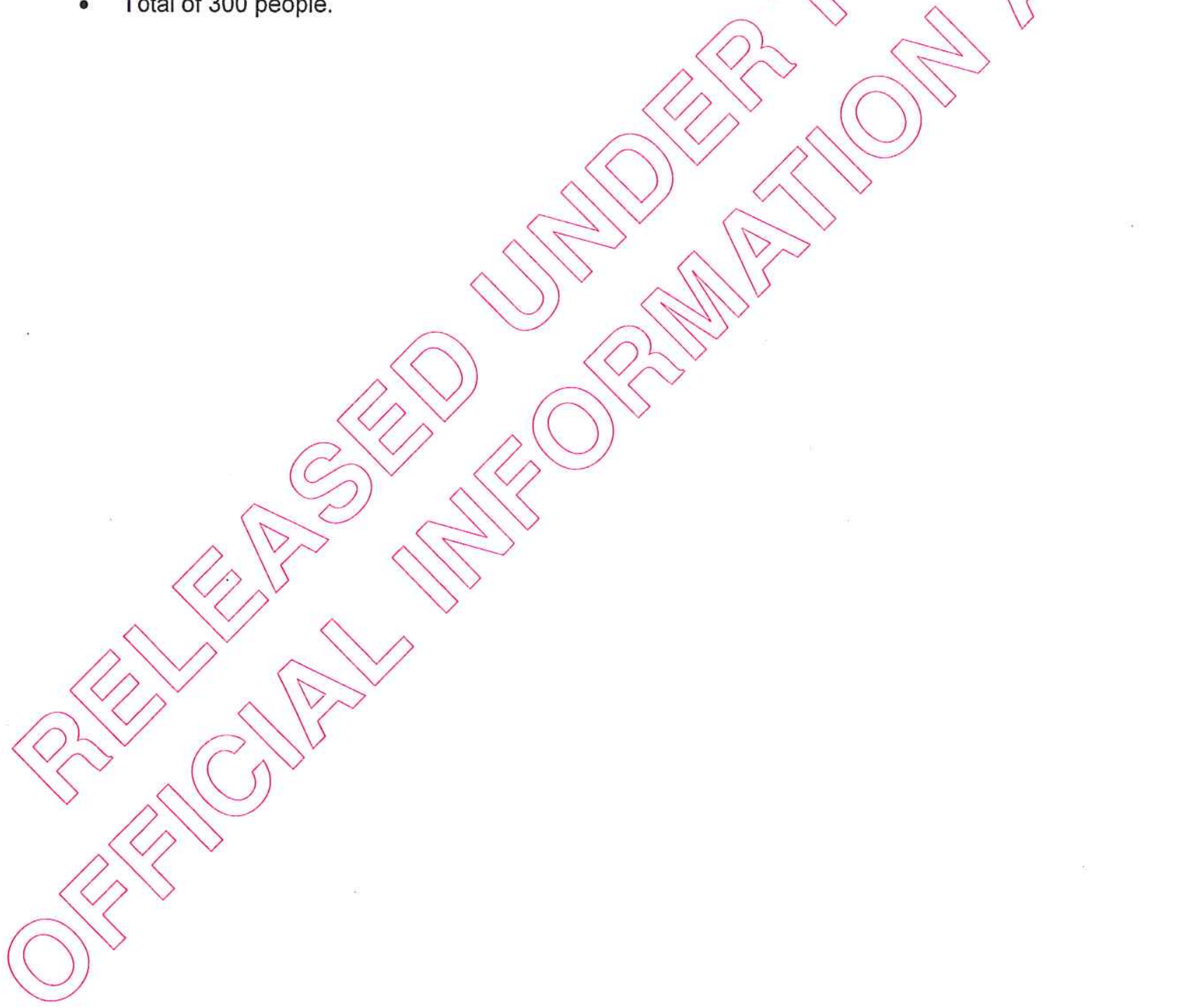




\section{$31297-016$}

P1 of 17

\section{SUPREME COURT}

\section{Premises Brief Version 4} 28 March 2007

The following notes set out the brief for the design development for the Supreme Count (New Building and Old High Court Building).

This brief incorporates consultation with the Judiciary and key stakeholders from the period October 2006 to February 2007.

A finalised version, with sign off from stakeholders, will be submitted for final approval from the Project Steering Group.

\begin{tabular}{|c|c|}
\hline DESIGN GUIDE FOR THE SUPREME COURT OF NEW ZEALAND $\gg$ & \\
\hline DRAFT March 2007 & \\
\hline 1.0 General & \\
\hline $\begin{array}{l}\text { The historic building is to be modified by removal of the } 1913 \text { Whitmore Street and } \\
\text { part of the } 1907 \text { Ballance Street additions, to allow for better efficiency in the new } \\
\text { building. The OHCB will befully restored to achieve a } 100 \mathrm{yr} \text { design life, with } \\
\text { functional improvements, in luding the No1 and No2 Courtrooms. }\end{array}$ & \\
\hline $\begin{array}{l}\text { The NewBuilding exterior should reflect the status of the Supreme Court as the } \\
\text { repository of NZ law and the apex of the third arm of Government. The building } \\
\text { should not be ostentatious but is to be of substance and of enduring design. It is to be } \\
\text { respectful to the Historig building and should not be dominant in relation to the height } \\
\text { of the OHCB. }\end{array}$ & \\
\hline The public entry to the Supreme Court will be from Lambton Quay. & \\
\hline $\begin{array}{l}\text { The new building will be located on the original site of the Armed Constabulary and } \\
\text { Coyrt of Arbitration buildings, now known as Justice Park. } \\
\text { Public seating is to be located on the Whitmore St and Ballance St frontages, } \\
\text { howeyer security objectives are to be incorporated, limiting access to the building } \\
\text { facades. }\end{array}$ & \\
\hline
\end{tabular}




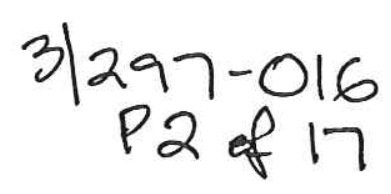

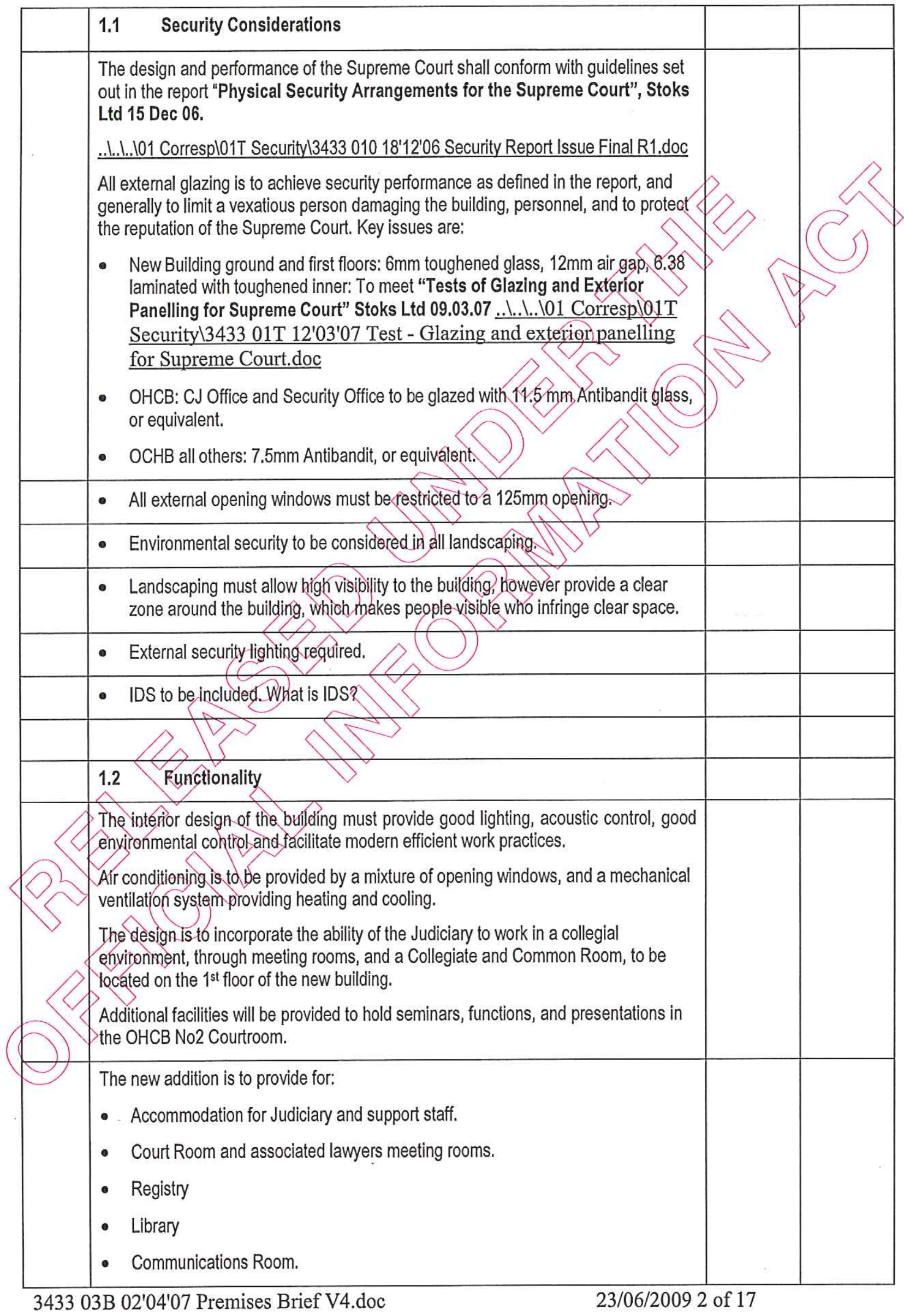




\begin{tabular}{|c|c|c|c|}
\hline & $\begin{array}{l}\text { - Media Room. } \\
\text { - Holding Room. }\end{array}$ & & \\
\hline & $\begin{array}{l}\text { The Historic Building is to provide functional usage for the Supreme Court, including: } \\
\text { - Chief Justice Administration. } \\
\text { - CJ meeting room. } \\
\text { - Retiring room. } \\
\text { - Security office, and trade deliveries. } \\
\text { - Reheat kitchen to service the No2 Courtroom. } \\
\text { - Registry overflow, transcription and production. } \\
\text { - Communications room. } \\
\text { - Counsel rooms to service the No1 Courtroom. } \\
\text { - Additional space will be provided as functional office space, including the Old } \\
\text { The No1 Courtry on the Whitmore/Stout St corner, and the will be designeor flo offices. } \\
\text { Court, hearings, ceremonial and moot court..1t will not service criminal courts, as there } \\
\text { are no compliant holding facilities. }\end{array}$ & & \\
\hline Room & New Building & Area $\mathrm{m} 2$ & People \\
\hline & $\begin{array}{l}\text { Entry off Ballance Street, through a card activated gate, roller doors, with the first } \\
\text { roller door, at a minimum, being high speed. } \\
\text { Entry into the lift and stairs would be card controlled, from the secure carpark area for } \\
\text { the judges, and from the area between the roller doors for trades, and controlled by } \\
\text { Registry. } \\
\text { Entry to the plant and sprinkler rooms would be between the secure roller doors. } \\
\text { Basement ceiling height tbc }\end{array}$ & & \\
\hline & Basement to incorporate: & & \\
\hline B001 & - Trade vehicle park qty 1 & & \\
\hline & $\begin{array}{l}\text { - Secure rubbish storage - Security provisioned as it is located between the } \\
\text { roller doors. }\end{array}$ & 8 & \\
\hline B002 & - Entry bay & 164 & \\
\hline B003 & - Lift lobby: Confirm entry by trades. & & \\
\hline B004 & - Plant room & 197 & \\
\hline B005 & - Transformer & 21 & \\
\hline
\end{tabular}




\begin{tabular}{|c|c|c|c|}
\hline Room & 2.1 Basement & Area $\mathrm{m} 2$ & People \\
\hline B006 & - Main Circuit Board: MSB & 14.5 & \\
\hline B007 & - Store room & 49 & \\
\hline B008 & - North plant passage & & \\
\hline B009 & - West sub floor & & \\
\hline B010 & - South sub floor & & \\
\hline B011 & - Parking for 12 cars, plus 5 bikes on a wall mounted rack & & \\
\hline B012 & - Stair lobby: No entry from ramp. & & \\
\hline B012 & - Cleaners storage under circular stairs TBA & & \\
\hline B013 & - Sprinkler room: Entry through separate door. & 39 & \\
\hline \multirow[t]{4}{*}{ B014 } & - Vehicle access ramp & & \\
\hline & $\begin{array}{l}\text { Basement access is through the card operated secuity system, and trades access is } \\
\text { through prior arrangement with Registry, and/or Intercom from ramp or Poading bay off } \\
\text { Ballance St. }\end{array}$ & & \\
\hline & No custodial facilities will be provided. & & \\
\hline & Access to the OHCB sub floor from BO01. & & \\
\hline
\end{tabular}

\begin{tabular}{|c|c|c|c|}
\hline Room & 2.2 Ground fl & Area $\mathrm{m} 2$ & People \\
\hline & $\begin{array}{l}\text { Security: } \\
\text { The design and performance of the Supreme Court shall conform with guidelines set } \\
\text { out in the report "Physical Security Arrangements for the Supreme Court", Stoks Ltd } \\
15 \text { Dec } 06 \text {. }\end{array}$ & & \\
\hline & $\begin{array}{l}\text { Entry air lock to incorporate entry past security screening system on north side, exit } \\
\text { via south side, and ceremonial entry/exit via central position. }\end{array}$ & & \\
\hline G003 & $\begin{array}{l}\text { Main public foyer (Vestibule) Allows for up to } 30 \text { overflow public to view proceedings } \\
\text { on a remote screen located in the south side. } \\
\text { Natural light will spill from the roof mounted skylights, located around the } \\
\text { orb, and } 1 \text { st floor glass floor around the orb. } \\
\text { Security Concierge to be located to north side, where first contact and entry } \\
\text { to registry is sought. } \\
\text { - Tour groups to be met in foyer, with screen presentation in foyer, or in } \\
\text { courtroom if not occupied. }\end{array}$ & Tba & $\begin{array}{r}30 \\
\text { overflow } \\
\text { from Court }\end{array}$ \\
\hline
\end{tabular}




\section{$3 / 297-016$ \\ P5 of 17}

\begin{tabular}{|c|c|c|c|}
\hline Room & 2.2 Ground floor & Area $\mathrm{m} 2$ & People \\
\hline \multirow[t]{3}{*}{ G004 } & 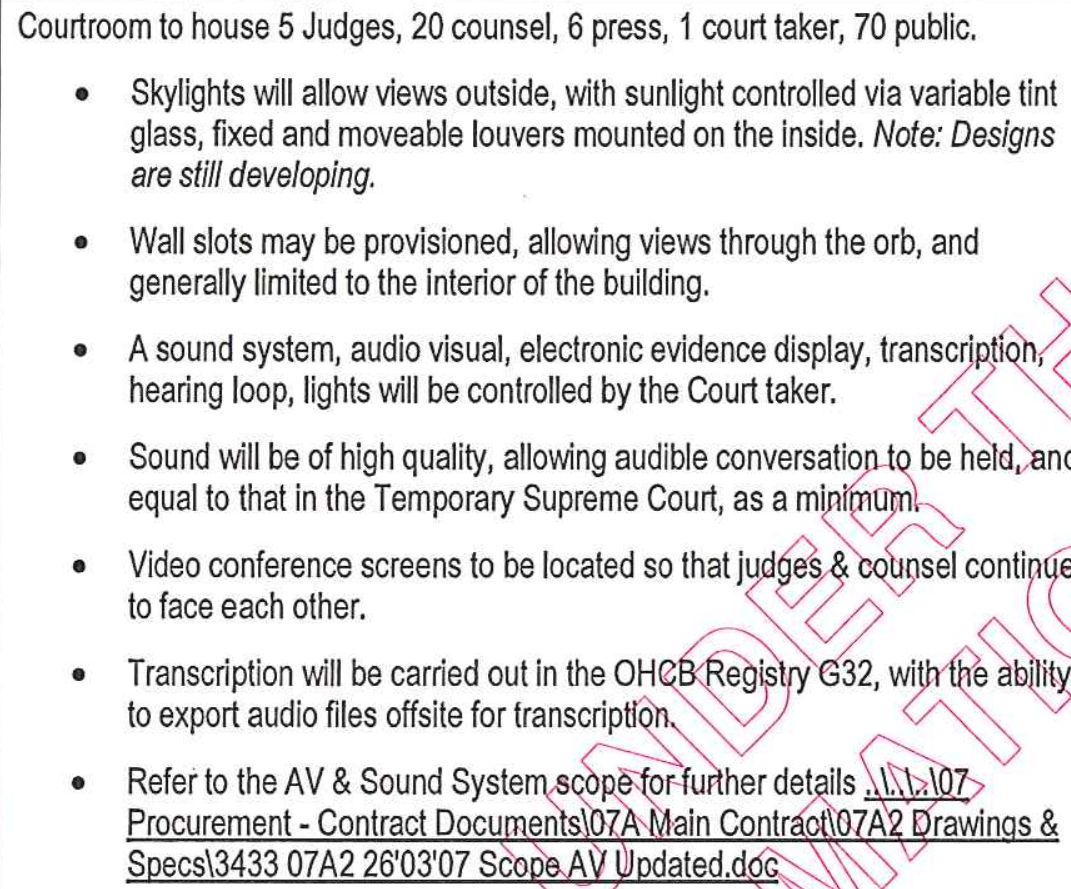 & 223 & 102 \\
\hline & ) & & \\
\hline & 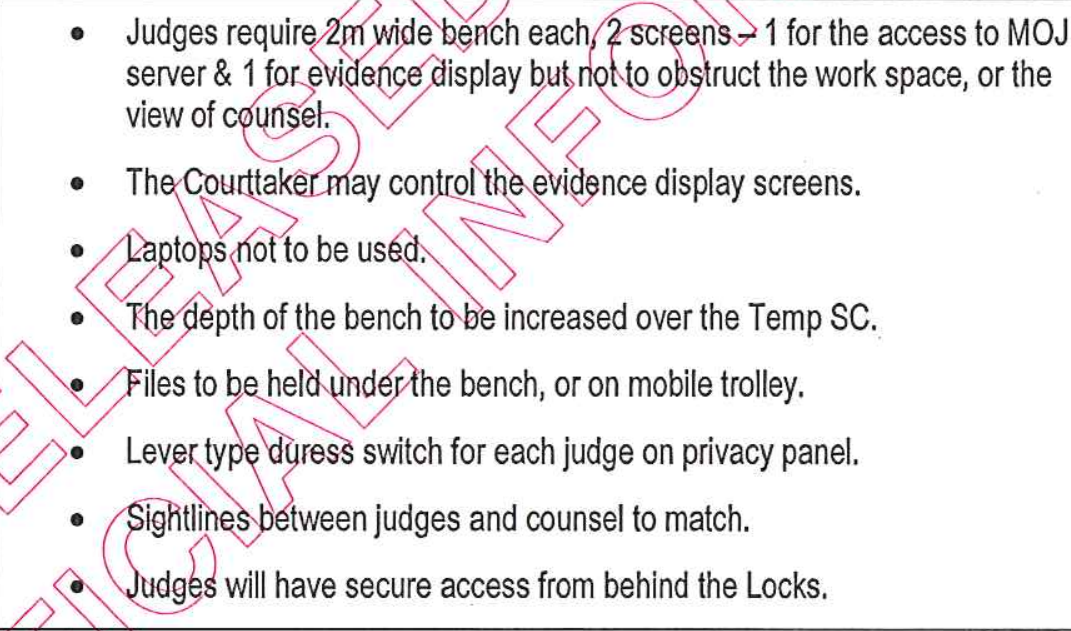 & & \\
\hline
\end{tabular}




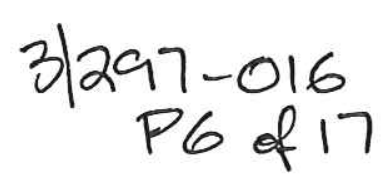

\begin{tabular}{|c|c|c|c|}
\hline Room & 2.2 Ground floor & Area m2 & People \\
\hline & Counsel & & $\begin{array}{r}\text { See } \\
\text { Courtroom }\end{array}$ \\
\hline & $\begin{array}{l}\text { - A central rise and fall lectern will be provided for counsel to present, with } \\
\text { counsel benches either side, and clear access past seated colleagues. The } \\
\text { lectern will be slightly forward of the counsel benches. } \\
\text { - The distance to the bench will be equivalent to the Temporary Supreme } \\
\text { Court. } \\
\text { - Counsel benches to be separated from opposing teams and public by } 2 \mathrm{~m} \text {. } \\
\text { and to incorporate file storage. } \\
\text { - Power points and internet access will be provided, for counsel supplied } \\
\text { laptops, but completely separate from the MOJ seryers. } \\
\text { - Fixed evidence display screens will be provided. Reer AV/sS brief as } \\
\text { above. } \\
\text { - Counsel entry and exit to be via side doors through Lock G01 \& potentially } \\
\text { - Lock G025, into Passage G013 and allocated rooms. } \\
\text { - Half height entry doors from Puiblic space to Counsel to be locked. }\end{array}$ & & \\
\hline & Press Benches & & \\
\hline & $\begin{array}{l}\text { Bench to cater for } 6 \text { reporters, } 3 \text { elther side of public seating, with power points and } \\
\text { internet access, separate from MIOJ servers. } \\
\text { These are to be separated trom public by } 2 \mathrm{~m} \text {. }\end{array}$ & & \\
\hline & Court taker $>$ & & \\
\hline & $\begin{array}{l}\text { Desk will require } 2 X 17 \text { (or 19) inch screens, along with a } 12^{\prime \prime} \text { to } 15^{\prime \prime} \text { touch screen, for } \\
\text { full control of the AV/Sound/Evidence display. Desk location to be in front of \& to the } \\
\text { side of the judge's bench. }\end{array}$ & & \\
\hline $6005 /$ & Public toilets to be located in foyer, and entry visible by Security Concierge. & & 5 \\
\hline G007 & $\begin{array}{l}\text { Interview tholding room to be located behind the Security Concierge, and to be } \\
\text { constructed in a manner that people needing to be removed can be interviewed in a } \\
\text { secure manner. }\end{array}$ & 6 & 2 \\
\hline 6009 & Broadcast room & 11 & 5 \\
\hline G008) & Registrars office & 15 & 1 \\
\hline
\end{tabular}




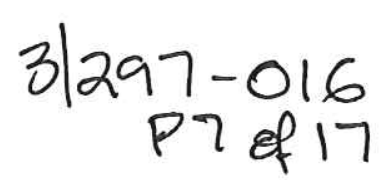

\begin{tabular}{|c|c|c|c|}
\hline Room & 2.2 Ground floor & Area m2 & People \\
\hline G010 & $\begin{array}{l}\text { Registry: Main functions to be house in the new building, with production and } \\
\text { transcription to be housed in the OHCB. A window to accept questions and lodging } \\
\text { documents is to be accessible from the foyer. } \\
\text { Access through secure area } \\
\text { Deliveries to be made from the Ballance St ramp by Security office. } \\
21 \text { inch screen for CCTV display with location tba. } \\
\text { Shutdown lever type switch: Function tba. } \\
\text { Kitchen facilities located in OHCB staff room. } \\
\text { Registry control trades access to the basement and building. } \\
\text { Strong room } \\
\text { Shelving type to be specified in conjunction with Registry. } \\
\text { Equipment to include Fax, printers qty2. } \\
\text { Furniture to include Coat cupboard, mail area, bookcases, filing cabinets, stationary } \\
\text { store/cupboard, recycling bins. }\end{array}$ & 44 & 5 \\
\hline G011 & Security lock access to limit access to the Courtroom. & & \\
\hline G012 & $\begin{array}{l}\text { Comms room, with service riser backing onto Registrn, The room will house } 2 \text { racks, } \\
\text { UPS, a small desk, and releyant patch panels. }\end{array}$ & 8.1 & \\
\hline G013 & Passage & & \\
\hline G014 & $\begin{array}{l}\text { Lawyers room: Occupied during periods of the day during a case, and vacant while } \\
\text { lawyers are in the Courtroom. }\end{array}$ & 7 & 4 \\
\hline G015 & $\begin{array}{l}\text { Meeting room principally for counsel, and Registry when not otherwise used. } \\
\text { Consider acoustic walk to G014 or G016. } \\
\text { Registry may prefer the meeting room is located beside Registry, rather than one } \\
\text { room over. }\end{array}$ & 15 & 8 \\
\hline 5016 & $\begin{array}{l}\text { Lawyers room: Occupied during periods of the day during a case, and vacant while } \\
\text { lawyers are inthe Courtroom. }\end{array}$ & 7 & 4 \\
\hline G017 & $\begin{array}{l}\text { Shared common room for counsel. Registry will use the room when not otherwise in } \\
\text { use by lawyers. To include a kitchenette, with microwave, jug, underbench fridge. }\end{array}$ & 38 & 16 \\
\hline G018 & Toilet: Accessible for counsel. & & \\
\hline G019) & Cleaners room & & \\
\hline G020 & Lawyers change and toilet & & \\
\hline G021 & Lawyers change and toilet & & \\
\hline G022 & Secure lobby and connection to the OHCB. Houses stair and lift to 1 st floor and roof. & & \\
\hline G023 & $\begin{array}{l}\text { Research work room to allow outside legal staff to access the Supreme Court library. } \\
\text { Room to be secure, and access by arrangement. }\end{array}$ & 29 & 3 \\
\hline
\end{tabular}




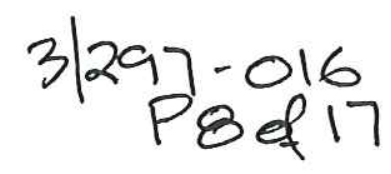

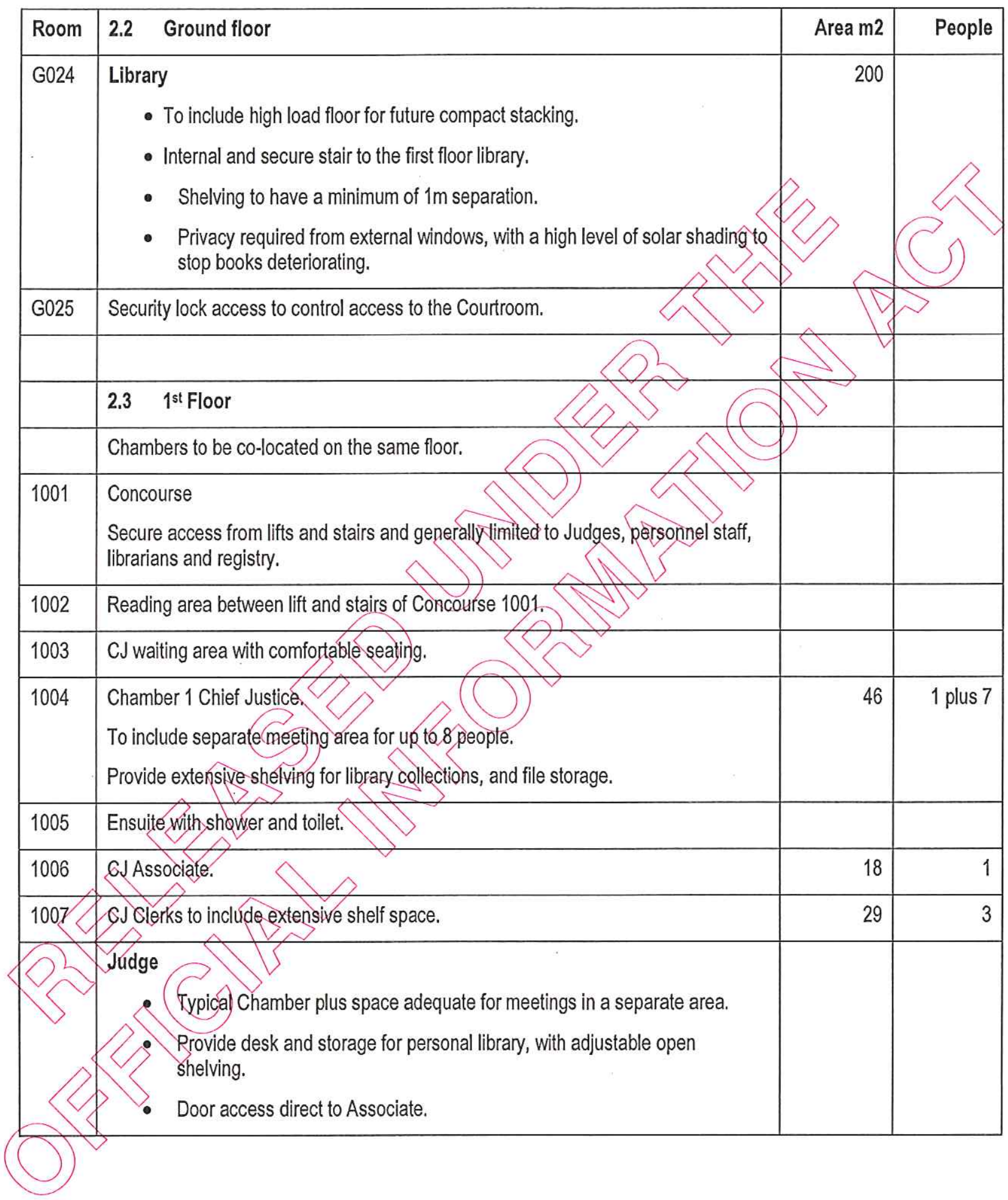




\begin{tabular}{|c|c|c|c|}
\hline Room & 2.3 1st Floor & Area $\mathrm{m} 2$ & People \\
\hline & $\begin{array}{l}\text { Associate } \\
\text { - Typical Chamber with access door to Judge. } \\
\text { - Located by windows for natural light. } \\
\text { - Access to Concourse through Clerks space. } \\
\text { - High level of acoustic and visual separation to Clerks required. } \\
\text { - Desks to be loose item, rather than fitted. } \\
\text { - Large shelf space to be provided, and to allow Eastlite folders. } \\
\text { - Printers required, and fax preferred. }\end{array}$ & & \\
\hline & $\begin{array}{l}\text { Clerks } \\
\text { - Typical Chamber located off concourse, with access to judge throught } \\
\text { Associates room. } \\
\text { - Large desk areas required, and to be loose items, to allow for position } \\
\text { changes. } \\
\text { - Shelving to include high level shelves and large lengths, to allow for } \\
\text { duplicates of judges files. } \\
\text { - Lighting to be to a reasonable level, with tás klighting over desks. } \\
\text { - Opening windows preferred and good control of temperature for each room. }\end{array}$ & & \\
\hline 1008 & Chamber 2 Judge $C$ & 37 & 1 plus 2 \\
\hline 1009 & Chamber 2 ensuite with shower and toilet. & & \\
\hline 1010 & Chamber 2Associate & 12 & 1 \\
\hline 1011 & Chamber 2clerks & 17 & 2 \\
\hline 1012 & Chamber 3 Assosiate & 12 & 1 \\
\hline 1013 & Chamber 3 glerks & 17 & 2 \\
\hline 1014 & Chamber 3 Judge & 37 & 1 plus 2 \\
\hline 1015 & Chamber 3 ensuite with shower and toilet & & \\
\hline 1016 & Chamber 4 ensuite with shower and toilet & & \\
\hline 1017) & Chamber 4 Judge & 37 & 1 plus 2 \\
\hline 1018 & Chamber 4 Associate & 12 & 1 \\
\hline 1019 & Chamber 4 Clerks & 17 & 2 \\
\hline 1020 & Chamber 5 Associate & 12 & 1 \\
\hline 1021 & Chamber 5 Clerks & 17 & 2 \\
\hline 1022 & Chamber 5 Judge & 37 & 1 plus 2 \\
\hline
\end{tabular}




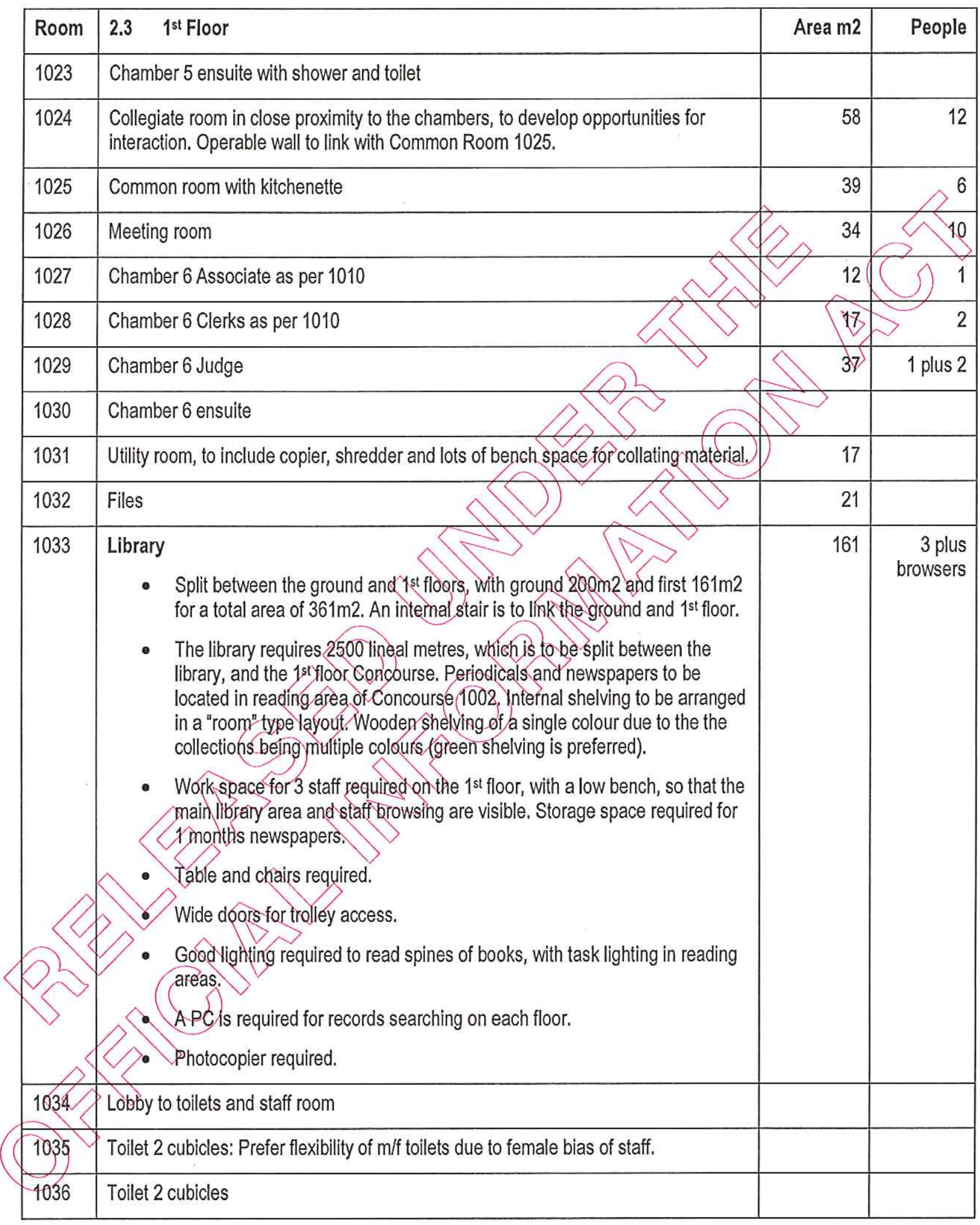




\begin{tabular}{|c|c|c|c|c|}
\hline Room & \multicolumn{2}{|l|}{$2.3 \quad 1^{\text {st }}$ Floor } & Area m2 & People \\
\hline 1037 & \multicolumn{2}{|l|}{$\begin{array}{l}\text { Staff kitchen to include: } \\
\text { - Microwave } \\
\text { - Jug/hotwater boiler } \\
\text { - Underbench fridge } \\
\text { - Oven } \\
\text { - Other }\end{array}$} & 23 & 12 \\
\hline \multirow[t]{3}{*}{1038} & \multicolumn{2}{|l|}{ Comms/patch panel room } & & \\
\hline & \multicolumn{2}{|l|}{ Cleaners room required. } & & \\
\hline & $\begin{array}{l}\text { Number of occupants: } \\
\text { The building load is not expe } \\
\text { vacated, while occupants are } \\
\text { be in the Courtroom during a } \\
\text { Total occupancy peaks are } n \\
\text { services loads will increase, } \\
\text { in the Courtroom, leaving the }\end{array}$ & $\begin{array}{l}\text { Normal business hours } \\
\text { CJ, } 1 \text { Associate, } 3 \text { Clerks total } 5 \\
\text { Qty } 5 \text { chambers with } 1 \text { Judge, } 1 \\
\text { Associate, } 2 \text { clerks total } 20 \\
5 \text { people work up to } 8 \text { prn most nights } \\
\text { 1Registrar in office, } 3 \text { staff during } \\
\text { normal business hours } \\
3 \text { during normal business hours } \\
3 \text { during normal business hours shared } \\
\text { with the OHCB } \\
35 \text { people estimated } \\
20 \% \text { or } 1 \text { day per week usage } \\
\text { Increasing up to the forecast of } 50 \% \text { or } \\
2.5 \text { days per week } \\
5 \text { Judges, } 20 \text { counsel, } 6 \text { press, } 1 \text { court } \\
\text { taker (registrar) } \\
\text { Sometimes up to } 70 \text { public and } \\
\text { additional } 30 \text { in foyer } \\
132 \text { total peak load } \\
159 \text { peak load } \\
\text { fover. } \\
\text { these limits, with some rooms being } \\
\text { nother room. For example, the Judges will } \\
\text { eir chambers are vacant. } \\
\text { deviate, while some occupied areas } \\
\text { aceasing. For example, the Judges will be } \\
\text { acant. }\end{array}$ & & \\
\hline
\end{tabular}




\section{$3 \mid 297-016$ \\ PI2 of 17}

\begin{tabular}{|c|c|c|c|}
\hline Room & 3.0 OHCB & Area $\mathrm{m} 2$ & People \\
\hline & $\begin{array}{l}3.1 \text { Basement } \\
\text { Generally restored, except for strengthening intrusion. No occupancy except } \\
\text { to view cells, and service equipment. }\end{array}$ & & \\
\hline B1 & Entry to cells. & & \\
\hline B2 & Corridor servicing cells. & & \\
\hline B3 & Security office to service cells. & & \\
\hline B4 & Cell 1 & & 2 \\
\hline B5 & Cell 2 & & \\
\hline B6 & Cell 3 & & \\
\hline B7 & Cells: Storeroom. & & \\
\hline B8 & $\begin{array}{l}\text { Cells: Plant room: To service plumbing from toilets above, along with signifficant } \\
\text { structural intervention. }\end{array}$ & & \\
\hline B9 & Cells: Storeroom: Level of intervention tba. J) & & \\
\hline B10 & Stair down from docks in No1 courtroom G13. & & \\
\hline B11 & $\begin{array}{l}\text { Stair down to strong room Whitmore st side: Heritage fabric to be retained as much } \\
\text { as possible. }\end{array}$ & & \\
\hline B12 & $\begin{array}{l}\text { Basement strong foom Whitmore St side Strengthening to include sprayed concrete } \\
\text { on inner walls. }\end{array}$ & & \\
\hline \multicolumn{4}{|l|}{$\mathrm{B} 13$} \\
\hline B14 & $\begin{array}{l}\text { Diesel generator room Whitmore St side: Strengthening to include sprayed concrete } \\
\text { on innerwalls. Strengthening to include concrete to inside of walls. }\end{array}$ & & \\
\hline Room & 3.2 Ground floor & Area $\mathrm{m} 2$ & People \\
\hline G001 & Stout St entrance & 19 & \\
\hline G002) & & & \\
\hline 6003 & $\begin{array}{l}\text { Foyer to No1 Courtroom } \\
\text { - Ventilation and heating tba } \\
\text { - Restoration as per Conservation Report and other relevant documents. }\end{array}$ & 62 & \\
\hline G004 & Lobby/lock into No1 Courtroom through double doors. & & \\
\hline G005 & Lobby into store room and single door entrance to office $\mathrm{G} 64$ & & \\
\hline G006 & Store room to Stout St & 10 & \\
\hline
\end{tabular}




\begin{tabular}{|c|c|c|c|}
\hline Room & Ground floor & Area $\mathrm{m} 2$ & People \\
\hline \multicolumn{4}{|l|}{ G007 } \\
\hline \multicolumn{4}{|l|}{ G008 } \\
\hline \multicolumn{4}{|l|}{ G009 } \\
\hline G10 & Interview room to Stout St & 10 & 2 \\
\hline G11 & South stair to gallery & & \\
\hline $\mathrm{G} 12$ & Corridor south side of No1 Courtroom & & \\
\hline $\mathrm{G} 13$ & $\begin{array}{l}\text { No1 Courtroom: } \\
\text { Expected usage } 1 \text { day per week and to house maximum of } 2 \text { judges, } 30 \text { public, } 10 \\
\text { counsellors, } 10 \text { jury including press, possibly } 5 \text { at centre table. } \\
\text { Restoration as per Conservation Report, and other relevant doeuments. } \\
\text { No public access to the gallery. }\end{array}$ & 143 & 57 \\
\hline G14 & Corridor north side of No1 Courtroom & & \\
\hline G15 & Corridor running north/south between No1 \& No2 Courtrooms. I & & \\
\hline G16 & Corridor south side of No2 Courtroom & & \\
\hline $\mathrm{G} 17$ & $\begin{array}{l}\text { No2 Courtroom: Retiring Room: } \\
\text { Expected usage } 2 \text { days per week, and to hold regular yideo conference with up to } 10 \\
\text { present, and monthlyjudicial dinners, with a maximum of } 30 \text { people. } \\
\text { Restoration as per Consenvation Report and other relevant documents. }\end{array}$ & 90 & 30 \\
\hline G18 & Corridorriorth side of No2 Coufitroom, and to service CJ Administration. & & \\
\hline G19 & Corridor running north/south to Lambton Quay side of No2 /Courtroom. & & \\
\hline $\mathrm{G} 20$ & Office corner of Ballance and sfout. & 18 & 1 \\
\hline 6212 & Byblic toilet access. & & \\
\hline 622 & Meeting room 2. To include a kitchenette for tea making facilities. & 20 & \\
\hline \multicolumn{4}{|l|}{ G23 } \\
\hline G24 & Meeting room 1 & 28 & 8 \\
\hline G25 & Toilet with shower for counsel & & \\
\hline G26) & Stair down to cells & & \\
\hline G27 & Store room & & \\
\hline G28 & Stair up to 1 st floor & & \\
\hline G29 & $\begin{array}{l}\text { Comms room of approx } 10 \mathrm{~m} 2 \text {. To house equipment with Supreme Court, CJ Admin } \\
\& \text { other uses. Allow } 3 \text { racks. }\end{array}$ & 10 & \\
\hline G30 & & & \\
\hline
\end{tabular}




\section{$31297-016$ \\ P14 of 17}

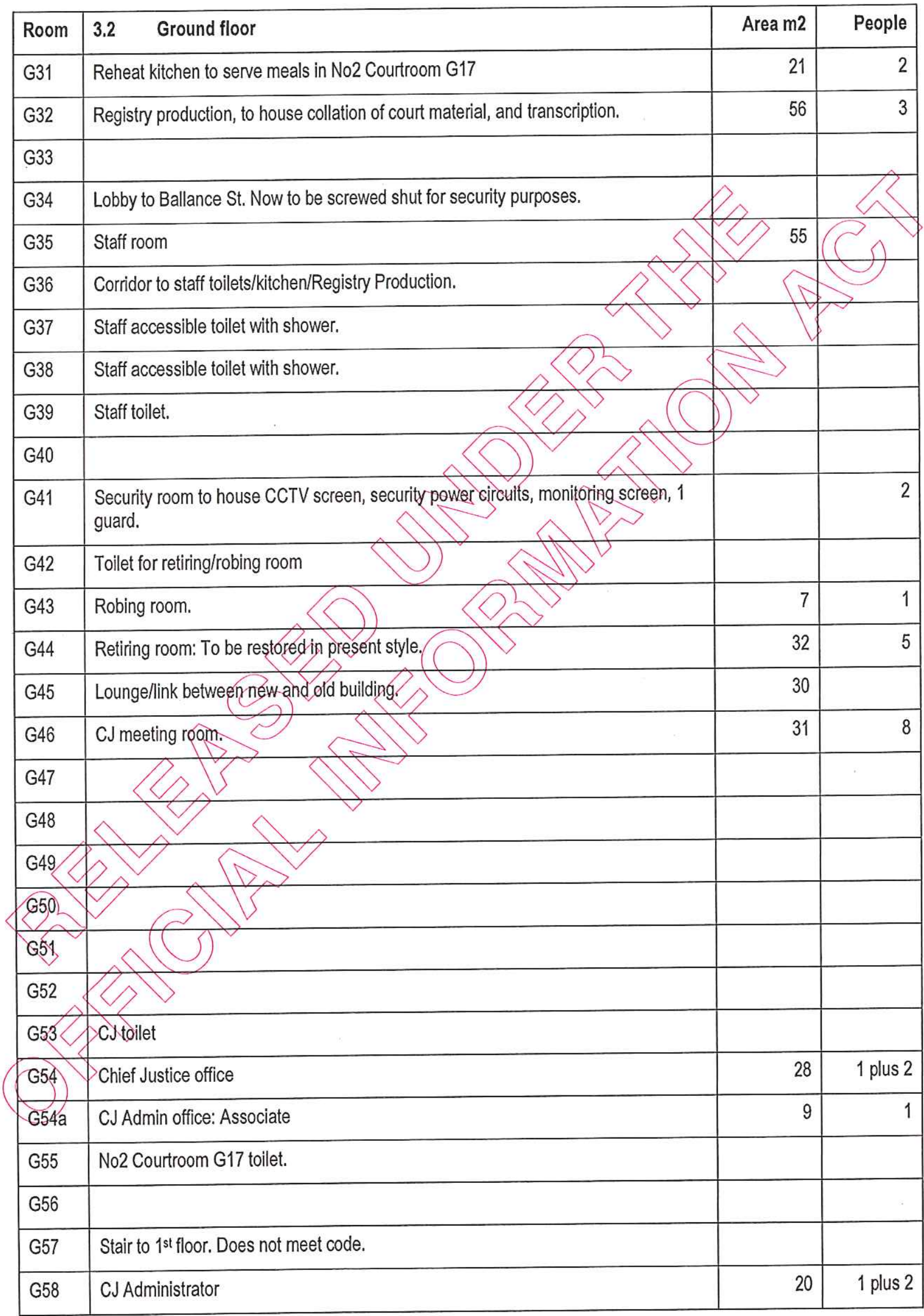




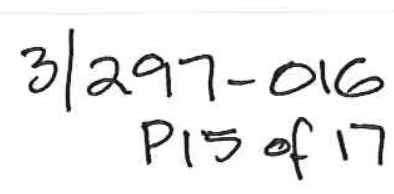

\begin{tabular}{|c|c|c|c|}
\hline Room & 3.2 Ground floor & Area $\mathrm{m} 2$ & People \\
\hline G59 & Lobby between CJ Admin offices & & \\
\hline G60 & CJ Admin staff & 47 & 4 \\
\hline G61 & Stair to 1 st floor & & \\
\hline G62 & CJ Admin office/storage & 37 & \\
\hline G63 & Strong room with stair down to basement storeroom. & & \\
\hline G64 & Whitmore St Office: Unallocated open plan & 128 & 9 \\
\hline \multicolumn{4}{|l|}{ G65 } \\
\hline G66 & CJ Admin lobby & $>$ & \\
\hline G67 & Whitmore St Office: Unallocated & 18 & 1 \\
\hline \multicolumn{4}{|l|}{ G68 } \\
\hline \multicolumn{4}{|l|}{ G69 } \\
\hline G70 & Ballance St public toilet & & \\
\hline G71 & Ballance St public toilet accessible. & & \\
\hline G72 & Ballance St public to & & \\
\hline G73 & No2 Courtroom G & & \\
\hline \multicolumn{4}{|l|}{ G74 } \\
\hline \multicolumn{4}{|l|}{ G75 } \\
\hline \multicolumn{4}{|c|}{ Room 3 . } \\
\hline F01 & Office open plan & 41 & 3 \\
\hline \multicolumn{4}{|c|}{ Fo2 $\mathrm{C} \mathrm{C}^{\mathrm{V}}$} \\
\hline $\mathrm{FOS}$ & Stairs down to CJ Admin G57 & & \\
\hline F04 & store & 11 & \\
\hline \multicolumn{4}{|c|}{ Fo5 } \\
\hline \multicolumn{4}{|c|}{ F06) } \\
\hline F07 & Link between north and south side 1 st floor. & & \\
\hline \multicolumn{4}{|l|}{ F08 } \\
\hline \multicolumn{4}{|l|}{ F09 } \\
\hline $\mathrm{F} 10$ & Office Ballance St West & 70 & 3 \\
\hline
\end{tabular}




\section{$3 \mid 297-016$ \\ P16 of 17}

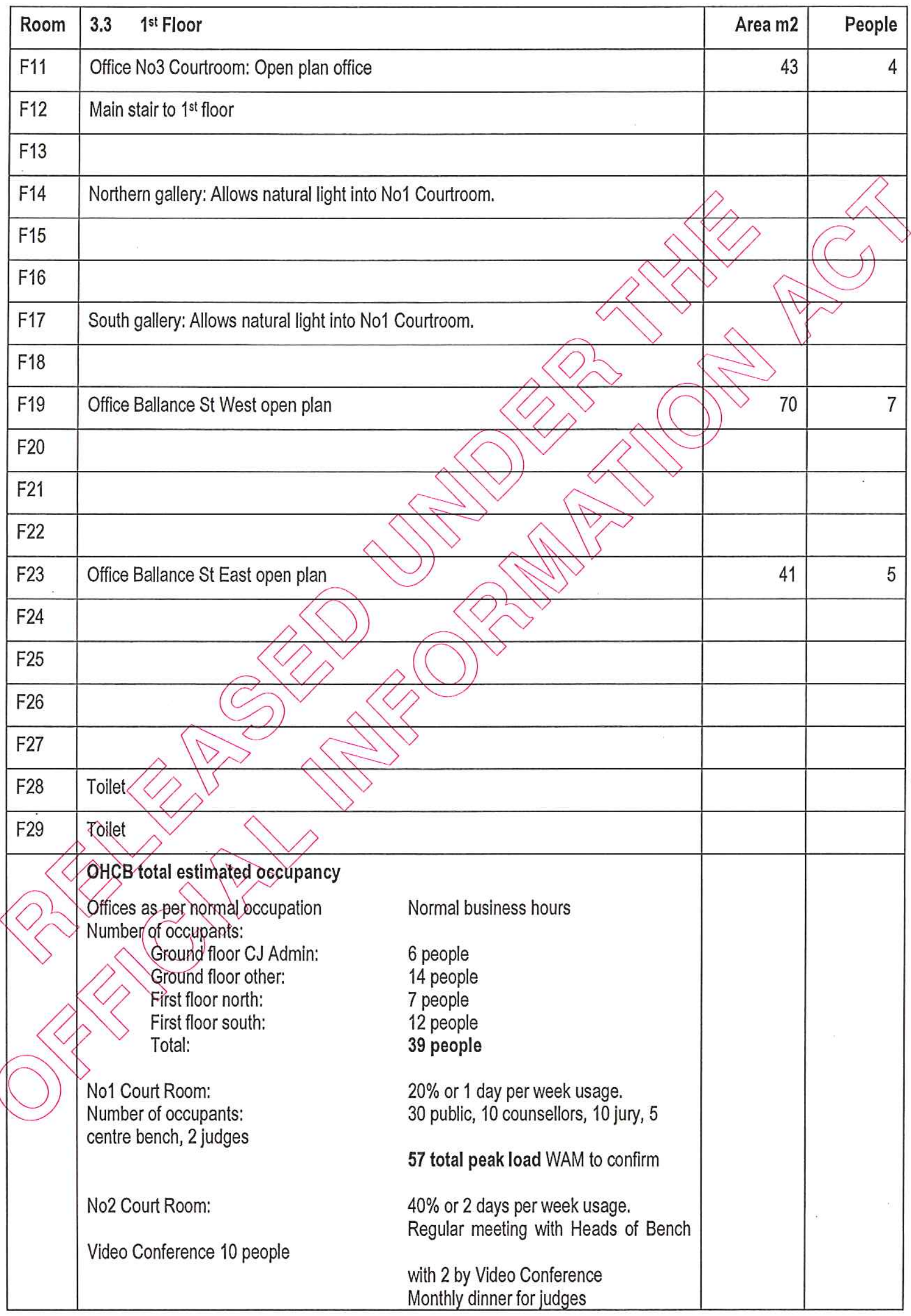




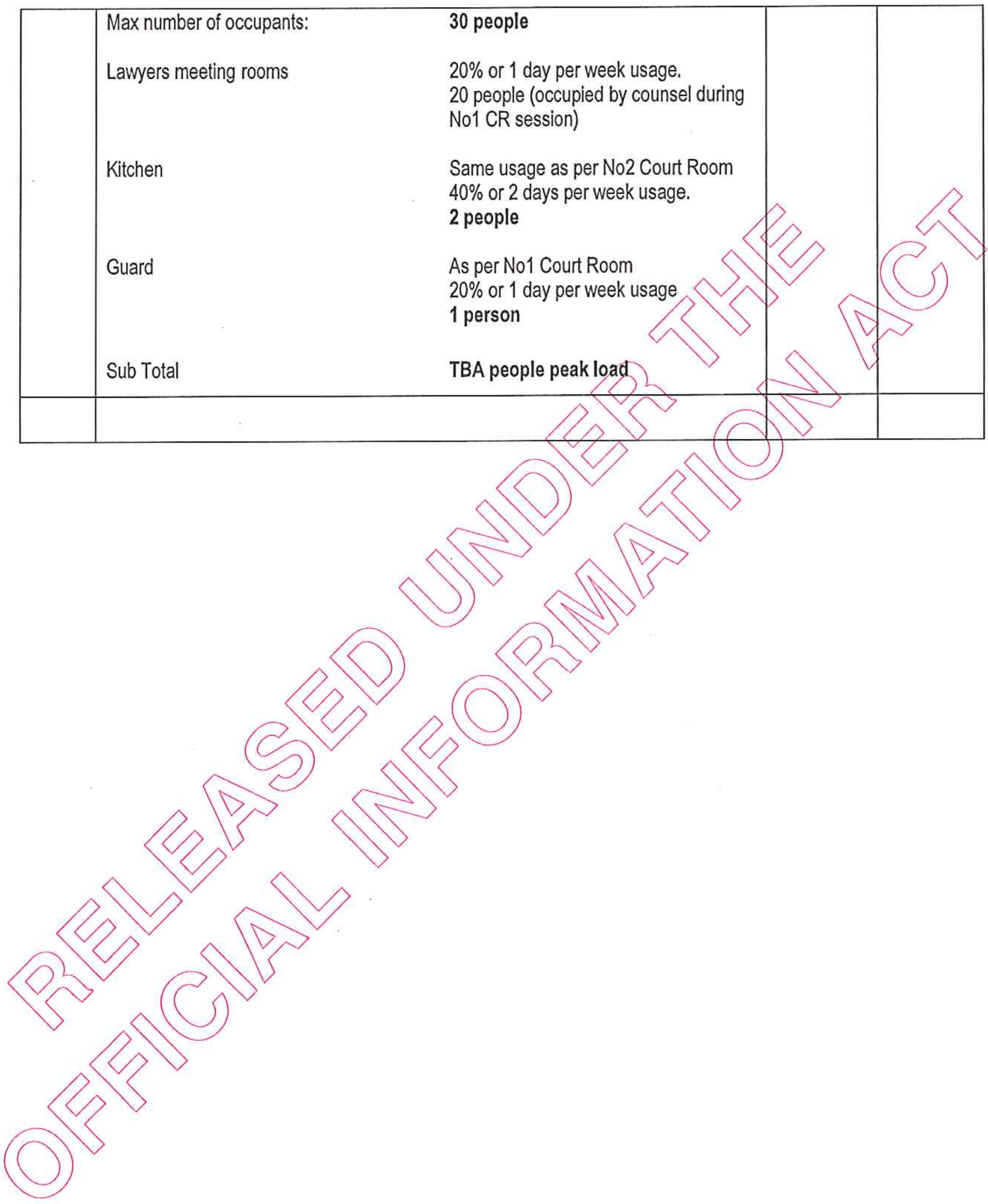


Appendix III

Supreme Court Conservation Report (excerpts)

Prepared by Chris Cochran for The Ministry of Justice 


\subsection{Description}

\section{Structure}

The Supreme Court building is of solid masonry construction (ie brick walls with no cavity). The foundations are concrete piles formed by "... hollow iron piles being driven into the ground and then filled with cement, ${ }^{101}$ after which they are withdrawn, leaving the cement piles in the ground. Upon these are formed the cement foundation walls, which are very thick and substantial. ${ }^{102}$ The brick walls rise from these concrete foundations; they have cement-based mortar, and they are finished both outside and inside with plaster. It is thought that there is no tensile strengthening (in the form of 'bond iron') set within the walls, although contemporary accounts suggest that such techniques were in use in Wellington at about this time.

The floor structure is timber, with heart matai tongue and groove flooring in most spaces. The roof is timber framed, with heavy trusses spanning the main courtroom in a northsouth direction; the original roof sheathing was slates, the last of these being replaced in 1960 with corrugated asbestos cement.

\section{Plan Layout}

The original plan was symmetrical about the Stout Street elevation, but the additions of 1907 and 1913, on both the north and south sides of the building, altered the symmetry. On the main axis, starting from Stout Street, is the main entrance, the vestibule and the main No 1 Courtroom, the latter two spaces rising over 9 metres through the height of the two floors; a smaller police court (later known as the No 2 Courtroom) ran in a north-south direction behind the main court room.

A corridor ran around the three sides of the main court room, giving access to the offices disposed along both sides of the building: deputy registrar, jury room, magistrates court office and bailiff's office on the north, and sheriff, registrar, witness room, robing room, grand jury room and library on the south. Beyond the smaller courtroom at the west end of the building was a suite of three judges' rooms and two secretaries' offices. The several additions of 1907 and 1913 expanded the facilities for registrar, library and judges.

The first floor consisted of two areas: there was an arbitration court and an apartment for the 'housekeeper' in the north-west corner, while in the south-west corner it appears that the grand jury room and the library rose through both floors. A floor was put in however, probably early in the life of the building. Each of the first floor areas were independent and were accessed from different staircases.

The original access to the basement was via a stair down from the outside (south side) of the building; there were five cells with a passageway and stair leading directly up to the dock in the middle of the main court room. On the north side there was another basement space, used for storage, with a part of it later used for heating plant.

The early room layout and functions of spaces can be established from the original floor plans that still exist, reference WDO 20674/2869, and more detail is given in Section 3.3 Schedule of Spaces.

101 Not literally cement, but concrete.

102 New Zealand Mail, 18 October 1879 


\section{Finishes}

The exterior of the building would originally have been left as unpainted plaster, of a light grey colour. (This, coincidentally, can still be seen in one small area of wall of the 1913 addition in the north-west corner, facing Lambton Quay, a part that has been covered by an adjoining building.) It is not known when the building was first painted.

All the joinery, exterior and interior, is timber. The exterior joinery, double-hung windows and panelled doors, is painted, while much of the interior timber still has its original natural finish. Some of the interior work is of exceptional quality, in particular the curving double stairs in the vestibule leading to the public gallery, and the timber work of the No 1 Courtroom; this includes panelling, a carved wall frieze, and the judge's bench and canopy. Similar panelling, not as elaborate, adorns the walls of the No 2 Courtroom. Elsewhere in the original part of the building the walls are solid plaster, with a tongue and groove boarded dado and high moulded skirting. In some spaces, the original dado exists under a later anaglypta finish.

Doors are panelled, those of special status (to the No 1 Courtroom for example) having heavy bolection mouldings; some apparently flush doors are the original doors covered in hardboard. Kauri and rimu are the main timbers used in the interior finishing.

Ceiling finishes were lath and plaster, now largely replaced with sheet material. The main spaces have large-scale coved cornices. Some spaces have modern lowered ceilings, the No 1 Courtroom for instance, with the original ceiling still intact in the void. The Judges Library, G20, is unusual in having a timbered ceiling.

A surprising amount of original fabric has survived in the building. Modernisation has occurred on a large scale in two main areas, the suite of judges chambers at the west end of the building (G41 to G46), and in the No 3 Courtroom (F11) on the first floor. Along with the ceiling of the No 1 Courtroom, these spaces now have a distinctly $1960 \mathrm{~s}$ character.

\section{Style}

The style of the building is strongly Classical, both in the strict symmetry of the original composition and in the treatment of the exterior form and decoration. The Classical style was commonly used in the 19th century for even modest court and police buildings, since it was judged to impart a suitable aura of authority and gravitas to the buildings from which justice was dispensed.

The overall plan is a T-shape, each arm of the $\mathrm{T}$ originally being finished with a triangular pediment rising above the roof parapet; there was also a fourth pediment on the west elevation above Courtroom No 2. These pediments, decorated with prominent acroteria, were removed in 1956. The ground floor is heavily rusticated, the plasterwork detailed to give the impression of heavy stone construction; the round-headed windows have keystones and there is an open balustrade above. The first floor has a plain plaster finish to the wall surfaces, which is divided into bays by pilasters and attached columns with capitals in the Corinthian style. The windows between have triangular pediments supported on either side by corbels. A bracketed cornice at roof level has now been much reduced by the removal of pediments and balustrade.

This ornate treatment was applied to the whole of the exterior except for the walls of 
the No 2 Courtroom and the wing containing the judges chambers, which are quite unadorned. These are the least seen parts of the exterior, being tucked between two storey wings in the case of the No 2 Courtroom, and set back from the street in the case of the judges chambers. An unexplained feature of the wing containing the judges chambers is the remnant of a parapet on the east side of the block returning just a short distance on the south. It was perhaps cost saving in a relatively unseen part of the building.

The Supreme Court relates well to the Government Buildings opposite because of the common origin of the detailing, both buildings exhibiting a competent and original treatment of the Classical style.

\section{Additions}

The major additions of 1907 and 1913 followed the style and detailing of the original work, so that, apart from the a-symmetry caused to the form of the building, they are hard to detect. The addition of 1981 made no pretence to match the original work, and is in a utilitarian style of no architectural interest. Other recent and generally minor alterations have been inappropriate in the context of the high quality finishes of the original building. Although modifications carried out to the offices of the Chief Justice (space G44 etc) are also different in character, they are quality work of their time and have some aesthetic value.

\section{Services}

The Supreme Court was originally lit by gas, and remnants of the reticulation system can still be found in the building. Natural light to the main courtroom was via two sets of windows (separated by a 'corridor') at first floor level, and also from a central light in the ceiling. This skylight incorporates white plaster walls designed to reflect diffused light into the courtroom through the ceiling. This has been covered over, most recently by the new ceiling installed in 1962, but the structure of the skylight is still visible in the ceiling void. There were also floor lights in the 'corridors' which lit the ground floor corridors around the No 1 Courtroom.

Heating of all but the two courtrooms was originally by open fires, and fireplaces remain in some spaces to the present day, although they are long disused and the chimneys have been removed.

Ventilation of the two courtrooms was by an ingenious system of large $(300 \mathrm{~mm}$ diameter) glazed earthenware pipes run in trenches from vents in the perimeter foundation walls to ornate cast iron grilles (some extant, but covered over) in the rooms. Thus cool outside air was introduced near floor level and slowly rose as it warmed; the system was controlled by dampers. Uninsulated heating pipes suggest that the air could be warmed as well, although this feature may have been installed with the existing boiler in $1930 .^{103}$

103 For a full explanation of the original ventilating and heating system, see The New Supreme Court, Building Feasibility Report for the Department for Court, Promanco Kenman, November 2002, Section 12 by Norman Disney and Young. 


\section{Drawings}

Following are six architectural drawings that help explain the early history and form of the building. Aperture cards of the drawings are held by the Wellington office of Opus International.

\begin{tabular}{|c|c|c|}
\hline $\begin{array}{l}\text { Drawings } \\
1,2 \text { and } 3 \\
1886 / 1903 \\
\text { Pages } 60,61 \\
\text { and } 62\end{array}$ & $\begin{array}{l}\text { Ground Floor } \\
\text { Plan } \\
\text { First Floor Plan } \\
\text { Section }\end{array}$ & $\begin{array}{l}\text { The file card says this set of three drawings shows the } \\
\text { building "As existing December } 1903 \text { " and that they were } \\
\text { compiled from drawings dated } 1886 \text {. Early room uses etc } \\
\text { have been taken from these drawings and are referred to as } \\
\text { original, but it is entirely possible that some changes were } \\
\text { made between } 1881 \text { and } 1886 / 1903 \text {. These are the earliest } \\
\text { drawings presently known to exist. }\end{array}$ \\
\hline $\begin{array}{l}\text { Drawing } 4 \\
\text { Drawing } 5 \\
1907 \\
\text { Page } 63 \\
\text { and } 64\end{array}$ & $\begin{array}{l}\text { Alterations and } \\
\text { Additions }\end{array}$ & $\begin{array}{l}\text { These are the drawings for the two } 1907 \text { additions, in the } \\
\text { north-east corner (registrar's office) and on the south side } \\
\text { (library). }\end{array}$ \\
\hline $\begin{array}{l}\text { Drawing } 6 \\
1913 \\
\text { Page } 65\end{array}$ & Additions & $\begin{array}{l}\text { This is the drawing for the } 1913 \text { addition in the north-west } \\
\text { corner. }\end{array}$ \\
\hline
\end{tabular}




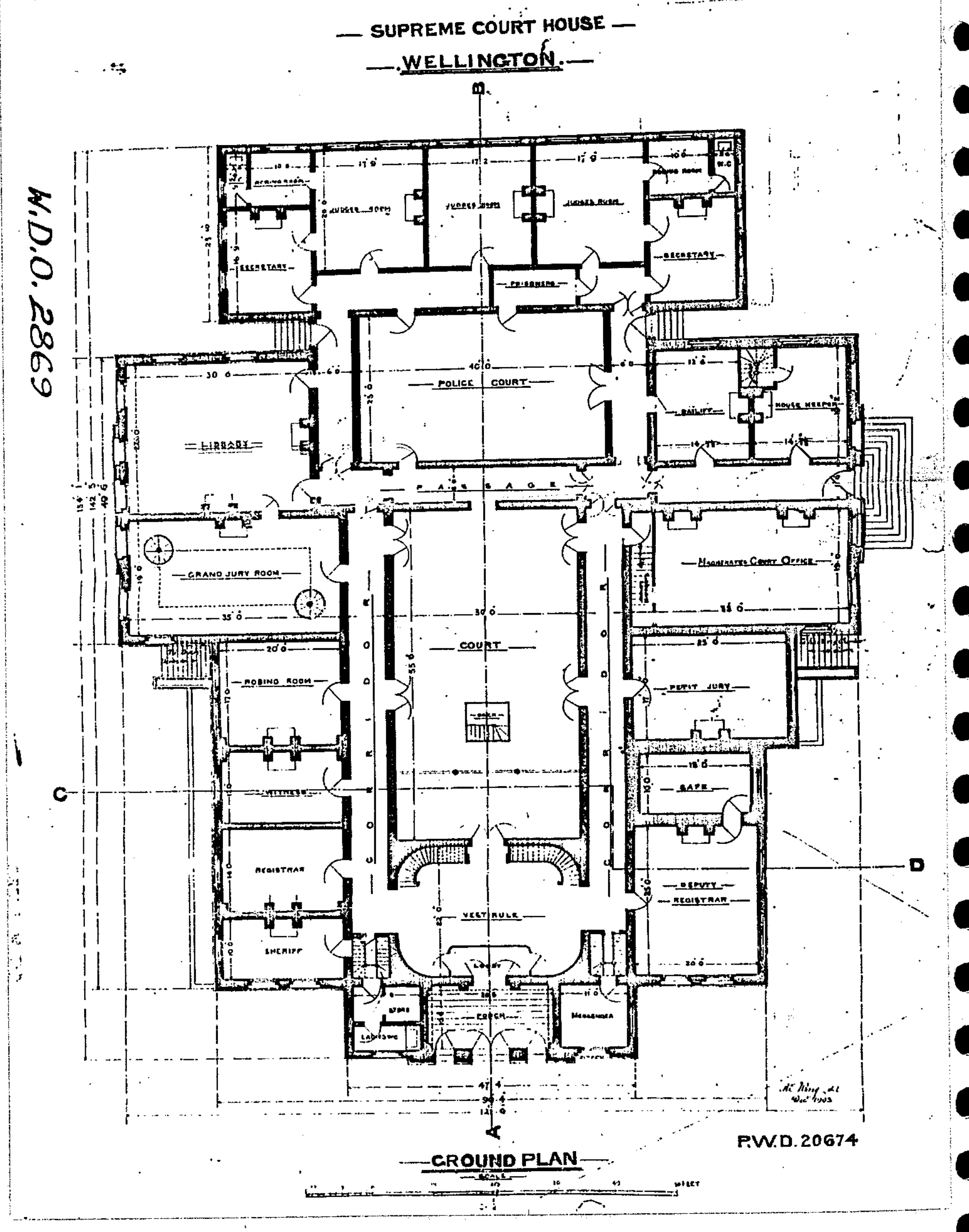


WELLINGTON

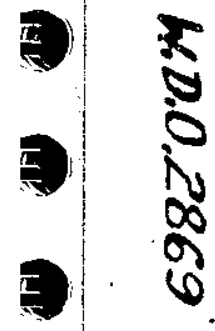

$x$
0
0
0
6
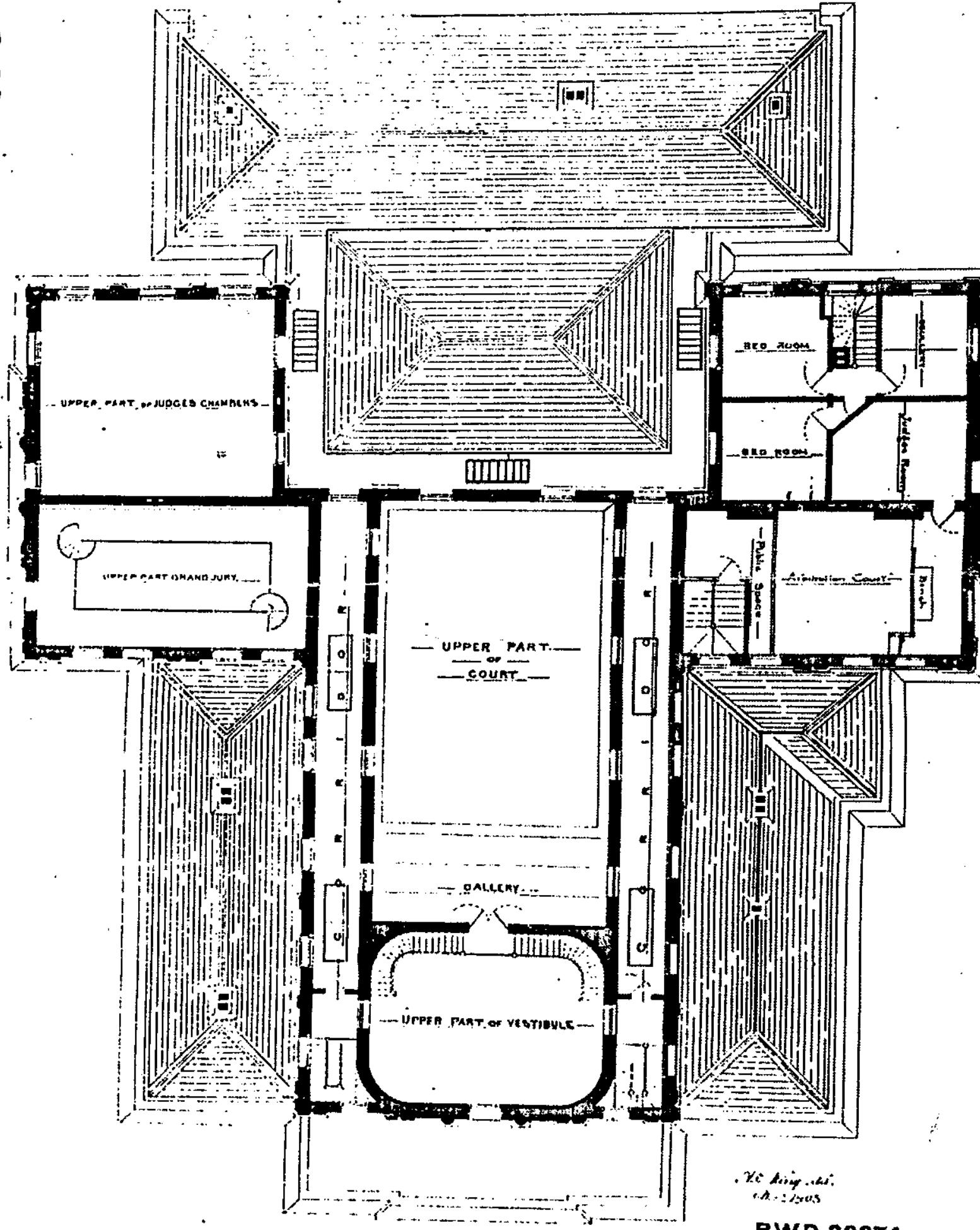

- xe histant

P.W.D.20674

FIRST FLOOR PLAN. 


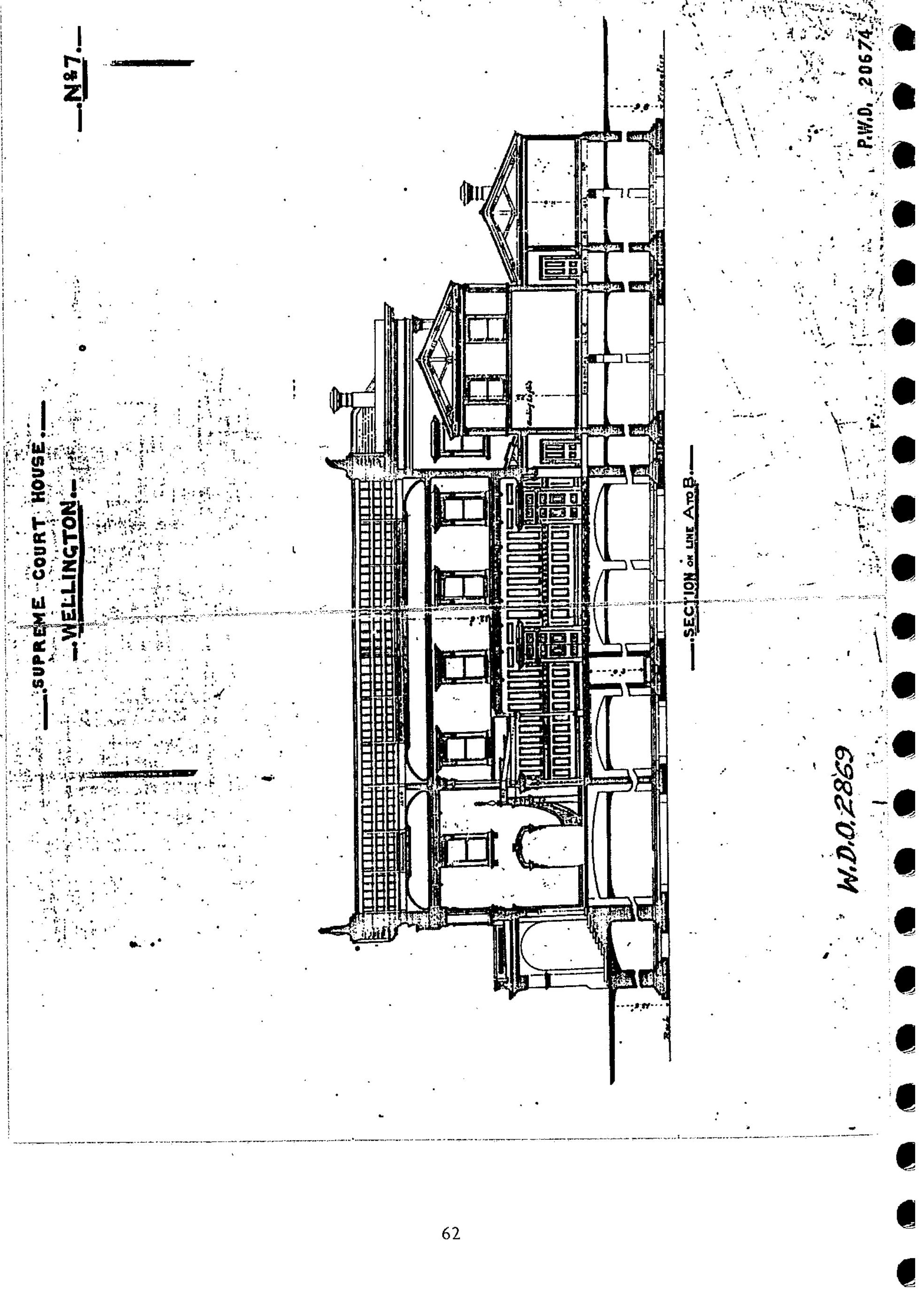




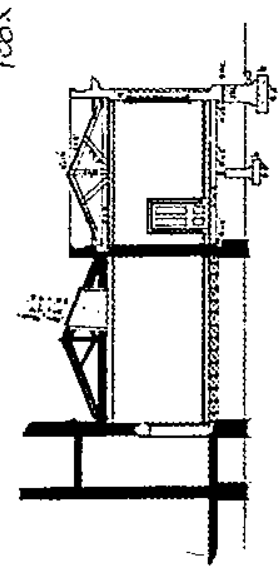

数害

3
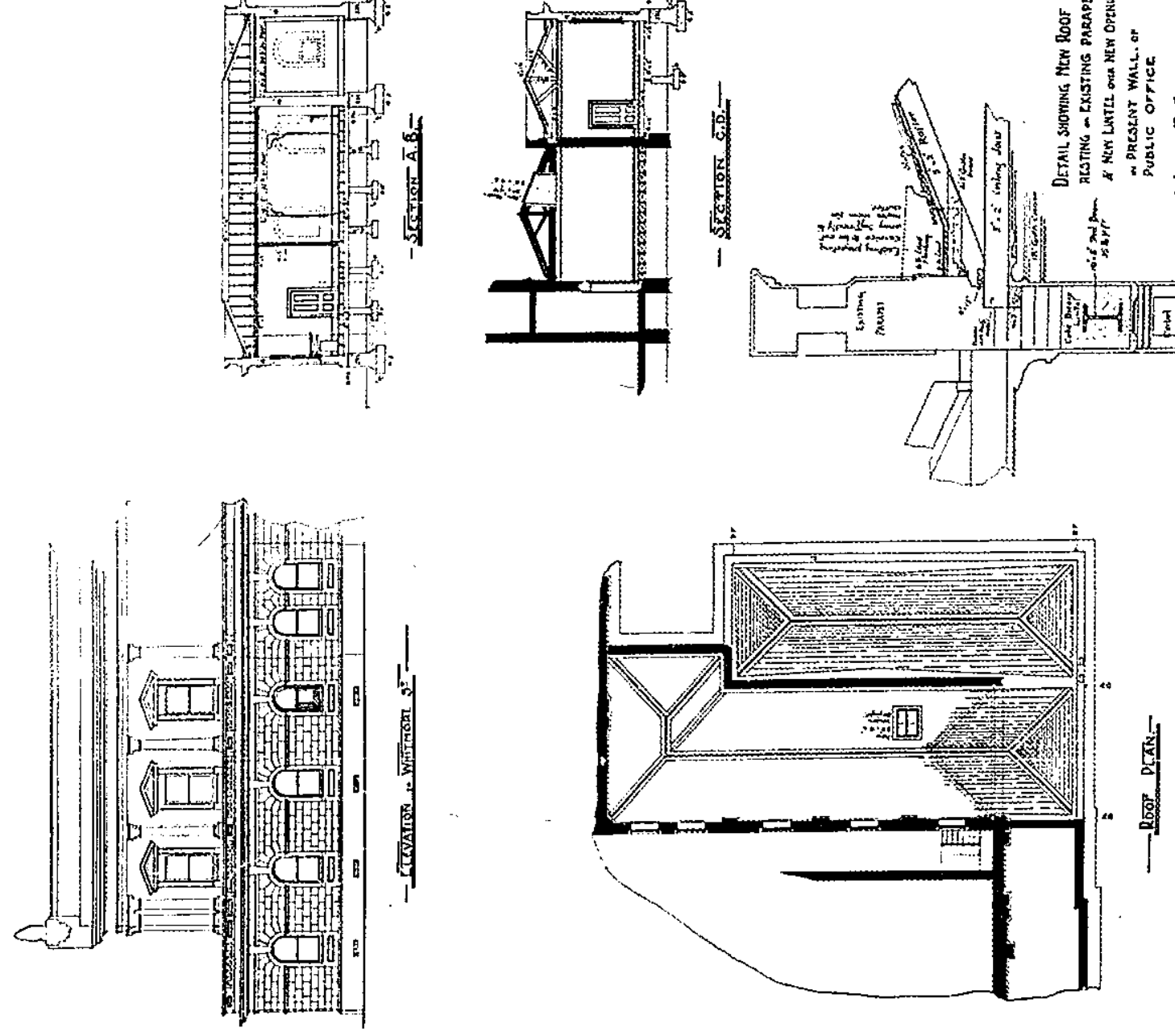

点喜

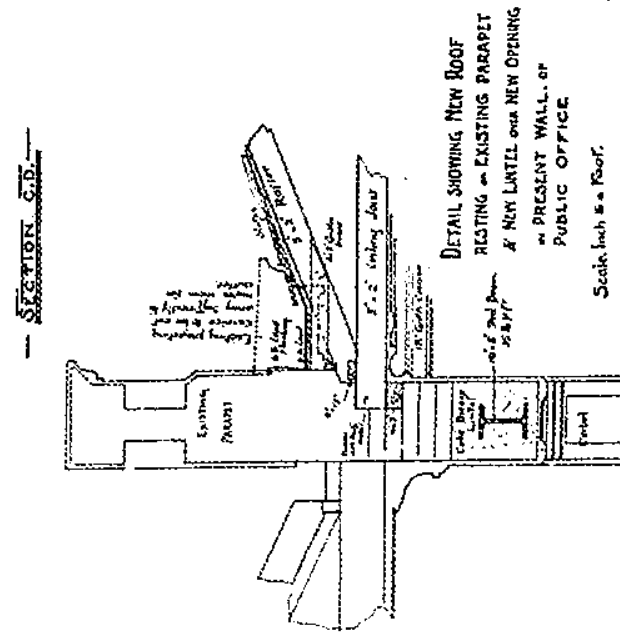

$=-$
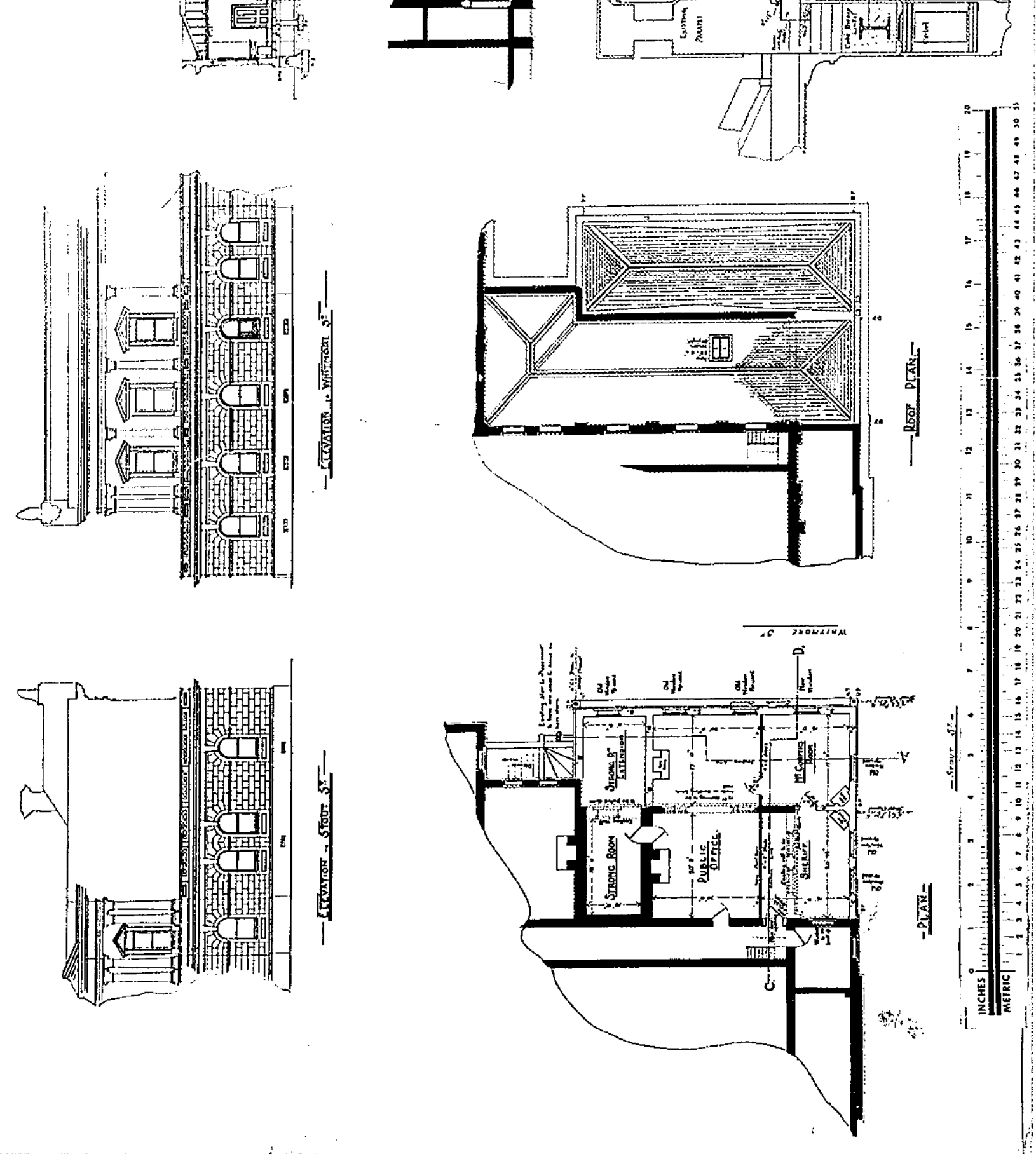

?

)

)

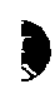




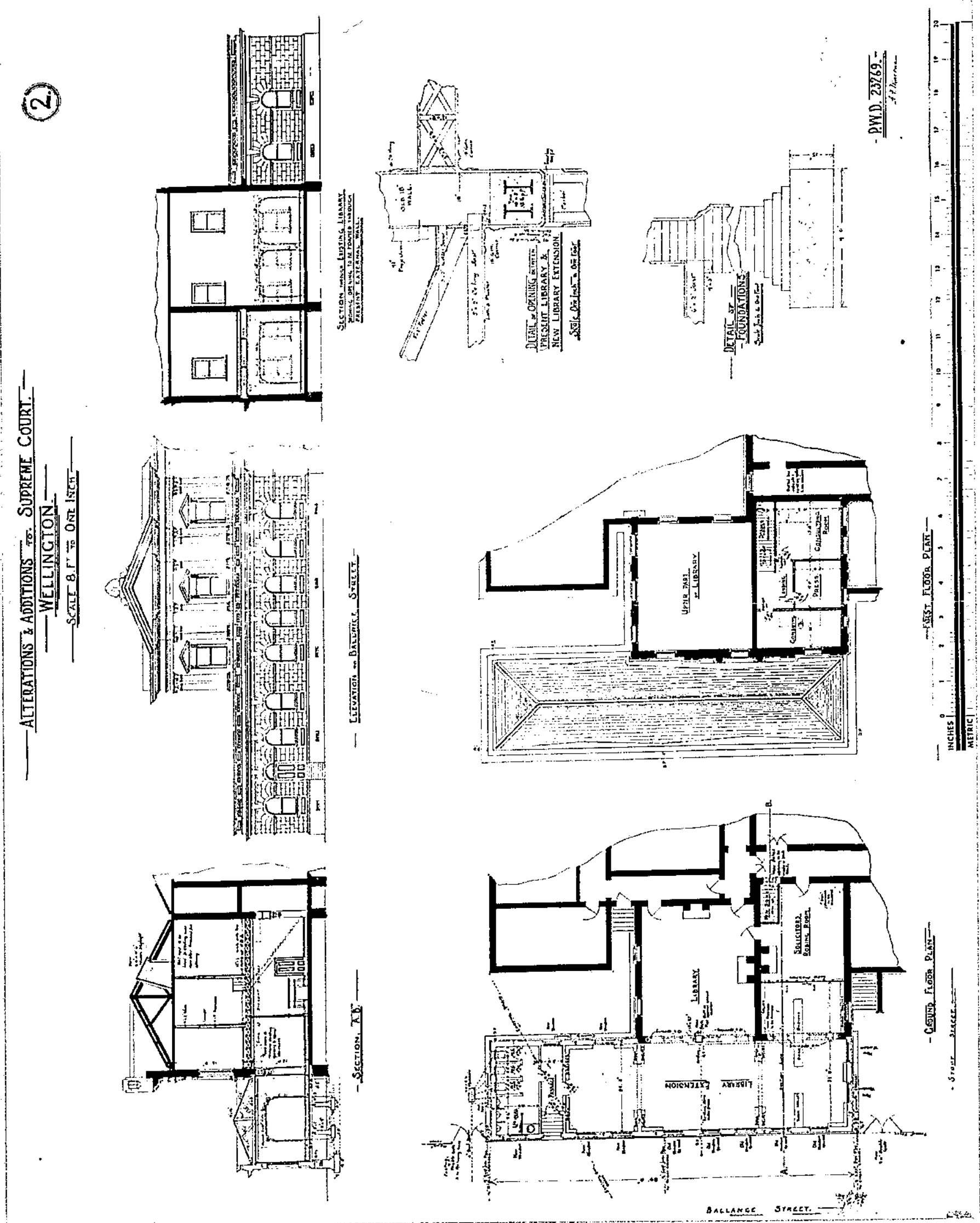



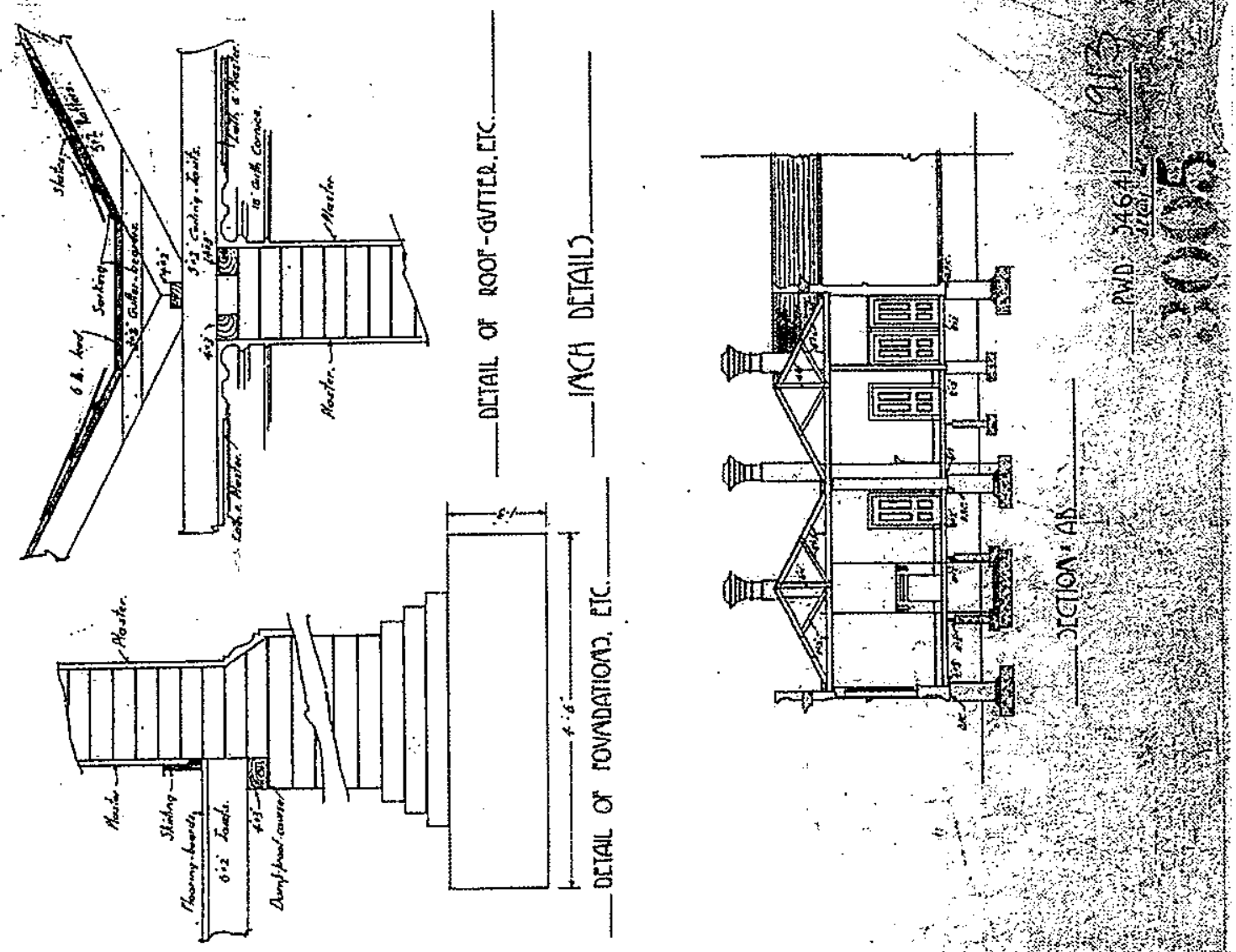

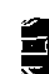

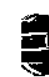

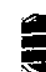

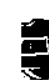

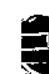
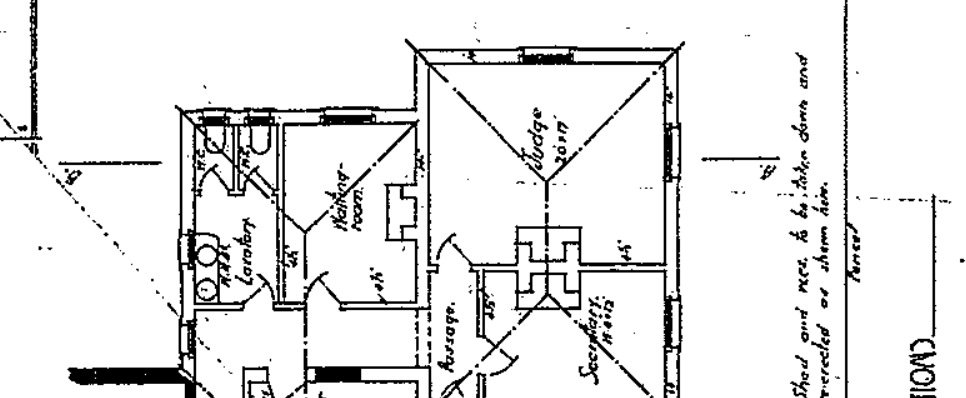
ait:
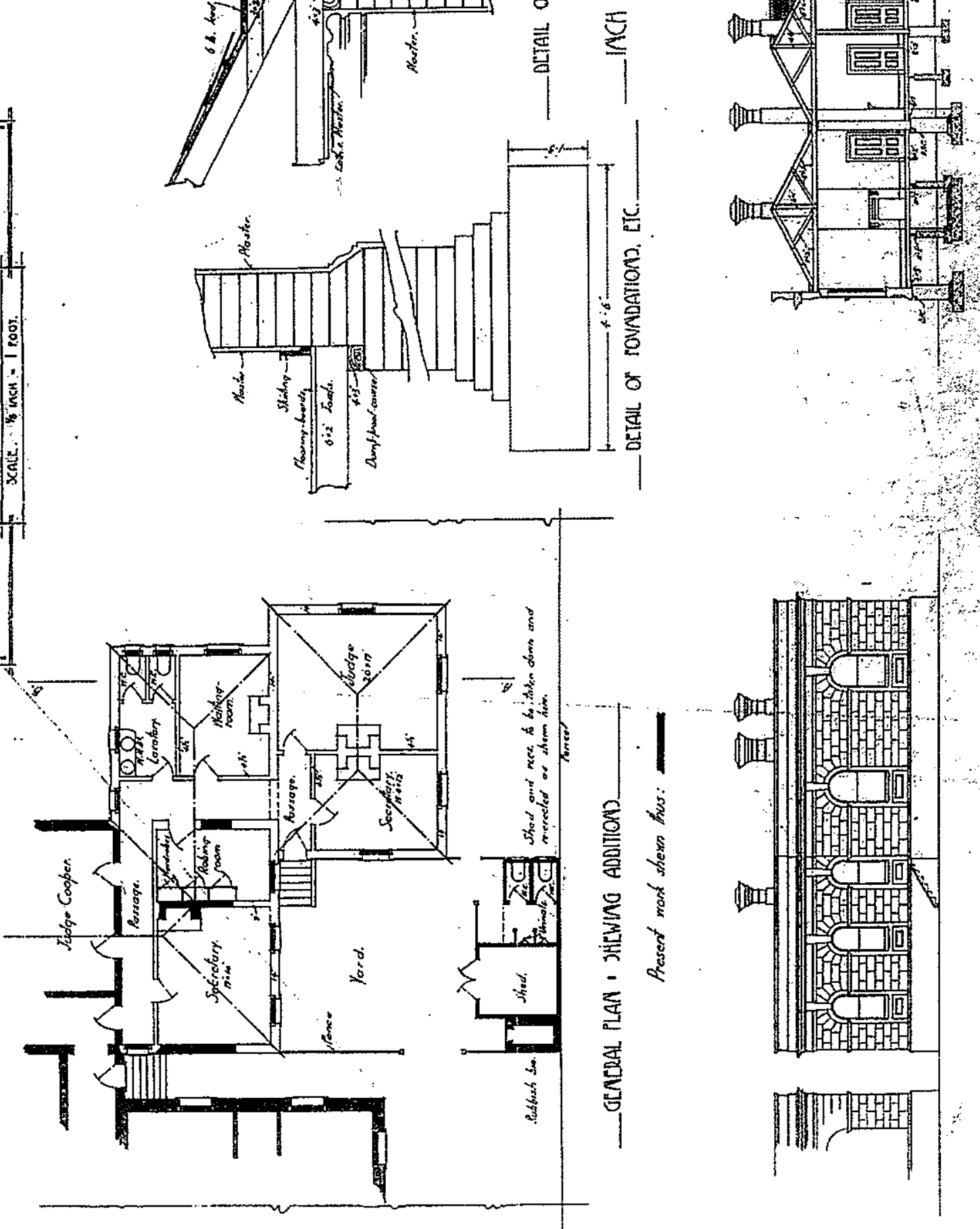

$+5$
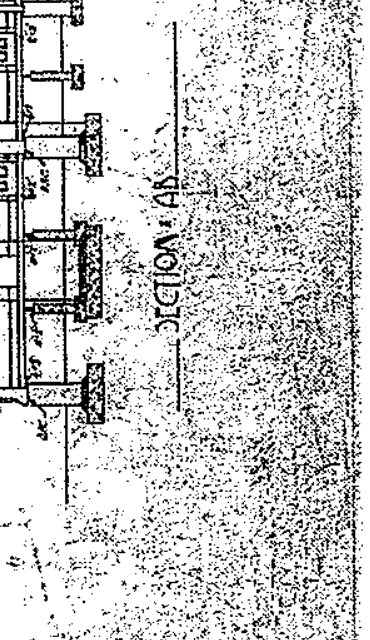

a

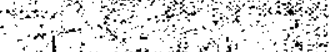

כ

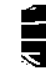

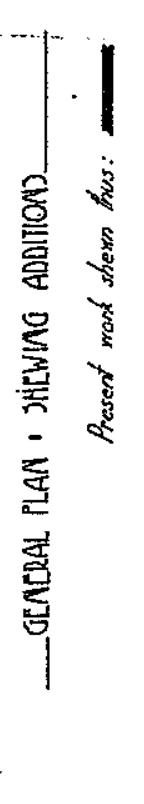




\subsection{ASSESSMENT OF SIGNIFICANCE}

This section includes a general statement of the cultural heritage significance of the Supreme Court, followed by an assessment based on the criteria found in the Historic Places Act; these however, are grouped under the four headings of historic, social, aesthetic and scientific value as recommended in Guidelines for Preparing Conservation Plan, NZHPT, 2000.

\subsection{Statement of Significance}

The former High Court, known as the Supreme Court until 1980, is a building of national significance. It provides a continuous link with the administration of justice in New Zealand over 112 years. It has been the setting for many famous and infamous cases in New Zealand legal history, and it has been presided over by all the Chief Justices of New Zealand between 1881 and 1993.

The building was designed by the Government Architect of the day, P F M Burrows, and was opened in 1881. It was the last major building of a vigorous programme of construction by central Government in Wellington in the 1870 s, the only other one remaining being Government Buildings of 1876. It was also the first major public building constructed in masonry in the capital.

For these reasons, and for the fact that it retains its integrity as a very important public building of the colonial period, it has a national significance which is reflected by its registration as Category I under the Historic Places Act, and by its listing on the Wellington City District Plan.

\section{Historic Value}

Values associated with particular events or uses that happened at the place, and which have importance for their impact on the community.

The history of the Supreme Court illustrates many of the changes and developments in New Zealand's social, judicial and government history. The building has been the setting for many of the most important legal cases in New Zealand history. A wide variety of people: humble and important, famous and infamous, have had connections with the building and this diversity has contributed to the richness of its history. It has been presided over by all the Chief Justices of New Zealand between 1881 and 1993, and many famous lawyers and their clients have appeared in the courtrooms in the building.

Its place in history is neatly reinforced by the names of the three streets that it fronts : Ballance, Premier in 1891-93; Stout, Attorney-General and Premier 1884-87, and Whitmore, Colonial Secretary 1877-79, all had some involvement with the building. It was the first of a number of justice-related buildings on this city block, later ones being the Wellington Central Police Station, the Magistrates Court and the Court of Arbitration; ${ }^{104}$ with the District Court opposite on Whitmore Street, the area is still pivotal today in justice history.

104 The lower parts of the walls of these buildings were left standing when the buildings were demolished; they presently form the outer edge of the of the park bounded by Ballance Street, Lambton Quay, Whitmore Street and the 1981 addition to the Supreme Court. 
Other court buildings in New Zealand of comparable historic importance are the Supreme Court building in Auckland, 1865, still in use (with major modern additions), and the former Napier Courthouse, 1875, in use as a court until 1988 and now regional offices of the Department of Conservation.

\section{Social Value}

Values associated with the use of the place; what it means to people, and the spiritual, artistic, traditional or political values that the place may embody.

The Supreme Court building is high in the public consciousness, because it has been the setting for many important legal cases, some of them of very high profile and interest. Judicial decisions made in this building have affected the lives of very many people, both as individuals in particular cases, and as citizens of the country in cases that have had far-reaching effects on New Zealand society. The building has symbolic and cultural value for these reasons, and political value for the role it has played in our democracy in interpreting the laws of the country.

Social values have declined somewhat since the building has been empty and unused since 1993, but its important social role is soon to be re-established.

\section{Aesthetic Value}

Values associated with the formal qualities of the fabric of the place and its setting; with style, form, scale, colour and texture, and with ones emotional response to the aesthetic qualities.

The Supreme Court has national importance as the work of a significant 19th century architect, P F M Burrows. It ranks with Mt Eden Prison as his best surviving building.

The building has a strong Classical character, determined by the rustication of the ground floor, the first floor pilasters and pedimented windows, and the bracketed cornice at roof level. The main interior spaces, the entrance and main court room, remain in largely unaltered form; they are two storeys high and both contain joinery of exceptional quality in New Zealand native timbers. They are two of the most important 19th century interiors in New Zealand. Period finishes remain in a number of the smaller spaces, so that the building is a very complete and rare example of colonial architecture in New Zealand. It is an important representative example of both building in the Classical style, and a 19th century courthouse.

The townscape value of the building is high, since it occupies a prominent central city site bounded by streets on three sides. It is in an area that includes a number of historic buildings. In particular it has a very compatible neighbour to the north, Government Buildings of 1876; both these buildings have common Classical detailing. Further to the north, the Railway Station forms a strong edge to the local environs. The Supreme Court is also seen in conjunction with other Government buildings to the west; they include the Beehive, Parliament and beyond to the Parliamentary Library.

Its setting to the east and south includes the Mission to Seamen Building and the Departmental Building in Stout Street, and the District Court in Whitmore Street (this is a modern structure incorporating the Classical façade of a building of 1909). Although a variety of architectural styles are exhibited in these buildings, they form a coherent historic area based on the curve of the shoreline of Lambton Quay with rising ground 
behind, and the flat grid-pattern of streets of some of the earliest reclaimed land in the city. This has always been a nodal point in the growth of Wellington.

The width of Whitmore Street and Lambton Quay, the open space around Government Buildings, and the park to the west of the Supreme Court, all mean that the Supreme Court is well seen from the north and west, and from the area around the Beehive and the Cenotaph. Views from the west are however, constricted by the ivy covered wall of the 1981 addition, and the west elevation of the main part of the building is seen only obliquely. Despite this, the building is an integral part of the Government Centre, visually connected to many of its most important buildings, and also to the commercial high-rise landscape of Lambton Quay.

\section{Scientific Value}

Values associated with building materials and technology, with structure and services, and with evidence of past use, especially as may be revealed using archaeological techniques.

The most significant technological value of the building derives from it being the first major public building in masonry in Wellington. Following earthquakes in 1848 and 1855 , timber was the main building material in the capital city until the 1880 s; this building marks the transition of timber to masonry for important buildings in the capital city. For this reason, the structure of the building and its brickwork is of particular interest.

It is rare for any public building of this age in New Zealand to be in such authentic form. Because of this and the survival of a significant amount of the original fabric, there is also technological value in the plasterwork, timber joinery and timber finishes. There is also significant technological interest in the lighting and ventilating systems which were purpose-designed and innovative for the time. The building is the repository of a fund of information about materials, techniques and building trade practice of the last quarter of the 19 th century.

There is also archaeological value in the building and site, since it is capable of revealing information about past human activity, both pre- and post-1881. This may go as far back as a timber wharf that extended into the harbour from somewhere near the middle of the Lambton Quay boundary of the land, to the remains of temporary buildings behind the Supreme Court, to pit toilets, to the three major public buildings that used to occupy parts of the land.

Note that cultural values to tangata whenua has not been assessed as part of this statement.

\subsection{Heritage Inventory}

Taking account of the preceding summary of cultural heritage values, the spaces and fabric of the Supreme Court building have been analysed, and a hierarchy of values has been established.

The meaning of the assigned values are as follows:

Cultural Heritage Value 1

This means the element or space is of exceptional cultural significance value. 


\section{Cultural Heritage Value 2}

This means the element or space is of considerable cultural significance.

Cultural Heritage Value 3

This means the element or space is of some cultural significance.

\section{No Cultural Heritage Value}

Elements or spaces of little or no cultural significance are not included in the inventory. All fabric not otherwise identified falls into this category.

Each of the elements and spaces of the building have been described below. The spaces are coded according to the Warren and Mahoney drawings of the existing plan layouts, with their heritage significance rating, description, and fabric of significance.

Mention has not been made of the general fabric of the spaces, in particular the solid plasterwork or timber flooring; however wherever such fabric is original or early, it should be regarded as integral to the heritage significance of the space.

The spaces are described in numerical order, which is not necessarily a sequential order through the building. (The space codings derive from earlier drawings, and where numbers are missing, this is because walls or partitions have been removed, eliminating a space.) Note that special doors are identified according to the space in which they are first encountered, rather than with the room they open into. 
$\varnothing$

3

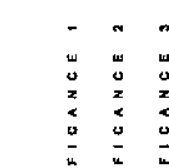

D

D

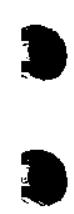

2
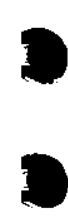

?

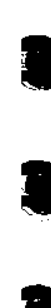

2

$?$

$?$
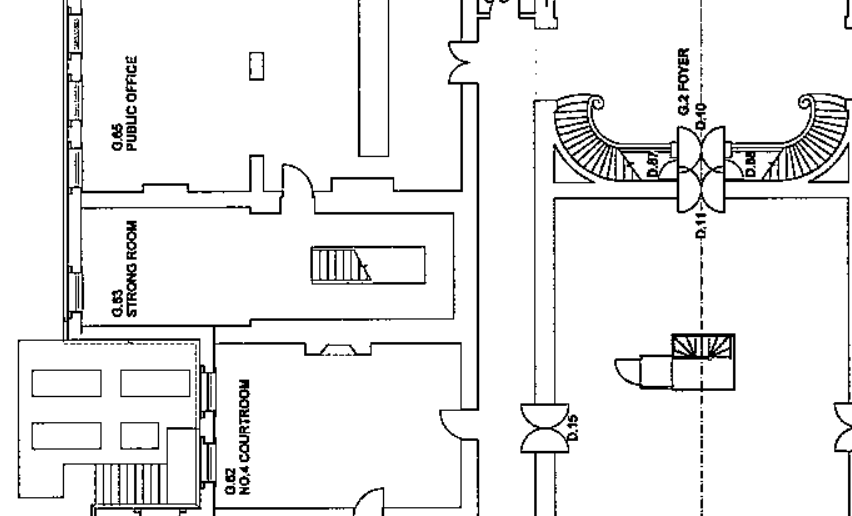

度

密

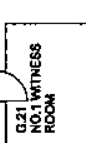

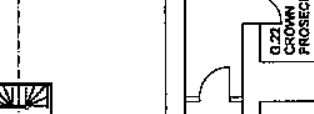

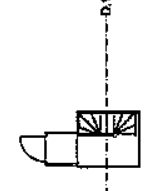

3

圈

H

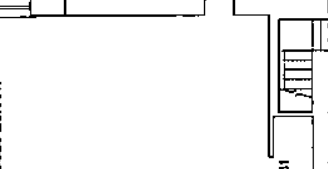

,
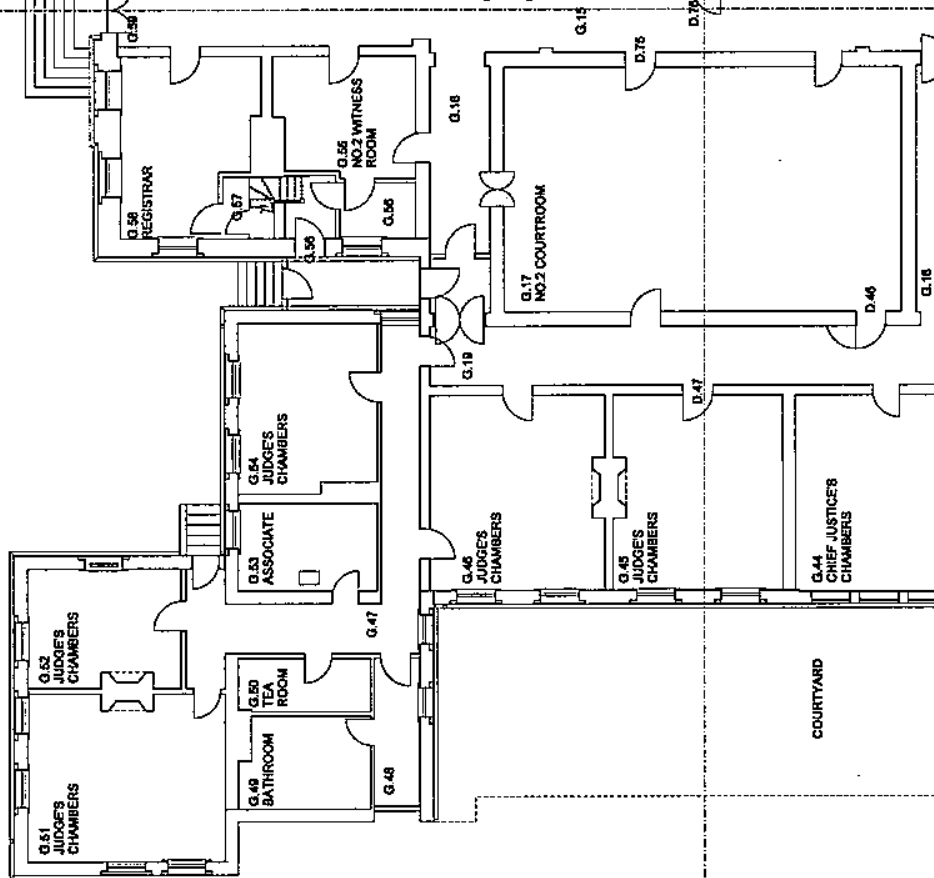

$\frac{1}{2}$ 

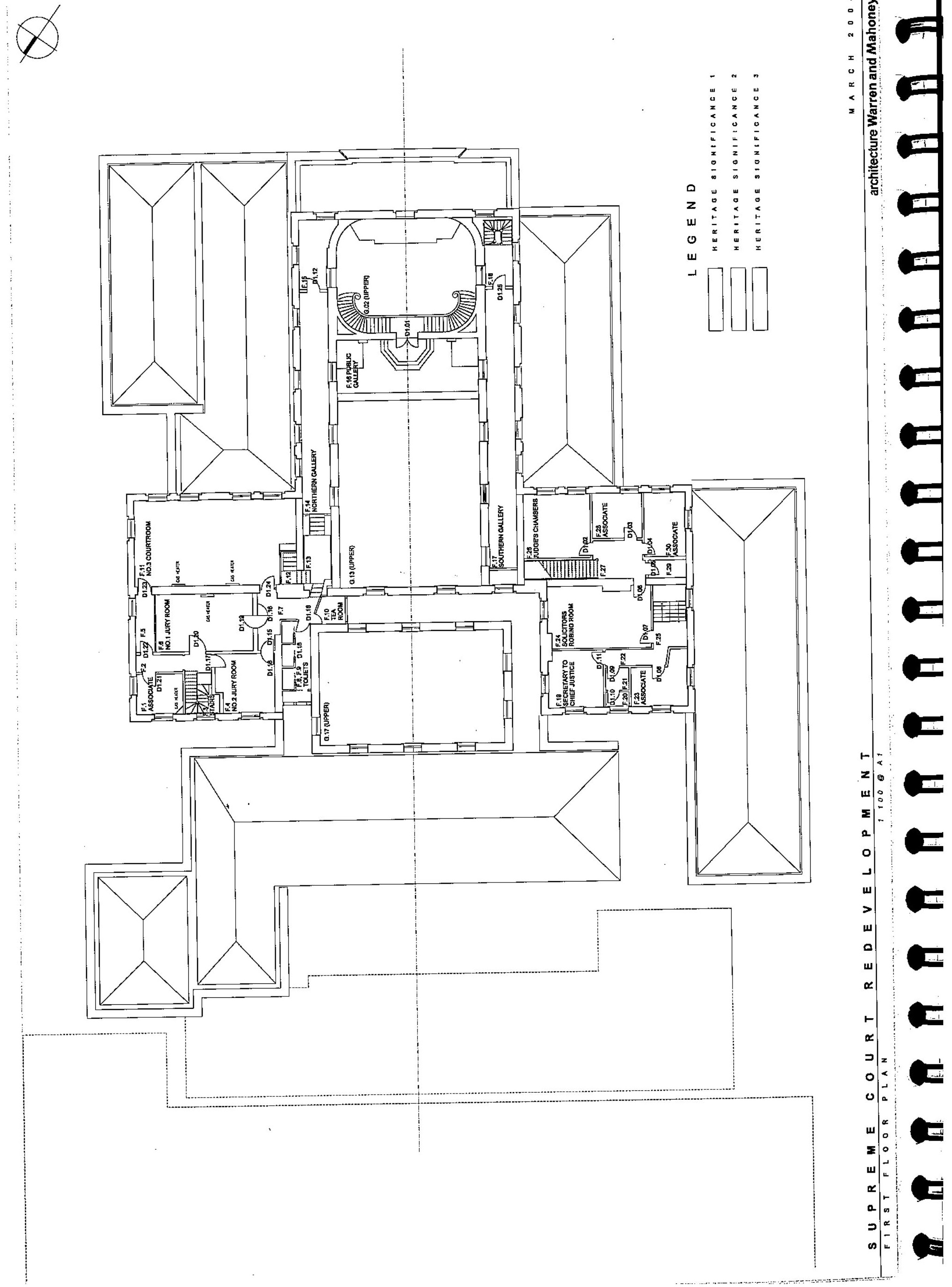
1

1

7

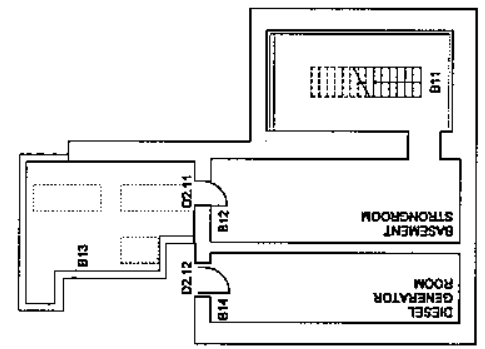

10

(17)

(19)

(1)

(1)

(3)

(2)

0

0

0

8

0

0
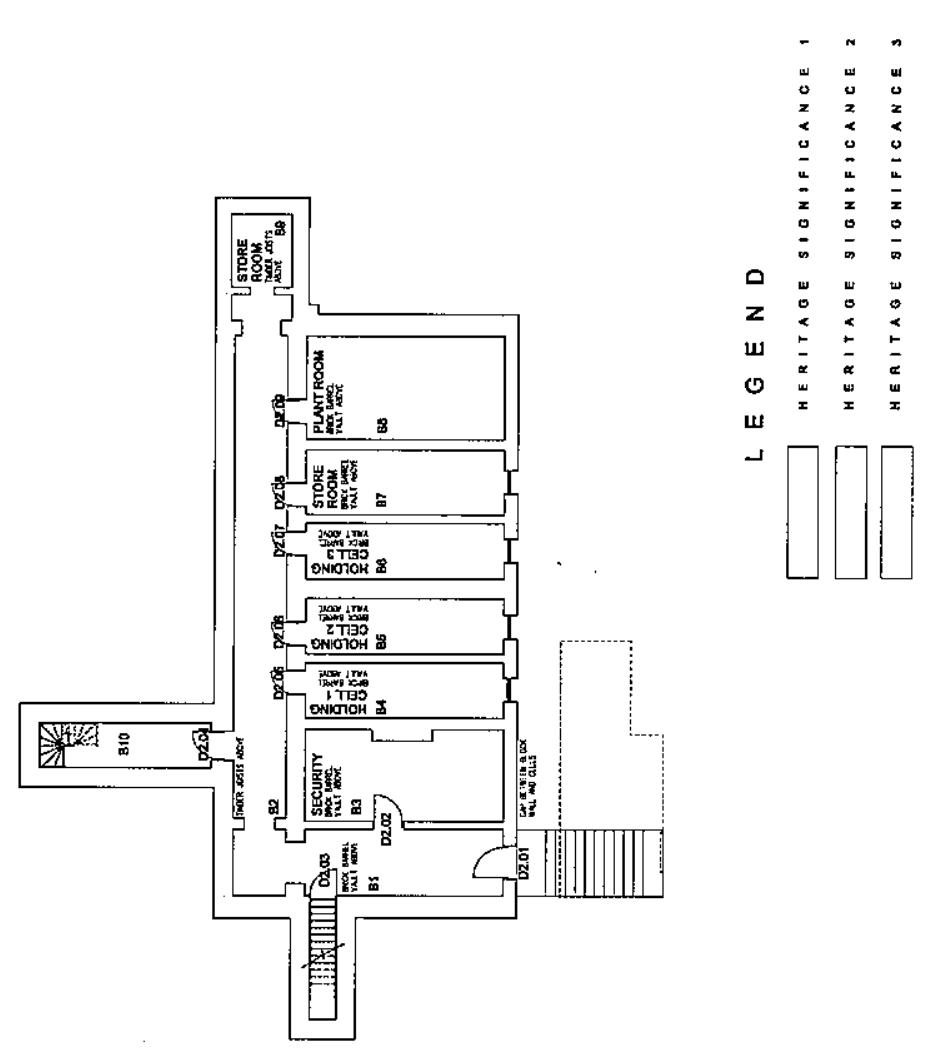


\subsection{Conservation Policy}

The following policy sets out different levels of intervention that are appropriate for the different levels of cultural heritage value within the building as defined in the previous section.

The intention is that changes to the building, which are necessary to meet new functional requirements and to comply with code requirements, should be confined as far as possible to areas of low value. The spaces of high value should be restored where this is appropriate but otherwise should be modified as little as possible so as to maintain and enhance the heritage value of the building.

Appropriate conservation processes for the various assigned values are as follows:

Cultural Heritage Value 1

This means the element or space is of exceptional cultural heritage value. Modification should be allowed for the purpose of meeting essential functional requirements, safeguarding the building, or meeting statutory requirements. Any such modification should be carried out only if no other reasonable option is available; it should be as discreet as possible and the minimum necessary.

Allowable processes of change include maintenance, stabilisation, repair, restoration and adaptation.

Cultural Heritage Value 2

This means the element or space is of considerable cultural heritage value. Modification should be allowed for the purpose of meeting functional requirements, safeguarding the building, or meeting statutory requirements. Any such modification should be as discreet as possible and the minimum necessary.

Allowable processes of change include maintenance, stabilisation, repair, restoration and adaptation.

Cultural Heritage Value 3

This means the element or space is of some cultural heritage value. Adaptation, or removal and reuse may be allowed for the reasons given above and to effect any functional improvement.

Allowable processes of change include maintenance, stabilisation, repair, restoration and adaptation.

No Cultural Heritage Value

Elements or spaces of little or no cultural significance. All fabric not otherwise identified falls into this category. The adaptation, removal and/or reuse of this fabric may be carried out to effect any improvement.

Allowable processes of change include maintenance, stabilisation, repair, restoration and adaptation. Removal and/or reuse of fabric is allowable.

For all categories, proper recording of the fabric before modification should be carried out. All relevant requirements of the ICOMOS New Zealand Charter for the Conservation of Places of Cultural HeritageValue should be followed. For the purposes of this report, the following definitions from the New Zealand Charter are relevant. 
Conservation means the process of looking after a place so as to safeguard its cultural heritage value.

Maintenance means the protective care of a place.

Repair means making good decayed or damaged fabric.

Restoration means returning a place as nearly as possible to a known earlier state.

Stabilisation means the arrest of the processes of decay.

Adaptation (or alteration) means modifying a place to suit it to a compatible use, involving the least possible loss of cultural heritage value.

The full text of the Charter is included in Appendix III.

\subsection{Notes on Conservation Actions}

Without being definitive, the following notes outline some general conservation actions that flow from the preceding analysis of heritage values and conservation policies.

\section{Chimneys}

Re-instatement of the chimneys above the roof line of the building is not judged to be an important conservation issue. While the original chimneys have a picturesque silhouette, and add visual interest to the building, they were always functional elements, not strictly part of the formal architectural composition. They would have no functional use today.

There is however, the possibility that modern heating/servicing of the building will require openings through the roof, and that chimney-like ventilating structures will be needed. In this case, re-instatement of the chimneys, with such a functional use, would be considered.

\section{Fireplaces}

Despite the lack of any functional need for fureplaces, the repair and re-instatement of fireplaces and fire surrounds is considered important in spaces of heritage significance 1 and 2, since these are an integral part of the architecture and finishing detail of the spaces of which they are a part.

\section{Joinery}

Protection of joinery during the construction process is an extremely important matter. While some joinery elements must be removed because it is impractical to protect them (doors and skirting boards for example), other elements (such as panelling) might be at greater risk of damage in the removal, storage, and re-instatement process. Careful consideration will be given to balancing these risks.

Wherever joinery is removed, it will be labelled, safely stored and restored to its original location.

Careful repair will always be favoured over replacement. 


\section{New Openings}

A new opening in the exterior shell of the building (on the west elevation, first floor, where the new glass link is to be built), will be made by cutting down the sill of the existing window opening. This will leave intact the jambs, head and pediment of the existing window opening, minimising loss of fabric.

\section{No 3 Court}

This space was re-fitted completely in the $1960 \mathrm{~s}$, and is a relatively authentic courtroom from this period. Consideration will be given to retaining this space in its present form (subject to change for functional reasons) as a vivid illustration of the long process of change that the building has undergone over its 125 year history.

\section{Colours and Finishes}

Colours should follow the historical precedent of the original colours, especially in spaces of heritage significance 1 . Research will involve a detailed analysis of original colours and finishes, and these should be used again except where they conflict with the modern functional requirements of the space.

If special finishes are uncovered (such as marbling or stencilling), a professional materials conservator will be consulted about the treatment and/or reproduction of these finishes.

\section{Flooring}

Consideration will be given to the reinstatement of tongue and groove timber flooring in some spaces, especially in spaces of heritage significance 1 or 2, and where this is shown to have been the original finish. (An example may be corridors where there may originally have been a carpet runner with exposed floorboards on either side).

Flooring will need to be lifted for structural work to be carried out, but will be done carefully so that boards in good condition can be re-used.

\section{Sub-floor}

Sub-floor timbers that are in good condition and which are heart native, will be carefully removed for possible re-use (in machined down form) for joinery items or finishing work as may be required in the building.

\section{Base Isolation}

It is acknowledged that there will be visible evidence of the base isolation of the building, at the line of separation between the foundations and the super-structure. This is to be carefully detailed and will be accepted as a legitimate and necessary alteration to the fundamental structure of the building, desirable for the long-term protection of both the building and its occupants. 
Appendix IV

Supreme Court Complex - Architectural Drawings

Please note: Some drawings have been omitted from this set for security reasons. 


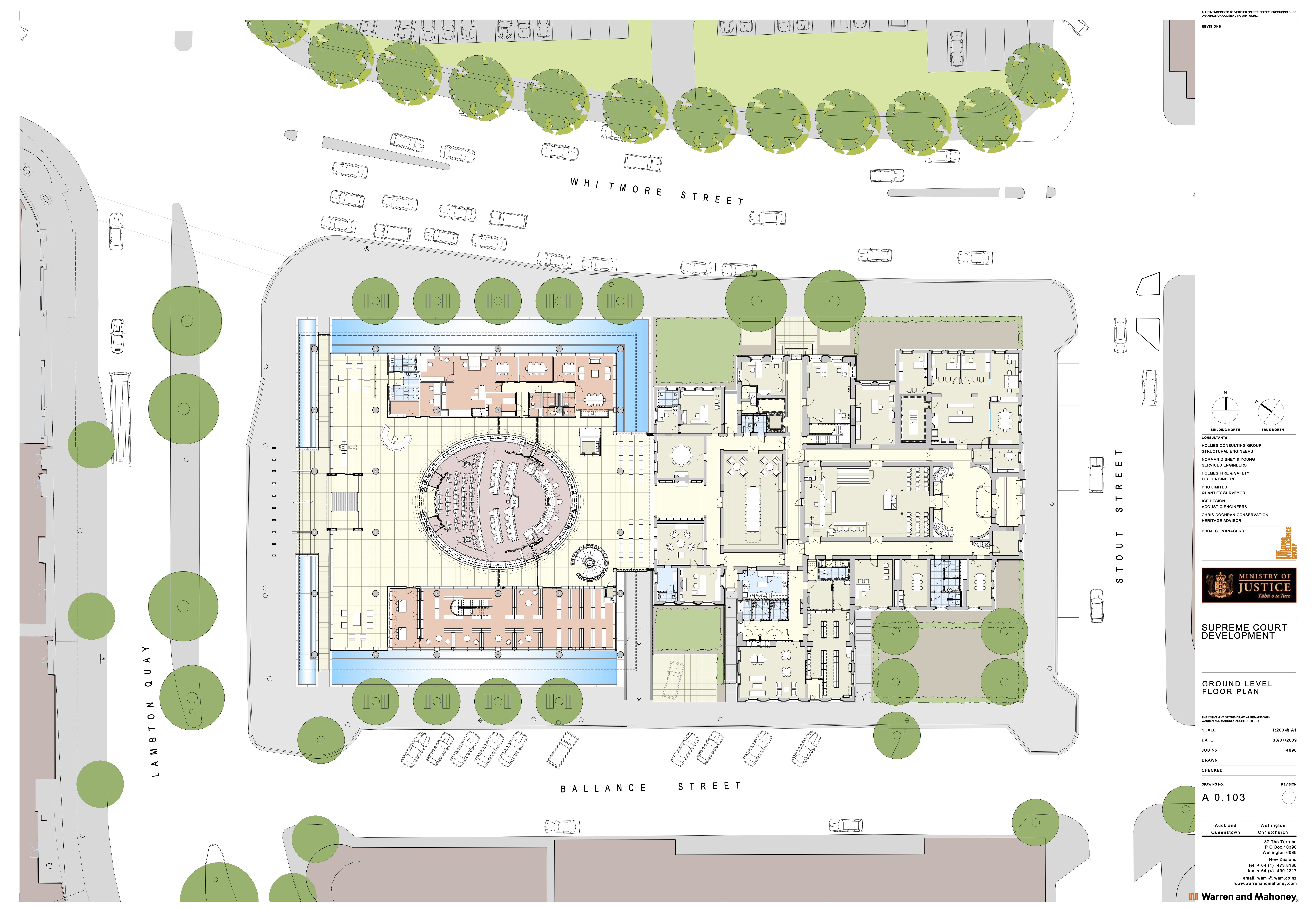



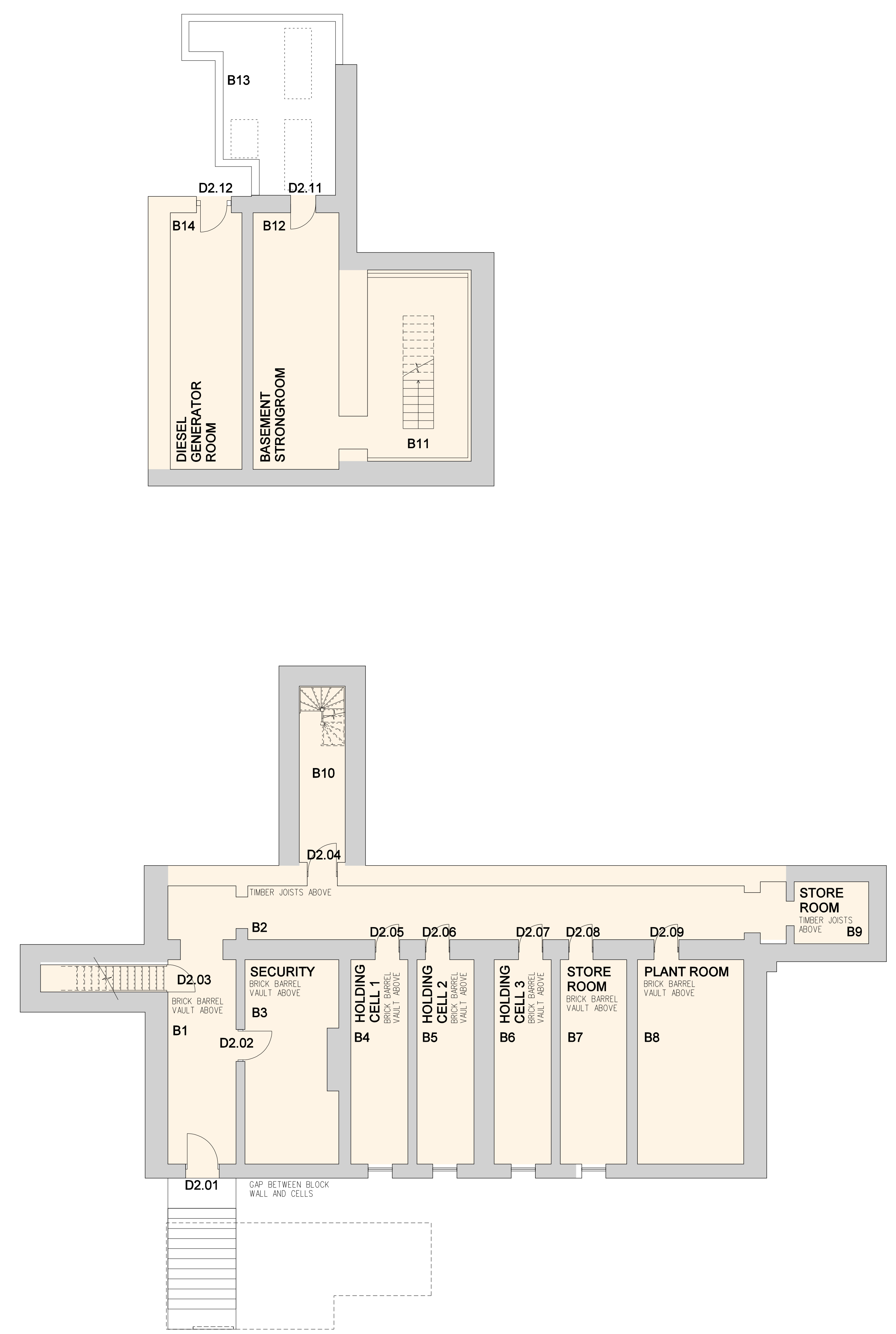







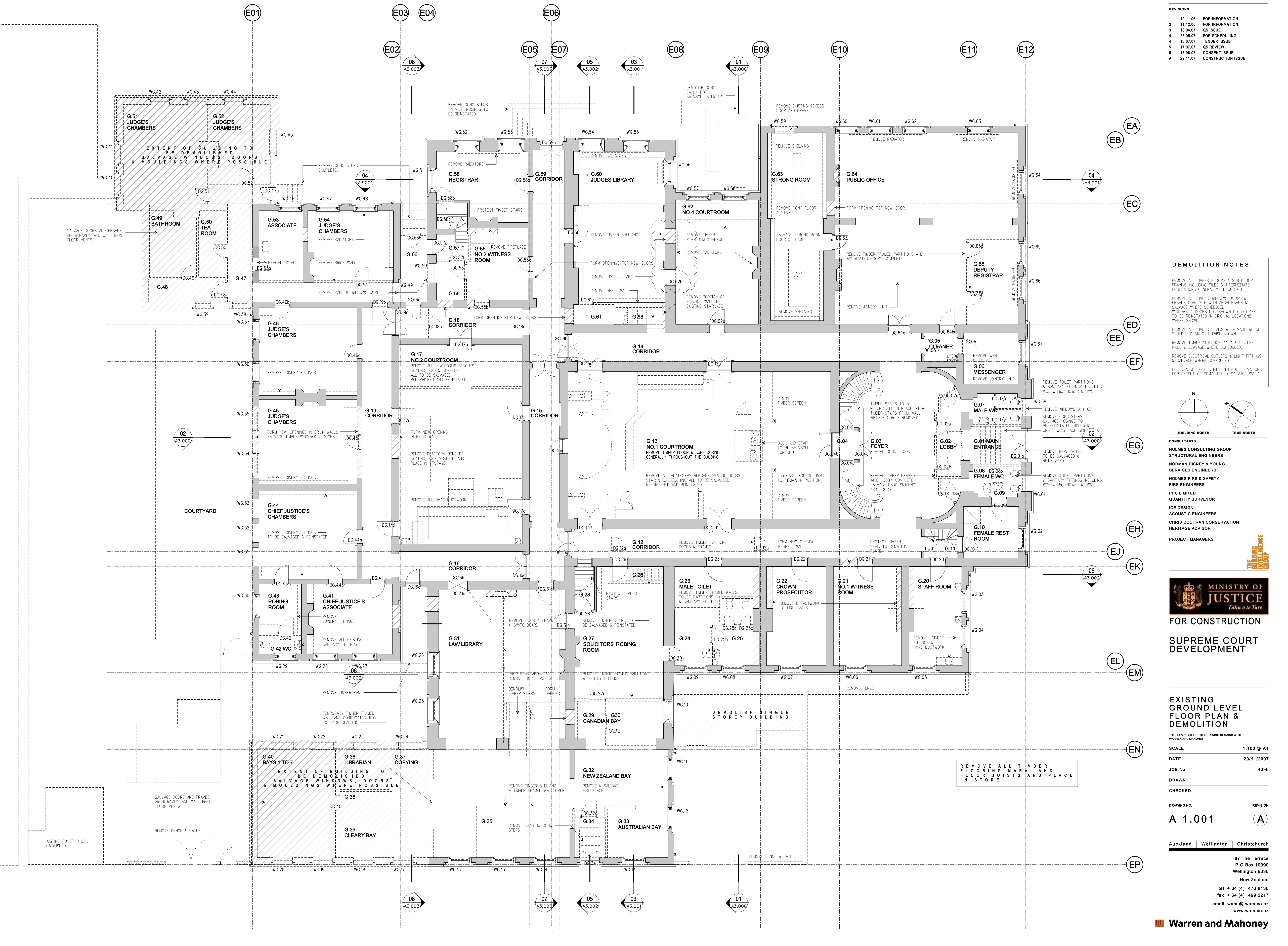









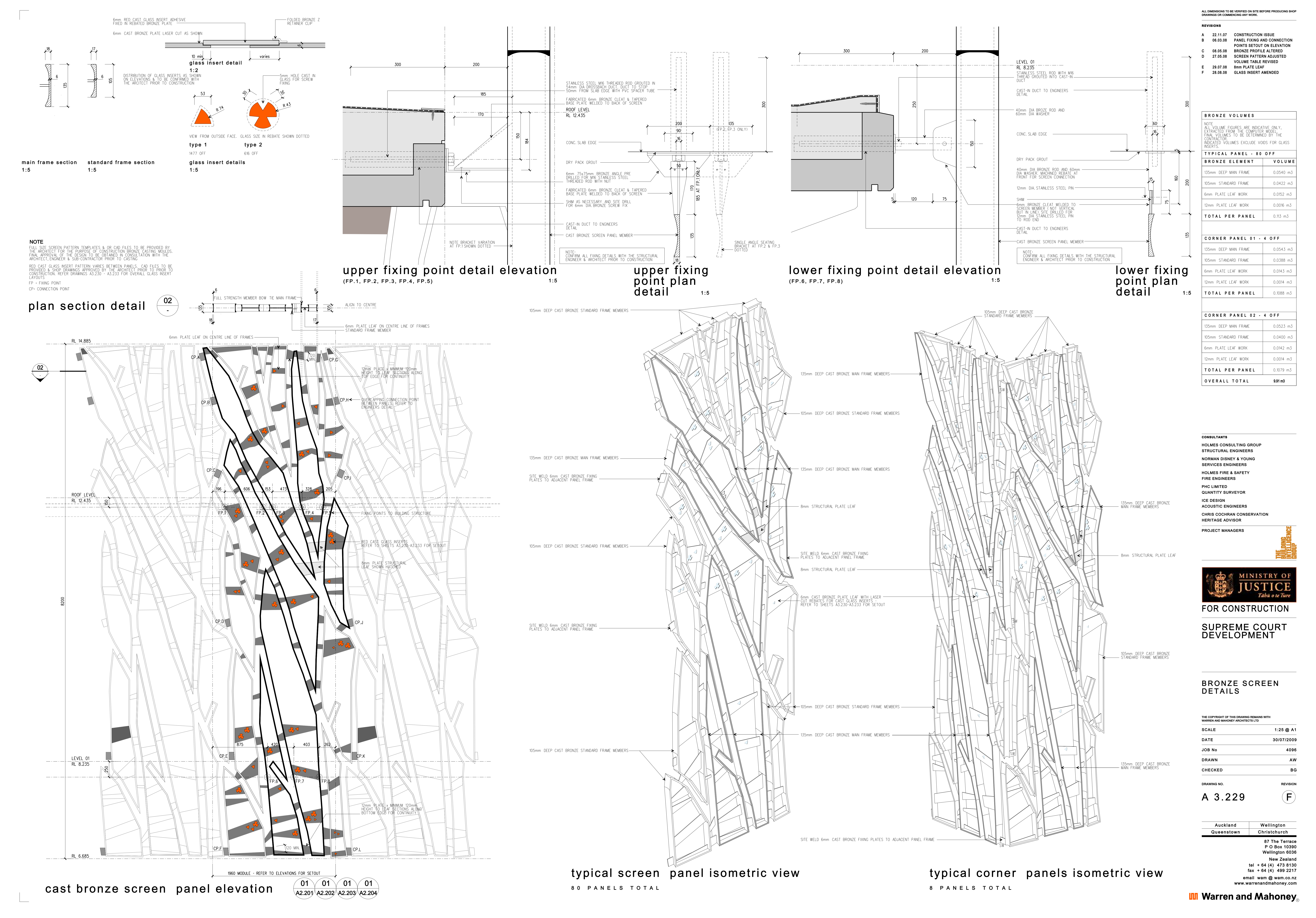





(a)

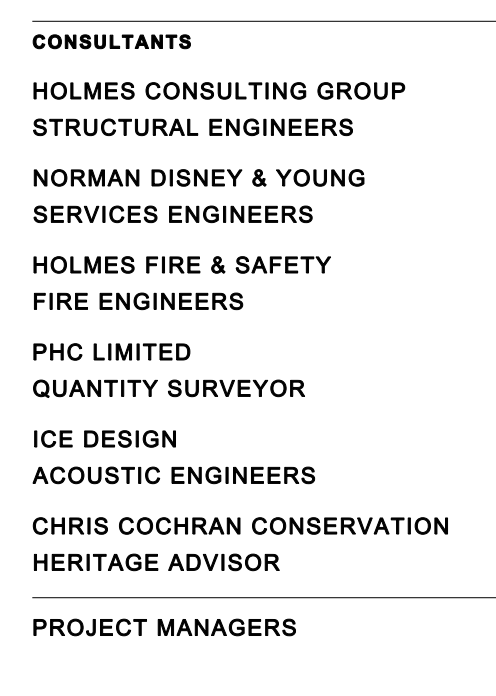

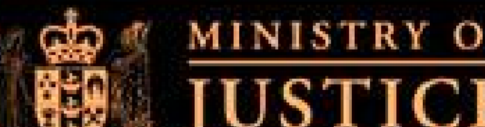

FOR CONSTRUCTION SUPREME COOURT
DEVELOPMENT

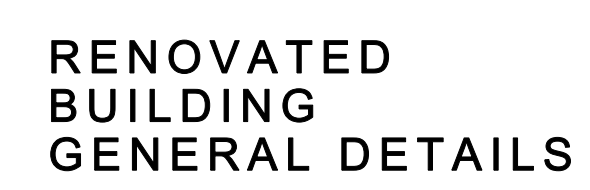

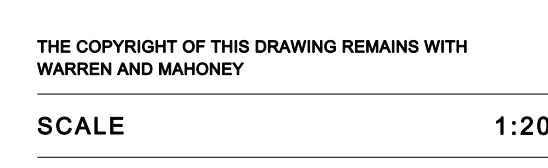

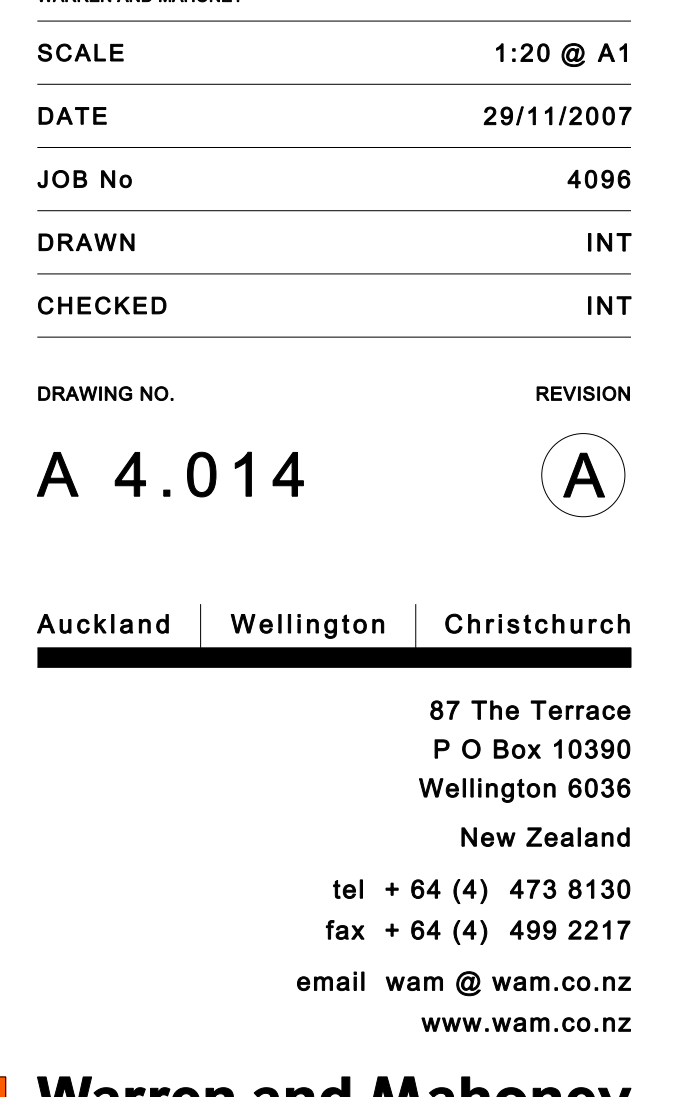

IIII Warren and Mahoney 


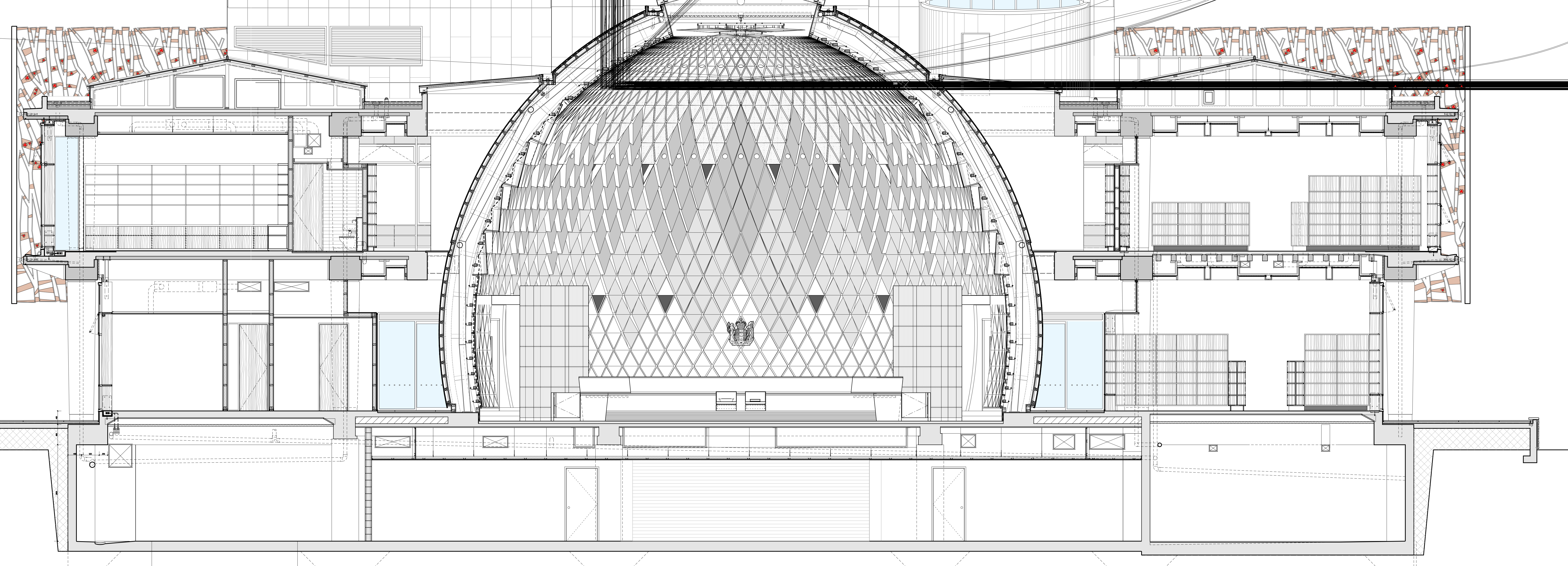









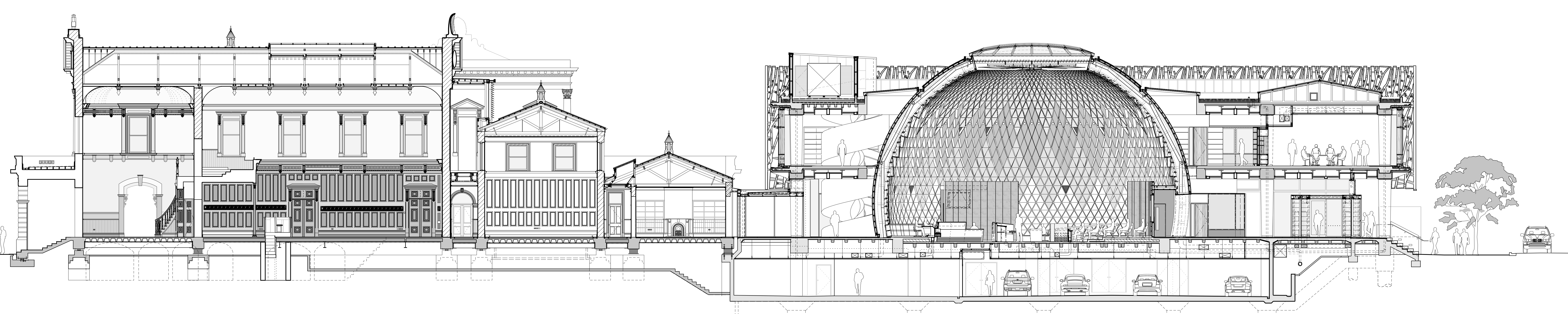









\section{Appendix IV}

\section{Supreme Court Complex - Selected Credits and Awards}

\section{Client}

The Ministry of Justice

\section{Location}

Wellington, New Zealand

\section{Completed}

2010

\section{Architects}

Old High Court Building - Pierre Finch Martineau Burrows (1880); John Campbell (alterations); Warren and Mahoney (2010)

Supreme Court - Warren and Mahoney

\section{Professional Services}

Acoustics Consultant

Ice Design Australia Pty Ltd

Consultant Artist

Neil Dawson

Cost Consultant

$\mathrm{PHC}$

Environmental Engineer

Norman Disney \& Young

Heritage Architect Consultant

Chris Cochran Conservation Architect

Interior Designer

Warren and Mahoney

Landscape Architect

\section{Suppliers and Products}

Bronze Screen

A\&G Price Ltd

Courtroom Beech Timber

Lindsay \& Dixon Ltd

Curved Toughened Glass

Metro Glasstech

Elevators

Kone Elevators

Joinery

Ferndale Furniture

Plasterwork

Sto European Plaster Systems

Structural Steel 
Boffa Miskell

Lighting Consultant

Norman Disney \& Young

Main Contractor

Mainzeal Construction

Mechanical Services

Norman Disney \& Young

Project Manager

The Building Intelligence Group

Structural Engineer

Holmes Consulting Group
Croucher \& Crowder Engineering

Timber panelling

Jones \& Sandford Joinery Ltd

Windows and doors

Thermosash

Zinc Roofing and Copper Cladding

VM Zinc

\section{Awards}

2011

- NZIA Architecture Award - Heritage

- Property Council of New Zealand - Heritage and Adaptive Reuses, Excellence

- NZIA Architecture Award - Interior Architecture

- Property Council of New Zealand - Special Purpose, Excellence

2010

- NZIA Colour Award

- NZIA Local Award - Interior Architecture

- NZIA Local Award - Heritage

- NZ Wood Timber Award - Interior Design

- Registered Master Builders Wellington - Commercial Project of the Year

- Registered Master Builders - Industrial and Infrastructure - National Gold Award, Commercial Project of the Year

- World Architecture Festival Barcelona - Civic \& Community, Shortlisted

- Institution of Structural Engineers (IStructE) Award - Heritage, Building/Infrastructure

- DINZ Best Design Award - Built Environment, Gold

- Greater Wellington Regional Council - Historic Heritage Award 


\section{Bibliography}

\section{Books, Articles, Reports}

Allison, Clare. "High Court sits for last time in old building." The Timaru Herald (8 April 2009). http://www.stuff.co.nz/timaru-herald/news/2322073/High-Court-sits-forlast-time-in-old-building

Anderson, Benedict. Imagined Communities. Reflections on the Origin and Spread of Nationalism. Rev. ed. London: Verso, 2006.

Annable, Rosemary. A Setting for Justice: Building for the Supreme Court of New South W ales. Sydney: University of New South Wales Press, 2007.

Arnheim, Rudolf. The Dynamics of Architectural Form. Berkeley: University of California Press, 1977.

Austin, Mike. "Polynesian Influences in New Zealand Architecture." In Leach, Andrew, Antony Moulis and Nicole Sully (eds.). Shifting Views: Selected Essays on the Architectural History of Australia and New Zealand. St Lucia, Qld.: University of Queensland Press, 2008, 123-131.

Baragwanath, William D. "What is distinctive about New Zealand law and the New Zealand way of doing law? New Zealand law and Māori." Address to the New Zealand Law Commission's $25^{\text {th }}$ Anniversary Seminar. Wellington, New Zealand, 25 August 2006.

Barnstone, Deborah A. The Transparent State. Architecture and Politics in Postwar Germany. New York: Routledge, 2005. 
Beattie, D. S., I. H. Kawharu, R. M. King, \& J. H. Murray. Report of Royal Commission on the Courts. AJHR, H.2.. Wellington: Government Printer, New Zealand: 1978.

Bell, Claudia. Inventing New Zealand: Everyday Myths of Pakeha Identity. Auckland: Penguin Books, 1996.

Bell, Claudia, \& John Lyall. The Accelerated Sublime: Landscape, Tourism and Identity. Westport, Conn.: Praeger, 2001.

Bell, Claudia, \& Steve Matthewman (eds.). Cultural Studies in Aotearoa New Zealand. Identity, Space and Place. Auckland: Oxford University Press.

Braithwaite, John. Crime, Shame and Reintegration. New York: Cambridge University Press, 1989.

Burrows, John F. Statute Law in New Zealand. $3^{\text {rd }}$ ed. Wellington: LexisNexis, 2003.

Cabinet Office. Cabinet Manual 2008. Wellington: Government Printer, 2008.

http://www.cabinetmanual.cabinetoffice.govt.nz/

Christchurch Art Gallery. Public Art in Central Christchurch. A Study by the Robert McDougall Art Gallery. Christchurch, New Zealand: 1997. http://christchurchartgallery.org.nz/media/uploads/2010 07/PublicArt-ChCh1997.pdf

Clark, Helen. “Te Ariki Dame Te Atairangikaahu.” Wellington, New Zealand: 2006. http://www.beehive.govt.nz/node/26785 
Clark, Justine, \& Paul Walker. Looking for the Local: Architecture and the New Zealand Modern. Wellington: Victoria University Press, 2000.

Cochran, Chris. Supreme Court. 42 Stout Street. Conservation Report for The Ministry of Justice. Wellington, New Zealand, 2006.

Cooke, Robin. "Introduction” (1990) 14 New Zealand Universities Law Review 1.

—. “The New Zealand Legal Identity” (1987) 3 Canterbury Law Review 171.

Dalow, Chris. "New Zealand Law Society President's Address on the Ceremonial Sitting of the Supreme Court” (1 July 2004). Wellington, New Zealand. http://www.courtsofnz.govt.nz/from/speeches-and-papers/\#speechpaper-list-firstsitting

Dovey, Kim. Framing Places: Mediating Power in Built Form. New York: Routledge, 2008.

Edelman, Murray. The Symbolic Uses of Politics. Urbana: University of Illinois Press, 1964.

Elias, Sian. "Speech at the Special Sitting of the New Zealand Supreme Court" (1 July 2004). Wellington, New Zealand. http://www.courtsofnz.govt.nz/from/speeches-andpapers/\#speechpaper-list-first-sitting

-. "Speech of the Chief Justice of New Zealand at the Opening of the Supreme Court of New Zealand” (18 January 2010). Wellington, New Zealand. http://www.courtsofnz.govt.nz/from/speeches-and-papers/\#speechpaper-list-2010

Flanders, Steven (ed.). Celebrating the Courthouse. A Guide for Architects, their Clients, and the Public. New York: W. W. Norton, 2006. 
Fort, William S. "Facilities for the Administration of Justice.” In Winters, Glenn R. (ed.) Courthouses and Courtrooms: Selected Readings. Chicago: American Judicature Society, 1972, 4-8.

Foucault, Michel. Discipline and Punish: the Birth of the Prison. New York: Pantheon, 1977.

Fowler, Michael. Buildings of New Zealanders. Auckland: Lansdowne Press, 1984.

Garapon, Antoine. Bien juger: Essai sur le rituel judiciaire. Paris: Editions Odile Jacob, 1997.

Gatley, Julia (ed.). Long Live the Modern: New Zealand's New Architecture 1904 - 1984.

Auckland: Auckland University Press, 2008.

Gentner, Dedre, Keith J. Holyoak, \& Boicho N. Kokinov (eds.). The Analogical Mind Cambridge: MIT Press, 2001.

Goodsell, Charles. T. The Social Meaning of Civic Space: Studying Political Authority Through Architecture. Lawrence: University Press of Kansas, 1988.

Griebel, Michael, \& Todd S. Phillips. “Architectural Design for Security in Courthouse Facilities." Annals of the American Academy of Political and Social Science Vol. 576 Courthouse Violence: Protecting the Judicial Workplace (July 2001) 118-131.

Groat, Linda, \& David Wang. Architectural Research Methods. New York: Wiley, 2002.

Gusfield, Joseph R. Symbolic Crusade: Status Politics and the American Temperance Movement. Urbana: University of Illinois Press, 1966. 
Haldar, Piyel. "In and Out of Court: Topographies of Law and the Architecture of Court Buildings (A Study of the Supreme Court of Israel)" International Journal for the Semiotics of Law Vol. VII, no. 20 (1994) 185-200.

Hammer, Louis. "Architecture and the Poetry of Space." Journal of Aesthetics and Art Criticism. 39 (Summer 1981): 381-88.

Harvey, Nicola. “Art World.” Mindfood (Apr 2010) 61.

Hayward, Janine A. D. "In Search of a Treaty Partner : Who, or What, is the Crown?" Ph.D. diss., Victoria University of Wellington, New Zealand, 1995. http://hdl.handle.net/10063/744

Hazard, John N. "Furniture Arrangement as a Symbol of Judicial Roles." ETC: A Review of General Semantics 19 (July 1962): 181-88.

Hodgson, Terence. Looking at the Architecture of New Zealand. Wellington: Grantham House, 1990.

Howard, Peter. Heritage: Management, Interpretation, Identity. London: Continuum, 2003.

Jencks, Charles. The Language of Post-Modern Architecture. New York: Rizzoli, 1977.

Jones, Paul. "Architecturing Modern Nations: Architecture and the State." In Gerard Delanty and Engin F. Isin (eds.). Handbook of Historical Sociology. London: Sage, 2003, $301-311$

-. The Sociology of Architecture. Constructing Identities. Liverpool: Liverpool University Press, 2011. 
Jutel, Thierry. "Lord of the Rings: Landscape, Transformation, and the Geography of the Virtual." In Bell, Claudia, and Steve Matthewman (eds.). Cultural Studies in Aotearoa New Zealand. Identity, Space and Place. Auckland: Oxford University Press, 54-65.

Keith, Kenneth. "On the Constitution of New Zealand: An Introduction to the Foundations of the Current Form of Government." In Cabinet Office. Cabinet Manual 2008 Wellington: Government Printer, 2008. http://www.cabinetmanual.cabinetoffice.govt.nz/

King, Michael. The Penguin History of New Zealand. Wellington: Penguin, 2003.

Kristal, Marc. Immaterial World: Transparency in Architecture. New York: Monacelli Press, 2011.

Lasswell, Harold D., in collaboration with Merritt B. Fox. The Signature of Power: Buildings, Communication, and Policy. New Brunswick, N.J.: Transaction Books, 1979.

Law Reform Commission of Western Australia. Review of the Criminal and Civil Justice System in Western Australia (Project 92 - Consultation Papers). Perth: Government Printer, June 1999. http://www.lrc.justice.wa.gov.au/092g.html

-. Review of the Criminal and Civil Justice System in Western Australia (Project 92 - Final Report) Perth: Government Printer, September 1999. http://www.lrc.justice.wa.gov.au/092g.html

Maass, Anne, Ilaria Merici, Erica Villafranca, Rosaria Furlani, Elena Gaburro, Anna Getrevi \& Margherita Masserini. "Intimidating Buildings: Can Courthouse Architecture Affect Perceived Likelihood of Conviction?” Environmental Behavior 2000 32: 674. doi: $10.1177 / 00139160021972739$ 
Martin, Lewis E. Built for Us. The Work of Government and Colonial Architects, 1860s to 1960s. Dunedin: University of Otago Press, 2004.

Masson, Antoine, \& Kevin O’Connor (eds.). Representations of Justice. Brussels: P.I.E. Peter Lang, 2007.

McNamara, Martha J. From Tavern to Courthouse: Architecture \& Ritual in American Law, 16581860. Baltimore: John Hopkins University Press, 2004.

Milne, David. "Architecture, Politics and the Public Realm." Canadian Journal of Political and Social Theory 5 (Winter/Spring 1981): 131-146.

Ministry of Justice. The Design of the New Building. Wellington, Government Printer: n.d.. http://www.courtsofnz.govt.nz/about/supreme/the-supreme-court-complex/thedesign-of-the-new-building

Mitchell, David, and Gillian Chapman. The Elegant Shed: New Zealand Architecture Since 1945. Auckland: Oxford University Press, 1984.

Mulcahy, Linda. "Architects of Justice: the Politics of Courtroom Design.” Social \& Legal Studies 2007 16: 383. doi: 10.1177/0964663907079765.

New Zealand Law Commission. The Structure of the Courts. NZLC R7, AJHR E.31D (Wellington: Government Printer, 1989).

Norberg-Schultz, Christian. "Place." $A A Q$ 8(4) (1976): 3-10.

—. Genius Loci: Towards a Phenomenology of Architecture. New York: Rizzoli, 1979.

—. Space and Architecture. New York: Praeger, 1971. 
Noonan, Rosslyn J. By Design: A Brief History of the Public Works Department, Ministry of Works 1870 - 1970. Wellington: Government Printer, 1975.

Office of the Attorney-General. Discussion Paper: Reshaping New Zealand's Appeal Structure. Wellington: Government Printer, 2000.

-. Report of the Advisory Group. Replacing the Privy Council: A New Supreme Court. Wellington: Government Printer, 2002.

Office of the Solicitor-General. Appeals to the Privy Council: Report of the Solicitor-General to the Cabinet Strategy Committee on Issues of Termination and Court Structure. Wellington: Government Printer, 1995.

Orange, Claudia. The Treaty of Waitangi. $2^{\text {nd }}$ ed. Wellington: Bridget Williams Books, 2011.

Orbell, Margaret. The Concise Encyclopedia of Mäori Myth and Legend. Christchurch: Canterbury University Press, 1998.

Orwin, Joanna. Kauri: Witness to a Nation's History. Auckland: New Holland, 2004.

Paama-Pengelly, Julie. Māori Art and Design: Weaving, Painting, Carving and Architecture. Auckland: New Holland, 2010.

Palmer, Matthew. S. R. The Treaty of Waitangi in New Zealand's Law and Constitution. Wellington: Victoria University Press, 2008.

Park, Geoff. Nga Uruora - The Groves of Life. Ecology and History in a New Zealand Landscape. Wellington: Victoria University Press, 1995. 
Pati, Debajyot, Mallika Bose, \& Craig Zimring. "Rethinking Openness: Courthouses in the United States." Journal of Architectural and Planning Research 24:4 (Winter, 2007) 308324.

Perry, Barbara A. "The Israeli and United States Supreme Courts: A Comparative Reflection on their Symbols, Images and Functions." The Review of Politics 63(2) (Spring 2001), 317-339.

Redstone, Louis G. Institutional Buildings. Architecture of the Controlled Environment. New York: McGraw-Hill, 1980.

Resnik, Judith, \& Dennis E. Curtis. 'From 'Rites' to 'Rights' of Audience: The Utilities and Contingencies of the Public's Role in Court-Based Processes.” In Antoine Masson \& Kevin O’Connor (eds.). Representations of Justice. Brussels: P.I.E. Peter Lang, 2007, $195-236$.

—. "Representing Justice: From Renaissance Iconography to Twenty-First-Century Courthouses." Proceedings of the American Philosophical Society (2007) 151(2): 139-183.

Richardson, Peter. "Building the Dominion: Government Architecture in New Zealand, 1840 - 1922.” Ph.D. diss., University of Canterbury, New Zealand, 1997.

Scott, Anthony. A History of the Oamaru Courthouse. Wellington: Government Printer, 1983.

Simpson, Philip. G. Pōhutukawa and Rātā : New Zealand's Iron-hearted Trees. Wellington: Te Papa Press, 2005.

Smeets, René. Signs, Symbols and Ornaments. New York: Van Nostrand Reinhold, 1973. 
Smith, Paul F. “Architecture, Symbolism and Surrealism.” Architectural Design 48 (2) (1978): 150-151.

Spiller, Peter, Jeremy Finn, \& Richard Boast. A New Zealand Legal History. $2^{\text {nd }}$ ed. Wellington: Brooker's, 2001.

Stacpoole, John. Colonial Architecture in New Zealand. Wellington: Reed, 1976.

Stacpoole, John, and Peter Beaven. Architecture 1820 - 1970. Wellington: Reed, 1972.

Tamanaha, Brian Z. A Concise Guide to the Rule of Law. St.John's University School of Law Legal Studies Paper \#07-0082. New York: St John’s University, 2007. http://ssrn.com/abstract $=1012051$

Taylor, Katherine. In the Theatre of Criminal Justice. Princeton, NJ: Princeton University Press, 1993.

Te Heuheu, Georgina. "Mauri Stone Laid at New Supreme Court” (3 March 2009). Wellington, New Zealand. http://www.beehive.govt.nz/release/mauri-stone-laidnew-supreme-court

Te Puni Kokiri \& Ministry of Justice. Te Whanaungatanga a te Karauna me te Māori: Ngä tohutobu mo te kawanatanga me ngà tari kawanatanga/Crown-Māori Relationship Instruments: Guidelines and Advice for Government and State Sector Agencies (Wellington: Government Printer, 2006). http://www.justice.govt.nz/publications/global-publications/c/crownmaori-relationship-instruments-guidelines-and-advice-for-government-and-statesector-agencies-december-2006) 
Trapeznik, Alexander (ed.). Common Ground? Heritage and Public Places in New Zealand. Dunedin: University of Otago Press, 2000.

Trapeznik, Alexander \& Gavin McLean. "Public history, heritage and place." In Alexander Trapeznik (ed.). Common Ground? Heritage and Public Places in New Zealand. Dunedin: University of Otago Press, 2000, 13-24.

Vale, Lawrence J. Architecture, Power, and National Identity. $2^{\text {nd }}$ ed. London: Routledge, 2008.

Waitangi Tribunal. Ngai Tahu Report (Wai 27). Wellington: Government Printer, 1991.

-. Report of the Waitangi Tribunal on the Manukan Claim (Wai 8). $2^{\text {nd }}$ ed. Wellington: Government Printer, 1989.

-. Report of the Waitangi Tribunal on the Orakei Claim (Wai 9). Wellington: Government Printer, 1987.

Warren, Marilyn. “The Politics of Court Architecture.” Paper presented at the Third Justice Environments Conference, University of Western Sydney, Sydney, Australia, May 2010. http://www.uws.edu.au/ data/assets/pdf file/0010/138295/The Politics of Co urt Architecture.pdf

Wellington City Council. Council Decision - Notice of Requirement: Supreme Court of New Zealand. Wellington, New Zealand: 12 April 2007.

—. Wellington City District Plan. Wellington, New Zealand: 2000. 
Wilson, Margaret. "Address of the Attorney-General of the First Sitting of the Supreme Court” (1 July 2004). Wellington, New Zealand.

http://www.courtsofnz.govt.nz/from/speeches-and-papers/\#speechpaper-list-firstsitting

Wilson, Margaret, \& Anna Yeatman (eds.). Justice and Identity: Antipodean Practices. Wellington: Bridget Williams Books, 1995.

Wilson, Roy, Chris Cochran, Tommy Honey, \& Gerald Blunt. "Natural Justice." Architecture NZ 2:2010 (March/April): 50-60.

Winters, Glenn R. (ed.). Courthouses and Courtrooms: Selected Readings. Chicago: American Judicature Society, 1972.

\section{Legislation}

Conservation Act 1987

Constitution Act 1986

Crown Minerals Act 1991

District Courts Act 1858

Education Act 1989

Electoral Act 1993

Judicature Act 1908 
Judicature Amendment Act 1957

Judiciature Amendment Act 1980

Judicial Committee Act 1833 (UK)

Ngāti Tūrangitukua Claims Settlement Act 2006

Public Records Act 2005

State-Owned Enterprises Act 1986

Supreme Court Act 2003

Supreme Court Bill 2002

Te Ture Whenua Māori Act 1993

\section{Case law}

Baldick v Jackson (1911) 13 GLR 398

Gifford v Police [1965] NZLR 484

Hoani Te Heuheu Tukino v Aotea District Maori Land Court (1941) AC 308

Hohepa Wi Neera v Bishop of Wellington (1902) 21 NZLR 655

In re the Ninety Mile Beach [1955] NZLR 419

New Zealand Māori Council v Attorney-General [1994] 1 NZLR 513

Nireaha Tamaki v Baker (1901) NZPCC 371; (1902) AC 561 
Nunns v Licensing Control Commission [1967] NZLR 76

$\mathrm{R} v$ Symonds (1847) NZPCC 388

Re the Bed of the Wanganui River [1963] NZLR 673

Smith v McArtbur [1904] AC 389; (1904) NZPCC 323

Tamihana Korokai v Solicitor-General (1912) 32 NZLR 321

Waipapakura v Hempton (1914) 33 NZLR 1065

Wi Parata $v$ The Bishop of Wellington (1877) 3 NZ Jur (NS) SC 72 


\section{Illustration credits}

Abbreviations:

ATL Alexander Turnbull Library, Wellington, New Zealand

NZHPT New Zealand Historic Places Trust

PMcC Paul McCredie, photographer, Wellington, New Zealand

MoJ Ministry of Justice, New Zealand

1. University of Auckland, Early New Zealand Statutes collection.

http://www.enzs.auckland.ac.nz/document?wid=6468\&page=1\&action=null

2. Lithograph by by J. Dickson from a portrait by J Carpenter. ATL Reference

No. C-022-009.

3. Artist unknown. Reproduced in Stacpoole, Colonial Architecture, 33.

4. Philippe Landreville. Supreme Court of Canada Collection. http://www.scc-

csc.gc.ca/

5. High Court of Australia. http://www.hcourt.gov.au/about/the-building

6. MoJ. http://www.courtsofnz.govt.nz/about/system/structure/diagram

7. Photographer unknown. ATL Reference No. PAColl-7985-07.

8. Photographer unknown. Reproduced in Stacpoole, Colonial Architecture, 44.

9. NZHPT.

http://historic.org.nz/TheRegister/RegisterSearch/RegisterResults.aspx?RI

$\underline{\mathrm{D}=7655}$ 
10. Photographer unknown. ATL Reference No. PAColl-0069.

11. Dr Ann McEwan. NZHPT.

http://historic.org.nz/TheRegister/RegisterSearch/RegisterResults.aspx?RI

$\underline{\mathrm{D}=4680}$

12. Aaron Cubis. NZHPT.

http://historic.org.nz/TheRegister/RegisterSearch/RegisterResults.aspx?RI

$\underline{\mathrm{D}=1718}$

13. Bernard Gilpin Haines. ATL Reference No. PA1-f-027-19.

14. Pencil and wash drawing by William Henry Clayton. ATL Reference No. D016-006.

15. Photograph of an engraving from Illustrated New Zealand News, 27 January

1881. ATL Reference No. MNZ-0683-1/4-F.

16. Photographer unknown. ATL Reference No. PAColl-6348-38.

17. Sydney Charles Smith. ATL Reference No. 1/2-047631-G.

18. Photographer unknown. NZHPT.

http://historic.org.nz/TheRegister/RegisterSearch/RegisterResults.aspx?RI

$\underline{\mathrm{D}=489}$

19. Melanie Lovell-Smith. NZHPT.

http://historic.org.nz/TheRegister/RegisterSearch/RegisterResults.aspx?RI

$\underline{\mathrm{D}=321}$

20. Gaze \& Co. ATL Reference No. 1/2-057576-F.

21. Photographer unknown. Alexander ATL Reference No. PA1-O-038-29-2. 
22. Alan Wylde. NZHPT.

http://historic.org.nz/TheRegister/RegisterSearch/RegisterResults.aspx?RI

$\underline{\mathrm{D}=4909}$

23. Ashish Bijwe. NZHPT.

http://historic.org.nz/TheRegister/RegisterSearch/RegisterResults.aspx?RI

$\underline{\mathrm{D}=4207}$

24. David Watt. NZHPT.

http://historic.org.nz/TheRegister/RegisterSearch/RegisterResults.aspx?RI

$\underline{\mathrm{D}=1509}$

25. Nelson Daily Photograph.

http://www.nelsondailyphoto.com/2007/02/nelson-court-house.html

26. Dean Kozanic. http://www.stuff.co.nz/the-press/news/christchurch-

earthquake-2011/5828863/Central-city-venue-chosen-for-jury-trials

27. MoJ.

28. MoJ.

29. Paris Magdalinos Architects, Napier, New Zealand.

http://www.pmarchitects.co.nz/portfolio/public 1.html

30. Opus Architecture, Wellington, New Zealand.

http://www.opusarch.co.nz/projects/justice/timaru-courthouse

31. Paris Magdalinos Architects, Napier, New Zealand.

http://www.pmarchitects.co.nz/portfolio/public 4.html

32. PMcC.

33. Opus Architecture, Wellington, New Zealand.

http://www.opusarch.co.nz/projects/justice/timaru-courthouse 
34. Google maps.

35. Google maps.

36. PMcC.

37. PMcC.

38. PMcC.

39. PMcC.

40. PMcC.

41. Author's photograph.

42. Author's photograph.

43. PMcC.

44. Author's photograph.

45. PMcC.

46. Author's photograph.

47. PMcC.

48. PMcC.

49. PMcC.

50. PMcC.

51. Landcare Research.

http://plantphylogeny.landcareresearch.co.nz/images/treeimages/Agathis a ustralis ovulate cone.jpg

52. Wikipedia user Maksim.

http://en.wikipedia.org/wiki/File:Moire pattern of bricks small.jpg

53. PMcC.

54. PMcC. 
55. PMcC.

56. $\quad \mathrm{PMcC}$.

57. PMcC.

58. Author's photograph.

59. Author's photograph.

60. PMcC

61. PMcC

62. PMcC.

63. PMcC.

64. PMcC.

65. Photographer unknown. ATL, James Joseph Gibbs collection, Reference No. 1/2-005775-F.

66. PMcC.

67. PMcC.

68. PMcC.

69. PMcC.

70. $\quad$ PMcC

71. PMcC.

72. PMcC.

73. Dylan Owen, ATL, Dylan Owen collection, Reference No. PADL-000557.

74. PMcC.

75. Richard Rogers Partnership.

http://www.richardrogers.co.uk/work/all projects/bordeaux law courts/co mpleted 
76. Richard Rogers Partnership.

http://www.richardrogers.co.uk/work/all_projects/bordeaux law courts/co $\underline{\text { mpleted }}$

77. Richard Rogers Partnership.

http://www.richardrogers.co.uk/work/all_projects/bordeaux law courts/co $\underline{\text { mpleted }}$

78. Office of the Governor-General. http://gg.govt.nz/content/speech-throne

79. PMcC.

80. Christchurch Art Gallery, Public Art in Central Christchurch.

http://christchurchartgallery.org.nz/media/uploads/2010 07/PublicArt-

ChCh-1997.pdf

81. Author's photograph.

82. University of Plymouth.

http://www.tech.plym.ac.uk/sme/MATS324/MATS324C2\%20fabrics.htm

83. Land Information New Zealand. http://www.linz.govt.nz/about-

linz/organisation/our-whakapapa/taonga-whakairo

84. Te Papa Tongarewa/Museum of New Zealand.

http://www.teara.govt.nz/en/the-new-zealanders/12/2

85. Unitec Institute of Technology. http://www.unitec.ac.nz/current-

students/maori/unitec-marae/unitec-marae home.cfm

86. NZ Tramping. http://www.nztramping.com/new-zealand-flora/trees-

bigger-than-houses/

87. Melanie Lovell-Smith.

http://www.nzhistory.net.nz/media/photo/pohutukawa-flowers 
88. Forest Flora.

http://www.forestflora.co.nz/Plant $\% 20$ profiles/Metrosideros $\% 20$ fulgens.ht

$\underline{\mathrm{m}}$

89. PMcC

90. Invivo Wines. www.invivo.com

91. Photographer unknown. http://colnect.com/en/stamps/stamp/133590-

Pohutukawa Flowers-Christmas-New Zealand

92. Cartoon by Garrick Tremain. ATL, Garrick Tremain Collection, Reference No. H-671-012. 


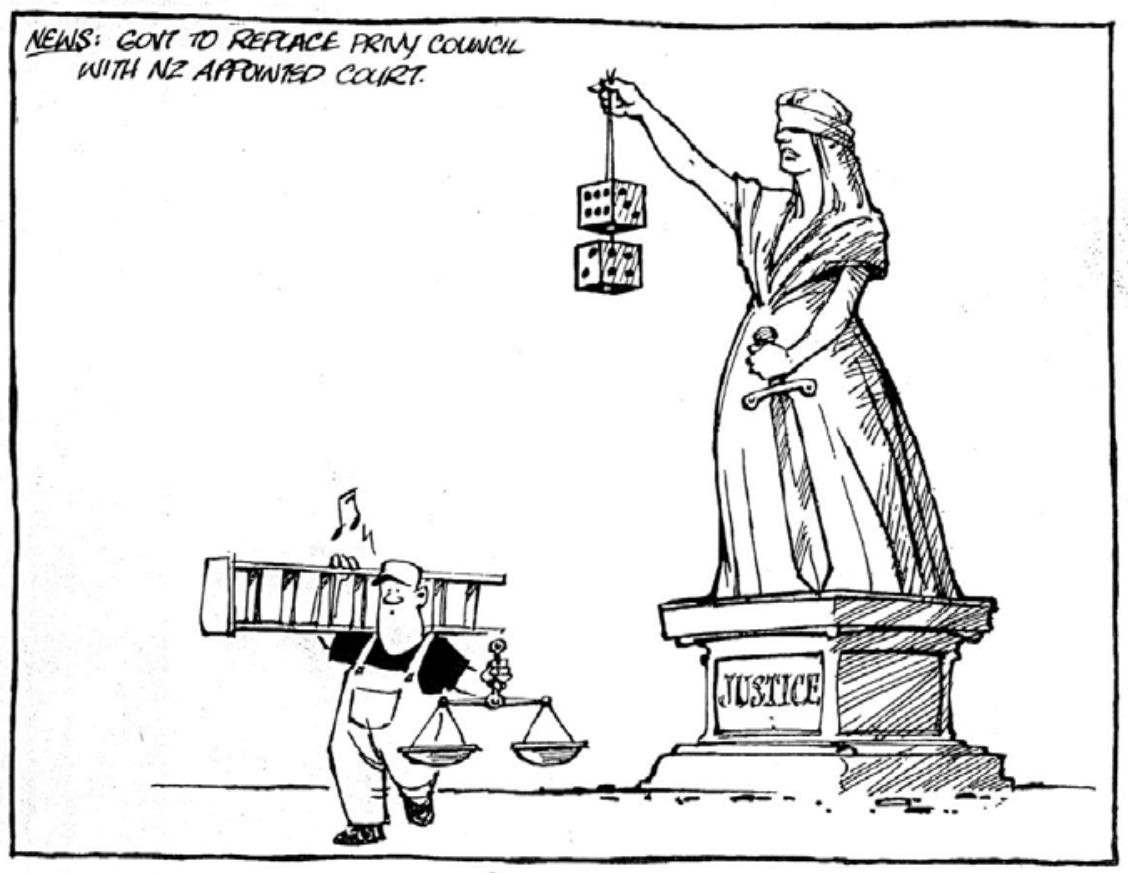

Ill. 92 “Govt to Replace Privy Council with NZ Appointed Court” (16 April 2002) 